\title{
Nutritional interventions to promote post-exercise muscle protein synthesis
}

\author{
Citation for published version (APA):
}

Koopman, R. (2006). Nutritional interventions to promote post-exercise muscle protein synthesis.

[Doctoral Thesis, Maastricht University]. Maastricht University. https://doi.org/10.26481/dis.20060622rk

Document status and date:

Published: 01/01/2006

DOI:

10.26481/dis.20060622rk

Document Version:

Publisher's PDF, also known as Version of record

\section{Please check the document version of this publication:}

- A submitted manuscript is the version of the article upon submission and before peer-review. There can be important differences between the submitted version and the official published version of record.

People interested in the research are advised to contact the author for the final version of the publication, or visit the DOI to the publisher's website.

- The final author version and the galley proof are versions of the publication after peer review.

- The final published version features the final layout of the paper including the volume, issue and page numbers.

Link to publication

\footnotetext{
General rights rights.

- You may freely distribute the URL identifying the publication in the public portal. please follow below link for the End User Agreement:

www.umlib.nl/taverne-license

Take down policy

If you believe that this document breaches copyright please contact us at:

repository@maastrichtuniversity.nl

providing details and we will investigate your claim.
}

Copyright and moral rights for the publications made accessible in the public portal are retained by the authors and/or other copyright owners and it is a condition of accessing publications that users recognise and abide by the legal requirements associated with these

- Users may download and print one copy of any publication from the public portal for the purpose of private study or research.

- You may not further distribute the material or use it for any profit-making activity or commercial gain

If the publication is distributed under the terms of Article $25 \mathrm{fa}$ of the Dutch Copyright Act, indicated by the "Taverne" license above, 


\section{Nutritional interventions to promote post-exercise muscle protein synthesis}




\section{itútin}

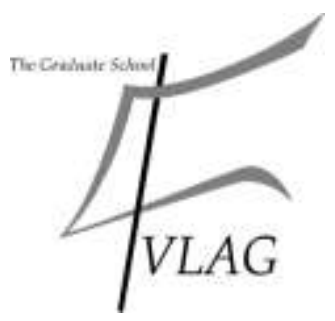

The study presented in this thesis was performed within the Nutrition and Toxicology Research Institute Maastricht (NUTRIM) which participates in the Graduate School VLAG (Food Technology, Agrobiotechnology, Nutrition and Health Sciences), accredited by the Royal Netherlands Academy of Arts and Sciences.

Cover design: René Koopman

Cover photo: Ed van Amsterdam

Layout: René Koopman

Printed by: Datawyse, Universitaire Pers Maastricht

(C) René Koopman, 2006

ISBN xxx-xxx-xxx-xxx 


\section{Nutritional interventions to promote post-exercise muscle protein synthesis}

\section{PROEFSCHRIFT}

ter verkrijging van de graad van doctor aan de Universiteit Maastricht

op gezag van de Rector Magnificus,

Prof. mr. G.P.M.F. Mols

volgens het besluit van het College van Decanen, in het openbaar te verdedigen

op donderdag 22 juni 2006 om 14:00 uur

door

René Koopman

geboren te Rotterdam op 9 februari 1979 


\section{Promotors}

Prof. A.J.M. Wagenmakers

Prof. dr. ir. W.H.M. Saris

\section{Co-promotor}

Dr. L.J.C. van Loon

\section{Beoordelingscommissie}

Prof. dr. A.C. Nieuwenhuijzen Kruseman (voorzitter)

Prof. Y. Boirie (University d'Auvergne, Clermont-Ferrand, France)

Dr. ir. A.K. Kies, R \& D DSM Food Specialties, Delft

Prof. dr. ir. A. Schols

Prof. dr. C.D.A. Stehouwer

The research described in this thesis was supported by grants from Numico Research and DSM Food Specialties.

Financial support by the Dutch Diabetes Association for the publication of this thesis is gratefully acknowledged. Additional support granted by Numico Research and DSM Food Specialties. 


\section{Contents}

\section{Chapter 1}

Introduction

\section{Chapter 2}

A single session of resistance exercise enhances insulin sensitivity for at least $24 \mathrm{~h}$ in healthy men

\section{Chapter 3}

Intramyocellular lipid and glycogen content are reduced following resistance exercise in healthy males

\section{Chapter 4}

Changes in protein metabolism during and following prolonged endurance exercise: effect of nutritional supplements and discrepancies between tracers

\section{Chapter 5}

Combined ingestion of protein and free leucine with carbohydrate increases post-exercise muscle protein synthesis in vivo in male subjects

\section{Chapter 6}

Co-ingestion of protein and leucine stimulates muscle protein synthesis rates to the same extent in young and elderly men

\section{Chapter 7}

The increase in p70-S6K phosphorylation immediately after resistance exercise is muscle fiber-type specific

\section{Chapter 8}

General Discussion

Summary 



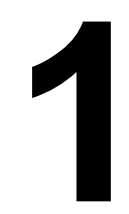

Introduction 
Skeletal muscle is one of the major organs involved in metabolism. It accounts for $\sim 50 \%$ of total body mass and is therefore one of the major contributors to wholebody metabolic rate. In addition, skeletal muscle plays a central role in the regulation of whole-body glucose metabolism. By virtue of its mass, skeletal muscle is the primary tissue responsible for insulin-dependent glucose clearance, accounting for up to $80 \%$ of whole-body glucose uptake following meal ingestion. Aging and diseases like cancer and chronic obstructive pulmonary disease (COPD) are associated with a significant loss of muscle mass. For example, a $20-40 \%$ reduction in fat free mass has been reported in COPD patients. Muscle wasting in aging and these catabolic diseases eventually leads to muscle weakness and major disabilities in day-to-day life. The latter is accompanied by a reduction in physical performance, the loss of functional capacity and an increased likelihood of developing chronic metabolic diseases like obesity, type 2 diabetes and osteoporosis.

Various interventions have been proposed to reduce or reverse the losses of muscle mass and function. It has been suggested that physical activity (i.e. resistance exercise) and nutritional interventions (i.e. protein and amino acids) could represent effective strategies to reduce or counteract the loss of muscle tissue that occurs with aging and disease. In this thesis we focus on the beneficial effects of resistance exercise and the potential of dietary supplementation with carbohydrate, protein and a specific amino acid to enhance muscle protein anabolism.

\section{Resistance exercise}

Resistance exercise or strength training involves a small number of muscle contractions against a heavy load (63). This kind of exercise has been demonstrated to result in an increase in muscle size and strength $(34,93,113)$. Although the metabolic and morphological adaptations resulting from resistance and endurance exercise are quite different, both training methods have been shown to augment whole-body insulin sensitivity $(16,23,29-31,35,55,73,82,92)$. While endurance training can effectively increase mitochondrial density and oxidative capacity (51, 52), resistance training should not be considered as a primary means of training for increasing $\mathrm{VO}_{2} \max$. However, this type of exercise can effectively increase muscular strength, fat free mass and augment physical fitness. The latter is partly due to an increased amount of contractile protein within the muscle (113). This is particularly important in the elderly where the loss of muscle mass and strength are prominent deficits. As such, the American College of Sports Medicine currently recommends strength or resistance training as an important component of an overall fitness program (1).

\section{Resistance exercise and muscle protein synthesis}

Resistance exercise can provoke profound increases in muscle mass, or hypertrophy. However, it generally takes weeks or months before these changes become 
apparent (89). This prolonged time course for hypertrophy is a reflection of the slow turnover rate of muscle proteins. The turnover rate of contractile protein in the fasted state in skeletal muscle, for example, is as low as $1 \%$ per day $(7,77,105)$. Hypertrophy can only occur when protein synthesis is exceeding protein breakdown for an extended period. In conclusion, it is the balance between muscle protein synthesis and breakdown rates that determines net protein balance and the rate of net protein gain (89).

Resistance exercise can effectively stimulate muscle protein synthesis $(21,68,69$, 84). It has been shown that after a single session of resistance exercise, muscle protein synthesis is rapidly stimulated within 2 to $4 \mathrm{~h}$ (84). Moreover, the stimulation of protein synthesis has been reported to last for at least $24 \mathrm{~h}(21,68)$, up to $48 \mathrm{~h}(84)$. The increase in muscle protein synthesis or fractional synthetic rate (FSR), can be largely attributed to an increase in myofibrillar protein synthesis rates. Proteins, likely to be upregulated following resistance exercise are most likely myosin heavy chain (MHC) and actin, since those proteins are most abundant in skeletal muscle. This is supported by observations showing that synthesis rates of MHC are increased after a single resistance exercise session $(11,112,119)$. Interestingly, muscle protein breakdown is also stimulated following resistance exercise; although, to a lesser extent than protein synthesis. The result is an increased net muscle-protein balance that persist up to $48 \mathrm{~h}$ (84). On the other hand, net muscle protein balance is negative in the absence of nutrient intake, indicating that the muscle remains in a catabolic state. Therefore, muscle hypertrophy requires the interaction of exercise and nutrition, which will be further discussed in chapter 1.4.

In addition to the acute effects of resistance exercise on muscle protein synthesis rates, prolonged resistance exercise training results in an elevated resting mixed muscle protein FSR $(83,85)$. This training induced elevation in muscle protein turnover indicates that the processes of protein synthesis and degradation are both increased. The latter may indicate that a more rapid protein remodeling is taking place (83).

\section{Muscle protein synthesis}

The primary determinant of skeletal muscle size attained during resistance training is the external load that is applied. Several animal models have shown that increased loading results in an increased muscle mass and protein content per muscle (6, 10, 90). Increased loading enhances muscle protein synthesis and breakdown and this training induced rise in muscle protein turnover leads to a more rapid protein remodeling (83).

Factors that lead to muscle hypertrophy are: muscle cell stretch $(56,70)$, increases in intracellular calcium (56), as well as exercise-induced increases in circulating and locally produced growth-factors such as insulin-like growth factor-1 (IGF-1; 42) and muscle growth factor (MGF; 47, 49). An acute bout of resistance exercise has been shown to activate transcription factors like Myo-D and myogenin (115), and to increase the rate of mRNA formation encoding for myosin heavy chain (66, 
115). However, interestingly, changes in the rate of protein synthesis occur before changes in mRNA accumulation (111). Therefore, activation of protein synthesis must be controlled by a post-transcriptional mechanism (64). The posttranscriptional regulation of protein synthesis involves mRNA translation initiation, elongation, termination and post-translational modification. The initiation of mRNA translation is thought to be most important for the overall control of muscle protein synthesis (14).

\section{Translation initiation}

The initiation of mRNA translation is a complex multi-step process requiring more than a dozen eukaryotic initiation factors (eIFs) $(59,81)$. At least two steps in the initiation pathway are subject to regulation in vivo: 1) binding of initiator methionyltRNA (met-tRNA) to the $40 \mathrm{~S}$ ribosomal subunit, and 2) binding of mRNA to the $43 \mathrm{~S}$ pre-initiation complex (2). In the first step, met-tRNA binds to the $40 \mathrm{~S}$ ribosomal subunit as a ternary complex with eIF2 and GTP. A second initiation factor, eIF2B, mediates guanine nucleotide exchange on eIF2 (figure 1.1). Inhibition of eIF2B activity results in a decrease in the amount of eIF2.GTP available to form the ternary complex, thereby limiting translation initiation. The activity of eIF2B is reciprocally regulated in part by phosphorylation of the $\alpha^{-}$ subunit of eIF2, as it converts eIF2 from a substrate to a competitive inhibitor of eIF2B (60).

Another potential rate-controlling step in the process of translation initiation involves the recognition and unwinding of the mRNA to allow binding to the $40 \mathrm{~S}$ ribosome (2). This step requires a group of proteins referred to as eIF4F (figure 1.1), which is a multi-subunit complex (consisting of both eIF4E and eIF4G). The eIF4F complex collectively serves to recognize, unfold and guide the mRNA to the $43 \mathrm{~S}$ pre-initiation complex (81). Modulation of eIF4E availability for binding eIF4G and forming the active eIF4F complex can alter translation initiation. The availability of eIF4E for eIF4F complex formation appears to be regulated in part by 4E-BP1, which compete with eIF4G for binding eIF4E (46), and is able to sequester eIF4E into an inactive complex. The binding of 4E-BP1 to eIF4E is regulated by phosphorylation of 4E-BP1, with increased phosphorylation of the protein causing a decrease in the affinity of 4E-BP1 for eIF4E.

\section{Intracellular signaling pathways that regulate translation initiation}

It has been shown that the phosphatidylinositol-3 kinase (PI-3 kinase)/mammalian target of rapamycin (mTOR) signal transduction pathway plays a major role in the regulation of translation initiation. This signaling pathway includes several protein kinases, including PI-3 kinase, protein kinase B (PKB, or Akt), mTOR and p70/p85 ribosomal protein S6 protein kinase (S6K1). Akt, downstream of PI-3 kinase, phosphorylates and inactivates another protein kinase, glycogen synthase kinase (GSK-3). Consequently GSK-3 phosphorylates eIF2B, resulting in inhibition of its guanine nucleotide exchange activity, thereby increasing protein 
synthesis rates (figure 1.1). In addition to GSK-3, Akt also phosphorylates mTOR on Ser 2448 , which subsequently phosphorylates and activates 4E-BP1 and S6K1. This allows the eIF4F complex formation and the activation of ribosomal protein S6, resulting in enhanced mRNA translation (figure 1.1).

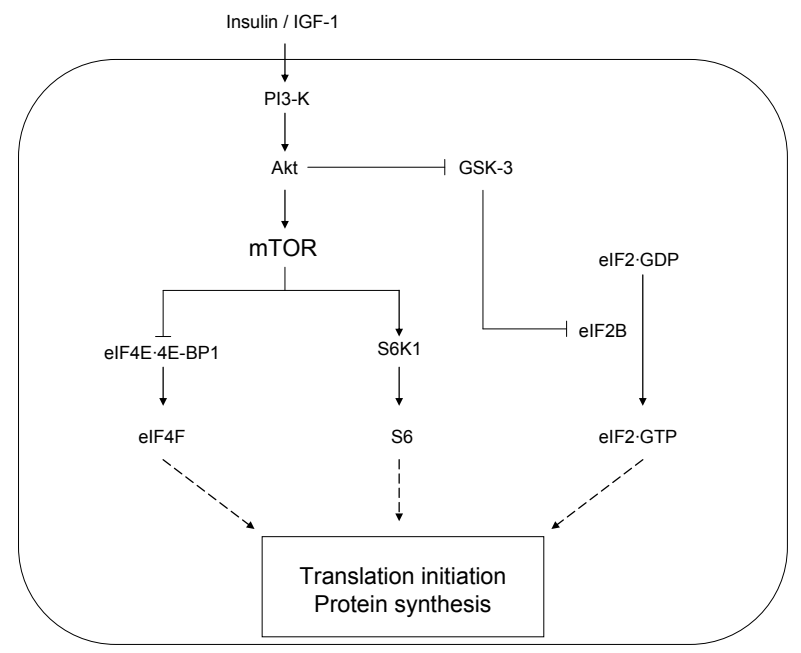

Figure 1.1 Intracellular signaling and protein signaling. Details of the individual steps are discussed in the text. PI3-K, phosphatidylinositol-3 kinase; Akt, protein kinase B; mTOR, mammalian target of rapamycin protein kinase; eIF4E, eukaryotic initiation factor 4E; 4E-BP1, eIF4E binding protein 1; S6K1; p70/p85 ribosomal protein S6 protein kinase; eIF4F, eukaryotic initiation factor 4F; S6, ribosomal protein S6; GSK-3, glycogen synthase kinase 3; eIF2B, eukaryotic initiation factor 2B; eIF2.GDP, inactive eukaryotic initiation factor 2; eIF2·GTP, activated eukaryotic initiation factor 2.

Chronic overloading of the plantaris muscle in rodents has been shown to increase phosphorylation of $\mathrm{Akt} / \mathrm{PKB}$ and proteins downstream of mTOR, such as $4 \mathrm{E}$ BP1 and S6K1 (10). In addition, increased phosphorylation of Ser ${ }^{2448}$ on mTOR after overload has been reported in rats (90). Moreover, in other animal studies phosphorylation of both 4E-BP1 and S6K1 has been shown to be enhanced in response to muscle loading $(6,10,75)$. However few studies have examined the impact of exercise on translation initiation factors in humans in vivo. A recent study in humans investigated the effects of a single session of resistance exercise on S6K1 activation (57). Although phosphorylation of S6K1 was increased following exercise, S6K1 activity was unaltered, as evidenced by unchanged S6 phosphorylation. These data indicate that a single session of resistance exercise does not fully activate S6K1. Interestingly, Karlsson et al. (15) showed that postexercise ingestion of branched chain amino acids has a striking effect on S6K1 phosphorylation, which was evident by site-specific phosphorylation at $\mathrm{Thr}^{389}$. These data indicate that intake of protein/amino acids is needed to fully activate skeletal muscle translation initiation. 


\section{Measuring protein synthesis}

Our knowledge of the regulation of protein metabolism at the whole-body, muscle and organ levels in various physiological conditions is based on direct and indirect measurements of protein synthesis and breakdown, and exchange rates of amino acids and amino acid tracers between tissues (109). In the studies that are described in this thesis we used amino acid tracers to study the effect of several exercise and nutritional interventions on whole-body and muscle protein turnover.

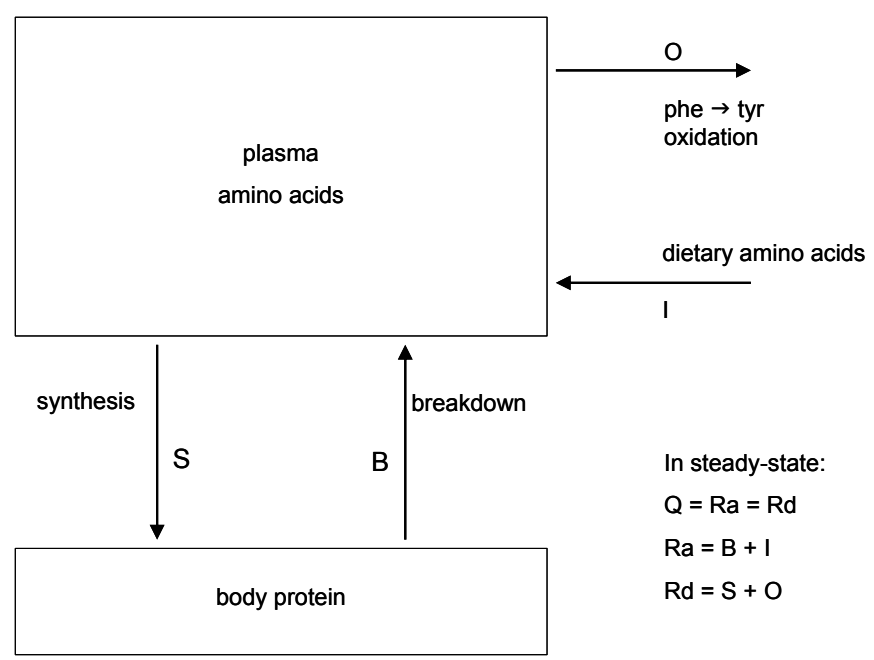

Figure 1.2 General model of protein metabolism used in the whole-body methods. Q, whole-body amino acid turnover or flux; Ra, rate of appearance in the plasma free amino acid pool; Rd, rate of disappearance from the plasma free amino acid pool; phe, phenylalanine; tyr, tyrosine. Adapted from Wagenmakers (109).

\section{Measuring whole-body protein turnover}

Stable isotope tracers are widely used in biomedicine to study metabolic pathways in vivo, because they are functionally identical to the compound of interest (tracee), but distinct in some physical characteristics that enable their precise detection (116). Calculation of substrate kinetics traditionally measures the rate of appearance $(\mathrm{Ra})$ which in steady state conditions equals the rate of disappearance (Rd) of the substrate (=flux). In a single pool model it is assumed that the infusion of tracer, sampling, and Ra of substrate occurs from a single, homogenous, instantly mixing pool (109). In metabolic studies, the blood compartment is usually viewed as a single pool, which implicates that blood sampling is allowed for the calculation of whole-body flux $(109,116)$. In this model the rate of disappearance of amino acids from the blood compartment equals the rate of oxidation + protein synthesis, whereas the rate of appearance of amino acids equals the rate of protein breakdown + the rate of appearance of meal protein from the gut (figure 1.2) (109). 
The use of the (whole-body) tracer balance methodology to investigate the effect of post-exercise nutrition on protein metabolism has some important limitations, as it does not allow the direct measurement of muscle protein synthesis rates. As such, it does not provide information on the contribution of individual tissues to protein metabolism, their response to nutritional and/or exercise intervention and it does not enable the discrimination between active and inactive muscle.

\section{Measuring muscle protein synthesis}

To circumvent the limitation of whole-body tracer methodology, methods were introduced to measure tissue or protein-specific synthesis rates; the amino acid tracer incorporation method. In most of these studies the amino acid tracer is provided by a continuous intravenous infusion until a steady state is obtained in the precursor pool for protein synthesis. Repeated muscle samples are then taken at steady-state. The protein is precipitated from the biopsy samples, hydrolyzed and the amino acids, after derivatization are analyzed for tracer enrichment using gas chromatography-mass spectrometry (GC-MS) or gas chromatography-isotope ratio mass spectrometry (GC-IRMS) methodology. The rise in tracer enrichment in the protein-bound amino acid fraction, over a given sampling time, is divided by the steady-state tracer enrichment in the precursor pool to give the fractional synthetic rate (FSR) of the protein, which is the percentage of the existing pool that has been synthesized over that time period (109). Although there has been a lot of discussion in the literature on which amino acid pool represents the best reflection of the precursor pool for protein synthesis during continuous-infusion studies, the intracellular amino acyl-tRNA is generally regarded to be the true protein synthesis precursor pool (109). However, due to the large muscle sample size that is required to make an estimate of the enrichment in the amino acyl-tRNA pool and the inherent analytical complexity of such measurements, the plasma and free muscle amino acid enrichments are generally used as surrogates to provide an estimate of the lower boundary (based on plasma precursor enrichments) and the higher boundary (based on intracellular muscle precursor enrichments) for the true fractional synthetic rate of mixed muscle proteins.

\section{Nutrition and muscle protein synthesis}

Physical activity is the most powerful stimulus to promote net muscle protein anabolism. After a single bout of resistance exercise, muscle protein synthesis and degradation rates are elevated. As a result, net muscle protein balance will actually remain negative in the absence of food intake. Skeletal muscle hypertrophy can only take place when food is ingested during the early phases of post-exercise recovery (32). Consequently, the combined ingestion of carbohydrate and protein/amino acids during recovery from exercise forms an effective strategy to stimulate muscle protein synthesis, inhibit protein degradation and, as such, to obtain a positive muscle protein balance by optimizing circulating insulin and amino acid concentrations. 


\section{Carbohydrate}

The ingestion of glucose during the post-exercise recovery phase has been shown to significantly increase circulating plasma insulin levels $(62,95,102,103)$. The latter has been shown to result in a decrease in urinary 3-methylhistidine and urea excretion, suggesting that protein degradation is reduced (95). However, muscle protein synthesis rates are not affected following carbohydrate ingestion $(17,95)$. Although carbohydrate ingestion improves net leg amino acid balance compared with water or placebo intake, the net balance remains negative (17). The effects of carbohydrate supplementation on protein metabolism can be in part attributed to the increase in circulating insulin. The elevation of plasma insulin levels results in an increase in net muscle protein anabolism in vivo in humans (42, 45, 53). However, insulin should not be regarded as a primary regulator of muscle protein synthesis rates as insulin levels exert only a modest effect on muscle protein synthesis in the absence of elevated amino acid concentrations (8). These observations are further supported by measurements in rats, showing that increased circulating insulin concentrations alone (induced by glucose supplementation) do not stimulate translation initiation post-exercise in rats (44). In addition, a nutritionally complete meal was shown to be more effective than feeding carbohydrate alone for post-exercise stimulation of protein synthesis (44). It is therefore suggested that most probably the protein in the diet is necessary for full stimulation of translation initiation and thus protein synthesis in skeletal muscle during exercise recovery.

\section{Protein and amino acids}

Amino acids have more metabolic roles than to merely serve as the building blocks of proteins. In addition, amino acids have been shown to induce the secretion of insulin, glucagon, growth hormone, and IGF-1 (37). The infusion of free amino acids in vivo in humans was shown to result in a significant increase in plasma insulin levels (38-41). More recently, reports from our laboratory show that coingestion of a protein hydrolysate and free leucine and phenylalanine with carbohydrate effectively increases the plasma insulin response in type 2 diabetes patients (101), healthy controls (104) and endurance trained athletes (102, 103). Amino acids, and leucine in particular, can act as potent stimuli for the secretion of insulin from the pancreatic $\beta$-cell. The various mechanisms by which amino acids promote and/or enhance insulin secretion are diverse and have not yet been fully elucidated (79). Similar to glucose mediated insulin secretion (28), intracellular catabolism of the metabolizable amino acids will increase substrate availability for the tricarboxylic acid (TCA) cycle. Increased TCA cycle activity and oxidative phosphorylation will result in an increased ATP/ADP ratio, which will lead to the closing of ATP-sensitive $\mathrm{K}^{+}$channels. The latter will lead to the depolarization of the plasma membrane, thereby opening up voltage activated $\mathrm{Ca}^{2+}$-channels, resulting in $\mathrm{Ca}^{2+}$-activated insulin exocytosis. Leucine-induced insulin secretion is mediated by its oxidative decarboxylation as well as by its ability to allosterically activate glutamate dehydrogenase $(79,96,117)$. Both the generation of acetyl-CoA 
and $\alpha$-ketoglutarate are needed for leucine to fully stimulate mitochondrial activity in the pancreatic $\beta$-cell. The metabolically linked secondary signals that subsequently lead to insulin exocytosis remain to be established, and also seem responsible for the leucine-induced activation of the mTOR signaling pathway $(100,117)$.

There is a substantial amount of evidence that supplementation with protein/amino acids can effectively stimulate muscle protein synthesis rates. Biolo et al. (9) demonstrated that hyperaminoacidemia, resulting from intravenous infusion of amino acids, increases post-exercise muscle protein synthesis rates and prevent the exercise-induced increase in protein degradation. Moreover, amino acid infusion in the fasted state, without preceding (resistance) exercise, rapidly increased muscle protein synthesis (105). Since intravenous infusion of free amino acids is not a practical method for amino acid delivery, oral ingestion of protein and/or amino acids has been studied intensively. The oral ingestion of a large amount $(30-40 \mathrm{~g})$ of amino acids after exercise effectively stimulates muscle protein synthesis (99). Moreover, ingestion of a small amount of essential amino acids (EAAs) with and without carbohydrates has also been shown to increase post-exercise protein synthesis and improve net protein balance $(18,72,87)$. Thus, post-exercise amino acid ingestion represents an effective method to maximize the anabolic effect of exercise. However, ingestion of only a small amount (6 g) of EAA $1 \mathrm{~h}$ and $2 \mathrm{~h}$ post-exercise resulted in a positive net protein balance for only two hours, after which net protein balance over the muscle became negative (18). This indicates that amino acid and/or energy delivery was not sufficient to maintain an anabolic state (enhanced protein synthesis).

The precise mechanisms responsible for this amino acid-induced anabolic response have not yet been established. Amino acids play an important role in the control of mRNA translation and thus protein synthesis in skeletal muscle (58). Increased amino acid availability, particularly the branched-chain amino acid leucine, has been shown to activate several key-factors (mTOR, S6K1) of the mTOR signal transduction pathway, thereby increasing the rate of mRNA translation (61).

\section{Leucine}

The role of leucine as a regulator of protein metabolism has been studied extensively (43). In the 1970s, a number of laboratories performed in vitro investigations of the factors that control protein turnover in tissues $(19,65,74)$. These studies showed that high concentrations of all amino acids stimulated protein synthesis and inhibited protein degradation. In particular, it was shown in isolated diaphragm muscle, that leucine alone could effectively stimulate protein synthesis (19). This group of studies, from several laboratories, initiated a continuing series of investigations into the role of leucine in the control of tissue protein mass, its mechanism of action, and its possible value for enhancing muscle protein deposition in healthy subjects or moderating muscle protein loss in catabolic states in patients. 
In general, most animal studies support the findings by Buse and Reid (19) and report that leucine inhibits muscle protein breakdown and stimulates muscle protein synthesis. For example, Anthony et al. $(3,4)$ have reported a direct, stimulating effect of leucine ingestion on muscle protein synthesis in rodents. In line with those data, the same group showed that leucine supplementation enhances protein synthesis in skeletal muscle from diabetic rats through insulinindependent mechanisms (5). These studies have increased the understanding of the mechanisms of nutritional regulation of protein synthesis at the molecular level and indicate that leucine ingestion could stimulate muscle anabolism in several ways, as it can further increase plasma insulin concentrations and also directly stimulate protein synthesis. Leucine has the ability to function as a nutritional signaling molecule that modulates muscle protein synthesis and/or breakdown following food intake. The stimulatory effect of leucine on protein synthesis occurs at the level of translation initiation and involves signaling through mTOR $(61,86)$, which is thought to serve as a convergence point for leucine- and insulin-mediated effects on translation initiation $(61,86)$. In addition, leucine has been shown to have the potential to affect muscle protein metabolism by decreasing the rate of protein degradation (78), most likely via an increase in circulating insulin, and phosphorylation of key proteins involved in the regulation of protein synthesis (57, 67, 86).

Though most in vitro and in vivo animal studies report that leucine administration can inhibit protein breakdown and stimulate protein synthesis, most in vivo human studies report that leucine and/or BCAA administration reduces muscle protein breakdown, without stimulating muscle protein synthesis (71). The apparent discrepancy between observations in humans and animal studies remains to be elucidated. Maximal rates of protein synthesis rates during post-exercise recovery probably require both leucine and insulin signaling and the anabolic signal of resistance exercise. However, under normal in vivo conditions in humans it is impossible to discriminate between the effects of leucine and insulin and resistance exercise (IGF-1 and MGF) on muscle protein synthesis.

In conclusion, due to anabolic properties of insulin and amino acids (leucine in particular), it has been suggested that a dietary supplement containing free leucine, protein and carbohydrate could be an effective tool to further increase postexercise muscle protein synthesis and/or to inhibit protein degradation.

\section{Aging}

The progressive aging of our population imposes a major threat to welfare in the Western society. Population demographics in the Netherlands show that by 2025 more than $20 \%$ of the entire Dutch population will be aged 65 years or older (91). This aging of our society is responsible for a major increase in population morbidity, which will put an increasing demand on our health care system. The increased morbidity in the elderly is associated with the progressive decline in skeletal muscle mass and function. This process of age-related loss of muscle mass and function, or sarcopenia, has substantial health consequences, as it is associated 
with decreased basal metabolic rate, increased body fatness, loss of bone mass and reduced strength and functional capacity. Sarcopenia is facilitated by a combination of factors, which include a more sedentary lifestyle and sub-optimal diet. The agerelated changes in skeletal muscle mass are attributed to a disruption in the regulation of muscle protein turnover, which results in a chronic imbalance between muscle protein synthesis and degradation.

\section{Aging and muscle function}

It has been reported that both muscle cross-sectional area and fiber numbers decreased from as early as the fourth decade of life. Short et al. $(97,98)$ measured the cross-sectional area of muscle in the mid-thigh using computed tomography imaging in healthy human subjects (18 to $88 \mathrm{y}$ ) and observed an age-related decrease in muscle area starting from the fourth decade of life. In addition, a parallel decrease in muscle strength (knee extension) occurred with the decrease in muscle mass. Accordingly, data from our laboratory shows a similar an age-related decrease in muscle strength (figure 1.3, L. Verdijk, unpublished observations). Maximal oxygen uptake is another physical performance related factor which has been shown to decline with aging (97). As a result, the muscles of older individuals are thought to fatigue faster than those of young adults.

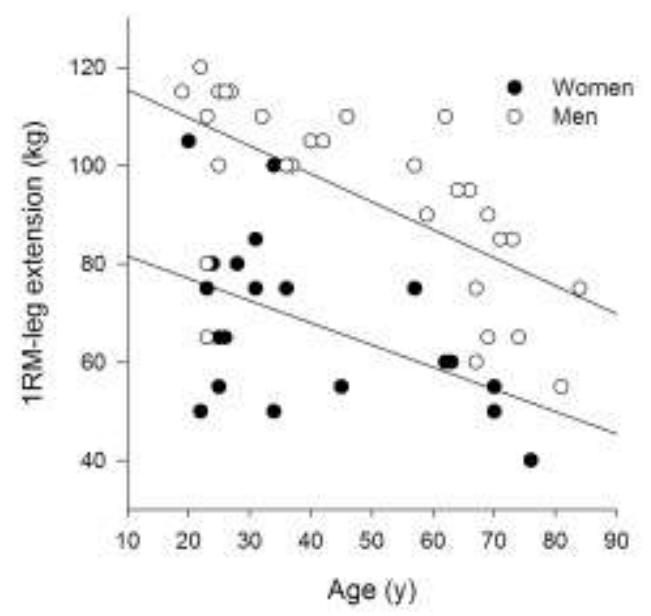

Figure 1.3 Age-related decrease in knee extensor strength as observed in our laboratory. Knee extensor strength was determined on a leg-extentions machine. 1RM, one-repetition maximum or maximal strength.

The observed decrease in muscle mass and muscle strength with aging, in combination with a reduced endurance capacity, is linked to reduced levels of physical activity (76), which results in a decrease in total energy expenditure in older persons. The latter is likely to attribute to an increased prevalence of obesity, especially abdominal fat accumulation. Such alterations in body composition can 
cause insulin resistance and contribute to the development of type 2 diabetes, hyperlipidemia, and hypertension. The combined effect of these metabolic abnormalities is increased cardiovascular and other morbidities (76).

\section{Aging and muscle protein turnover}

The age-related changes in skeletal muscle mass are attributed to a disturbance in the regulation of muscle protein turnover, which results in a chronic imbalance between muscle protein synthesis and degradation. The concept of aging is strongly associated with a decrease in protein synthesis, including changes in genome integrity and gene expression (54), and in translation and post-translational modifications of proteins (88). Recently, it has been shown that muscles of elderly humans have significantly lower amounts of total mTOR, S6K1 and eIF2B, all keyfactors in the regulation of translation initiation (24). Many studies have reported either similar (80, 106-108), or reduced $(7,50,94,112,113,118,119)$ skeletal muscle protein synthesis rates in the elderly compared with young adults. More specifically, the synthesis rates of myofibrillar proteins (112), but not of sarcoplasmic proteins (7) have been shown to be reduced in the elderly compared with young adults. The synthesis of myosin heavy chain was dramatically reduced (7), without any change in its rate of transcription (110). In addition to the reduced MHC synthesis, aging is also characterized by a reduced rate of mitochondrial protein synthesis, which may contribute to the depressed aerobic capacity and muscle performance (94). Restoring the balance between protein synthesis and breakdown should form the main therapeutic target in intervention programs designed to improve muscle mass and function in the elderly.

\section{Interventions to improve muscle protein synthesis in the elderly}

There is substantial evidence that the muscle protein synthesis rate is responsive to exercise (89). In studies performed in young and aged persons, resistance exercise (50) and endurance exercise (97) stimulate the synthesis rate of mixed muscle proteins. Resistance exercise training mainly affects muscle strength and muscle mass and can increase specific muscle proteins, such as MHC proteins, in the elderly (50). In contrast, endurance exercise improves many metabolic functions, including insulin-induced glucose disposal and mitochondrial function, which is likely to be mediated by changes in specific proteins/enzymes (15). The specific adaptations that occur depend on the frequency, intensity and the duration of the exercise regimen, as it has been shown that only modest increases in strength are achieved by elderly subjects when exercise intensity is low (33).

In addition to exercise, it has been hypothesized that the ingestion of sufficient amounts of protein or specific mixtures of amino acids can effectively increase the anabolic response in older individuals. In accordance, infusion of amino acids has been shown to increase muscle protein synthesis in the elderly (105). However, intravenous infusion of amino acids is not a physiologic route for amino acid delivery, as it circumvents both intestinal absorption and first-pass splanchnic 
processing. Interestingly, it has been shown that protein digestion rates can differentially affect the anabolic response in young and older adults (25). Slowly absorped protein (casein) stimulates protein anabolism in the young (12), whereas faster absorped proteins (whey protein) favor anabolism in the elderly (25). In addition, a percentage of the ingested amino acids will not be made available for muscle protein synthesis due to utilization in the splanchnic tissues. The latter has been suggested to increase with age (13, 107). Nevertheless, Volpi et al. (107) demonstrated that despite a greater first-pass extraction by the gut and liver of orally administered amino acids, the amino acid-induced muscle protein anabolism in older subjects is not different from that of younger individuals.

In contrast to these finding, there are indications that the anabolic response to mixed meal, consisting of carbohydrate and protein (and fat), is substantially blunted in the elderly. For example, most interventions using nutritional supplements to attenuate muscle loss in older individuals were unsuccessful in humans $(20,36,114)$. However, Esmarck et al. (32) showed that in the elderly the timing of protein ingestion following resistance exercise is crucial, as immediately post-exercise supplement ingestion resulted in significantly greater gains than when the supplement was ingested after several hours of recovery. Volpi et al. (106) reported a blunted anabolic response in older individuals to the combined ingestion of glucose and essential amino acids. The latter was confirmed using the hyperinsulinemic, hyperaminoacidemic clamp technique showing an impaired activation of S6K1 as a potential mechanism for the attenuated protein synthetic response in the elderly (48).

Interestingly, recent studies in rodent have suggested a possible role for oral leucine supplementation to restore normal postprandial anabolism in aged animals $(26,27)$. When supplemented with leucine, muscle protein synthesis in old rats was stimulated and similar to that observed in mature rats. Therefore, it was concluded that meal supplementation with leucine was sufficient to restore postprandial stimulation of muscle protein synthesis (27) and inhibition of proteasomedependent proteolysis (22) in old rats. Whether leucine supplementation can effectively increase muscle protein synthesis and net muscle protein balance and quality under normal physiological conditions in humans remains to be established.

\section{Outline of this thesis}

This thesis describes a series of studies that investigate the effects of exercise and nutrition on muscle protein synthesis, substrate utilization and insulin sensitivity. In chapter 2, we first describe a study about the acute effects of a single session of resistance exercise on whole-body insulin sensitivity. Chapter $\mathbf{3}$ describes a study in which we focused on the use of intramyocellular substrate sources during a single session of resistance exercise. Based on the observed changes in muscle lipid and glycogen content we discuss possible interactions with the observed improvement in insulin sensitivity following such an exercise bout. In chapter 4, we describe the use of different amino acid tracers to determine whole-body protein metabolism and discuss which amino acid should be preferentially used as 
a tracer in metabolic research. In addition, we investigated the effects of the ingestion of different nutritional supplements on whole-body protein metabolism. Chapters 5 and $\mathbf{6}$ describe the effects of amino acid and/or protein ingestion on muscle protein synthesis. In chapter 5, we investigated the effects of the ingestion of carbohydrate, protein and leucine on skeletal muscle protein synthesis rates after resistance exercise in young healthy males. Chapter $\mathbf{6}$ describes a study in which we compared muscle protein synthesis following activities of daily living between young and elderly subjects while ingesting carbohydrates. In addition we investigated the effects of the combined ingestion of protein and leucine with carbohydrate on muscle protein synthesis rates in the young and the elderly. In chapter 7, we provide information on the effect of a single session of resistance exercise on the phosphorylation status of several proteins that are involved in the regulation of muscle protein synthesis and investigate whether changes in phosphorylation are muscle fiber-type specific. Finally, chapter $\mathbf{8}$ discusses the results of the above described studies and provides an overview of the main conclusions. Based on these conclusions the practical implications of the performed research are discussed and subsequent aims for future research are provided. 


\section{References}

1. American College of Sports Medicine Position Stand. The recommended quantity and quality of exercise for developing and maintaining cardiorespiratory and muscular fitness, and flexibility in healthy adults. Med Sci Sports Exerc 30: 975-991, 1998.

2. Anthony JC, Anthony TG, Kimball SR, and Jefferson LS. Signaling pathways involved in translational control of protein synthesis in skeletal muscle by leucine. J Nutr 131: 856S-860S, 2001.

3. Anthony JC, Anthony TG, Kimball SR, Vary TC, and Jefferson LS. Orally administered leucine stimulates protein synthesis in skeletal muscle of postabsorptive rats in association with increased eIF4F formation. J Nutr 130: 139-145, 2000.

4. Anthony JC, Anthony TG, and Layman DK. Leucine supplementation enhances skeletal muscle recovery in rats following exercise. J Nutr 129: 1102-1106, 1999.

5. Anthony JC, Reiter AK, Anthony TG, Crozier SJ, Lang CH, MacLean DA, Kimball SR, and Jefferson LS. Orally Administered Leucine Enhances Protein Synthesis in Skeletal Muscle of Diabetic Rats in the Absence of Increases in 4E-BP1 or S6K1 Phosphorylation. Diabetes 51: 928-936, 2002.

6. Baar K and Esser K. Phosphorylation of p70(S6k) correlates with increased skeletal muscle mass following resistance exercise. Am J Physiol 276: C120-127, 1999.

7. Balagopal P, Rooyackers OE, Adey DB, Ades PA, and Nair KS. Effects of aging on in vivo synthesis of skeletal muscle myosin heavy-chain and sarcoplasmic protein in humans. Am J Physiol 273: E790-800, 1997.

8. Biolo G, Declan Fleming RY, and Wolfe RR. Physiologic hyperinsulinemia stimulates protein synthesis and enhances transport of selected amino acids in human skeletal muscle. J Clin Invest 95: 811-819, 1995.

9. Biolo G, Tipton KD, Klein S, and Wolfe RR. An abundant supply of amino acids enhances the metabolic effect of exercise on muscle protein. Am J Physiol 273: E122129, 1997.

10. Bodine SC, Stitt TN, Gonzalez M, Kline WO, Stover GL, Bauerlein R, Zlotchenko E, Scrimgeour A, Lawrence JC, Glass DJ, and Yancopoulos GD. Akt/mTOR pathway is a crucial regulator of skeletal muscle hypertrophy and can prevent muscle atrophy in vivo. Nat Cell Biol 3: 1014-1019, 2001.

11. Bohe J, Low JF, Wolfe RR, and Rennie MJ. Latency and duration of stimulation of human muscle protein synthesis during continuous infusion of amino acids. J Physiol 532: 575-579, 2001.

12. Boirie Y, Dangin M, Gachon P, Vasson MP, Maubois JL, and Beaufrere B. Slow and fast dietary proteins differently modulate postprandial protein accretion. Proc Natl Acad Sci U S A 94: 14930-14935, 1997.

13. Boirie Y, Gachon P, and Beaufrere B. Splanchnic and whole-body leucine kinetics in young and elderly men. Am J Clin Nutr 65: 489-495, 1997.

14. Bolster DR, Kimball SR, and Jefferson LS. Translational control mechanisms modulate skeletal muscle gene expression during hypertrophy. Exerc Sport Sci Rev 31: 111-116, 2003.

15. Booth FW, Chakravarthy MV, and Spangenburg EE. Exercise and gene expression: physiological regulation of the human genome through physical activity. J Physiol 543: 399-411, 2002.

16. Borghouts LB, Backx K, Mensink MF, and Keizer HA. Effect of training intensity on insulin sensitivity as evaluated by insulin tolerance test. Eur J Appl Physiol Occup Physiol 80: 461-466, 1999. 
17. Borsheim E, Cree MG, Tipton KD, Elliott TA, Aarsland A, and Wolfe RR. Effect of carbohydrate intake on net muscle protein synthesis during recovery from resistance exercise. J Appl Physiol 96: 674-678, 2004.

18. Borsheim E, Tipton KD, Wolf SE, and Wolfe RR. Essential amino acids and muscle protein recovery from resistance exercise. Am J Physiol Endocrinol Metab 283: E648657, 2002.

19. Buse MG and Reid SS. Leucine. A possible regulator of protein turnover in muscle. J Clin Invest 56: 1250-1261, 1975.

20. Campbell WW, Crim MC, Young VR, Joseph LJ, and Evans WJ. Effects of resistance training and dietary protein intake on protein metabolism in older adults. Am J Physiol 268: E1143-1153, 1995.

21. Chesley A, MacDougall JD, Tarnopolsky MA, Atkinson SA, and Smith K. Changes in human muscle protein synthesis after resistance exercise. J Appl Physiol 73: 1383-1388, 1992.

22. Combaret L, Dardevet D, Rieu I, Pouch MN, Bechet D, Taillandier D, Grizard J, and Attaix D. A leucine-supplemented diet restores the defective postprandial inhibition of proteasome-dependent proteolysis in aged rat skeletal muscle. J Physiol, 2005.

23. Craig BW, Everhart J, and Brown R. The influence of high-resistance training on glucose tolerance in young and elderly subjects. Mech Ageing Dev 49: 147-157, 1989.

24. Cuthbertson D, Smith K, Babraj J, Leese G, Waddell T, Atherton P, Wackerhage H, Taylor PM, and Rennie MJ. Anabolic signaling deficits underlie amino acid resistance of wasting, aging muscle. Faseb J 19: 422-424, 2005.

25. Dangin M, Guillet C, Garcia-Rodenas C, Gachon P, Bouteloup-Demange C, ReiffersMagnani K, Fauquant J, Ballevre $\mathrm{O}$, and Beaufrere B. The rate of protein digestion affects protein gain differently during aging in humans. J Physiol 549: 635-644, 2003.

26. Dardevet D, Sornet C, Balage M, and Grizard J. Stimulation of in vitro rat muscle protein synthesis by leucine decreases with age. J Nutr 130: 2630-2635, 2000.

27. Dardevet D, Sornet C, Bayle G, Prugnaud J, Pouyet C, and Grizard J. Postprandial stimulation of muscle protein synthesis in old rats can be restored by a leucinesupplemented meal. J Nutr 132: 95-100, 2002.

28. Dean PM and Matthews EK. Glucose-induced electrical activity in pancreatic islet cells. J Physiol 210: 255-264, 1970.

29. Dela F, Larsen JJ, Mikines KJ, Ploug T, Petersen LN, and Galbo H. Insulin-stimulated muscle glucose clearance in patients with NIDDM. Effects of one-legged physical training. Diabetes 44: 1010-1020, 1995.

30. Dela F, Mikines KJ, von Linstow M, Secher NH, and Galbo H. Effect of training on insulin-mediated glucose uptake in human muscle. Am J Physiol 263: E1134-1143, 1992.

31. Dela F, Ploug T, Handberg A, Petersen LN, Larsen JJ, Mikines KJ, and Galbo H. Physical training increases muscle GLUT4 protein and mRNA in patients with NIDDM. Diabetes 43: 862-865, 1994.

32. Esmarck B, Andersen JL, Olsen S, Richter EA, Mizuno M, and Kjaer M. Timing of post-exercise protein intake is important for muscle hypertrophy with resistance training in elderly humans. J Physiol 535: 301-311, 2001.

33. Evans WJ. Effects of exercise on body composition and functional capacity of the elderly. J Gerontol A Biol Sci Med Sci 50 Spec No: 147-150, 1995.

34. Farrell PA, Fedele MJ, Hernandez J, Fluckey JD, Miller JL, 3rd, Lang CH, Vary TC, Kimball SR, and Jefferson LS. Hypertrophy of skeletal muscle in diabetic rats in response to chronic resistance exercise. J Appl Physiol 87: 1075-1082, 1999. 
35. Fenicchia LM, Kanaley JA, Azevedo JL, Jr., Miller CS, Weinstock RS, Carhart RL, and Ploutz-Snyder LL. Influence of resistance exercise training on glucose control in women with type 2 diabetes. Metabolism 53: 284-289, 2004.

36. Fiatarone MA, O'Neill EF, Ryan ND, Clements KM, Solares GR, Nelson ME, Roberts SB, Kehayias JJ, Lipsitz LA, and Evans WJ. Exercise training and nutritional supplementation for physical frailty in very elderly people. N Engl J Med 330: 1769 $1775,1994$.

37. Floyd JC, Jr., Fajans SS, Conn JW, Knopf RF, and Rull J. Stimulation of insulin secretion by amino acids. J Clin Invest 45: 1487-1502, 1966.

38. Floyd JC, Jr., Fajans SS, Conn JW, Thiffault C, Knopf RF, and Guntsche E. Secretion of insulin induced by amino acids and glucose in diabetes mellitus. J Clin Endocrinol Metab 28: 266-276, 1968.

39. Floyd JC, Jr., Fajans SS, Knopf RF, and Conn JW. Evidence that insulin release is the mechanism for experimentally induced leucine hypoglycemia in man. J Clin Endocrinol Metab 28: 266-276, 1963.

40. Floyd JC, Jr., Fajans SS, Pek S, Thiffault CA, Knopf RF, and Conn JW. Synergistic effect of certain amino acid pairs upon insulin secretion in man. Diabetes 19: 102-108, 1970.

41. Floyd JC, Jr., Fajans SS, Pek S, Thiffault CA, Knopf RF, and Conn JW. Synergistic effect of essential amino acids and glucose upon insulin secretion in man. Diabetes 19: 109-115, 1970.

42. Fryburg DA, Jahn LA, Hill SA, Oliveras DM, and Barrett EJ. Insulin and insulin-like growth factor-I enhance human skeletal muscle protein anabolism during hyperaminoacidemia by different mechanisms. J Clin Invest 96: 1722-1729., 1995.

43. Garlick PJ. The role of leucine in the regulation of protein metabolism. J Nutr 135: 1553S-1556S, 2005.

44. Gautsch TA, Anthony JC, Kimball SR, Paul GL, Layman DK, and Jefferson LS. Availability of eIF4E regulates skeletal muscle protein synthesis during recovery from exercise. Am J Physiol 274: C406-414, 1998.

45. Gelfand RA and Barrett EJ. Effect of physiologic hyperinsulinemia on skeletal muscle protein synthesis and breakdown in man. J Clin Invest 80: 1-6, 1987.

46. Gingras AC, Raught B, and Sonenberg N. eIF4 initiation factors: effectors of mRNA recruitment to ribosomes and regulators of translation. Annu Rev Biochem 68: 913 963, 1999.

47. Goldspink G. Changes in muscle mass and phenotype and the expression of autocrine and systemic growth factors by muscle in response to stretch and overload. J Anat 194 ( Pt 3): 323-334, 1999.

48. Guillet C, Prod'homme M, Balage M, Gachon P, Giraudet C, Morin L, Grizard J, and Boirie Y. Impaired anabolic response of muscle protein synthesis is associated with S6K1 dysregulation in elderly humans. Faseb J 18: 1586-1587, 2004.

49. Hameed M, Orrell RW, Cobbold M, Goldspink G, and Harridge SD. Expression of IGF-I splice variants in young and old human skeletal muscle after high resistance exercise. J Physiol 547: 247-254, 2003.

50. Hasten DL, Pak-Loduca J, Obert KA, and Yarasheski KE. Resistance exercise acutely increases MHC and mixed muscle protein synthesis rates in 78-84 and 23-32 yr olds. Am J Physiol Endocrinol Metab 278: E620-626, 2000.

51. Hawley JA. Adaptations of skeletal muscle to prolonged, intense endurance training. Clin Exp Pharmacol Physiol 29: 218-222, 2002.

52. Henriksen EJ. Invited Review: Effects of acute exercise and exercise training on insulin resistance. J Appl Physiol 93: 788-796, 2002. 
53. Hillier TA, Fryburg DA, Jahn LA, and Barrett EJ. Extreme hyperinsulinemia unmasks insulin's effect to stimulate protein synthesis in the human forearm. Am J Physiol 274: E1067-1074, 1998.

54. Hornsby PJ. Genes, hormones, and aging. Mol Cell Endocrinol 80: C175-180, 1991.

55. Hughes VA, Fiatarone MA, Fielding RA, Kahn BB, Ferrara CM, Shepherd P, Fisher EC, Wolfe RR, Elahi D, and Evans WJ. Exercise increases muscle GLUT-4 levels and insulin action in subjects with impaired glucose tolerance. Am J Physiol 264: E855-862, 1993.

56. Ji G, Barsotti RJ, Feldman ME, and Kotlikoff MI. Stretch-induced calcium release in smooth muscle. J Gen Physiol 119: 533-544, 2002.

57. Karlsson HK, Nilsson PA, Nilsson J, Chibalin AV, Zierath JR, and Blomstrand E. Branched-Chain Amino Acids Increase p70S6 Kinase Phosphorylation in Human Skeletal Muscle after Resistance Exercise. Am J Physiol Endocrinol Metab 287: E1-7, 2004.

58. Kimball SR. Regulation of global and specific mRNA translation by amino acids. J Nutr 132: 883-886, 2002.

59. Kimball SR, Farrell PA, and Jefferson LS. Invited Review: Role of insulin in translational control of protein synthesis in skeletal muscle by amino acids or exercise. J Appl Physiol 93: 1168-1180, 2002.

60. Kimball SR and Jefferson LS. Mechanisms of translational control in liver and skeletal muscle. Biochimie 76: 729-736, 1994.

61. Kimball SR and Jefferson LS. Regulation of global and specific mRNA translation by oral administration of branched-chain amino acids. Biochem Biophys Res Commun 313: 423-427, 2004.

62. Koopman R, Wagenmakers AJ, Manders RJ, Zorenc AH, Senden JM, Gorselink M, Keizer HA, and van Loon LJ. Combined ingestion of protein and free leucine with carbohydrate increases post-exercise muscle protein synthesis in vivo in male subjects. Am J Physiol Endocrinol Metab 288: E645-653, 2005.

63. Kraemer WJ and Fry AC. Strength Testing; Development and Evaluation of Methodology. In: Physiological Assesment of Human Fitness, edited by Maud PJ and Foster C. Leeds: Human Kinetics, 1995, p. 115-133.

64. Laurent GJ, Sparrow MP, and Millward DJ. Turnover of muscle protein in the fowl. Changes in rates of protein synthesis and breakdown during hypertrophy of the anterior and posterior latissimus dorsi muscles. Biochem J 176: 407-417, 1978.

65. Li JB and Jefferson LS. Influence of amino acid availability on protein turnover in perfused skeletal muscle. Biochim Biophys Acta 544: 351-359, 1978.

66. Liu Y, Lormes W, Reissnecker S, and Steinacker JM. Effects of high intensity resistance and low intensity endurance training on myosin heavy chain isoform expression in highly trained rowers. Int J Sports Med 24: 264-270, 2003.

67. Liu Z, Jahn LA, Long W, Fryburg DA, Wei L, and Barrett EJ. Branched chain amino acids activate messenger ribonucleic acid translation regulatory proteins in human skeletal muscle, and glucocorticoids blunt this action. J Clin Endocrinol Metab 86: 2136-2143, 2001.

68. MacDougall JD, Gibala MJ, Tarnopolsky MA, MacDonald JR, Interisano SA, and Yarasheski KE. The time course for elevated muscle protein synthesis following heavy resistance exercise. Can J Appl Physiol 20: 480-486, 1995.

69. MacDougall JD, Tarnopolsky MA, Chesley A, and Atkinson SA. Changes in muscle protein synthesis following heavy resistance exercise in humans: a pilot study. Acta Physiol Scand 146: 403-404, 1992. 
70. MacKenna DA, Dolfi F, Vuori K, and Ruoslahti E. Extracellular signal-regulated kinase and c-Jun NH2-terminal kinase activation by mechanical stretch is integrindependent and matrix-specific in rat cardiac fibroblasts. J Clin Invest 101: 301-310, 1998.

71. Matthews DE. Observations of branched-chain amino acid administration in humans. J Nutr 135: 1580S-1584S, 2005.

72. Miller SL, Tipton KD, Chinkes DL, Wolf SE, and Wolfe RR. Independent and Combined Effects of Amino Acids and Glucose after Resistance Exercise. Med Sci Sports Exerc 35: 449-455, 2003.

73. Miller WJ, Sherman WM, and Ivy JL. Effect of strength training on glucose tolerance and post-glucose insulin response. Med Sci Sports Exerc 16: 539-543, 1984.

74. Morgan HE, Earl DC, Broadus A, Wolpert EB, Giger KE, and Jefferson LS. Regulation of protein synthesis in heart muscle. I. Effect of amino acid levels on protein synthesis. J Biol Chem 246: 2152-2162, 1971.

75. Nader GA and Esser KA. Intracellular signaling specificity in skeletal muscle in response to different modes of exercise. J Appl Physiol 90: 1936-1942, 2001.

76. Nair KS. Aging muscle. Am J Clin Nutr 81: 953-963, 2005.

77. Nair KS, Halliday D, and Griggs RC. Leucine incorporation into mixed skeletal muscle protein in humans. Am J Physiol 254: E208-213, 1988.

78. Nair KS, Schwartz RG, and Welle S. Leucine as a regulator of whole-body and skeletal muscle protein metabolism in humans. Am J Physiol 263: E928-934, 1992.

79. Newsholme P, Brennan L, Rubi B, and Maechler P. New insights into amino acid metabolism, beta-cell function and diabetes. Clin Sci (Lond) 108: 185-194, 2005.

80. Paddon-Jones D, Sheffield-Moore M, Zhang XJ, Volpi E, Wolf SE, Aarsland A, Ferrando AA, and Wolfe RR. Amino acid ingestion improves muscle protein synthesis in the young and elderly. Am J Physiol Endocrinol Metab 286: E321-328, 2004.

81. Pain VM. Initiation of protein synthesis in eukaryotic cells. Eur J Biochem 236: 747771, 1996.

82. Perseghin G, Price TB, Petersen KF, Roden M, Cline GW, Gerow K, Rothman DL, and Shulman GI. Increased glucose transport-phosphorylation and muscle glycogen synthesis after exercise training in insulin-resistant subjects. N Engl J Med 335: 13571362, 1996.

83. Phillips SM, Parise G, Roy BD, Tipton KD, Wolfe RR, and Tamopolsky MA. Resistance-training-induced adaptations in skeletal muscle protein turnover in the fed state. Can J Physiol Pharmacol 80: 1045-1053, 2002.

84. Phillips SM, Tipton KD, Aarsland A, Wolf SE, and Wolfe RR. Mixed muscle protein synthesis and breakdown after resistance exercise in humans. Am J Physiol 273: E99107, 1997.

85. Phillips SM, Tipton KD, Ferrando AA, and Wolfe RR. Resistance training reduces the acute exercise-induced increase in muscle protein turnover. Am J Physiol 276: E118124, 1999.

86. Proud CG. mTOR-mediated regulation of translation factors by amino acids. Biochem Biophys Res Commun 313: 429-436, 2004.

87. Rasmussen BB, Tipton KD, Miller SL, Wolf SE, and Wolfe RR. An oral essential amino acid-carbohydrate supplement enhances muscle protein anabolism after resistance exercise. J Appl Physiol 88: 386-392, 2000.

88. Rattan SI. Synthesis, modifications, and turnover of proteins during aging. Exp Gerontol 31: 33-47, 1996.

89. Rennie MJ and Tipton KD. Protein and amino acid metabolism during and after exercise and the effects of nutrition. Annu Rev Nutr 20: 457-483, 2000. 
90. Reynolds TI, Bodine SC, and Lawrence JC, Jr. Control of Ser2448 Phosphorylation in the Mammalian Target of Rapamycin by Insulin and Skeletal Muscle Load. J Biol Chem 277: 17657-17662, 2002.

91. RIVM. Demografie: Vergrijzing per COROP-regio 1999-2025 - nationale Atlas Volksgezondheid. http://wwwrivmnl/vtv/object_map/o303n21018html.

92. Rogers MA, Yamamoto C, King DS, Hagberg JM, Ehsani AA, and Holloszy JO. Improvement in glucose tolerance after $1 \mathrm{wk}$ of exercise in patients with mild NIDDM. Diabetes Care 11: 613-618, 1988.

93. Roman WJ, Fleckenstein J, Stray-Gundersen J, Alway SE, Peshock R, and Gonyea WJ. Adaptations in the elbow flexors of elderly males after heavy-resistance training. J Appl Physiol 74: 750-754, 1993.

94. Rooyackers OE, Adey DB, Ades PA, and Nair KS. Effect of age on in vivo rates of mitochondrial protein synthesis in human skeletal muscle. Proc Natl Acad Sci U S A 93: 15364-15369, 1996.

95. Roy BD, Tarnopolsky MA, MacDougall JD, Fowles J, and Yarasheski KE. Effect of glucose supplement timing on protein metabolism after resistance training. J Appl Physiol 82: 1882-1888, 1997.

96. Sener A and Malaisse WJ. L-leucine and a nonmetabolized analogue activate pancreatic islet glutamate dehydrogenase. Nature 288: 187-189, 1980.

97. Short KR, Vittone JL, Bigelow ML, Proctor DN, and Nair KS. Age and aerobic exercise training effects on whole-body and muscle protein metabolism. Am J Physiol Endocrinol Metab 286: E92-101, 2004.

98. Short KR, Vittone JL, Bigelow ML, Proctor DN, Rizza RA, Coenen-Schimke JM, and Nair KS. Impact of aerobic exercise training on age-related changes in insulin sensitivity and muscle oxidative capacity. Diabetes 52: 1888-1896, 2003.

99. Tipton KD, Ferrando AA, Phillips SM, Doyle D, Jr., and Wolfe RR. Post-exercise net protein synthesis in human muscle from orally administered amino acids. Am J Physiol 276: E628-634, 1999.

100.van Loon LJ. Amino acids as pharmaco-nutrients for the treatment of type 2 diabetes. Curr Med Chem in press, 2006.

101.van Loon LJ, Kruijshoop M, Menheere PP, Wagenmakers AJ, Saris WH, and Keizer HA. Amino acid ingestion strongly enhances insulin secretion in patients with longterm type 2 diabetes. Diabetes Care 26: 625-630, 2003.

102.van Loon LJ, Kruijshoop M, Verhagen H, Saris WH, and Wagenmakers AJ. Ingestion of protein hydrolysate and amino acid-carbohydrate mixtures increases post-exercise plasma insulin responses in men. J Nutr 130: 2508-2513, 2000.

103. van Loon LJ, Saris WH, Kruijshoop M, and Wagenmakers AJ. Maximizing postexercise muscle glycogen synthesis: carbohydrate supplementation and the application of amino acid or protein hydrolysate mixtures. Am J Clin Nutr 72: 106-111, 2000.

104. van Loon LJ, Saris WH, Verhagen H, and Wagenmakers AJ. Plasma insulin responses after ingestion of different amino acid or protein mixtures with carbohydrate. Am J Clin Nutr 72: 96-105, 2000.

105. Volpi E, Ferrando AA, Yeckel CW, Tipton KD, and Wolfe RR. Exogenous amino acids stimulate net muscle protein synthesis in the elderly. J Clin Invest 101: 20002007, 1998.

106.Volpi E, Mittendorfer B, Rasmussen BB, and Wolfe RR. The response of muscle protein anabolism to combined hyperaminoacidemia and glucose-induced hyperinsulinemia is impaired in the elderly. J Clin Endocrinol Metab 85: 4481-4490, 2000. 
107. Volpi E, Mittendorfer B, Wolf SE, and Wolfe RR. Oral amino acids stimulate muscle protein anabolism in the elderly despite higher first-pass splanchnic extraction. Am J Physiol 277: E513-520, 1999.

108. Volpi E, Sheffield-Moore M, Rasmussen BB, and Wolfe RR. Basal muscle amino acid kinetics and protein synthesis in healthy young and older men. Jama 286: 1206-1212, 2001.

109. Wagenmakers AJ. Tracers to investigate protein and amino acid metabolism in human subjects. Proc Nutr Soc 58: 987-1000, 1999.

110. Welle S, Bhatt K, and Thornton C. Polyadenylated RNA, actin mRNA, and myosin heavy chain mRNA in young and old human skeletal muscle. Am J Physiol 270: E224229, 1996.

111. Welle S, Bhatt K, and Thornton CA. Stimulation of myofibrillar synthesis by exercise is mediated by more efficient translation of mRNA. J Appl Physiol 86: 1220-1225, 1999.

112. Welle S, Thornton C, Jozefowicz R, and Statt M. Myofibrillar protein synthesis in young and old men. Am J Physiol 264: E693-698, 1993.

113. Welle S, Thornton C, and Statt M. Myofibrillar protein synthesis in young and old human subjects after three months of resistance training. Am J Physiol 268: E422-427, 1995.

114. Welle S and Thornton CA. High-protein meals do not enhance myofibrillar synthesis after resistance exercise in 62- to 75-yr-old men and women. Am J Physiol 274: E677683, 1998.

115. Willoughby DS and Nelson MJ. Myosin heavy-chain mRNA expression after a single session of heavy-resistance exercise. Med Sci Sports Exerc 34: 1262-1269, 2002.

116. Wolfe RR. Radioactive and stable isotope tracers in biomedicine: principles and practice of kinetic analysis. New York: Wiley-Liss, 1992.

117.Xu G, Kwon G, Cruz WS, Marshall CA, and McDaniel ML. Metabolic regulation by leucine of translation initiation through the mTOR-signaling pathway by pancreatic beta-cells. Diabetes 50: 353-360, 2001.

118. Yarasheski KE, Welle S, and Sreekumaran Nair K. Muscle protein synthesis in younger and older men. Jama 287: 317-318, 2002.

119. Yarasheski KE, Zachwieja JJ, and Bier DM. Acute effects of resistance exercise on muscle protein synthesis rate in young and elderly men and women. Am J Physiol 265: E210-214, 1993. 



\section{2}

\section{A single session of resistance exercise enhances insulin sensitivity for at least 24hours in healthy men}

René Koopman, Ralph J.F. Manders, Antoine H.G. Zorenc, Gabby B.J. Hul, Harm Kuipers, Hans A. Keizer and Luc J.C. van Loon

Eur J Appl Physiol (2005). 94:180-187 


\begin{abstract}
The aim of the present study was to determine whether a single session of resistance exercise improves whole-body insulin sensitivity in healthy men for up to $24 \mathrm{~h}$. Twelve male subjects $(23 \pm 1 \mathrm{y})$ were studied over a period of 4 days during which they consumed a standardized diet, providing $0.16 \pm 0.01 \mathrm{MJ} \cdot \mathrm{kg}^{-1} \cdot \mathrm{day}^{-1}$ containing $15 \pm 0.1 \mathrm{Energy} \%$ (En\%) protein, $29 \pm 0.1 \mathrm{En} \%$ fat and $55 \pm 0.3 \mathrm{En} \%$ carbohydrate. Insulin sensitivity was determined $24 \mathrm{~h}$ before and $24 \mathrm{~h}$ after a single resistance exercise session (8 sets of 10 repetitions at $75 \%$ of 1 -repetition maximum for 2 leg exercise tasks) using an intravenous insulin tolerance test. Insulin sensitivity index was calculated by the decline in arterialized blood glucose concentration following intravenous administration of a single bolus of human insulin (0.075 IU $\cdot \mathrm{kg}^{-1}$ fat free mass). Basal glucose and insulin concentrations were not changed $24 \mathrm{~h}$ after resistance exercise. However, a substantial 13 $\pm 5 \%$ improvement in whole-body insulin sensitivity was observed $24 \mathrm{~h}$ after resistance exercise $(\mathrm{P}<0.05)$. This study shows that even a single session of resistance exercise improves whole-body insulin sensitivity for up to $24 \mathrm{~h}$ in healthy men, which is consistent with earlier observations following endurance exercise tasks.
\end{abstract}




\section{Introduction}

Skeletal muscle tissue is responsible for most of the insulin stimulated glucose uptake in humans. The capacity for insulin-mediated glucose uptake is directly related to total muscle mass and inversely associated with fat mass (58). In type 2 diabetes patients, insulin-stimulated glucose uptake is substantially impaired in liver and skeletal muscle tissue, leading to the development of a hyperinsulinemic and/or hyperglycemic state (9). The development of insulin resistance and/or type 2 diabetes is strongly associated with the presence of obesity and physical inactivity $(18,31,44)$. Weight loss $(23,30,45)$, increased physical activity (27), as well as pharmacological interventions $(33,34,49)$ have been shown to form effective strategies to improve insulin sensitivity.

Studies investigating the role of physical activity as a means to improve insulin sensitivity generally apply endurance exercise as a model. Endurance exercise allows the use of a relatively large amount of muscle for a prolonged period of time, and, as such, forms a safe and effective means to elevate energy expenditure and promote weight loss (16). Prolonged endurance exercise training has been shown to improve insulin sensitivity in young (11), elderly (36) and/or insulinresistant subjects $(4,10,12,32,46,48)$. However, even a single bout of moderateto-high-intensity endurance exercise has been shown to acutely improve insulin sensitivity and/or glucose tolerance $(14,15,26,42,46)$. This effect has been reported to persist for a period ranging from $2 \mathrm{~h}(42), 4-6 \mathrm{~h}(56), 12-16 \mathrm{~h}(14,15,26)$ to up to $48 \mathrm{~h}$ post-exercise $(42,46)$.

In contrast to endurance exercise, limited information is available on the potential of resistance exercise to affect insulin sensitivity and/or glucose tolerance $(51,52)$. Some studies have demonstrated that 6-12 wk of progressive resistance training improves glucose tolerance $(8,19,43)$. These changes are generally attributed to the concomitant gain in skeletal muscle mass. Unfortunately, the few studies that investigated the more acute effects of resistance exercise have provided contradictory findings. Whereas some have reported an improved glucoregulatory response $12-24 \mathrm{~h}$ after a single bout of resistance exercise $(19,20)$, others have failed to observe any change in insulin sensitivity (6). The apparent discrepancy in the literature is likely due to the methods used to determine insulin sensitivity and/or glucose tolerance. Most studies have applied an oral glucose tolerance test (OGTT) as a surrogate measure of insulin sensitivity. However, the OGTT has been reported to have a questionable reproducibility (37). In contrast to the OGTT, the insulin tolerance test (ITT) directly measures insulin sensitivity (28) and has been validated using the euglycaemic hyperinsulinemic clamp (1). Therefore, in the present study we applied the ITT' to investigate the short-term effects of a single resistance exercise session on whole-body insulin sensitivity. 


\section{Methods}

\section{Subjects}

Twelve healthy male volunteers with no history of participating in any regular exercise program were recruited for the present study. Subject characteristics are shown in table 2.1. All subjects were informed on the nature and possible risks of the experimental procedures before their written informed consent was obtained. The latter after approval by the Medical Ethical Committee of the Academic Hospital Maastricht, The Netherlands.

Table 2.1 Subjects' characteristics

\begin{tabular}{lc}
\hline & Mean \pm SEM \\
\hline Age (yrs) & $23.0 \pm 1.0$ \\
Weight $(\mathrm{kg})$ & $74.3 \pm 2.8$ \\
Height $(\mathrm{m})$ & $1.79 \pm 0.02$ \\
BMI $\left(\mathrm{kg} \cdot \mathrm{m}^{-2}\right)$ & $23.1 \pm 0.7$ \\
$\%$ bodyfat $(\%)$ & $17.1 \pm 2.2$ \\
Fat free mass $(\mathrm{kg})$ & $61.2 \pm 1.8$ \\
Fat mass $(\mathrm{kg})$ & $13.1 \pm 1.9$ \\
HbA $1 \mathrm{C}(\%)$ & $5.23 \pm 0.08$ \\
1RM leg press $(\mathrm{kg})$ & $198 \pm 8$ \\
1RM leg press $(\mathrm{kg} \cdot \mathrm{BW}-1)$ & $2.67 \pm 0.08$ \\
1RM leg extension $(\mathrm{kg})$ & $108 \pm 4$ \\
1RM leg extension $\left(\mathrm{kg} \cdot \mathrm{BW}^{-1}\right)$ & $1.46 \pm 0.05$ \\
\hline
\end{tabular}

Values are expressed as means \pm SEM.

\section{Pretesting}

All subjects reported to the laboratory in the morning after an overnight fast for measurement of body composition, assessed using the hydrostatic weighing method. Residual lung volume was measured by the helium-dilution technique using a spirometer (Volugraph 2000, Mijnhart, Bunnik, The Netherlands). Body weight was measured with a digital balance with an accuracy of $0.001 \mathrm{~kg}$ (E1200, August Sauter GmbH, Albstadt, Germany). Body fat percentage was calculated using Siri's equation (50). Fat Free mass (FFM) was calculated by subtracting fat mass from total body mass.

Thereafter, subjects participated in an exercise trial to become familiarized with the exercise protocol and the equipment. Proper lifting technique was demonstrated and practiced for each of the 2 lower-limb exercises (leg press and leg extension) and for the 3 upper-body exercises (chest press, shoulder press and lat-pulldown). Thereafter maximum strength was estimated using the multiple repetitions testing procedure (41). In another session, at least $1 \mathrm{wk}$ before the first experimental trial, subjects' 1 repetition maximum (1RM) was determined (38). After warming up, the load was set at $90-95 \%$ of the estimated 1RM, and increased after each successful lift until failure. A 5 min resting period between subsequent attempts was allowed. 
A repetition was valid if the subject was able to complete the entire lift in a controlled manner without assistance.

\section{Standardization diet and activity prior to testing}

All subjects received a standardization diet for 4 days, i.e. the day prior to the Insulin Tolerance Test (IT'T) (on day 1), the IT'T (on day 2), the resistance exercise session (on day 3), and the second ITT (on day 4), which were performed at exactly $8.30 \mathrm{am}$ in the morning after an overnight fast. Subjects were provided with a pre-weighed amount of food products, beverages, and instant meals and were allowed to drink water ad libitum. All main meals (breakfast, lunch, and dinner) and between-meal snacks were instructed to be taken at predetermined time intervals during each day. Subjects were asked to record their food intake during the entire testing period. Energy intake averaged $0.16 \pm 0.01 \mathrm{MJ} \cdot \mathrm{kg}$ bodyweight ${ }^{-1} \cdot \mathrm{day}^{-1}$ containing $15 \pm 0.1$ Energy $\%(\mathrm{En} \%)$ of protein, $29 \pm 0.1 \mathrm{En} \%$ of fat and $55 \pm 0.3$ En\% of carbohydrate. Energy intake did not differ significantly between days, even though subjects were free to increase or decrease portion size of all meals and snacks. All volunteers were instructed to refrain from any sort of heavy physical exercise during the entire period except for the resistance exercise session.

No heavy physical activity (except for the single bout of resistance exercise)

Standardization diet:

$0.16 \mathrm{MJ}^{\mathrm{kg}}{ }^{-1}: 15 \mathrm{En} \%$ protein, $29 \mathrm{En} \%$ fat and $55 \mathrm{En} \%$ carbohydrate

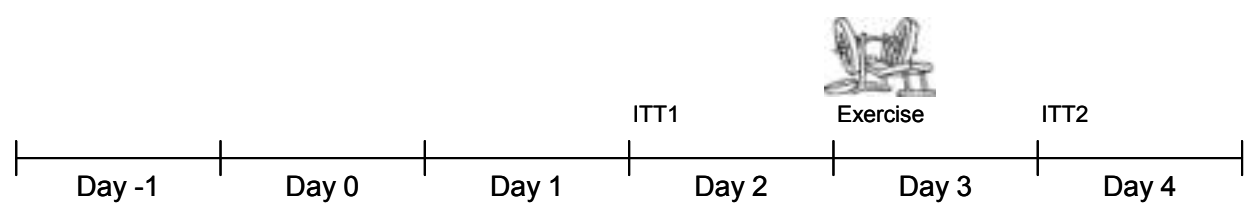

Figure 2.1 Overview of the study design. All subjects received a standardization diet during the entire study period; prior to the day preceding the first Insulin Tolerance Test (ITT) (day 1), the ITT (day 2), the resistance exercise session (day 3), and the second ITT (day 4), which were performed at exactly 8.30 am in the morning after an overnight fast. All volunteers were instructed to refrain from any sort of heavy physical exercise during the entire period (6 days) except for the resistance exercise session.

\section{Experimental trials}

An overview of the study protocol is provided in figure 2.1. One week after the subjects completed their 1RM-test, insulin sensitivity was measured using a short Insulin Tolerance Test (IT'T). 24h after the ITT, subjects exercised for $\sim 1 \mathrm{~h}$ using 
the resistance exercise machines. The resistance exercise was followed $24 \mathrm{~h}$ later with a second IT'T.

\section{$I T T$}

The day before and after the resistance exercise session, subjects arrived at the laboratory by car or public transportation (to avoid disturbances in insulin sensitivity due to physical activity: i.e. cycling, stair walking) at 8.00 am after an overnight fast. A Teflon catheter was inserted into an antecubital vein for insulin infusion and a second Teflon catheter was inserted retrogradely in a dorsal vein of the contralateral hand, which was placed in a hot-box $\left(60^{\circ} \mathrm{C}\right)$, for arterialised blood sampling. After $30 \mathrm{~min}$ of incline bed rest, a basal blood sample was collected $(\mathrm{t}=-5 \mathrm{~min})$. Another blood sample $(\mathrm{t}=0 \mathrm{~min})$ was obtained before administration of a single intravenous dose of human insulin (Actrapid ${ }^{\circledR}$, Novo Nordisk A/S, Bagsværd, Denmark) of $0.075 \mathrm{IU} \cdot \mathrm{kg}^{-1}$ fat free mass. Thereafter, blood samples were collected every 2 min until $\mathrm{t}=16 \mathrm{~min}$. Thereafter, the test was terminated and subjects consumed a standardised breakfast.

Blood samples were taken for blood glucose measurement (see analyses section). In addition, blood glucose concentrations were directly monitored using a blood glucose monitor (Precision Xtra, MediSense, Amersfoort, The Netherlands) at $\mathrm{t}=0$, $6,12,16 \mathrm{~min}$. If blood glucose $<2.5 \mathrm{mmol} \cdot \mathrm{L}^{-1}$ at $\mathrm{t}=16 \mathrm{~min}$ a $10 \mathrm{ml}$ bolus of $20 \%$ dextrose (Baxter B.V., Utrecht, The Netherlands) was injected, to prevent severe hypoglycaemia. Blood glucose was checked again at 22 and $30 \mathrm{~min}$ after insulin injection. No subjects reported symptoms of hypoglycaemia during the ITT, and/or during the 20-30 min after insulin administration.

\section{Resistance exercise}

The day after the first IT'T subjects arrived at the laboratory by car or public transportation at $8.00 \mathrm{am}$, in an overnight fasted state. Subjects performed a general warm-up of 5 min using a Stairmaster, followed by 3 sets of 10 repetitions on 3 resistance exercise machines targeting the upper-body (chest-press, shoulderpress and lat-pulldown, Jimsa Benelux BV, Rotterdam, The Netherlands). The latter were included to provide a whole-body warm-up and to reduce the risk of injury. Thereafter, the resistance exercise session targeted the legs, with 8 sets of 10 repetitions on the horizontal leg press machine (Technogym BV, Rotterdam, The Netherlands) and 8 sets of 10 repetitions on the leg extension machine (Technogym). Both exercises were performed at $75 \%$ of the subjects' individual $1 \mathrm{RM}$ with 2 min rest intervals between sets and in total required $\sim 40 \mathrm{~min}$ to complete. All subjects were verbally encouraged during the test to complete the entire protocol. At the end of the exercise session, subjects consumed a standardized breakfast. Energy expenditure during the exercise session was not measured. Based on indirect calorimetry measurements during similar resistance exercise protocols, others have shown energy expenditure rates ranging between 14 and $27 \mathrm{~kJ} \cdot \min ^{-1}(2,5,47)$. 


\section{Analysis}

Blood samples $(4 \mathrm{ml})$ were collected in tubes containing a glycolytic inhibitor (sodium fluoride) and anticoagulant (potassium oxalate) and placed on ice. After centrifugation at $1000 \cdot \mathrm{g}$ and $4^{\circ} \mathrm{C}$ for $5 \mathrm{~min}$ aliquots of plasma were frozen immediately in liquid nitrogen and stored at $-80^{\circ} \mathrm{C}$ until analyses. Plasma glucose (Uni Kit III, 07367204, Roche, Basel, Switzerland) concentrations were analyzed with the COBAS FARA semi-automatic analyzer (Roche). Plasma insulin was measured by radioimmunoassay (HI-11K, Linco Research Inc., St. Charles, MO, USA). To determine basal fasting blood $\mathrm{HbA}_{1 \mathrm{C}}$ content a $3 \mathrm{ml}$ blood sample was collected in EDTA containing tubes and analyzed by high-performance liquid chromatography (Bio-Rad Diamat, Munich, Germany).

\section{Calculation of insulin sensitivity}

The decline in blood glucose between 4 and 16 min during the ITT was used to determine insulin sensitivity (ISindex) (4). Linear regression was used to calculate the slope of the decline in log transformed blood glucose concentration against time during the first $4-16 \mathrm{~min}(1,4,28)$. The slope was multiplied by -100 to derive the rate constant $\left(\mathrm{K}_{\mathrm{ITT}}\right)$ which is equivalent to the percentage decline in blood glucose per min (28).

Insulin sensitivity was also estimated by the homeostasis model assessment or HOMA-Insulin Resistance (IR) index which is calculated by dividing the product of fasting plasma glucose $\left(\mathrm{mmol} \cdot \mathrm{L}^{-1}\right)$ and insulin concentrations $\left(\mathrm{mU} \cdot \mathrm{L}^{-1}\right)$ by 22.5 (40).

\section{Statistics}

All data are expressed as means \pm SEM. IS index $\left(\mathrm{K}_{\text {ITT }}\right)$ calculated from data obtained during IT'T1 and ITT2 were compared using a two-tailed, paired t-test. In addition, simple regression analysis was performed to calculate correlations between basal insulin, glucose, $\mathrm{IS}_{\text {index }}$ and HOMA index. Statistical significance was set at $\mathrm{P}<0.05$.

\section{Results}

\section{Resistance exercise}

Mean 1 repetition maximum (1RM) measured during the pre-testing was $198 \pm 8 \mathrm{~kg}$ on the horizontal leg press and $108 \pm 4 \mathrm{~kg}$ on the leg extension. Therefore, average weights used during the resistance exercise were $148 \pm 6$ and $81 \pm 3 \mathrm{~kg}$ for the leg press and leg extension, respectively. All subjects completed 8 sets with 10 repetitions on the leg press. However, during the $6^{\text {th }}$ set, 2 subjects could not finish all 10 repetitions, after which weight was reduced to $65 \%$ of the individual 1RM. 
Ten subjects completed 8 sets of 10 repetitions on the leg extension. Two subjects were not able to finish the last 2 sets due to dizziness.

\section{Plasma analyses}

Table 2.2 Blood parameters

\begin{tabular}{lcl}
\hline & ITT 1 & \multicolumn{1}{c}{ ITT 2 } \\
\hline Basal glucose $\left(\mathrm{mmol} \cdot \mathrm{L}^{-1}\right)$ & $5.44 \pm 0.12$ & $5.45 \pm 0.10$ \\
Glucose at $\mathrm{t}=16\left(\mathrm{mmol} \cdot \mathrm{L}^{-1}\right)$ & $3.00 \pm 0.18$ & $2.73 \pm 0.19^{*}$ \\
KITT $\left(\% \cdot \mathrm{min}^{-1}\right)$ & $5.07 \pm 0.37$ & $5.77 \pm 0.53 *$ \\
Basal insulin & $5.35 \pm 0.43$ & $5.51 \pm 0.35$ \\
HOMA-(IR) index & $1.29 \pm 0.11$ & $1.33 \pm 0.08$ \\
\hline
\end{tabular}

Values are expressed as means \pm SEM. * Significantly different from ITT1, P $<0.05$.

All subjects showed normal fasting plasma glucose $\left(5.42 \pm 0.13 \mathrm{mmol} \cdot \mathrm{l}^{-1}\right)$ and insulin concentrations $\left(5.35 \pm 0.43 \mathrm{mU} \cdot \mathrm{L}^{-1}\right)$ before the start of the first ITT. Basal plasma glucose concentrations were similar before the IT'T1 and IT'T2 trial (5.42 \pm 0.13 vs. $5.45 \pm 0.10 \mathrm{mmol} \cdot \mathrm{L}^{-1}$, respectively). Basal plasma insulin concentrations did not differ between the ITT1 and ITT2 $\left(5.35 \pm 0.43\right.$ and $5.51 \pm 0.35 \mathrm{mU} \cdot \mathrm{L}^{-1}$, respectively). The HOMA-(IR) index before ITT1 and IT'T2 averaged $1.29 \pm 0.11$ and $1.33 \pm 0.08$, respectively (NS). An overview of the plasma data is presented in table 2.2 .

\section{Intravenous insulin tolerance test}

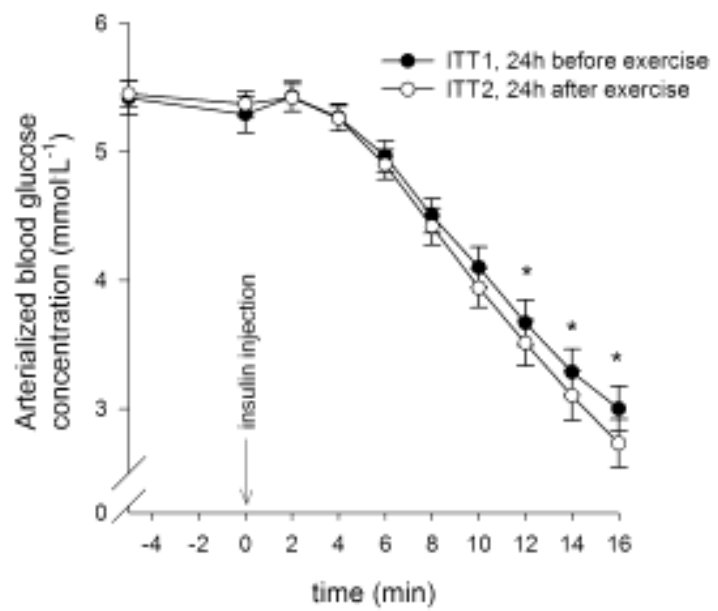

Figure 2.2 Plasma glucose concentrations following injection of a bolus of insulin $\left(0.075 \mathrm{IU} \cdot \mathrm{kg}^{-1}\right.$ fat free mass $)$ $24 \mathrm{~h}$ before and $24 \mathrm{~h}$ after a single bout of resistance exercise. Values are expressed as means \pm SEM. $*$ Significantly different from basal blood glucose concentrations during ITT1 and ITT2 $(\mathrm{P}<0.01)$ 
During the first ITT, the administration of insulin resulted in a decline in plasma glucose concentration from $5.27 \pm 0.11 \mathrm{mmol} \cdot \mathrm{L}^{-1}$ at $\mathrm{t}=4 \mathrm{~min}$ to $3.00 \pm 0.18 \mathrm{mmol} \cdot \mathrm{L}^{-1}$ at $\mathrm{t}=16 \mathrm{~min}$. During the ITT $24 \mathrm{~h}$ after resistance exercise (ITT2), plasma glucose concentrations were reduced from $5.26 \pm 0.10 \mathrm{mmol} \cdot \mathrm{L}^{-1}$ at $\mathrm{t}=4 \mathrm{~min}$ to $2.73 \pm 0.19$ $\mathrm{mmol} \cdot \mathrm{L}^{-1}$ at $\mathrm{t}=16 \mathrm{~min}$. Plasma glucose levels at $\mathrm{t}=16 \mathrm{~min}$ were significantly lower in ITT2 compared to ITT1 $(\mathrm{P}<0.05)$. The decline in blood glucose concentration is presented in figure 2.2.

Calculated rate constants for the glucose disappearance (KITT, \% $\mathrm{min}^{-1}$ ) between 4-16 min following insulin injection during a short insulin tolerance test (ITT) before, and $24 \mathrm{~h}$ after resistance exercise are shown in figure $2.3 \mathrm{~A}$. KITT values were significantly increased with $13.4 \pm 4.8 \% 24 \mathrm{~h}$ post-exercise compared to preexercise values ( $5.1 \pm 0.4$ vs. $\left.5.8 \pm 0.5 \% \cdot \mathrm{min}^{-1}, \mathrm{P}<0.05\right)$. The individual KITT values of blood glucose after insulin administration during the ITT before and 24h after resistance exercise are shown in figure 2.3B.
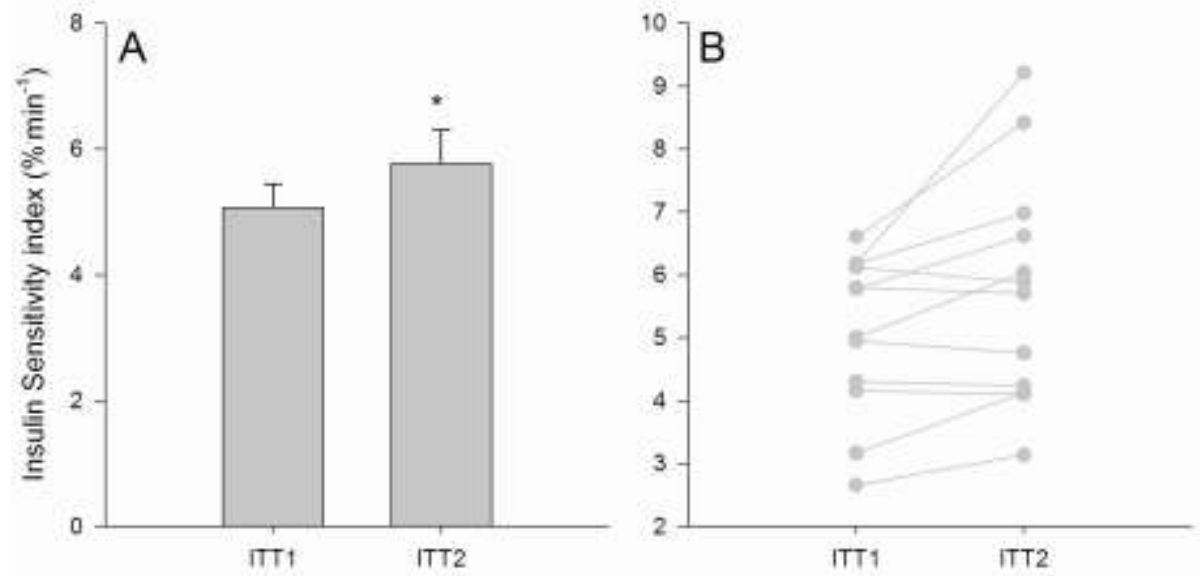

Figure 2.3 Insulin Sensitivity index presented as the mean rate constants for the disappearance (KITT) of blood glucose following insulin injection during a short insulin tolerance test (ITT) before, and 24h after resistance exercise (A). Values are expressed as means \pm SEM. ${ }^{*}$ significantly different from values observed during ITT1 $(\mathrm{P}<0.05)$. Individual results showing KITT values of blood glucose after insulin administration during the ITT before and $24 \mathrm{~h}$ after resistance exercise (B).

\section{Discussion}

It has been well established that a single bout of endurance exercise improves whole-body insulin sensitivity for up to $24 \mathrm{~h}$. In the present study, we extend on those findings by showing that a single session of resistance exercise can also effectively increase whole-body insulin sensitivity for up to $24 \mathrm{~h}$ in healthy males. Endurance exercise training has been reported to improve whole-body insulin sensitivity in young (11), elderly (36) and insulin-resistant subjects $(4,10,12,32,46$, 48). The latter is attributed to the concomitant induction of weight loss (16) and the upregulation of skeletal muscle GLUT-4 expression (7). Besides the more 
prolonged adaptive response to endurance training, it has been firmly established that even an acute bout of endurance exercise elevates whole-body insulin sensitivity for a prolonged period, ranging from 2 (42), 4-6 (56), 12-16 (14, 15, 26) to up to $48 \mathrm{~h}$ following cessation of exercise $(42,46)$. The latter is generally attributed to attenuated muscle GLUT-4 translocation (53) as well as increased GLUT-4 expression in muscle tissue (39). Factors thought to play a major regulatory role in this process include muscle lipid content (54) in relation with physical inactivity, AMPK activation $(21,25,55)$, muscle glycogen content and subsequent activation of glycogen synthase activity $(3,13,22,46,56,57)$, which enhance insulin signalling downstream of the receptor $(24,27)$.

In addition to prolonged endurance training, resistance exercise interventions have also been reported to improve glucose tolerance and/or whole-body insulin sensitivity $(8,17,19,29,35,43)$. The latter is generally attributed to a concomitant gain in skeletal muscle tissue, which improves whole-body glucose disposal capacity $(8,19,43)$. Besides this increase in lean muscle tissue, resistance exercise also improves functional capacity, thereby supporting a more active, healthy lifestyle. However, in the development of most exercise intervention programs, the focus generally lies on the implementation of endurance exercise because of its acute stimulating effect on whole-body insulin sensitivity. Consequently, endurance exercise sessions are generally implemented at the expense of resistance exercise when designing such intervention programs. In the present study, we speculated that a single resistance exercise session could also acutely improve whole-body insulin sensitivity. The latter would imply that there is no need to restrict the inclusion of resistance exercise when designing effective lifestyle intervention programs.

So far, the few studies that investigated the acute effects of resistance exercise on insulin sensitivity have provided contradictory findings $(6,19,20)$. In the present study, we show that a single resistance exercise session (mainly consisting of 16 sets of leg-exercise using $75 \%$ of the individual 1RM) improves whole-body insulin sensitivity by as much as $13.4 \pm 4.8 \%$ when measured $24 \mathrm{~h}$ after exercise. However, a large inter-subject variation was observed. Whereas 5 subjects did not show a measurable increase in plasma glucose clearance $24 \mathrm{~h}$ after resistance exercise, the 7 other subjects showed improvements in insulin sensitivity ranging between 13 and $49 \%$. The average increase in whole-body insulin sensitivity following resistance exercise seems to be of a similar magnitude as the $\sim 20 \%$ improvement reported following an acute $(\sim 60 \mathrm{~min})$ bout of endurance exercise $(42,46)$. Previous studies, investigating the acute effects of resistance exercise on insulin sensitivity, have applied either oral $(19,20)$ or intravenous (6) glucose tolerance tests (OGTT and IVGTT, respectively) to estimate insulin sensitivity. These studies, which use the glucose and/or insulin response following glucose administration as a representative of insulin action, have provided discrepant findings. Fluckey et al. (1994) reported no change in integrated glucose concentrations following glucose ingestion $18 \mathrm{~h}$ after resistance exercise, but observed a lower insulin response (20). Fenicchia et al. (2004) reported a lower glucose response 12-24h after resistance exercise in female type 2 diabetes patients, without observing any difference in 
insulin levels. In that study as well as in a study by Chapman et al. (2002), no changes in glucose or insulin responses were observed $15 \mathrm{~h}$ after a single bout of resistance exercise in the healthy, non-obese, normoglycaemic controls $(6,19)$. Clearly, in the literature the acute effects of resistance exercise on whole-body insulin sensitivity have always remained equivocal.

The discrepancy in these earlier findings could likely be attributed to the use of glucose tolerance tests, which do not measure insulin sensitivity directly. In accordance, the OGTT has been reported to have a questionable reproducibility as a measure of whole-body insulin sensitivity (37). Therefore, in the present study, we applied an intravenous insulin tolerance test (ITT) $24 \mathrm{~h}$ before and $24 \mathrm{~h}$ after performing a resistance exercise session. We observed a greater arterial blood glucose clearance rate following an intravenous dose of insulin $24 \mathrm{~h}$ after resistance exercise compared with pre-exercise values (figure 2.3). During the ITT, insulin sensitivity index was calculated by the observed decline in arterial blood glucose following insulin administration. In contrast to the OGTT, the ITT provides a reproducible method that more directly assesses insulin sensitivity (28), and has been validated using the euglycaemic hyperinsulinemic clamp (1). Other factors that might explain the discrepant findings in the literature include the intensity and/or duration of the resistance exercise session, the standardization of dietary intake and daily physical activity as well as the population studied. The resistance exercise protocol used both by Fluckey et al. (1994) and Chapman et al. (2002) may not have been of sufficient intensity to invoke a large significant improvement in whole-body insulin sensitivity as observed in the present study. Furthermore, many of the earlier studies did not standardize food intake and/or physical activity prior to the OGTTs $(19,20)$. In the present study, both food intake and physical activity were strictly standardized to reduce any confounding effects of diet on insulin sensitivity.

In the present study we show that resistance exercise acutely stimulates insulin sensitivity. Similar to the reported effects of a single bout of endurance exercise, this is likely attributed to attenuated muscle GLUT-4 translocation (53) and/or elevated GLUT-4 expression (39). Though information on the metabolic demand imposed upon by resistance exercise is scarce, we speculate that resistance exercise activates AMPK and substantially reduces muscle glycogen and/or IMTG content. More research is warranted to elucidate the exact mechanisms responsible for the observed increase in insulin sensitivity following exercise. In conclusion, an acute bout of intense resistance exercise substantially improves whole-body insulin sensitivity for up to $24 \mathrm{~h}$ after cessation of exercise. Therefore, the present data indicate that both endurance as well as resistance type exercise tasks stimulate insulin sensitivity. As such, there should be no restriction in combining the benefits of both types of exercise in future lifestyle intervention programs. 


\section{References}

1. Akinmokun A, Selby PL, Ramaiya K, and Alberti KG. The short insulin tolerance test for determination of insulin sensitivity: a comparison with the euglycaemic clamp. Diabet Med 9: 432-437, 1992.

2. Ballor DL, Katch VL, Becque MD, and Marks CR. Resistance weight training during caloric restriction enhances lean body weight maintenance. Am J Clin Nutr 47: 19-25, 1988.

3. Bogardus C, Thuillez P, Ravussin E, Vasquez B, Narimiga M, and Azhar S. Effect of muscle glycogen depletion on in vivo insulin action in man. J Clin Invest 72: 1605-1610, 1983.

4. Borghouts LB, Backx K, Mensink MF, and Keizer HA. Effect of training intensity on insulin sensitivity as evaluated by insulin tolerance test. Eur J Appl Physiol Occup Physiol 80: 461-466, 1999.

5. Burleson MA, Jr., O'Bryant HS, Stone MH, Collins MA, and Triplett-McBride T. Effect of weight training exercise and treadmill exercise on post-exercise oxygen consumption. Med Sci Sports Exerc 30: 518-522, 1998.

6. Chapman J, Garvin AW, Ward A, and Cartee GD. Unaltered insulin sensitivity after resistance exercise bout by postmenopausal women. Med Sci Sports Exerc 34: 936$941,2002$.

7. Cox JH, Cortright RN, Dohm GL, and Houmard JA. Effect of aging on response to exercise training in humans: skeletal muscle GLUT-4 and insulin sensitivity. J Appl Physiol 86: 2019-2025, 1999.

8. Craig BW, Everhart J, and Brown R. The influence of high-resistance training on glucose tolerance in young and elderly subjects. Mech Ageing Dev 49: 147-157, 1989.

9. DeFronzo RA, Ferrannini E, and Koivisto V. New concepts in the pathogenesis and treatment of noninsulin-dependent diabetes mellitus. Am J Med 74: 52-81, 1983.

10. Dela F, Larsen JJ, Mikines KJ, Ploug T, Petersen LN, and Galbo H. Insulin-stimulated muscle glucose clearance in patients with NIDDM. Effects of one-legged physical training. Diabetes 44: 1010-1020, 1995.

11. Dela F, Mikines KJ, von Linstow M, Secher NH, and Galbo H. Effect of training on insulin-mediated glucose uptake in human muscle. Am J Physiol 263: E1134-1143, 1992.

12. Dela F, Ploug T, Handberg A, Petersen LN, Larsen JJ, Mikines KJ, and Galbo H. Physical training increases muscle GLUT4 protein and mRNA in patients with NIDDM. Diabetes 43: 862-865, 1994.

13. Derave W, Hansen BF, Lund S, Kristiansen S, and Richter EA. Muscle glycogen content affects insulin-stimulated glucose transport and protein kinase B activity. Am J Physiol Endocrinol Metab 279: E947-955, 2000.

14. Devlin JT, Hirshman M, Horton ED, and Horton ES. Enhanced peripheral and splanchnic insulin sensitivity in NIDDM men after single bout of exercise. Diabetes 36: 434-439, 1987.

15. Devlin JT and Horton ES. Effects of prior high-intensity exercise on glucose metabolism in normal and insulin-resistant men. Diabetes 34: 973-979, 1985.

16. Dumortier M, Brandou F, Perez-Martin A, Fedou C, Mercier J, and Brun JF. Low intensity endurance exercise targeted for lipid oxidation improves body composition and insulin sensitivity in patients with the metabolic syndrome. Diabetes Metab 29: 509-518, 2003. 
17. Dunstan DW, Daly RM, Owen N, Jolley D, De Courten M, Shaw J, and Zimmet P. High-intensity resistance training improves glycemic control in older patients with type 2 diabetes. Diabetes Care 25: 1729-1736, 2002.

18. Eriksson KF and Lindgarde F. Poor physical fitness, and impaired early insulin response but late hyperinsulinaemia, as predictors of NIDDM in middle-aged Swedish men. Diabetologia 39: 573-579, 1996.

19. Fenicchia LM, Kanaley JA, Azevedo JL, Jr., Miller CS, Weinstock RS, Carhart RL, and Ploutz-Snyder LL. Influence of resistance exercise training on glucose control in women with type 2 diabetes. Metabolism 53: 284-289, 2004.

20. Fluckey JD, Hickey MS, Brambrink JK, Hart KK, Alexander K, and Craig BW. Effects of resistance exercise on glucose tolerance in normal and glucose-intolerant subjects. J Appl Physiol 77: 1087-1092, 1994.

21. Fryer LG, Foufelle F, Barnes K, Baldwin SA, Woods A, and Carling D. Characterization of the role of the AMP-activated protein kinase in the stimulation of glucose transport in skeletal muscle cells. Biochem J 363: 167-174, 2002.

22. Garcia-Roves PM, Han DH, Song Z, Jones TE, Hucker KA, and Holloszy JO. Prevention of glycogen supercompensation prolongs the increase in muscle GLUT4 after exercise. Am J Physiol Endocrinol Metab 285: E729-736, 2003.

23. Goodpaster BH, Kelley DE, Wing RR, Meier A, and Thaete FL. Effects of weight loss on regional fat distribution and insulin sensitivity in obesity. Diabetes 48: 839-847, 1999.

24. Goodyear LJ and Kahn BB. Exercise, glucose transport, and insulin sensitivity. Annu Rev Med 49: 235-261, 1998.

25. Hayashi T, Hirshman MF, Fujii N, Habinowski SA, Witters LA, and Goodyear LJ. Metabolic stress and altered glucose transport: activation of AMP-activated protein kinase as a unifying coupling mechanism. Diabetes 49: 527-531, 2000.

26. Heath GW, Gavin JR, 3rd, Hinderliter JM, Hagberg JM, Bloomfield SA, and Holloszy JO. Effects of exercise and lack of exercise on glucose tolerance and insulin sensitivity. J Appl Physiol 55: 512-517, 1983.

27. Henriksen EJ. Invited review: Effects of acute exercise and exercise training on insulin resistance. J Appl Physiol 93: 788-796, 2002.

28. Hirst S, Phillips DI, Vines SK, Clark PM, and Hales CN. Reproducibility of the short insulin tolerance test. Diabet Med 10: 839-842, 1993.

29. Holten MK, Zacho M, Gaster M, Juel C, Wojtaszewski JF, and Dela F. Strength training increases insulin-mediated glucose uptake, GLUT4 content, and insulin signaling in skeletal muscle in patients with type 2 diabetes. Diabetes 53: 294-305, 2004.

30. Houmard JA, Tanner CJ, Yu C, Cunningham PG, Pories WJ, MacDonald KG, and Shulman GI. Effect of weight loss on insulin sensitivity and intramuscular long-chain fatty acyl-CoAs in morbidly obese subjects. Diabetes 51: 2959-2963, 2002.

31. Hu FB, Manson JE, Stampfer MJ, Colditz G, Liu S, Solomon CG, and Willett WC. Diet, lifestyle, and the risk of type 2 diabetes mellitus in women. N Engl J Med 345: 790-797, 2001.

32. Hughes VA, Fiatarone MA, Fielding RA, Kahn BB, Ferrara CM, Shepherd P, Fisher EC, Wolfe RR, Elahi D, and Evans WJ. Exercise increases muscle GLUT-4 levels and insulin action in subjects with impaired glucose tolerance. Am J Physiol 264: E855-862, 1993.

33. Hundal RS, Krssak M, Dufour S, Laurent D, Lebon V, Chandramouli V, Inzucchi SE, Schumann WC, Petersen KF, Landau BR, and Shulman GI. Mechanism by which 
metformin reduces glucose production in type 2 diabetes. Diabetes 49: 2063-2069, 2000.

34. Inzucchi SE, Maggs DG, Spollett GR, Page SL, Rife FS, Walton V, and Shulman GI. Efficacy and metabolic effects of metformin and troglitazone in type II diabetes mellitus. N Engl J Med 338: 867-872, 1998.

35. Ishii T, Yamakita T, Sato T, Tanaka S, and Fujii S. Resistance training improves insulin sensitivity in NIDDM subjects without altering maximal oxygen uptake. Diabetes Care 21: 1353-1355, 1998.

36. Kahn SE, Larson VG, Beard JC, Cain KC, Fellingham GW, Schwartz RS, Veith RC, Stratton JR, Cerqueira MD, and Abrass IB. Effect of exercise on insulin action, glucose tolerance, and insulin secretion in aging. Am J Physiol 258: E937-943, 1990.

37. Ko GT, Chan JC, Woo J, Lau E, Yeung VT, Chow CC, and Cockram CS. The reproducibility and usefulness of the oral glucose tolerance test in screening for diabetes and other cardiovascular risk factors. Ann Clin Biochem 35 (Pt 1): 62-67, 1998.

38. Kraemer WJ and Fry AC. Strength Testing; Development and Evaluation of Methodology. In: Physiological Assesment of Human Fitness, edited by Maud PJ and Foster C. Leeds: Human Kinetics, 1995, p. 115-133.

39. Kraniou Y, Cameron-Smith D, Misso M, Collier G, and Hargreaves M. Effects of exercise on GLUT-4 and glycogenin gene expression in human skeletal muscle. J Appl Physiol 88: 794-796, 2000.

40. Matthews DR, Hosker JP, Rudenski AS, Naylor BA, Treacher DF, and Turner RC. Homeostasis model assessment: insulin resistance and beta-cell function from fasting plasma glucose and insulin concentrations in man. Diabetologia 28: 412-419, 1985.

41. Mayhew JL, Piper FC, and Ware JS. Anthropometric correlates with strength performance among resistance trained athletes. J Sports Med Phys Fitness 33: 159-165, 1993.

42. Mikines KJ, Sonne B, Farrell PA, Tronier B, and Galbo H. Effect of physical exercise on sensitivity and responsiveness to insulin in humans. Am J Physiol 254: E248-259, 1988.

43. Miller WJ, Sherman WM, and Ivy JL. Effect of strength training on glucose tolerance and post-glucose insulin response. Med Sci Sports Exerc 16: 539-543, 1984.

44. Mokdad AH, Bowman BA, Ford ES, Vinicor F, Marks JS, and Koplan JP. The continuing epidemics of obesity and diabetes in the United States. Jama 286: 1195 1200, 2001.

45. Niskanen L, Uusitupa M, Sarlund H, Siitonen O, Paljarvi L, and Laakso M. The effects of weight loss on insulin sensitivity, skeletal muscle composition and capillary density in obese non-diabetic subjects. Int J Obes Relat Metab Disord 20: 154-160, 1996.

46. Perseghin G, Price TB, Petersen KF, Roden M, Cline GW, Gerow K, Rothman DL, and Shulman GI. Increased glucose transport-phosphorylation and muscle glycogen synthesis after exercise training in insulin-resistant subjects. N Engl J Med 335: 13571362, 1996.

47. Pichon C, Hunter GR, Morris M, Bond RL, and Metz J. Blood pressure and heart rate response and metabolic cost of circuit versus traditional weight training. J Strength Cond Res 10: 153-156, 1996.

48. Rogers MA, Yamamoto C, King DS, Hagberg JM, Ehsani AA, and Holloszy JO. Improvement in glucose tolerance after $1 \mathrm{wk}$ of exercise in patients with mild NIDDM. Diabetes Care 11: 613-618, 1988.

49. Saltiel AR and Olefsky JM. Thiazolidinediones in the treatment of insulin resistance and type II diabetes. Diabetes 45: 1661-1669, 1996. 
50. Siri WE. The gross composition of the body. Adv Biol Med Physiol 4: 238-280, 1956.

51. Smutok MA, Reece C, Kokkinos PF, Farmer C, Dawson P, Shulman R, DeVane-Bell J, Patterson J, Charabogos C, Goldberg AP, and et al. Aerobic versus strength training for risk factor intervention in middle-aged men at high risk for coronary heart disease. Metabolism 42: 177-184, 1993.

52. Smutok MA, Reece C, Kokkinos PF, Farmer CM, Dawson PK, DeVane J, Patterson J, Goldberg AP, and Hurley BF. Effects of exercise training modality on glucose tolerance in men with abnormal glucose regulation. Int J Sports Med 15: 283-289, 1994.

53. Thorell A, Hirshman MF, Nygren J, Jorfeldt L, Wojtaszewski JF, Dufresne SD, Horton ES, Ljungqvist O, and Goodyear LJ. Exercise and insulin cause GLUT-4 translocation in human skeletal muscle. Am J Physiol 277: E733-741, 1999.

54. van Loon LJ. Use of intramuscular triacylglycerol as a substrate source during exercise in humans. J Appl Physiol 97: 1170-1187, 2004.

55. Winder WW. Energy-sensing and signaling by AMP-activated protein kinase in skeletal muscle. J Appl Physiol 91: 1017-1028, 2001.

56. Wojtaszewski JF, Hansen BF, Gade, Kiens B, Markuns JF, Goodyear LJ, and Richter EA. Insulin signaling and insulin sensitivity after exercise in human skeletal muscle. Diabetes 49: 325-331, 2000.

57. Wojtaszewski JF, Hansen BF, Kiens B, and Richter EA. Insulin signaling in human skeletal muscle: time course and effect of exercise. Diabetes 46: 1775-1781, 1997.

58. Yki-Jarvinen $\mathrm{H}$ and Koivisto VA. Effects of body composition on insulin sensitivity. Diabetes 32: 965-969, 1983. 



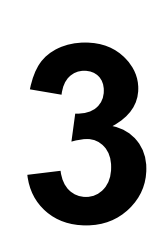

\section{Intramyocellular lipid and glycogen content are reduced following resistance exercise in untrained healthy males}

René Koopman, Ralph J.F. Manders, Richard A.M. Jonkers, Gabby B.J. Hul, Harm Kuipers, and Luc J.C. van Loon

Eur J Appl Physiol (2006). 96:525-534 


\begin{abstract}
Resistance exercise has recently been shown to improve whole-body insulin sensitivity in healthy males. Whether this is accompanied by an exercise-induced decline in skeletal muscle glycogen and/or lipid content remains to be established. In the present study, we determined fiber-type specific changes in skeletal muscle substrate content following a single resistance exercise session. After an overnight fast, eight untrained healthy lean males participated in a $\sim 45$ min resistance exercise session. Muscle biopsies were collected before, following cessation of exercise, and after 30 and 120 min of post-exercise recovery. Subjects remained fasted throughout the test. Conventional light and (immuno)fluorescence microscopy were applied to assess fiber-type specific changes in intramyocellular triacylglycerol (IMTG) and glycogen content. A significant $27 \pm 7 \%$ net decline in IMTG content was observed in the type I muscle fibers $(P<0.05)$, with no net changes in the type IIa and IIx fibers. Muscle glycogen content decreased with $23 \pm 6,40 \pm 7$ and $44 \pm 7 \%$ in the type I, IIa and IIx muscle fibers, respectively $(\mathrm{P}<0.05)$. Fiber-type specific changes in intramyocellular lipid and/or glycogen content correlated well with muscle fiber-type oxidative capacity. During postexercise recovery, type I muscle fiber lipid content returned to pre-exercise levels within $120 \mathrm{~min}$. No changes in muscle glycogen content were observed during recovery. We conclude that intramyocellular lipid and glycogen stores are readily used during resistance exercise and this is likely associated with the reported increase in whole-body insulin sensitivity following resistance exercise.
\end{abstract}




\section{Introduction}

Fat and carbohydrate are the principal substrates that fuel ATP resynthesis in skeletal muscle tissue. Endogenous carbohydrates are mainly stored as muscle and liver glycogen and represent less than $5 \%$ of total energy storage. The vast majority of our energy reserves is stored as fat, mainly deposited as triacylglycerol (TG) in subcutaneous and deep visceral adipose tissue. Smaller quantities of TG are present as lipid droplets inside the muscle fibers, intramyocellular triacylglycerol (IMTG) (19).

There has been much controversy on the actual contribution of the IMTG pool as a substrate source during exercise (47). The apparent discrepancy in the literature likely stems from the methodological difficulties that have been associated with the biochemical triacylglycerol extraction method that has been used to determine IMTG content in muscle biopsies collected before and after exercise (47). In accordance, more recent studies using stable isotope methodology, ${ }^{1} \mathrm{H}$-magnetic resonance spectroscopy, electron and/or immunofluorescence microscopy all support the contention that the IMTG pool can function as an important substrate source during submaximal exercise (45). Besides the intramyocellular lipid deposits, muscle glycogen stores represent another important substrate source. In accordance, substantial net reductions in both type I and II muscle fiber glycogen content have been reported following prolonged endurance exercise tasks (42). These intramyocellular lipid and glycogen stores play a major regulatory role in skeletal muscle metabolism. Muscle glycogen use and subsequent post-exercise glycogen synthesis rates have been shown to be functionally coupled to the exercise-induced increase in skeletal muscle insulin sensitivity in humans and rodents $(2,6,14,35,48,49)$. Furthermore, interventions known to improve insulin sensitivity, like weight loss in humans $(15,20)$, dietary lipid withdrawal (33), the use of thiazolidinediones in rodents (34) as well as an acute bout of endurance exercise in rodents and humans $(33,45)$ have all been associated with a reduction in skeletal muscle lipid content. Because of its capacity to reduce both intramyocellular lipid and glycogen content, endurance exercise is generally considered an effective interventional strategy to improve skeletal muscle insulin sensitivity.

However, resistance exercise should also be regarded as an essential component of effective intervention programs designed to improve health. Resistance training increases skeletal muscle mass (22) and, as such, can augment whole-body glucose disposal capacity $(5,11,31)$. In addition, resistance training also improves muscle strength, power and functional capacity, which facilitates the adaptation towards a more active lifestyle $(10,28)$. Though there is some discrepancy in the existing literature, we $(24)$ as well as others $(11,12)$ have recently shown that even a single resistance exercise session can improve whole-body insulin sensitivity for up to $24 \mathrm{~h}$ after cessation of exercise. In line with the acute stimulating effects of endurance exercise on post-exercise insulin sensitivity (2), it has been speculated that the acute effects of resistance exercise on whole-body insulin sensitivity are also attributed to the reduction of the intramyocellular glycogen and/or lipid stores 
(24). However, studies on the metabolic demands of resistance exercise are scarce, which is likely due to the methodological difficulties associated with the non-steady state conditions of this type of exercise. Therefore, in the present study, we determined fiber-type specific changes in intramyocellular glycogen and lipid content during and immediately after a single resistance exercise session.

\section{Methods}

\section{Subjects}

Eight healthy untrained male volunteers with no history of participating in any regular exercise program were recruited for the present study. Subjects' characteristics are shown in table 1. All subjects were informed on the nature and possible risks of the experimental procedures before their written informed consent was obtained, the latter after approval by the Medical Ethical Committee of the Academic Hospital Maastricht.

Table 3.1 subjects' characteristics

\begin{tabular}{lc}
\hline & Mean \pm SEM \\
\hline Age (yrs) & $22.5 \pm 0.9$ \\
Weight (kg) & $74.9 \pm 2.8$ \\
Height (m) & $1.80 \pm 0.01$ \\
BMI (kg.m-2) & $23.3 \pm 0.7$ \\
$\%$ bodyfat (\%) & $17.8 \pm 2.4$ \\
Fat free mass (kg) & $61.3 \pm 2.1$ \\
Fat mass (kg) & $13.6 \pm 2.1$ \\
HbA 1 ( $\%)$ & $5.3 \pm 0.1$ \\
1RM leg press $(\mathrm{kg})$ & $198 \pm 7$ \\
1RM leg extension $(\mathrm{kg})$ & $105 \pm 3$ \\
\hline
\end{tabular}

Values are expressed as means \pm SEM.

\section{Pretesting}

Body composition was assessed using the hydrostatic weighing method in the morning following an overnight fast. Residual lung volume was measured by the helium-dilution technique using a spirometer (Volugraph 2000, Mijnhart, Bunnik, The Netherlands). Body mass was measured with a digital balance with an accuracy of $0.001 \mathrm{~kg}$ (E1200, August Sauter GmbH, Albstadt, Germany). Body fat percentage was calculated using Siri's equation (39). Fat Free mass (FFM) was calculated by subtracting fat mass from total body mass.

To familiarize subjects with the resistance exercise protocol and the equipment, a familiarization trial was performed. Proper lifting technique was demonstrated and practiced for each of the 2 lower-limb exercises (leg-press and leg-extension) and for the 3 upper-body exercises (chest-press, shoulder-press and lat-pulldown). Thereafter, maximum strength was estimated using the multiple repetitions testing procedure (29). 
In an additional exercise session, at least 1 wk before the first experimental trial, the subjects' 1 repetition maximum (1RM) was determined (26). After warming up, the load was set at $90-95 \%$ of the estimated $1 \mathrm{RM}$, and increased after each successful lift until failure. A 5 min resting period between subsequent attempts was allowed. A repetition was valid if the subject was able to complete the entire lift in a controlled manner without assistance.

\section{Standardised diet and activity prior to testing}

All subjects received a strict standardized diet for 2 days prior to the resistance exercise test trial, which was performed in the morning after an overnight fast. Subjects were provided with a pre-weighed amount of food products, beverages, and instant meals and were allowed to drink water ad libitum. Subjects were instructed to take all main meals (breakfast, lunch, and dinner) and between-meal snacks at predetermined time intervals during each day. The standardized diet provided $0.15 \mathrm{MJ} \cdot \mathrm{kg}^{-1} \cdot \mathrm{day}^{-1}$ containing $15 \mathrm{Energy} \%(\mathrm{En} \%)$ of protein, $30 \mathrm{En} \%$ of fat and $55 \mathrm{En} \%$ of carbohydrate. All volunteers were instructed to refrain from any sort of heavy physical exercise during the 2 days prior to the test-trial.

\section{Experimental trial}

The day of the test, subjects arrived at the laboratory by car or public transportation at $8.00 \mathrm{am}$, following an overnight fast. A Teflon catheter was inserted into an antecubital vein for blood sampling. After 30 min of supine rest, a basal blood sample was collected and a muscle biopsy was taken from the $\mathrm{m}$. vastus lateralis. Thereafter, subjects performed a 5 min low-intensity warm-up on a Stairmaster, followed by 3 sets of 10 repetitions on 3 resistance exercise machine targeting upper-body muscle groups (chest-press, shoulder-press and lat-pulldown, Jimsa Benelux BV, Rotterdam, The Netherlands). The latter were included to provide a whole-body warm-up to reduce the risk of injury. Thereafter, subjects performed 8 sets of 10 repetitions on the horizontal leg-press machine (Technogym BV, Rotterdam, The Netherlands) and 8 sets of 10 repetitions on the leg-extension machine (Technogym). Both exercises were performed at $75 \%$ of the individual $1 \mathrm{RM}$ with $2 \mathrm{~min}$ rest intervals between sets and required $\sim 45 \mathrm{~min}$ to complete. All subjects were verbally encouraged during the exercise session to complete the entire protocol. Immediately after cessation of exercise, a second muscle biopsy sample was taken, after which subjects rested supine for $2 \mathrm{~h}$. After $30 \mathrm{~min}$ and $2 \mathrm{~h}$ of post-exercise recovery, additional muscle biopsies were taken. Blood samples were collected before, after $30 \mathrm{~min}$ of exercise, immediately after cessation of exercise and following 30, 60, 90 and $120 \mathrm{~min}$ of post-exercise recovery. Subjects remained fasted throughout the test.

Muscle biopsy samples were collected from both legs. The first two biopsies were taken from the same incision in one leg; the last two were taken from the same incision in the contralateral leg. When biopsy samples were taken from the same incision, the first sample was taken from a different region (distal of the incision, 
with the needle pointing inwards) than the second (proximal with the needle pointing outwards). Muscle biopsies were obtained from the middle region of the $\mathrm{m}$. vastus lateralis $(15 \mathrm{~cm}$ above the patella) and approximately $3 \mathrm{~cm}$ below entry through the fascia using the percutaneous needle biopsy technique (1). Muscle samples were dissected carefully, freed from any visible non-muscle material, embedded in Tissue-Tek (Sakura Finetek, Zoeterwoude, The Netherlands) and rapidly frozen in liquid nitrogen-cooled isopentane.

\section{Plasma sample analysis}

Blood samples $(6 \mathrm{ml})$ were collected in EDTA-containing tubes and centrifuged at $1000 \mathrm{~g}$ at $4^{\circ} \mathrm{C}$ for $10 \mathrm{~min}$. Aliquots of plasma were frozen immediately in liquid nitrogen and stored at $-80^{\circ} \mathrm{C}$. Plasma glucose (Uni Kit III, Roche, Basel, Switzerland), lactate (Gutmann \& Wahlefeld, 1974) and FFA (Wako NEFA-C test kit, Wako Chemicals, Neuss, Germany) concentrations were analysed with a COBAS FARA semi-automatic analyser (Roche).

\section{Muscle sample analysis}

Multiple serial sections $(5 \mu \mathrm{m})$ from biopsy samples collected before, immediately after, 30 and 120 min after exercise were thaw-mounted together on uncoated, precleaned glass slides for each subject. To permit the determination of muscle fiber IMTG content stained by oil red $\mathrm{O}$ together with immunolabelled cellular constituents we used the protocol as previously described $(25,44-46)$. The proportion of type I, IIa, and IIx muscle fibers was determined by ATPase staining (27). To assess intramyocellular glycogen content we used the modified Periodic Acid Schiff reagent stain (PAS) as recently described (37), allowing direct, fibertype-specific determination of muscle glycogen content. Muscle fiber-type specific oxidative capacity was estimated by determining succinate dehydrogenase activity $(\mathrm{SDH})$ in the muscle cross-sections using histochemical analyses (16). Histological techniques, like oil red $\mathrm{O}$, PAS and SDH staining combined with either immunofluorescence or conventional light microscopy are semi-quantitative. As a consequence, the present study does not provide absolute measures of skeletal muscle lipid and/or glycogen concentrations. After 24h, glass slides were examined using a Nikon E800 fluorescence microscope (Uvikon, Bunnik, The Netherlands) coupled to a Basler A113 C progressive scan color CCD camera, with a Bayer color filter. Epifluorescence signal was recorded using a Texas red excitation filter (540-580 nm) for oil red O, a fluorescein isothiocyanate (FITC) excitation filter $(465-495 \mathrm{~nm})$ for muscle fiber-type, and a 4',6-diamidino-2-phenylindole (DAPI) UV excitation filter (340-380 nm) for laminin.

Digitally captured images (240x magnification) with a minimum of six fields-ofview per muscle cross-section (12 \pm 1 fibers per field-of-view), were processed and analyzed using Lucia 4.8 software (Nikon, Düsseldorf, Germany). The signal derived from the antibody against laminin was used to select single muscle fibers and with the antibody against human myosin heavy chain I, we were able to 
differentiate between type I and II muscle fibers. To differentiate between type IIa and IIx fibers we used matching serial cross-section stained using routine ATPase staining. The oil red $\mathrm{O}$ epifluorescence signal was recorded for each muscle fiber, resulting in a total of $70 \pm 5$ muscle fibers analyzed for each muscle cross-section (35 \pm 2 type I, $25 \pm 4$ type IIa and $10 \pm 1$ type IIx muscle fibers). An intensity threshold representing minimal intensity values corresponding to lipid droplets was set manually and uniformly used for all images. Total area measured and the area as well as the number of objects emitting oil red $\mathrm{O}$ epifluorescence signal were recorded. Fiber-type-specific IMTG content was expressed as the percentage of the measured area that was stained with oil red O. In a previous study, two different muscle samples from two different subjects were analysed; showing a coefficient of variance of 10.5 and $38.6 \%$ for the type I and II muscle fibers (45). Mixed muscle fiber lipid content, as determined by oil red $\mathrm{O}$ staining, has been shown to correlate significantly with measures of intramyocellular lipid content as assessed by ${ }^{1} \mathrm{H}$-magnetic resonance spectroscopy (46). Average lipid droplet size was calculated by dividing the total area lipid stained by total number of lipid droplets. Lipid droplet density was calculated by dividing the total number of lipid droplets by the total area measured.

PAS and SDH stained sections were captured in full color using bright field light microscopy. Digitally captured images (120x magnification) with a minimum of four fields-of-view per muscle cross-section ( $37 \pm 2$ fibers per field-of-view), were processed and analyzed using the Lucia 4.8 software package. The PAS and SDH signals were recorded for each muscle fiber, resulting in a total of $142 \pm 8$ muscle fibers analyzed for each muscle cross-section (64 \pm 4 type I, $57 \pm 5$ type IIa and $21 \pm 2$ typ IIx muscle fibers). The bright-field images of the PAS and SDH stains were converted post hoc to 8-bit grayscale values. The mean optical density of the PAS or SDH-raised signal per individual fiber was determined by averaging the optical density measured in every pixel in the cell, corrected for the mean optical density of the background stain measured in a field-of-view containing no muscle fibers. Mixed muscle glycogen content, as determined by PAS staining, correlates significantly with muscle glycogen content as measured using biochemical analyses (37).

\section{Statistics}

All data are expressed as means \pm SEM. Analyses of variance (ANOVA) for repeated measures were applied to determine differences in muscle lipid and glycogen content over time in type I, IIa and IIx fibers with time and muscle fibertype as factors. In case of a significant F-ratio, a Scheffé post-hoc test was applied to locate the differences. Statistical significance was set at $\mathrm{P}<0.05$. Simple regression analysis was performed on mean muscle fiber-type oxidative capacity and glycogen/lipid content. 


\section{Results}

\section{Resistance exercise}

Mean 1 repetition maximum (1RM) measured during the pre-test was $198 \pm 7 \mathrm{~kg}$ on the horizontal leg press and $105 \pm 3 \mathrm{~kg}$ on the leg extension. Therefore, average weight lifted during the resistance exercise was set at $148 \pm 5$ and $79 \pm 3 \mathrm{~kg}$ for the leg press and leg extension respectively. All subjects completed 8 sets with 10 repetitions on the leg press. One subject was unable to finish 10 repetitions during the 6th set, after which resistance was reduced to $65 \%$ of the individual 1RM. All subjects completed 8 sets of 10 repetitions on the leg extension machine.

\section{Plasma analyses}

Plasma glucose, lactate and FFA concentrations are presented in figure 3.1. Plasma glucose concentrations increased during exercise and peaked immediately postexercise $(\mathrm{P}<0.05)$, after which they returned to baseline values. Plasma lactate concentrations markedly increased during exercise $(\mathrm{P}<0.0001)$, and decreased during recovery. Plasma FFA concentrations tended to decrease during exercise $(\mathrm{P}=0.08)$, and markedly increased during recovery $(\mathrm{P}<0.001)$.

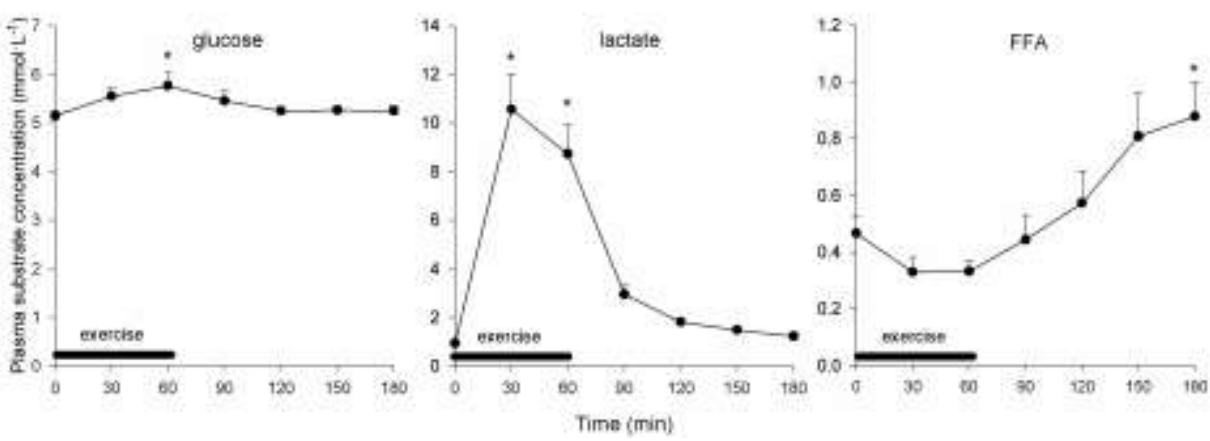

Figure 3.1 Plasma glucose, lactate and free fatty acid concentrations at rest, during resistance exercise and subsequent recovery. Data provided are means \pm SEM. * Significantly different from pre-exercise values $(\mathrm{P}<0.05)$

\section{Muscle glycogen content}

Representative images of muscle cross-sections obtained before (A) and immediately after (B) exercise following PAS staining for analyses of intramyocellular glycogen content are shown in figure 3.2. Muscle fiber glycogen content was similar at rest in all fiber-types. Mixed muscle glycogen content declined by $33 \pm 7 \%$ following the exercise session $(\mathrm{P}<0.0001)$. Glycogen content had declined by $23 \pm 6 \%$ in the type I fibers $(\mathrm{P}<0.01), 40 \pm 7 \%$ in the type IIa fibers $(\mathrm{P}<0.001)$, and $44 \pm 7 \%$ in the type IIx fibers $(\mathrm{P}<0.001)$ compared to pre-exercise values (figure 3.3). The observed decrease over time in glycogen content was 
significantly greater in the type IIx fibers compared to the type I muscle fibers $(\mathrm{P}<0.05)$. During post-exercise recovery muscle glycogen content remained below pre-exercise levels, with no significant changes over time in the type I, IIa and IIx muscle fibers.
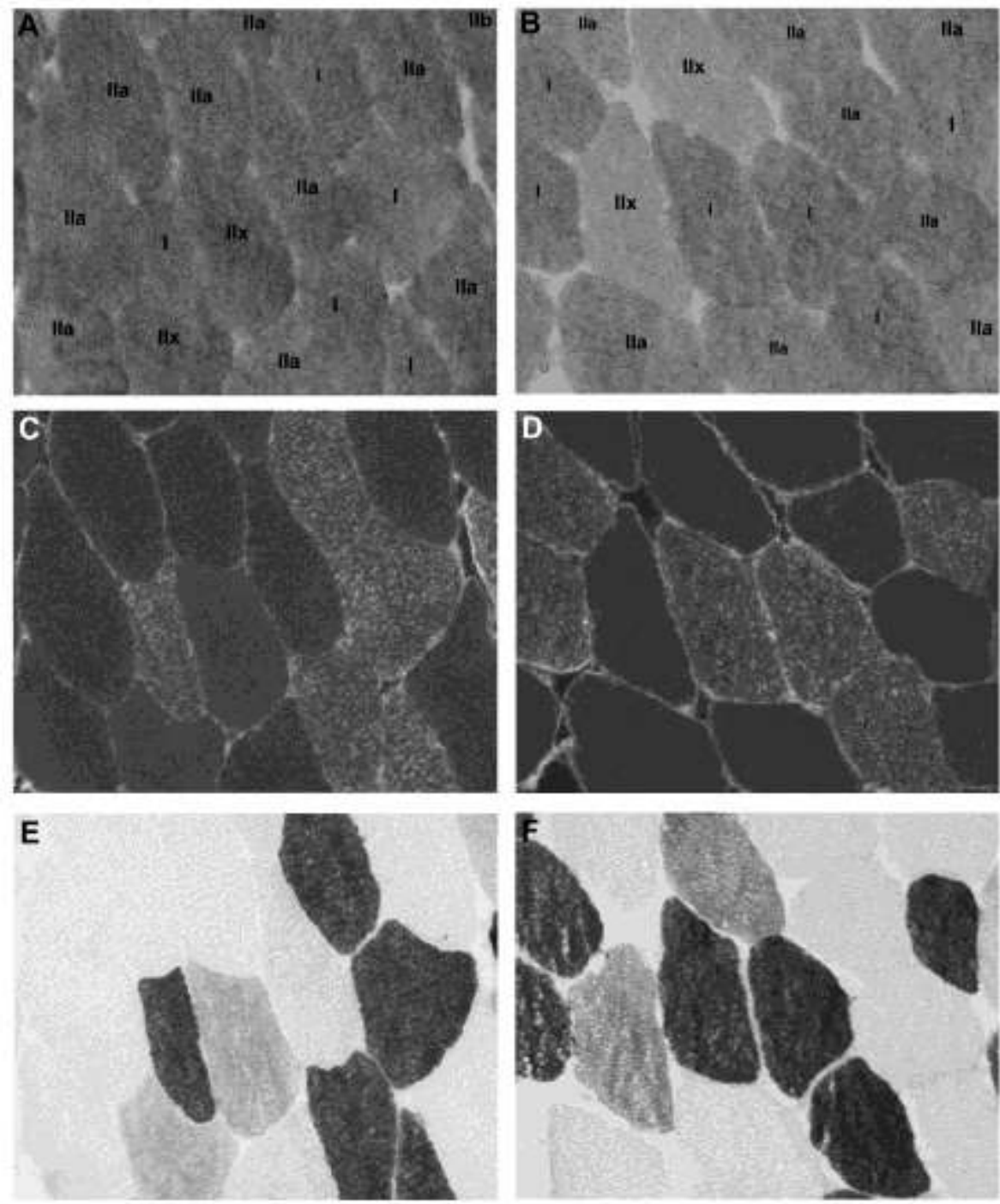

Figure 3.2 Images (120x magnification) of representative cross-sections of vastus lateralis muscle obtained before (left) and immediately after exercise (right) with sections stained for glycogen content (A/B), and laminin and myosin heavy chains I (C/D). The muscle fibers are labeled as type I, type IIa, and type IIx. Differentiation between type IIa and IIx fibers was made based on ATPase staining (E/F). 


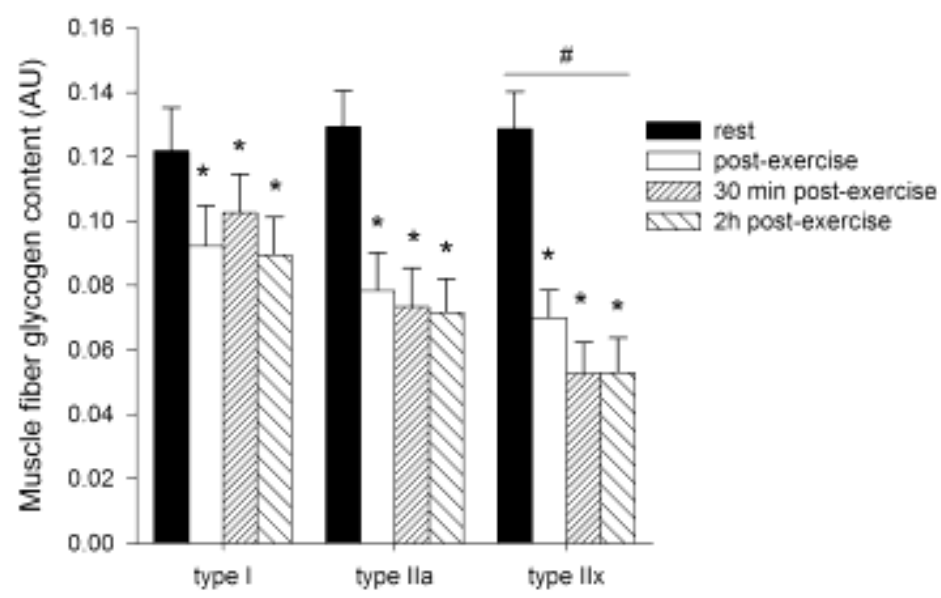

Figure 3.3 The effect of resistance exercise on muscle glycogen content. Fiber-type specific glycogen content (expressed in arbitrary units) before and immediately after exercise, and following 30 and 120 min of post-exercise recovery as determined by brightfield microscopy on PAS-stained muscle cross-sections. Data provided are means \pm SEM. * Significantly lower than pre-exercise values $(\mathrm{P}<0.05)$; \# significantly different over time compared to type I muscle fibers $(\mathrm{P}<0.05)$.

\section{IMTG content}

Representative images of muscle cross-sections obtained before (A) and immediately after (B) exercise stained for intramyocellular lipid content are shown in figure 3.4. Muscle tissue analyses for IMTG content applying fluorescence microscopy on oil red $\mathrm{O}$ stained muscle cross-sections showed that at rest IMTG content in type I fibers was higher compared with type II fibers $(\mathrm{P}<0.05)$. Mixed muscle IMTG content tended to decline with $25 \pm 10 \%$ following the exercise session $(\mathrm{P}=0.087)$. In addition, a substantial $27 \pm 7 \%$ decline in lipid content in the type I fibers $(\mathrm{P}<0.05)$ was found, with IMTG content in the type I muscle fibers being significantly lower both immediately post-exercise as well as following 30 min of post-exercise recovery compared to pre-exercise values (figure 3.5). After $2 \mathrm{~h}$ of post-exercise recovery, IMTG content had returned to values similar to preexercise values. The observed decrease in IMTG content was accounted for by a significant decrease in lipid droplet size (from $0.69 \pm 0.08$ to $0.53 \pm 0.07$ and $0.53 \pm 0.07 \mathrm{~m}^{2}, \mathrm{P}<0.01$ ) without any changes in lipid droplet density (from $0.049 \pm 0.003$ to $0.045 \pm 0.004$ and $0.041 \pm 0.003$ droplets $\mu \mathrm{m}^{-2}$ ) as determined before, immediately after and after $30 \mathrm{~min}$ of post-exercise recovery exercise, respectively. Net changes in IMTG content over time in the type I fibers were significantly different compared to the type IIa and IIx fibers $(\mathrm{P}<0.05)$. No significant changes over time were observed in intramyocellular lipid content in the type IIa or IIx muscle fibers. 

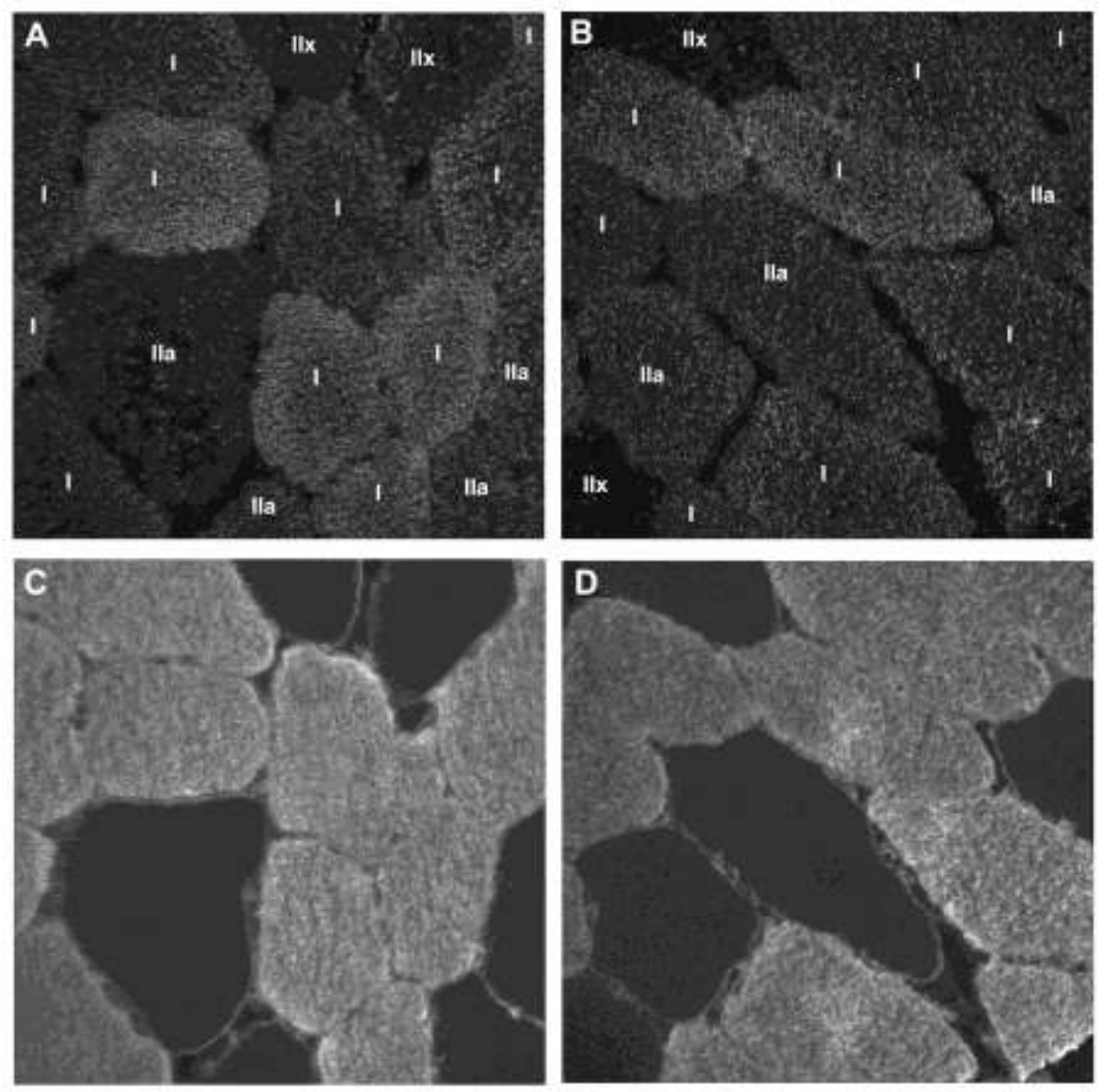

Figure 3.4. Images (240x magnification) of representative cross-sections of vastus lateralis muscle obtained before (left) and immediately after exercise (right) with sections stained for lipid content (A/B), and laminin and myosin heavy chains (C/D). The muscle fibers are labeled as type I, type IIa, and type IIx. Differentiation between type IIa and IIx fibers was made, based on standard ATPase staining.

\section{Muscle fiber oxidative capacity}

A histochemical analysis for succinate dehydrogenase (SDH) activity in muscle cross-sections was performed as a measure of muscle fiber oxidative capacity and results are shown in table 3.2. SDH activity was significantly greater in the type I versus the type II fibers $(\mathrm{P}<0.05)$. Type IIa muscle fiber SDH activity was substantially greater when compared to the IIx fibers $(\mathrm{P}<0.05)$. Positive correlations were observed between muscle fiber-type oxidative capacity and baseline muscle fiber lipid content $(\mathrm{r}=0.573, \mathrm{P}<0.01)$, and muscle fiber-type oxidative capacity and the net reduction in muscle fiber lipid content observed following exercise $(\mathrm{r}=0.482, \mathrm{P}<0.05)$. No significant correlation was observed between muscle fiber-type specific oxidative capacity and resting muscle fiber glycogen content. A significant negative correlation was observed between muscle 
fiber-type oxidative capacity and the net reduction in muscle fiber glycogen content observed during exercise $(\mathrm{r}=-0.556, \mathrm{P}<0.05)$.

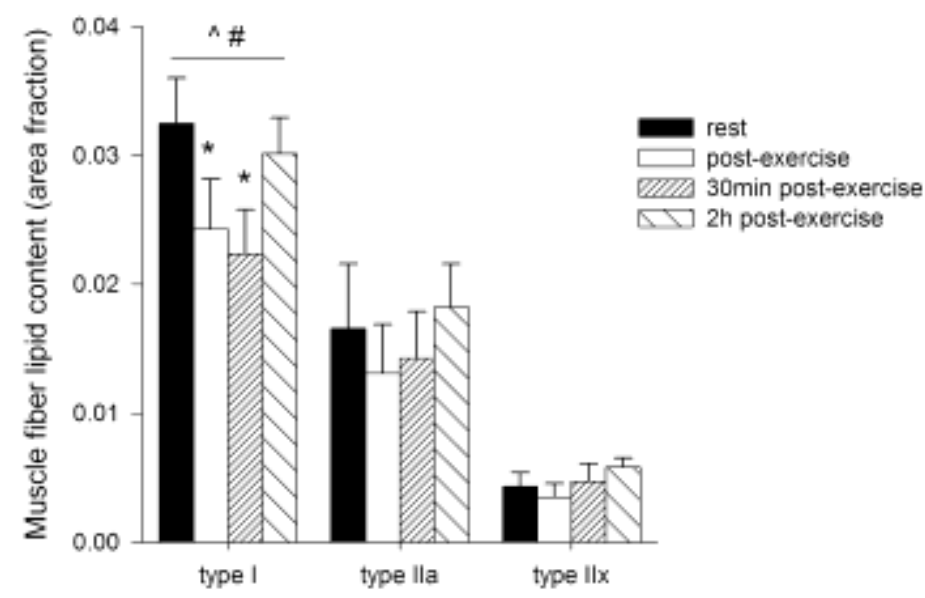

Figure 3.5 The effect of resistance exercise on muscle lipid content. Mean fiber-type-specific intramyocellular lipid content (expressed as percentage of area lipid stained) before exercise, immediately after exercise and following 30 and $120 \mathrm{~min}$ of post-exercise recovery as determined by fluorescence microscopy on oil red $\mathrm{O}$ stained muscle cross-sections Data provided are means \pm SEM. $*$ : significantly lower than pre-exercise values $(\mathrm{P}<0.05)$; \#: significantly different over time compared to type IIa fibers $(\mathrm{P}<0.05) ;{ }^{\wedge}$ : significantly different over time compared to type IIx fibers $(\mathrm{P}<0.05)$.

Table 3.2 Muscle SDH activity, glycogen and lipid content at rest

\begin{tabular}{lccc}
\hline & Type I & Type IIa & Type IIx \\
\hline Fiber-type distribution (\%) & $46 \pm 4$ & $39 \pm 3$ & $15 \pm 2$ \\
SDH activity (AU) & $73 \pm 6$ & $45 \pm 5 *$ & $27 \pm 5 * \#$ \\
IMTGcontent (area fraction) & $0.032 \pm 0.004$ & $0.017 \pm 0.005 *$ & $0.004 \pm 0.001 *^{*}$ \\
Glycogen content (AU) & $0.122 \pm 0.038$ & $0.129 \pm 0.032$ & $0.129 \pm 0.032$ \\
Lipid content / SDH activity & $0.47 \pm 0.07$ & $0.42 \pm 0.13$ & $0.19 \pm 0.05$ \\
Glycogen content / SDH activity & $1.85 \pm 0.41$ & $3.41 \pm 0.85$ & $6.74 \pm 1.87 * \#$ \\
\hline
\end{tabular}

Values are expressed as means \pm SEM. * Significantly different from type I fibers $(\mathrm{P}<0.05)$, \# significantly different from type IIa fibers $(\mathrm{P}<0.05), \wedge$ different from type IIa fibers $(\mathrm{P}=0.07)$. AU Arbitrary Units.

\section{Discussion}

In the present study, we show that resistance exercise can substantially reduce skeletal muscle glycogen and lipid content. A single resistance exercise session reduces both type I and II muscle fiber glycogen content, with most pronounced changes located in the type IIx fibers. Furthermore, resistance exercise also reduces intramyocellular lipid content, which is restricted to the type I muscle fibers. Fibertype specific substrate utilisation during resistance exercise seems to be tightly coupled to muscle fiber-type oxidative capacity. 
The exercise-induced reduction in skeletal muscle glycogen and/or lipid content has been associated with an increase in insulin sensitivity in humans $(2,35,48,49)$. Numerous studies have reported intramuscular substrate availability to play a key regulatory role in skeletal muscle insulin signaling $(18,50)$. For example, skeletal muscle glucose uptake and glycogen synthase activity strongly depend on muscle glycogen availability $(32,50)$. The mechanism for this phenomenon is related to increased GLUT4 translocation under reduced muscle glycogen availability, and is likely coupled to an increased activation of AMP-activated protein kinase (AMPK) (50). Furthermore, a decrease in muscle lipid content following exercise has also been linked to greater insulin sensitivity in rodents (33). Although a variety of mechanisms have been suggested, recent studies seem to indicate that the relationship between IMTG content and skeletal muscle insulin sensitivity is not functional (44).

Aging, disability and functional incapacity often result in the inability/inefficacy to perform moderate-intensity endurance exercise. Therefore, resistance exercise training is now more frequently advocated as a necessary component of effective exercise intervention programs to augment muscle mass (22), strength, power and functional capacity $(10,28)$. However, only few studies have investigated the acute effects of resistance exercise on insulin sensitivity $(4,11,12)$. Recently, we showed that a single resistance exercise session improves whole-body insulin sensitivity by $\sim 13 \%$ for up to $24 \mathrm{~h}$ after exercise (24). The latter seems to be of a similar magnitude as the $\sim 20 \%$ increase in whole-body insulin sensitivity that has been reported after $\sim 60 \mathrm{~min}$ of endurance exercise $(7,8,30,35)$. It could be speculated that the increase in insulin sensitivity following resistance exercise is also associated with a net reduction in skeletal muscle glycogen and/or lipid content. However, literature on the metabolic demands of resistance exercise is scarce. Early reports suggest that energy needs during resistance exercise can be provided with only minor activation of glycogenolysis or lipolysis (23).

In the present study, we investigated fiber-type specific changes in skeletal muscle glycogen and lipid content following resistance exercise and subsequent recovery by using semi-quantitative histological techniques. The latter provides an effective strategy to assess fiber-type specific changes in intramyocellular lipid and/or glycogen content, without the methodological limitations associated with biochemical extraction analyses. In accordance, we recently reported a good correlation between IMTG content as determined by ${ }^{1} \mathrm{H}$-magnetic resonance spectroscopy (MRS) and fluorescence microscopy (45). In addition, strong correlations between data on (mixed-muscle) glycogen content obtained by the use of both biochemical and histochemical methods have recently been reported (37). In the present study, mixed muscle glycogen content declined by $33 \pm 7 \%$ following the resistance exercise session. The latter seems to be in line with previous studies applying biochemical analysis on mixed muscle tissue $(9,41)$. We extent their findings by showing that these changes in muscle glycogen are fiber-type specific, and seem to be tightly coupled to (non-)oxidative capacity (table 3.2, figure 3.3). Linear regression revealed a negative correlation between the net reduction in muscle fiber-type glycogen content and fiber-type oxidative capacity $(\mathrm{r}=-0.556$, 
$\mathrm{P}<0.05)$. As such, net changes in muscle fiber glycogen content were more pronounced in type IIx fibers compared to type I muscle fibers, which can be attributed to the greater recruitment of these fibers during high-intensity resistance exercise (13). During post-exercise recovery no significant differences in muscle glycogen content were observed over time in the type I, IIa or IIx muscle fibers. Furthermore, we observed a significant $27 \pm 7 \%$ reduction in type I muscle fiber lipid content $(\mathrm{P}<0.05)$. No changes in IMTG content were observed in the type IIa and IIx fibers (figure 3.5). The net reduction in IMTG content was significantly different compared to the type II fibers $(\mathrm{P}<0.05)$. On average, type I muscle fiber lipid content was $2.5 \pm 0.3$ and $8.8 \pm 1.4$ times greater when compared to the type IIa and IIx fibers, respectively. Due to the many methodological difficulties with the biochemical triacylglycerol extraction analyses on mixed muscle biopsy samples (21), we applied (immuno)histochemical IMTG analyses on oil red O stained muscle cross section to enable fiber-type specific determination of intramyocellular lipid content. The latter might be the reasons why Essen-Gustavsson and Tesch (9) failed to detect a significant reduction in mixed muscle lipid content following resistance exercise. In accordance, we observed a non-significant $25 \pm 10 \%$ net decline in calculated mixed muscle lipid content $(\mathrm{P}=0.087)$.

The reported net changes in muscle fiber-type specific lipid content following exercise were positively correlated with muscle fiber-type oxidative capacity (table 3.2). Interestingly, within $120 \mathrm{~min}$ of post-exercise recovery, muscle fiber lipid content had returned to pre-exercise values. This could be attributed to the substantial increase in circulating plasma FFA concentrations during post-exercise recovery. Which is similar to reports on IMTG accumulation under conditions of elevated plasma FFA availability, like prolonged fasting $(38,40)$, prolonged endurance exercise in regard to inactive muscle tissue (38) and/or $48 \mathrm{~h}$ of postexercise recovery on a relatively high-fat diet (46). The absence of a prolonged net reduction in skeletal muscle lipid content implies that the reported stimulating effects of resistance exercise on whole-body insulin sensitivity is unlikely to be attributed to a reduction in intramuscular lipid content. The latter is in line with the fact that the proposed relationship between IMTG deposition and insulin sensitivity does not appear functional (44). It has been suggested that the ratio between IMTG content and oxidative capacity likely represents a more appropriate parameter to assess the risk of developing insulin resistance and/or type 2 diabetes (43). This is especially important when evaluating the benefits of exercise intervention programs, as intervention studies have actually shown IMTG contents to remain stable or even increase despite substantial improvements in muscle oxidative capacity and/or whole-body insulin sensitivity $(3,17,36)$.

In conclusion, a single resistance exercise session substantially reduces intramyocellular lipid and glycogen content. These changes are fiber-type specific and are closely related to fiber-type oxidative capacity. The present data suggest that earlier reports on the acute improvements in whole-body insulin sensitivity following resistance exercise could, at least partly, be attributed to the net reduction in skeletal muscle glycogen content. 


\section{References}

1. Bergstrom J. Percutaneous needle biopsy of skeletal muscle in physiological and clinical research. Scand J Clin Lab Invest 35: 609-616, 1975.

2. Bogardus C, Thuillez P, Ravussin E, Vasquez B, Narimiga M, and Azhar S. Effect of muscle glycogen depletion on in vivo insulin action in man. J Clin Invest 72: 1605-1610, 1983.

3. Bruce CR, Kriketos AD, Cooney GJ, and Hawley JA. Disassociation of muscle triglyceride content and insulin sensitivity after exercise training in patients with Type 2 diabetes. Diabetologia 47: 23-30, 2004.

4. Chapman J, Garvin AW, Ward A, and Cartee GD. Unaltered insulin sensitivity after resistance exercise bout by postmenopausal women. Med Sci Sports Exerc 34: 936$941,2002$.

5. Craig BW, Everhart J, and Brown R. The influence of high-resistance training on glucose tolerance in young and elderly subjects. Mech Ageing Dev 49: 147-157, 1989.

6. Derave W, Hansen BF, Lund S, Kristiansen S, and Richter EA. Muscle glycogen content affects insulin-stimulated glucose transport and protein kinase B activity. Am J Physiol Endocrinol Metab 279: E947-955, 2000.

7. Devlin JT, Hirshman M, Horton ED, and Horton ES. Enhanced peripheral and splanchnic insulin sensitivity in NIDDM men after single bout of exercise. Diabetes 36: 434-439, 1987.

8. Devlin JT and Horton ES. Effects of prior high-intensity exercise on glucose metabolism in normal and insulin-resistant men. Diabetes 34: 973-979, 1985.

9. Essen-Gustavsson B and Tesch PA. Glycogen and triglyceride utilization in relation to muscle metabolic characteristics in men performing heavy-resistance exercise. Eur J Appl Physiol Occup Physiol 61: 5-10, 1990.

10. Evans WJ. Effects of exercise on body composition and functional capacity of the elderly. J Gerontol A Biol Sci Med Sci 50 Spec No: 147-150, 1995.

11. Fenicchia LM, Kanaley JA, Azevedo JL, Jr., Miller CS, Weinstock RS, Carhart RL, and Ploutz-Snyder LL. Influence of resistance exercise training on glucose control in women with type 2 diabetes. Metabolism 53: 284-289, 2004.

12. Fluckey JD, Hickey MS, Brambrink JK, Hart KK, Alexander K, and Craig BW. Effects of resistance exercise on glucose tolerance in normal and glucose-intolerant subjects. J Appl Physiol 77: 1087-1092, 1994.

13. Fry AC. The role of resistance exercise intensity on muscle fibre adaptations. Sports Med 34: 663-679, 2004.

14. Garcia-Roves PM, Han DH, Song Z, Jones TE, Hucker KA, and Holloszy JO. Prevention of glycogen supercompensation prolongs the increase in muscle GLUT4 after exercise. Am J Physiol Endocrinol Metab 285: E729-736, 2003.

15. Goodpaster BH, Kelley DE, Wing RR, Meier A, and Thaete FL. Effects of weight loss on regional fat distribution and insulin sensitivity in obesity. Diabetes 48: 839-847, 1999.

16. Gosker HR, van Mameren H, van Dijk PJ, Engelen MP, van der Vusse GJ, Wouters $\mathrm{EF}$, and Schols AM. Skeletal muscle fibre-type shifting and metabolic profile in patients with chronic obstructive pulmonary disease. Eur Respir J 19: 617-625, 2002.

17. He J, Goodpaster BH, and Kelley DE. Effects of weight loss and physical activity on muscle lipid content and droplet size. Obes Res 12: 761-769, 2004.

18. Hegarty BD, Furler SM, Ye J, Cooney GJ, and Kraegen EW. The role of intramuscular lipid in insulin resistance. Acta Physiol Scand 178: 373-383, 2003. 
19. Hoppeler H, Howald H, Conley K, Lindstedt SL, Claassen H, Vock P, and Weibel ER. Endurance training in humans: aerobic capacity and structure of skeletal muscle. J Appl Physiol 59: 320-327, 1985.

20. Houmard JA, Tanner CJ, Yu C, Cunningham PG, Pories WJ, MacDonald KG, and Shulman GI. Effect of weight loss on insulin sensitivity and intramuscular long-chain fatty acyl-CoAs in morbidly obese subjects. Diabetes 51: 2959-2963, 2002.

21. Howald H, Boesch C, Kreis R, Matter S, Billeter R, Essen-Gustavsson B, and Hoppeler H. Content of intramyocellular lipids derived by electron microscopy, biochemical assays, and (1)H-MR spectroscopy. J Appl Physiol 92: 2264-2272, 2002.

22. Kadi F and Thornell LE. Concomitant increases in myonuclear and satellite cell content in female trapezius muscle following strength training. Histochem Cell Biol 113: 99-103, 2000.

23. Keul J, Haralambie G, Bruder M, and Gottstein HJ. The effect of weight lifting exercise on heart rate and metabolism in experienced weight lifters. Med Sci Sports 10: 13-15, 1978.

24. Koopman R, Manders RJ, Zorenc AH, Hul GB, Kuipers H, Keizer HA, and van Loon LJ. A single session of resistance exercise enhances insulin sensitivity for at least $24 \mathrm{~h}$ in healthy men. Eur J Appl Physiol 94: 180-187, 2005.

25. Koopman R, Schaart G, and Hesselink MK. Optimisation of oil red O staining permits combination with immunofluorescence and automated quantification of lipids. Histochem Cell Biol 116: 63-68, 2001.

26. Kraemer WJ and Fry AC. Strength Testing; Development and Evaluation of Methodology. In: Physiological Assesment of Human Fitness, edited by Maud PJ and Foster C. Leeds: Human Kinetics, 1995, p. 115-133.

27. Mabuchi $\mathrm{K}$ and Sreter FA. Actomyosin ATPase. II. Fiber typing by histochemical ATPase reaction. Muscle Nerve 3: 233-239, 1980.

28. Macaluso A and De Vito G. Muscle strength, power and adaptations to resistance training in older people. Eur J Appl Physiol 91: 450-472, 2004.

29. Mayhew JL, Prinster JL, Ware JS, Zimmer DL, Arabas JR, and Bemben MG. Muscular endurance repetitions to predict bench press strength in men of different training levels. J Sports Med Phys Fitness 35: 108-113, 1995.

30. Mikines KJ, Sonne B, Farrell PA, Tronier B, and Galbo H. Effect of physical exercise on sensitivity and responsiveness to insulin in humans. Am J Physiol 254: E248-259, 1988.

31. Miller WJ, Sherman WM, and Ivy JL. Effect of strength training on glucose tolerance and post-glucose insulin response. Med Sci Sports Exerc 16: 539-543, 1984.

32. Nielsen JN and Richter EA. Regulation of glycogen synthase in skeletal muscle during exercise. Acta Physiol Scand 178: 309-319, 2003.

33. Oakes ND, Bell KS, Furler SM, Camilleri S, Saha AK, Ruderman NB, Chisholm DJ, and Kraegen EW. Diet-induced muscle insulin resistance in rats is ameliorated by acute dietary lipid withdrawal or a single bout of exercise: parallel relationship between insulin stimulation of glucose uptake and suppression of long-chain fatty acyl-CoA. Diabetes 46: 2022-2028, 1997.

34. Oakes ND, Camilleri S, Furler SM, Chisholm DJ, and Kraegen EW. The insulin sensitizer, BRL 49653, reduces systemic fatty acid supply and utilization and tissue lipid availability in the rat. Metabolism 46: 935-942, 1997.

35. Perseghin G, Price TB, Petersen KF, Roden M, Cline GW, Gerow K, Rothman DL, and Shulman GI. Increased glucose transport-phosphorylation and muscle glycogen synthesis after exercise training in insulin-resistant subjects. N Engl J Med 335: 1357 1362, 1996. 
36. Pruchnic R, Katsiaras A, He J, Kelley DE, Winters C, and Goodpaster BH. Exercise training increases intramyocellular lipid and oxidative capacity in older adults. Am J Physiol Endocrinol Metab 287: E857-862, 2004.

37. Schaart G, Hesselink RP, Keizer HA, Van Kranenburg G, Drost MR, and Hesselink MK. A modified PAS stain combined with immunofluorescence for quantitative analyses of glycogen in muscle sections. Histochem Cell Biol 122: 161-169, 2004.

38. Schrauwen-Hinderling VB, van Loon LJ, Koopman R, Nicolay K, Saris WH, and Kooi ME. Intramyocellular lipid content is increased after exercise in nonexercising human skeletal muscle. J Appl Physiol 95: 2328-2332, 2003.

39. Siri WE. The gross composition of the body. Adv Biol Med Physiol 4: 238-280, 1956.

40. Stannard SR, Thompson MW, Fairbairn K, Huard B, Sachinwalla T, and Thompson $\mathrm{CH}$. Fasting for $72 \mathrm{~h}$ increases intramyocellular lipid content in nondiabetic, physically fit men. Am J Physiol Endocrinol Metab 283: E1185-1191, 2002.

41. Tesch PA, Colliander EB, and Kaiser P. Muscle metabolism during intense, heavyresistance exercise. Eur J Appl Physiol Occup Physiol 55: 362-366, 1986.

42. Tsintzas K, Williams C, Constantin-Teodosiu D, Hultman E, Boobis L, and Greenhaff P. Carbohydrate ingestion prior to exercise augments the exercise-induced activation of the pyruvate dehydrogenase complex in human skeletal muscle. Exp Physiol 85: 581-586, 2000.

43. van Loon LJ and Goodpaster BH. Increased intramuscular lipid storage in the insulinresistant and endurance-trained state. Pflugers Arch 45: 606-16, 2006

44. van Loon LJ, Koopman R, Manders R, van der Weegen W, van Kranenburg GP, and Keizer HA. Intramyocellular lipid content in type 2 diabetes patients compared with overweight sedentary men and highly trained endurance athletes. Am J Physiol Endocrinol Metab 287: E558-565, 2004.

45. van Loon LJ, Koopman R, Stegen JH, Wagenmakers AJ, Keizer HA, and Saris WH. Intramyocellular lipids form an important substrate source during moderate intensity exercise in endurance-trained males in a fasted state. J Physiol 553: 611-625, 2003.

46. van Loon LJ, Schrauwen-Hinderling VB, Koopman R, Wagenmakers AJ, Hesselink MK, Schaart G, Kooi ME, and Saris WH. Influence of prolonged endurance cycling and recovery diet on intramuscular triglyceride content in trained males. Am J Physiol Endocrinol Metab 285: E804-811, 2003.

47. Watt MJ, Heigenhauser GJ, and Spriet LL. Intramuscular triacylglycerol utilization in human skeletal muscle during exercise: is there a controversy? J Appl Physiol 93: 1185$1195,2002$.

48. Wojtaszewski JF, Hansen BF, Gade, Kiens B, Markuns JF, Goodyear LJ, and Richter EA. Insulin signaling and insulin sensitivity after exercise in human skeletal muscle. Diabetes 49: 325-331, 2000.

49. Wojtaszewski JF, Hansen BF, Kiens B, and Richter EA. Insulin signaling in human skeletal muscle: time course and effect of exercise. Diabetes 46: 1775-1781, 1997.

50. Wojtaszewski JF, Jorgensen SB, Frosig C, MacDonald C, Birk JB, and Richter EA. Insulin signalling: effects of prior exercise. Acta Physiol Scand 178: 321-328, 2003. 



\section{4}

Changes in protein metabolism during and following prolonged endurance exercise: effect of nutritional supplements and discrepancies between tracers

René Koopman, Daphne L.E. Pannemans, Asker E. Jeukendrup, Annemie P. Gijsen, Joan M.G. Senden, David Halliday, Wim H.M. Saris, Luc J.C. van Loon and Anton J.M. Wagenmakers

Am J Physiol Endocrinol Metab (2004). 287:E558-65 


\begin{abstract}
The aims of this study were to compare different tracer methods to assess wholebody protein turnover during $6 \mathrm{~h}$ of prolonged endurance exercise when carbohydrate was ingested throughout and to investigate whether the addition of protein can improve protein balance. Eight endurance trained athletes were studied on 2 different occasions at rest (4h), during $6 \mathrm{~h}$ of exercise at $50 \% \mathrm{VO}_{2} \max$ (in sequential order: $2.5 \mathrm{~h}$ of cycling, $1 \mathrm{~h}$ running and $2.5 \mathrm{~h}$ of cycling) and during subsequent recovery (4h). Subjects ingested either carbohydrate (CHO trial; $0.7 \mathrm{~g}$ $\left.\mathrm{CHO} \cdot \mathrm{kg}^{-1} \cdot \mathrm{h}^{-1}\right)$ or carbohydrate/protein beverages $(\mathrm{CHO}+\mathrm{PRO}$ trial; $0.7 \mathrm{~g}$ $\mathrm{CHO} \cdot \mathrm{kg}^{-1} \cdot \mathrm{h}^{-1}$ and $0.25 \mathrm{~g} \mathrm{PRO} \cdot \mathrm{kg}^{-1} \cdot \mathrm{h}^{-1}$ ) at $30 \mathrm{~min}$ intervals during the entire study. Whole-body protein metabolism was determined by infusion of L-[1-13 C]leucine, L- $\left[{ }^{2} \mathrm{H}_{5}\right]$ phenylalanine and $\left[{ }^{15} \mathrm{~N}_{2}\right]$ urea tracers with sampling of blood and expired breath. Leucine oxidation increased from rest to exercise (CHO: $27 \pm 2.5$ vs.

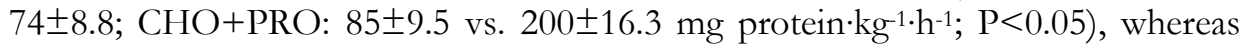
phenylalanine oxidation and urea production did not increase with exercise. Whole-body protein balance during exercise with carbohydrate ingestion was negative $\left(-74 \pm 8.8 ;-17 \pm 1.1 ;-72 \pm 5.7 \mathrm{mg}\right.$ protein $\cdot \mathrm{kg}^{-1} \cdot \mathrm{h}^{-1}$, when using L- $[1-$ $\left.{ }^{13} \mathrm{C}\right]$ leucine, L- $\left[{ }^{2} \mathrm{H}_{5}\right]$ phenylalanine and $\left[{ }^{15} \mathrm{~N}_{2}\right]$ urea as tracer). Addition of protein to the carbohydrate drinks resulted in a positive or less negative protein balance $\left(-32 \pm 16.3 ; 165 \pm 4.6 ; 151 \pm 13.4 \mathrm{mg}\right.$ protein $\cdot \mathrm{kg}^{-1} \cdot \mathrm{h}^{-1}$, when using L-[1-13C]leucine, L$\left[{ }^{2} \mathrm{H}_{5}\right]$ phenylalanine and $\left[{ }^{15} \mathrm{~N}_{2}\right]$ urea as tracer). We conclude that even during $6 \mathrm{~h}$ of exhaustive exercise in trained athletes using carbohydrate supplements; net protein oxidation does not increase, compared with the resting state and/or post-exercise recovery. Furthermore, the combined ingestion of both protein and carbohydrate improves net protein balance at rest as well as during exercise and post-exercise recovery.
\end{abstract}




\section{Introduction}

In the nineteenth century, skeletal muscle protein was thought to be the main fuel used to generate energy for muscle contractions (33). However, controlled nitrogen balance studies invalidated the proposed hypothesis as they showed no substantial increase in nitrogen loss during and/or following prolonged exercise (9, 14). Since then various methods have been applied to investigate the effects of exercise on protein metabolism. This has resulted in many discrepant findings in the literature, which are due in part to differences in the methodology employed and in part to the conditions under which different exercise interventions have been performed.

Since the introduction of stable isotope tracers in metabolic research, various methods have been applied to study whole-body protein metabolism. Most studies have used plasma L-[1-13C]leucine kinetics as a model for whole-body protein metabolism. Whereas several studies have reported increases in whole-body protein degradation during exercise $(23,25,39,40)$, others have failed to observe such changes $(6,26)$. Wolfe et al. (39) measured the rate of appearance of ${ }^{13} \mathrm{CO}_{2}$ in the expired breath from infused ${ }^{13} \mathrm{C}$-labeled leucine and reported a 3 -fold increase in leucine oxidation rates during exercise. The latter was shown to occur in the absence of a change in total leucine flux, which implies that the observed increase in protein breakdown was accompanied by a reduction in the rate of protein synthesis. Another tracer method that has been developed to determine wholebody protein metabolism, without the necessity of analyzing breath gasses, is the use of $\mathrm{L}-\left[{ }^{2} \mathrm{H}_{5}\right]$ phenylalanine according to the model of Clarke and Bier (10) and Thompson et al (27). However, that method has not yet been applied to investigate the effect of prolonged endurance exercise. Studies applying $\left[{ }^{15} \mathrm{~N}\right]$ urea to determine the rate of urea production as a measure of the amount of amino acids that are liberated by net protein degradation (degradation - synthesis) and oxidized (with conversion of the amino group to urea) during exercise, have not confirmed the catabolic nature of prolonged endurance exercise $(7,39)$.

The reports using urea as a tracer, indicate that protein synthesis and degradation rates do not change during endurance type activities. However, nitrogen balance data from field studies suggest that prolonged endurance exercise, leading to glycogen depletion, is accompanied by a substantial increase in net protein breakdown (13). In accordance, activation of the branched-chain $\alpha$-keto acid dehydrogenase complex, the enzyme responsible for leucine oxidation in the muscle, has been shown to increase during exercise when glycogen stores are low $(34,35)$. During competition many endurance athletes (e.g. cyclists, triathletes and ultra-marathon runners) exercise for more than $5 \mathrm{~h}$ at relatively high workloads and deplete their glycogen stores to a large extent. However, whole-body protein turnover measurements using multiple amino acid tracers have not yet been performed during such prolonged exhaustive exercise activity.

Endurance trained athletes try to optimize carbohydrate availability through carbohydrate ingestion before, during and after exercise. However, most studies 
measuring protein turnover during exercise have been performed following an overnight fast and with nutritional interventions generally applied during the postexercise recovery phase. Little information is available about the effects of carbohydrate or carbohydrate and protein supplementation on protein metabolism during exercise. The available literature indicates that combined ingestion of carbohydrate and protein in the post-exercise recovery phase improves net protein balance $(12,22)$, at least after resistance exercise $(2,3,24,28,29)$. Ingestion of such a substrate mixture during exercise could possibly also affect protein balance during and after prolonged endurance exercise.

In the present study, we determined whole-body protein synthesis and degradation rates at rest, during prolonged exhaustive exercise and during subsequent recovery. A multiple tracer approach, applying L-[1-13 C]leucine, L- $\left[{ }^{2} \mathrm{H}_{5}\right]$ phenylalanine and $\left[{ }^{15} \mathrm{~N}_{2}\right]$ urea infusions was chosen to investigate whether there are differences in outcome depending on the applied tracer model. These studies were performed in a laboratory setting that resembles real-life endurance exercise competition in elite triathletes, combining $6 \mathrm{~h}$ of exercise with regular carbohydrate supplementation. In addition, we investigated whether the addition of protein to carbohydrate ingestion can improve net protein balance during exercise and subsequent recovery compared with the ingestion of only carbohydrate.

\section{Methods}

\section{Subjects}

Eight well-trained male subjects (age: $31 \pm 3 \mathrm{y}$; height: $1.84 \pm 0.03 \mathrm{~m}$; weight: $72.4 \pm 2.3 \mathrm{~kg}$; body mass index (BMI): $21.4 \pm 0.3 \mathrm{~kg} \cdot \mathrm{m}^{-2} ; \%$ bodyfat: $9.6 \pm 0.8 \%$, fat free mass: $65.7 \pm 1.3 \mathrm{~kg}$; maximal workload capacity (Wmax): $383 \pm 13 \mathrm{~W}$; maximal oxygen uptake capacity $\left.\left(\mathrm{VO}_{2} \mathrm{max}\right): 4.9 \pm 0.2 \mathrm{~L} \cdot \mathrm{min}^{-1}\right)$ participated in this study. Subjects trained around $15 \mathrm{~h}$ a week ( $3 \mathrm{~h}$ swimming, $7 \mathrm{~h}$ cycling and $5 \mathrm{~h}$ running) and had a training history $>5 y$. Subjects were informed about the nature and risks of the procedures before their written informed consent was obtained. This study was approved by the local medical ethical committee of the Academic Hospital Maastricht.

\section{Pre-testing}

$\mathrm{VO}_{2} \mathrm{max}$ and $\mathrm{Wmax}$ were measured on an electronically braked cycle ergometer (Lode Excalibur, Groningen, The Netherlands) during an incremental exhaustive exercise test (17) one week before the first trial to determine the $45 \% \mathrm{Wmax}$ workload $\left(179 \pm 8.6 \mathrm{~W} ; \sim 50 \% \mathrm{VO}_{2} \mathrm{max}\right)$, which was applied in these studies. Maximum running velocity was determined on a motor driven treadmill with a $1 \%$ incline (to represent outdoor running) using an incremental exhaustive exercise test to determine the $45 \%$ maximal running velocity $(V \max )\left(11.0 \pm 0.3 \mathrm{~km} \cdot \mathrm{h}^{-1} ; \sim 50 \%\right.$ $\left.\mathrm{VO}_{2} \max \right)$. After a 5 min warm-up at $10 \mathrm{~km} \cdot \mathrm{h}^{-1}$, speed was increased every 3 
minutes by $2 \mathrm{~km} \cdot \mathrm{h}^{-1}$, and from a heart rate of $85 \%$ of maximal heart rate with 1 $\mathrm{km} \cdot \mathrm{h}^{-1}$ every 3 minutes until the subject was unable to continue.

\section{Diet and activity prior to testing}

All subjects were instructed not to consume any products with a high natural abundance of ${ }^{13} \mathrm{C}$ (carbohydrates derived from $\mathrm{C} 4$ plants: corn, sugar cane) one week before the first trial and during the entire test period. This has been shown to minimize possible shifts in background enrichment due to changes in endogenous substrate utilization (36). All subjects were also instructed to refrain from heavy physical exercise and to maintain normal dietary habits for 3 days prior to each trial. In addition, we asked subjects to record their food intake for $48 \mathrm{~h}$ before the start of the first experimental trial and to consume exactly the same food $48 \mathrm{~h}$ before the start of the second test.

\section{Studies}

All subjects were studied on two different occasions. Each test day consisted of three parts during which whole-body protein turnover and whole-body urea production rate, were measured at rest, during prolonged exercise and subsequent recovery. Via a randomized cross-over design, subjects received beverages containing either carbohydrate $(\mathrm{CHO})$ or carbohydrate with protein hydrolysate $(\mathrm{CHO}+\mathrm{PRO})$ during each trial. An outline of the study design is presented in figure 4.1 .

$\left[1-{ }^{13} \mathrm{C}\right]$ leucine, $\left[{ }^{2} \mathrm{H}_{5}\right]$ phenylalanine and $\left[{ }^{15} \mathrm{~N}_{2}\right]$ urea infusion
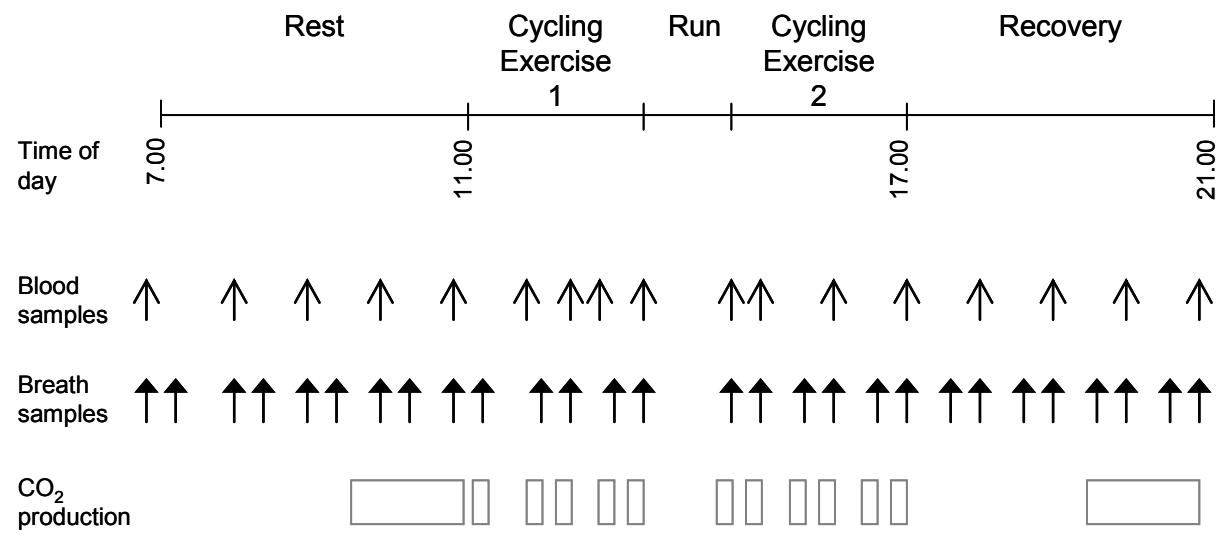

Figure 4.1 Schematic outline of the study protocol. Cycling and running exercises were performed at $50 \%$ $\mathrm{VO}_{2} \mathrm{max}$. Every $30 \mathrm{~min}$ throughout the entire test, subjects received a beverage volume of $4 \mathrm{ml} \cdot \mathrm{kg}^{-1}$ to ensure a given dose of $0.7 \mathrm{~g} \mathrm{~kg}^{-1} \cdot \mathrm{h}^{-1}$ carbohydrates (maltodextrin) in the control trial (CHO) and $0.7 \mathrm{~g}^{\circ} \mathrm{kg}^{-1} \cdot \mathrm{h}^{-1}$ carbohydrate and $0.25 \mathrm{~g} \cdot \mathrm{kg}^{-1} \cdot \mathrm{h}^{-1}$ protein hydrolysate in the $\mathrm{CHO}+\mathrm{PRO}$ trial. 


\section{Protocol}

The subjects reported at the laboratory at $7.00 \mathrm{am}$ after an overnight fast. A Teflon catheter (Baxter BV, Utrecht, The Netherlands) was inserted into an antecubital vein of one arm for blood sampling; another catheter was inserted in the contralateral arm for isotope infusion. A resting blood sample was drawn and expired breath samples were collected into vacutainer tubes (Becton Dickinson, Meylan, France) to measure baseline enrichments. Thereafter, a single intravenous dose of $\mathrm{NaH}^{13} \mathrm{CO}_{3}\left(5.9 \mu \mathrm{mol} \cdot \mathrm{kg}^{-1}\right)$ was administered to prime the bicarbonate pool, which was followed by a L-[1-13 C]leucine $\left(7.6 \mu \mathrm{mol} \cdot \mathrm{kg}^{-1}\right), \mathrm{L}_{-}\left[{ }^{2} \mathrm{H}_{5}\right]$ phenylalanine $(3.0$ $\left.\mu \mathrm{mol} \cdot \mathrm{kg}^{-1}\right),\left[{ }^{15} \mathrm{~N}_{2}\right]$ urea $\left(88 \mu \mathrm{mol} \cdot \mathrm{kg}^{-1}\right)$ and $\mathrm{L}-\left[{ }^{2} \mathrm{H}_{4}\right]$ tyrosine $\left(0.46 \mu \mathrm{mol} \cdot \mathrm{kg}^{-1}\right)$ prime. Thereafter $(\mathrm{t}=0)$, continuous infusion of $\mathrm{L}-\left[1-{ }^{13} \mathrm{C}\right]$ leucine $\left(7.6 \mu \mathrm{mol} \cdot \mathrm{kg}^{-1} \cdot \mathrm{h}^{-1}\right)$, L$\left[{ }^{2} \mathrm{H}_{5}\right]$ phenylalanine $\left(3 \mu \mathrm{mol} \cdot \mathrm{kg}^{-1} \cdot \mathrm{h}^{-1}\right),\left[{ }^{15} \mathrm{~N}_{2}\right]$ urea $\left(88 \mu \mathrm{mol} \cdot \mathrm{kg}^{-1} \cdot \mathrm{h}^{-1}\right)$ was started via a calibrated IVAC 560 pump (San Diego, CA, USA) and continued for 14h. After the start of the tracer infusion, subjects rested for $4 \mathrm{~h}$ (resting period). Subsequently, subjects exercised for $6 \mathrm{~h}$ at a moderate intensity (45\% Wmax), starting with $2.5 \mathrm{~h}$ of cycling, followed by $1 \mathrm{~h}$ of treadmill running, and another $2.5 \mathrm{~h}$ of cycling exercise. Subjects were not allowed to rest between the different exercise bouts apart from the time necessary to change from ergometer to treadmill and back. After cessation of exercise, subjects rested for $4 \mathrm{~h}$ (recovery). During the preexercise resting period and during the post-exercise recovery phase breath and blood samples were obtained every 30 and 60 minutes, respectively. During cycling exercise periods blood and breath samples were collected every 30 minutes and $\mathrm{VO}_{2}$ and $\mathrm{VCO}_{2}$ were measured (Oxycon- $\beta$, Mijnhardt, Bunnik, The Netherlands) at $30 \mathrm{~min}$ intervals for $5 \mathrm{~min}$.

\section{Beverages}

Directly after the start of the stable isotope infusion and every $30 \mathrm{~min}$ throughout the entire trial (before, during and after exercise), subjects received a beverage volume of $4 \mathrm{ml} \cdot \mathrm{kg}^{-1}$ to ensure a given dose of $0.7 \mathrm{~g} \cdot \mathrm{kg}^{-1} \cdot \mathrm{h}^{-1}$ carbohydrates (maltodextrin) in the control trial (CHO) and $0.7 \mathrm{~g} \cdot \mathrm{kg}^{-1} \cdot \mathrm{h}^{-1}$ carbohydrate and 0.25 $\mathrm{g} \cdot \mathrm{kg}^{-1} \cdot \mathrm{h}^{-1}$ protein hydrolysate in the $\mathrm{CHO}+\mathrm{PRO}$ trial. The drinks were prepared by Quest International (Naarden, The Netherlands). L- $\left[{ }^{2} \mathrm{H}_{5}\right]$ phenylalanine and L-[1$\left.{ }^{13} \mathrm{C}\right]$ leucine enrichment in the beverages was measured using GC-MS and did not differ from the $\mathrm{L}-\left[{ }^{2} \mathrm{H}_{5}\right]$ phenylalanine and $\mathrm{L}-\left[1-{ }^{13} \mathrm{C}\right]$ leucine enrichment in the plasma background samples. Therefore, beverage ingestion did not alter plasma enrichment and corrections were not required. The beverages contained per liter: $80 \mathrm{~g}$ maltodextrin, $25 \mathrm{~g}$ glucose syrup, $0.3 \mathrm{~g}$ sodium-benzoaat, $2.25 \mathrm{~g}$ citrus compound, $1 \mathrm{~g}$ citric acid and $0.2 \mathrm{~g}$ ascorbic acid with or without the addition of 30 g rice hydrolysate (Hyprol Dev 8115, Quest International). Amino acid profile of the rice hydrolysate is listed in table 4.1. 
Table 4.1 Amino acid composition of the protein hydrolysate

\begin{tabular}{lc}
\hline Amino acids & Rice hydrolysate \\
\hline L-Arginine (Arg) & 5.6 \\
L-Histidine (His) & 1.5 \\
L-Asparagnine (Asn) & 4.1 \\
L-Glutamine (Gln) & 7.7 \\
L-Lysine (Lys) & 2.8 \\
L-Glycine (Gly) & 2.7 \\
L-Alanine (Ala) & 3.5 \\
L-Tryptophan (Trp) & 0.6 \\
L-Serine (Ser) & 3.4 \\
L-Proline (Pro) & 2.4 \\
L-Valine (Val) & 3.9 \\
L-Threonine (Thr) & 2.4 \\
L-Cysteine (Cys) & 0.6 \\
L-Isoleucine (Ile) & 2.8 \\
L-Leucine (Leu) & 5.2 \\
L-Aspartate (Asp) & 2.4 \\
L-Glutamate (Glu) & 4.5 \\
L-Methionine (Met) & 1.4 \\
L-Phenylalanine (Phe) & 3.6 \\
L-Tyrosine (Tyr) & 3.3 \\
\hline
\end{tabular}

Values expressed in $\mathrm{g} \cdot 100 \mathrm{~g}$ dry product ${ }^{-1}$.

\section{Plasma analyses}

Blood samples were collected in EDTA containing tubes and centrifuged at $1000 \mathrm{~g}$ and $4^{\circ} \mathrm{C}$ for $5 \mathrm{~min}$. Aliquots of plasma were frozen in liquid nitrogen and stored at $-80^{\circ} \mathrm{C}$. Plasma $\left[1-{ }^{13} \mathrm{C}\right]$ alpha-Ketoisocaproate (KIC) enrichment was measured using a quinoxalinoltrimethylsilyl derivate (31), whereas $\mathrm{L}_{-}\left[{ }^{2} \mathrm{H}_{5}\right]$ phenylalanine and $\mathrm{L}-\left[{ }^{2} \mathrm{H}_{4}\right]$ tyrosine enrichments were measured using their t-butyldimethylsilyl derivates on a gas chromatography mass spectrometer (GC-MS) (Finnigan: Incos XL, Bremen, Germany) (27). Plasma $\left[{ }^{15} \mathrm{~N}_{2}\right]$ urea enrichment was measured using the N,N'-bistrimethylsilyl derivate of urea on a GC-MS (39). Breath ${ }^{13} \mathrm{CO}_{2}$ enrichment in the expired air was measured by GC continuous flow-IRMS (Finnigan, MAT-252).

\section{Calculations}

The rate of protein turnover was calculated as described previously (20). Briefly, leucine turnover (flux, Q) was measured from the dilution of L-[1-13C]leucine infusion in plasma alpha-KIC at isotopic steady state:

$$
Q=i \cdot\left(\frac{E i}{E p}-1\right)
$$

where $\mathrm{i}$ is the $\left[1{ }^{13} \mathrm{C}\right]$ leucine infusion rate $\left(\mu \mathrm{mol} \cdot \mathrm{kg}\right.$ body weight $\left.{ }^{-1} \cdot \mathrm{h}^{-1}\right), \mathrm{Ei}$ is the enrichment of the $\left[1-{ }^{13} \mathrm{C}\right]$ Leucine infused (expressed in atom percent excess; APE) 
and Ep is the $\left[1-{ }^{13} \mathrm{C}\right]$ alpha-KIC enrichment in the plasma at steady state (APE). The background enrichment of expired ${ }^{13} \mathrm{CO}_{2}$ was measured before the start of tracer infusions. This background enrichment was subtracted from the isotopic plateau value for the calculation of leucine oxidation. Leucine oxidation rates were also corrected for bicarbonate retention. In endurance trained subjects, employed bicarbonate retention factors were $83.1 \%$ for rest and $98.9 \%$ for exercise (11). The rate of leucine oxidation is calculated using,

$$
O={ }^{13} \mathrm{CO}_{2} \cdot\left(\frac{1}{L(E p}\right)-\left(\frac{1}{E i}\right)_{-}^{\top} 100
$$

where $\mathrm{F}^{13} \mathrm{CO}_{2}$ is the rate of ${ }^{13} \mathrm{CO}_{2}$ production and release in the expired breath $\left(\mu \mathrm{mol}{ }^{13} \mathrm{CO}_{2} \cdot \mathrm{kg}^{-1} \cdot \mathrm{h}^{-1}\right)$. At isotopic steady state, protein flux (Q) equals the sum of protein synthesis $(\mathrm{S})$ and oxidation $(\mathrm{O})$ as well as the sum of the rate of appearance of meal protein from the gut (I) and protein breakdown (B), whole-body protein synthesis rate was calculated as flux minus oxidation.

$$
\begin{aligned}
& Q=5+\jmath=3+ \\
& S=?-\text { ) }
\end{aligned}
$$

The leucine parameters mentioned above were converted to corresponding estimates of whole-body protein turnover by multiplying the leucine values by the constant $1 /\left(590 \mu \mathrm{mol}\right.$ leucine $\cdot \mathrm{g}^{-1}$ protein $)$ to give values of $\mathrm{g}$ protein $\cdot \mathrm{kg}^{-1} \cdot \mathrm{h}^{-1}(20)$. The $590 \mu$ mol leucine $g$ protein ${ }^{-1}$ factor corresponds to a protein leucine content of $7.8 \%$ and was derived from averaged values for leucine content of protein of human and other mammal muscles (20).

In addition, we used the phenylalanine balance model as described by Thompson et al (27). In this model, phenylalanine flux (Qp) can be calculated by isotope dilution using equation 1 , where $\mathrm{i}$ is the $\mathrm{L}-\left[{ }^{2} \mathrm{H}_{5}\right]$ phenylalanine infusion rate $\left(\mu \mathrm{mol} \cdot \mathrm{kg}^{-1} \cdot \mathrm{h}^{-1}\right), \mathrm{Ei}$ is the enrichment of the L- $\left[{ }^{2} \mathrm{H}_{5}\right]$ phenylalanine infused (expressed in APE) and Ep is the $\mathrm{L}_{-}\left[{ }^{2} \mathrm{H}_{5}\right]$ phenylalanine in the plasma at steady state (APE). At isotopic steady state, whole-body phenylalanine oxidation can be determined from the conversion (hydroxylation) of $\mathrm{L}-\left[{ }^{2} \mathrm{H}_{5}\right]$ phenylalanine to $\mathrm{L}-\left[{ }^{2} \mathrm{H}_{4}\right]$ tyrosine. The rate of hydroxylation (Qpt) was calculated (27) using the formula

$$
Q_{p t}=\frac{-}{P_{p}} \cdot\left(\frac{P_{t} \cdot Q_{p}{ }^{2}}{\frac{E_{p}}{E_{t}}-1}\right) \frac{2_{p}-}{p_{-}}
$$

where $\mathrm{P}_{\mathrm{t}} / \mathrm{P}_{\mathrm{p}}(=0.73)$ is the molar ratio of the fluxes of tyrosine and phenylalanine arising from protein catabolism (27), Qp is the phenylalanine flux, Et is the L$\left[{ }^{2} \mathrm{H}_{4}\right]$ tyrosine enrichment, and ip is the $\mathrm{L}-\left[{ }^{2} \mathrm{H}_{5}\right]$ phenylalanine infusion rate $(\mu \mathrm{mol} \cdot \mathrm{kg}$ $\left.{ }^{1} \cdot \mathrm{h}^{-1}\right)$. Protein synthesis and degradation using this approach was calculated using

$$
Q=i+2 p t=3+
$$

Rates of protein synthesis and degradation (g protein $\mathrm{kg}$ bodyweight $\mathrm{t}^{-1} \cdot \mathrm{h}^{-1}$ ) are calculated using the phenylalanine content of protein of $280 \mu \mathrm{mol} \cdot \mathrm{g}^{-1}$ protein (27). 
The $280 \mu \mathrm{mol}$ phenylalanine.g protein ${ }^{-1}$ factor was derived from protein composition measurements in animals (21).

The net protein balance (table 4.2) was calculated from the difference between whole-body protein synthesis (S) and degradation (B) determined using the leucine and phenylalanine model as described above.

The rate of urea production was calculated using equations described previously (38). In short, at isotopic steady state during the constant infusion of $\left[{ }^{15} \mathrm{~N}_{2}\right]$ urea, two enrichments (expressed in tracer tracee ratio; TTR) were measured, A and B

$$
A=\frac{\text { ingly labeled urea }}{\text { unlabeled urea }} \quad B=\frac{\text { toubly labeled urea }}{\text { unlabeledurea }}
$$

The rate of urea production was calculated using

$$
Q=\frac{2 F}{A}+\bar{B}
$$

where $\mathrm{F}$ is the $\left[{ }^{15} \mathrm{~N}_{2}\right]$ urea infusion rate $\left(\mu \mathrm{mol} \cdot \mathrm{kg}^{-1} \cdot \mathrm{h}^{-1}\right)$.

The net balance of the amount $\left(\mathrm{g}^{\mathrm{kg}} \mathrm{kg}^{-1} \cdot \mathrm{h}^{-1}\right)$ of protein that was broken down in the $\mathrm{CHO}$ trial and converted to urea was calculated by converting urea production rates to $\mathrm{mg} \mathrm{N}$ produced per $\mathrm{kg}$ per $\mathrm{h}$ and multiplying with $6.25(1 \mathrm{~g}$ of protein contains $160 \mathrm{mg}$ of nitrogen). The positive protein net balance (protein synthesis protein degradation) reported in table 4.2 was calculated in this case by again converting the observed urea production rate to protein oxidation rates and then taking the difference between protein ingestion and protein oxidation (both in $g$ protein $\left.\cdot \mathrm{kg}^{-1} \cdot \mathrm{h}^{-1}\right)$.

\section{Statistics}

All data are expressed as mean \pm SEM. To compare tracer kinetics, protein synthesis and degradation rates between the different interventions over time, a two way repeated measures ANOVA was used with both subject and treatment as factors. A Scheffé's post-hoc test was applied in case of a significant F-ratio to locate specific differences. Student's t-tests for paired observations were used to compare differences in protein synthesis, breakdown, oxidation, net balance and urea production between the $\mathrm{CHO}$ and $\mathrm{CHO}+\mathrm{PRO}$ trial. Significance was set at the 0.05 level of confidence. 


\section{Results}

\section{Tracer kinetics}
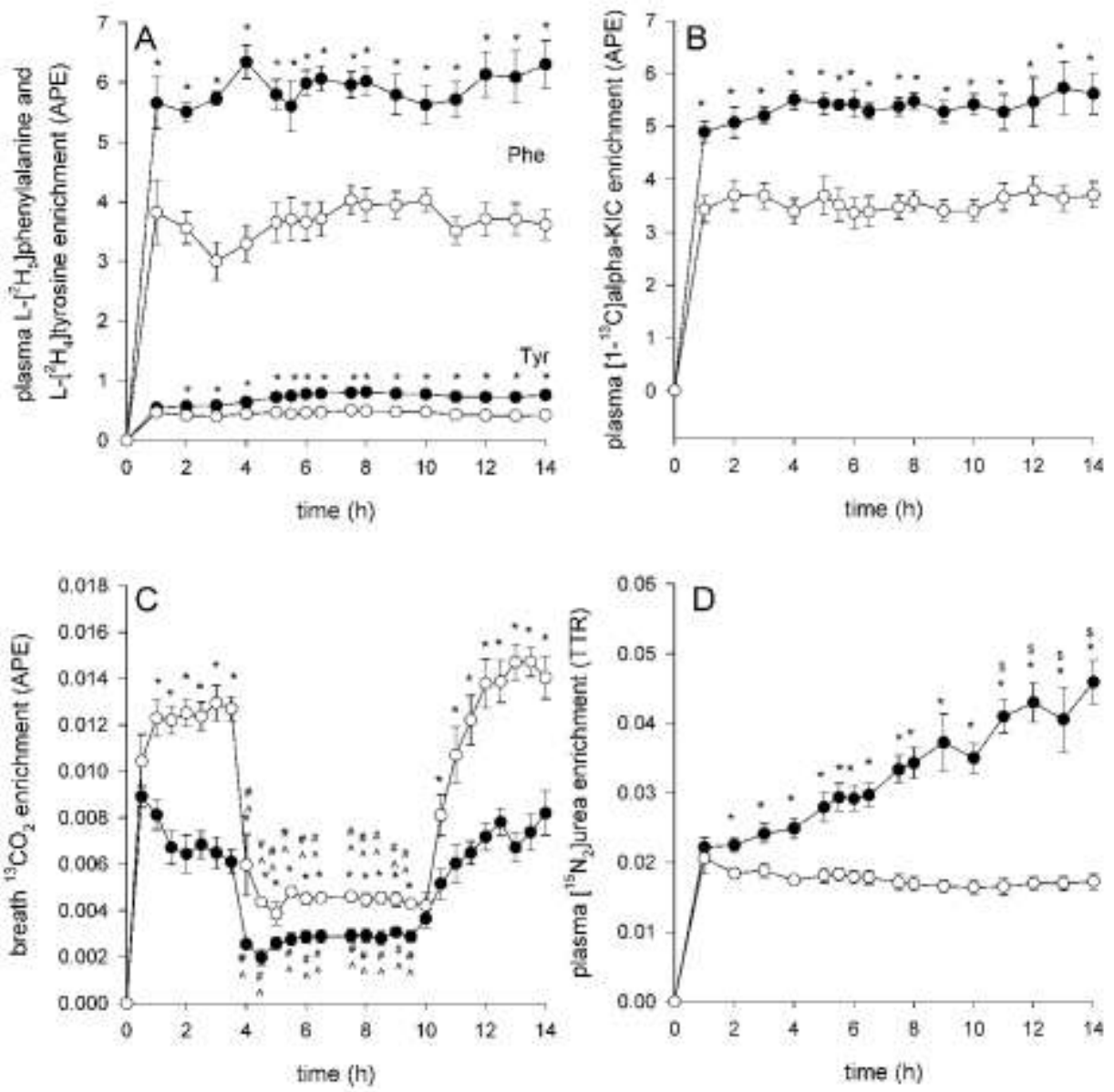

Figure 4.2 Tracer data. A, plasma L- $\left[{ }^{2} \mathrm{H}_{5}\right]$ phenylalanine (Phe) and L- $\left[{ }^{2} \mathrm{H}_{4}\right]$ tyrosine (Tyr) enrichment; B, plasma $\left[{ }^{13} \mathrm{C}\right]$ alphaKIC; C, breath ${ }^{13} \mathrm{CO}_{2}$ enrichment; D, plasma $\left[{ }^{15} \mathrm{~N}_{2}\right]$ urea enrichment. APE, atom percent excess. Data are means \pm SEM. * Significantly different between studies $(\mathrm{P}<0.05) ; \wedge$ significantly different from rest $(\mathrm{P}<0.05)$; \# significantly different from recovery $(\mathrm{P}<0.05)$

Plasma L- $\left[{ }^{2} \mathrm{H}_{5}\right]$ phenylalanine and L- $\left[{ }^{2} \mathrm{H}_{4}\right]$ tyrosine enrichment, plasma $\left[1-{ }^{13} \mathrm{C}\right]$ alphaKIC enrichment, breath ${ }^{13} \mathrm{CO}_{2}$ enrichment and plasma $\left[{ }^{15} \mathrm{~N}_{2}\right]$ urea enrichment are shown in figure $4.2 \mathrm{~A}, \mathrm{~B}, \mathrm{C}$ and $\mathrm{D}$, respectively. Plasma L- $\left[{ }^{2} \mathrm{H}_{5}\right]$ phenylalanine, L$\left[{ }^{2} \mathrm{H}_{4}\right]$ tyrosine, $\left[1-{ }^{13} \mathrm{C}\right]$ alpha-KIC reached a steady state after $2 \mathrm{~h}$ of infusion. Breath ${ }^{13} \mathrm{CO}_{2}$ enrichment was significantly lower during exercise $(\mathrm{P}<0.05)$ compared with 
both resting conditions and post-exercise recovery. Plasma $\left[{ }^{15} \mathrm{~N}_{2}\right]$ urea enrichment slightly increased over time during the $\mathrm{CHO}$ trial, with significantly higher plasma $\left[{ }^{15} \mathrm{~N}_{2}\right]$ urea enrichment during recovery compared with pre-exercise resting values $(\mathrm{P}<0.05)$. In contrast, during the $\mathrm{CHO}+\mathrm{PRO}$ trial plasma $\left[{ }^{15} \mathrm{~N}_{2}\right]$ urea enrichment remained constant throughout the entire trial. During the $\mathrm{CHO}+\mathrm{PRO}$ trial plasma L- $\left[{ }^{2} \mathrm{H}_{5}\right]$ phenylalanine, L- $\left[{ }^{2} \mathrm{H}_{4}\right]$ tyrosine, $\left[{ }^{1}-{ }^{13} \mathrm{C}\right] \mathrm{alpha}-\mathrm{KIC}$ and $\left[{ }^{15} \mathrm{~N}_{2}\right]$ urea enrichments were significantly lowered compared with the $\mathrm{CHO}$ trial $(\mathrm{P}<0.05)$. Breath ${ }^{13} \mathrm{CO}_{2}$ enrichment was elevated during the $\mathrm{CHO}+\mathrm{PRO}$ trial compared with the CHO trial $(\mathrm{P}<0.05)$.

\section{Phenylalanine model}

Protein flux was similar at rest, during exercise 1 and 2 and during post-exercise recovery $\left(176 \pm 6,170 \pm 6,172 \pm 7\right.$ and $162 \pm 15 \mathrm{mg}$ protein $\cdot \mathrm{kg}^{-1} \cdot \mathrm{h}^{-1}$ respectively) in the $\mathrm{CHO}$ trial and $\left(303 \pm 26,294 \pm 14,264 \pm 14\right.$ and $293 \pm 21 \mathrm{mg}$ protein $\cdot \mathrm{kg}^{-1} \cdot \mathrm{h}^{-1}$ respectively) in the $\mathrm{CHO}+\mathrm{PRO}$ trial. However, in the $\mathrm{CHO}+\mathrm{PRO}$ trial, protein flux was $\sim 70 \%$ increased at rest, during exercise and in the post-exercise recovery phase, when compared with the $\mathrm{CHO}$ trial $(\mathrm{P}<0.01)$.
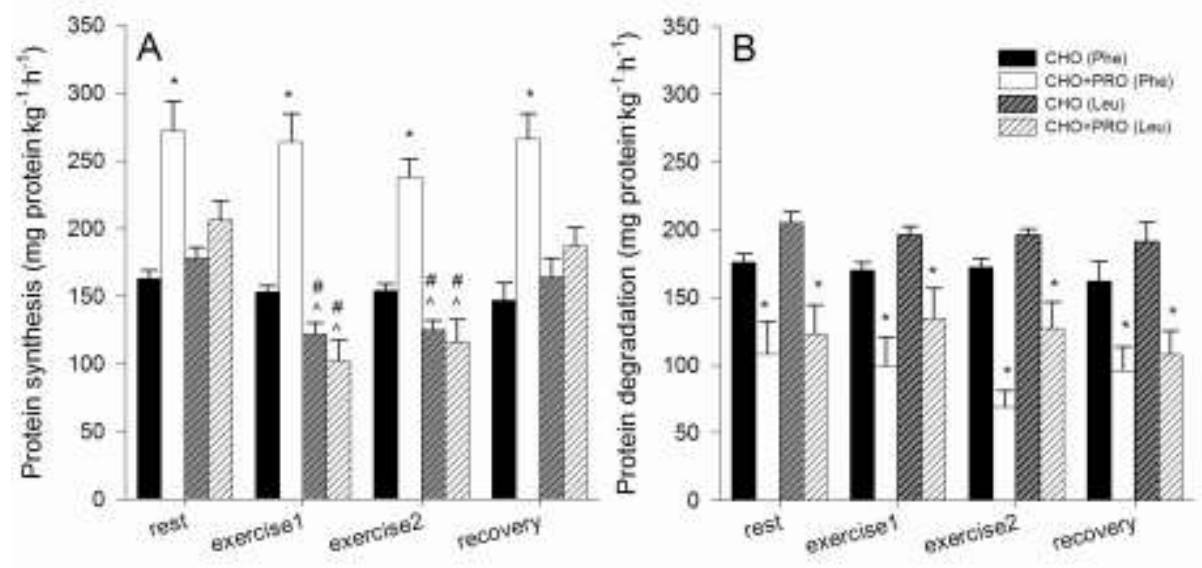

Figure 4.3 Whole-body protein synthesis (A) and degradation (B) calculated on basis L-[ $\left.1-{ }^{13} \mathrm{C}\right]$ leucine and $\mathrm{L}-\left[{ }^{2} \mathrm{H}_{5}\right]$ phenylalanine at rest, during exercise 1 and 2 and during recovery. Data are means \pm SEM; ${ }^{\wedge}$ significantly different from rest $(\mathrm{P}<0.01)$; \# significantly different from recovery $(\mathrm{P}<0.01)$; ${ }^{*}$ significantly different between studies $(\mathrm{P}<0.05)$.

Whole-body protein synthesis ( $\mathrm{mg}$ protein $\mathrm{kg}^{-1} \mathrm{~h}^{-1}$ ) during the $\mathrm{CHO}$ and $\mathrm{CHO}+\mathrm{PRO}$ trials is shown in figure 4.3A. No differences were found in protein synthesis rates during exercise compared to rest and recovery phase. However, under all conditions protein synthesis rates were higher in the $\mathrm{CHO}+\mathrm{PRO}$ trial, when compared with the $\mathrm{CHO}$ trial $(\mathrm{P}<0.01)$. 
Chapter 4 
Protein degradation rates ( $\mathrm{mg}$ protein $\cdot \mathrm{kg}^{-1} \cdot \mathrm{h}^{-1}$ ) did not change during exercise (figure 4.3B). A marked decrease in protein breakdown was observed throughout the $\mathrm{CHO}+\mathrm{PRO}$ trial, when compared with the $\mathrm{CHO}$ trial $(\mathrm{P}<0.01)$.

Whole-body protein oxidation $\left(\mathrm{mg}\right.$ protein $\left.\cdot \mathrm{kg}^{-1} \cdot \mathrm{h}^{-1}\right)$ is shown in figure 4.4 . Wholebody protein oxidation was similar at rest, during exercise and during post-exercise recovery $\left(13 \pm 1,17 \pm 1,19 \pm 2\right.$ and $15 \pm 2 \mathrm{mg}$ protein $\cdot \mathrm{kg}^{-1} \cdot \mathrm{h}^{-1}$ respectively) in the $\mathrm{CHO}$ trial and $\left(31 \pm 4,30 \pm 3,25 \pm 2\right.$ and $27 \pm 3 \mathrm{mg}$ protein $\cdot \mathrm{kg}^{-1} \cdot \mathrm{h}^{-1}$ respectively) in the $\mathrm{CHO}+\mathrm{PRO}$ trial. During the $\mathrm{CHO}+\mathrm{PRO}$ trial protein oxidation rates were higher at rest, during exercise and recovery when compared with the $\mathrm{CHO}$ trial $(\mathrm{P}<0.05)$. During exercise, whole-body protein balance $\left(\mathrm{mg}\right.$ protein $\cdot \mathrm{kg}^{-1} \cdot \mathrm{h}^{-1}$ ) was not different from resting conditions and post-exercise recovery (figure 4.5). In the $\mathrm{CHO}+\mathrm{PRO}$ trial, protein balance was positive whereas protein balance was negative in the CHO trial.

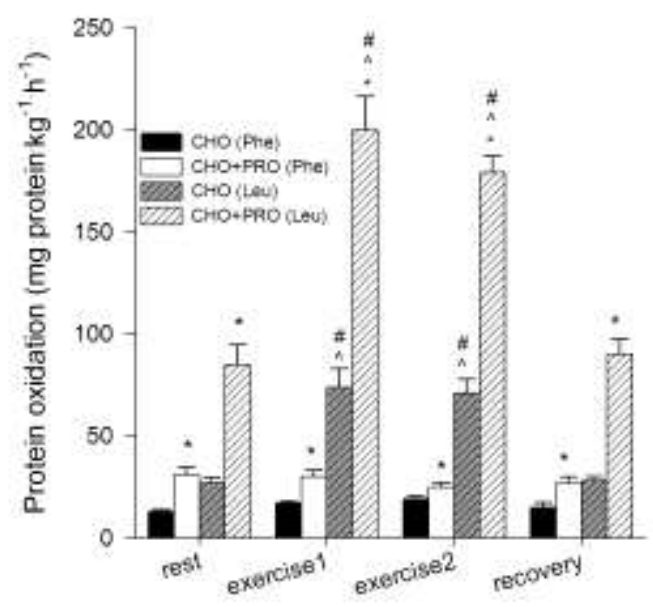

Figure 4.4 Whole-body protein oxidation calculated on basis $\mathrm{L}-\left[1-{ }^{13} \mathrm{C}\right]$ leucine and $\mathrm{L}-\left[{ }^{2} \mathrm{H}_{5}\right]$ phenylalanine at rest, during exercise 1 and 2 and during recovery. Data are means $\pm \mathrm{SEM} ;{ }^{\wedge}$ significantly different from rest $(\mathrm{P}<0.01)$; \# significantly different from recovery $(\mathrm{P}<0.01) ; *$ significantly different between studies $(\mathrm{P}<0.05)$.

\section{Leucine model}

Protein flux (mg protein $\cdot \mathrm{kg}^{-1} \cdot \mathrm{h}^{-1}$ ) was not different during exercise compared with fluxes at rest and during post-exercise recovery. Protein flux was $\sim 50 \%$ higher at rest, during exercise and in the post-exercise recovery phase $(\mathrm{P}<0.01)$ in the $\mathrm{CHO}+\mathrm{PRO}$ trial, when compared with the $\mathrm{CHO}$ trial.

Whole-body protein synthesis $\left(\mathrm{mg}\right.$ protein $\left.\cdot \mathrm{kg}^{-1} \cdot \mathrm{h}^{-1}\right)$ in the $\mathrm{CHO}$ and $\mathrm{CHO}+\mathrm{PRO}$ studies is shown in figure 4.3A. Protein synthesis rates were decreased during exercise compared with rates at rest and during post-exercise recovery $(\mathrm{P}<0.01)$. Whole-body protein synthesis tended to be increased at rest $(\mathrm{P}=0.09)$, but was similar during exercise and post-exercise recovery in the $\mathrm{CHO}+\mathrm{PRO}$ trial, when compared with the $\mathrm{CHO}$ trial. 
Protein degradation rates ( $\mathrm{mg}$ protein $\mathrm{kg}^{-1} \cdot \mathrm{h}^{-1}$ ) did not change during exercise (figure 4.3B). A marked decrease in protein breakdown was observed throughout the $\mathrm{CHO}+\mathrm{PRO}$ trial, when compared with the $\mathrm{CHO}$ trial $(\mathrm{P}<0.01)$.

Whole-body protein oxidation ( $\mathrm{mg}$ protein $\mathrm{kg}^{-1} \cdot \mathrm{h}^{-1}$ ) is shown in figure 4.4. Protein oxidation rates were 2-3 fold higher during exercise than at rest and during postexercise recovery $(\mathrm{P}<0.01)$ in the $\mathrm{CHO}$ and $\mathrm{CHO}+\mathrm{PRO}$ trial. In the $\mathrm{CHO}+\mathrm{PRO}$ trial, protein oxidation was increased at rest, during exercise and recovery when compared with the $\mathrm{CHO}$ trial $(\mathrm{P}<0.05)$.

During the $\mathrm{CHO}$ trial whole-body protein balance (mg protein $\left.\cdot \mathrm{kg}^{-1} \cdot \mathrm{h}^{-1}\right)$ was negative at rest, during exercise and during subsequent recovery. Protein balance was more negative during exercise compared with the rest and recovery period $(\mathrm{P}<0.01)$ (figure 4.5). During the $\mathrm{CHO}+\mathrm{PRO}$ trial, protein balance was less negative at rest, during exercise and during post-exercise recovery, when compared with the $\mathrm{CHO}$ trial $(\mathrm{P}<0.01)$, however protein balance during exercise remained negative.

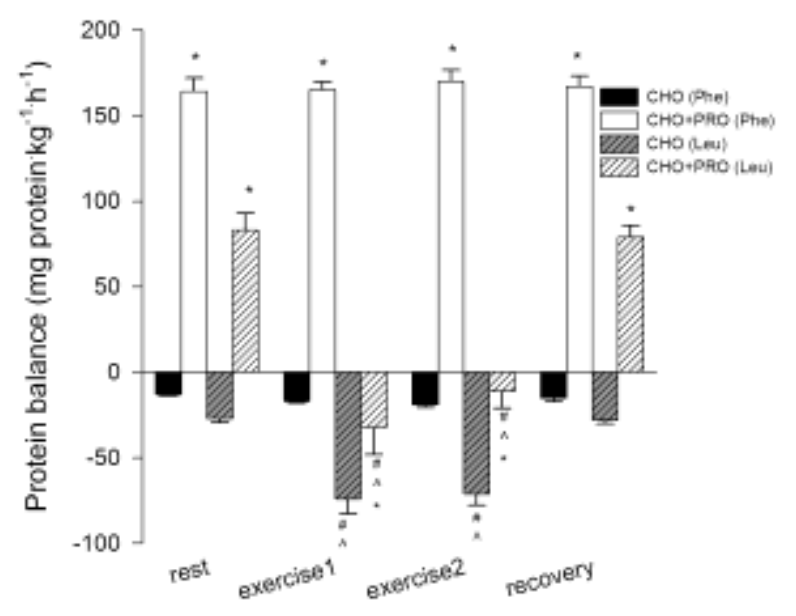

Figure 4.5 Net whole-body protein balance calculated on basis L- $\left[1-{ }^{13} \mathrm{C}\right]$ leucine and $\mathrm{L}-\left[{ }^{2} \mathrm{H}_{5}\right]$ phenylalanine at rest, during exercise 1 and 2 and during recovery. Data are means $\pm \mathrm{SEM} ; \wedge$ significantly different from rest $(\mathrm{P}<0.01)$; \# significantly different from recovery $(\mathrm{P}<0.01){ }^{*}$ significantly different between studies $(\mathrm{P}<0.05)$.

\section{Phenylalanine model vs. leucine model}

The relative increase in protein flux in the $\mathrm{CHO}+\mathrm{PRO}$ trial compared with the $\mathrm{CHO}$ trial was similar for both applied tracers $\left(\mathrm{L}-\left[{ }^{2} \mathrm{H}_{5}\right]\right.$ phenylalanine, $+70 \pm 14 \%$; L-[1-13 $]$ leucine, $+48 \pm 12 \%)$.

Protein synthesis was $69 \pm 14 \%$ increased in the $\mathrm{CHO}+\mathrm{PRO}$ trial compared with the $\mathrm{CHO}$ trial when phenylalanine was used as a tracer. The leucine model showed no differences in protein synthesis rates between trials. 
The relative decrease in protein degradation in the $\mathrm{CHO}+\mathrm{PRO}$ trial compared with the $\mathrm{CHO}$ trial was similar for both applied amino acid tracers (L$\left[{ }^{2} \mathrm{H}_{5}\right]$ phenylalanine, $-55 \pm 11 \%$; L-[1-13 C]leucine, $-62 \pm 8 \%$ ).

Protein oxidation was increased with both tracer models during the $\mathrm{CHO}+\mathrm{PRO}$ trial when compared with the $\mathrm{CHO}$ trial. The relative increase in protein oxidation in the $\mathrm{CHO}+\mathrm{PRO}$ trial compared with the $\mathrm{CHO}$ trial was higher when measured with $\mathrm{L}-\left[1-{ }^{13} \mathrm{C}\right]$ leucine than with $\mathrm{L}-\left[{ }^{2} \mathrm{H}_{5}\right]$ phenylalanine $(190 \pm 30 \%$ vs. $82 \pm 22 \%$, $\mathrm{P}<0.05)$.

Protein balance was improved with both tracer models during the $\mathrm{CHO}+\mathrm{PRO}$ trial when compared with the $\mathrm{CHO}$ trial $(\mathrm{P}<0.05)$. The relative increase in protein balance in the $\mathrm{CHO}+\mathrm{PRO}$ trial compared with the $\mathrm{CHO}$ trial was higher when measured with L- $\left[{ }^{2} \mathrm{H}_{5}\right]$ phenylalanine than with $\mathrm{L}-\left[1-{ }^{13} \mathrm{C}\right]$ leucine $(\mathrm{P}<0.01)$.

\section{Urea model and comparison with other tracers}

Urea kinetics were calculated using a $\left[{ }^{15} \mathrm{~N}_{2}\right]$ urea tracer and results are illustrated in figure 4.6. During the $\mathrm{CHO}$ trial urea production decreased during exercise and recovery compared with resting values, whereas during the $\mathrm{CHO}+\mathrm{PRO}$ trial urea production remained constant. Urea production was higher during the $\mathrm{CHO}+\mathrm{PRO}$ trial compared with the $\mathrm{CHO}$ trial $(\mathrm{P}<0.05)$.

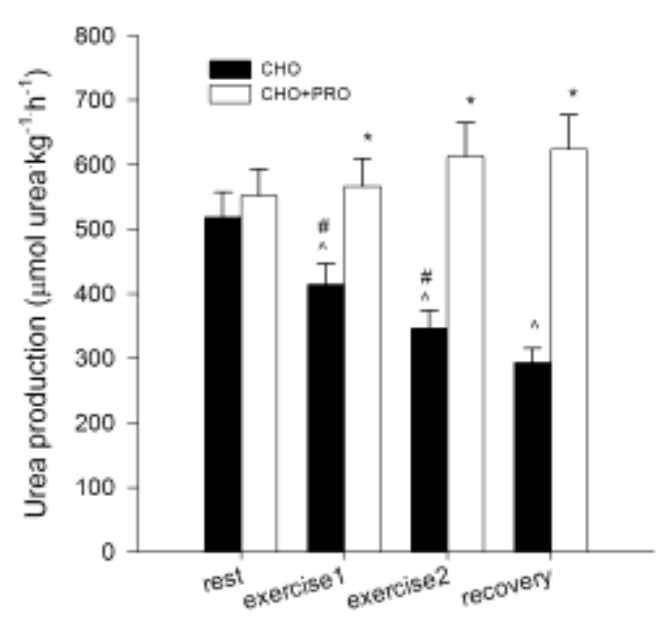

Figure 4.6 Urea production calculated on basis $\left[{ }^{15} \mathrm{~N}_{2}\right]$ urea data at rest, during exercise 1 and 2 and during recovery. Data are means \pm SEM; ${ }^{\wedge}$ significantly different from rest $(\mathrm{P}<0.01)$; \# significantly different from recovery $(\mathrm{P}<0.01) ; *$ significantly different between studies $(\mathrm{P}<0.05)$.

Net protein balance calculated from urea production rates was less negative during exercise and recovery compared with resting values in the $\mathrm{CHO}$ trial $(\mathrm{P}<0.05)$. No changes in net protein balance were observed in the $\mathrm{CHO}+\mathrm{PRO}$ trial. Calculated net protein balance was positive in the $\mathrm{CHO}+\mathrm{PRO}$ trial, whereas during the $\mathrm{CHO}$ trial net protein balance was negative. 
In the $\mathrm{CHO}$ trial, whole-body protein oxidation did not change in time with L$\left[{ }^{2} \mathrm{H}_{5}\right]$ phenylalanine applied as a tracer, increased during exercise with L-[1$\left.{ }^{13} \mathrm{C}\right]$ leucine used as a tracer to return to resting values in the recovery period, and gradually decreased in time with $\left[{ }^{15} \mathrm{~N}_{2}\right]$ urea as tracer. In the $\mathrm{CHO}+\mathrm{PRO}$ trial, whole-body protein oxidation did not change in time with the $\mathrm{L}-\left[{ }^{2} \mathrm{H}_{5}\right]$ phenylalanine and $\left[{ }^{15} \mathrm{~N}_{2}\right]$ urea as tracer and increased during exercise with L- $\left[1-{ }^{13} \mathrm{C}\right]$ leucine as tracer to return to resting values in the recovery period.

Protein balance was improved with all tracer models applied in this trial during the $\mathrm{CHO}+\mathrm{PRO}$ trial when compared with the $\mathrm{CHO}$ trial. The phenylalanine model and the urea model both indicate that the net protein balance is positive in the $\mathrm{CHO}+\mathrm{PRO}$ trial at rest, during exercise and during recovery.

\section{Discussion}

In the present study we show that whole-body estimates of protein metabolism during exercise are highly dependent on the specific tracermethod that is applied. Using L- $\left[1-{ }^{13} \mathrm{C}\right]$ leucine as a tracer to study the effects of exercise on protein metabolism shows that protein oxidation is increased 2-3 fold during exercise. However, when using $\mathrm{L}-\left[{ }^{2} \mathrm{H}_{5}\right]$ phenylalanine as a tracer, protein oxidation, synthesis and degradation rates were not affected by exercise. In addition, urea production, measured using $\left[{ }^{15} \mathrm{~N}_{2}\right]$ urea, decreased in time during the CHO trial. Thus, two of the three methods indicate that prolonged exhaustive exercise does not lead to increased protein oxidation and/or a more negative protein balance. Although the application of different tracer methods produce different outcomes upon the effect of exercise on protein metabolism, each method shows that protein balance is negative when only carbohydrates are ingested. The addition of protein to carbohydrate ingestion improves whole-body protein balance, when measured using both the phenylalanine and the leucine model used in the present study.

Urea production in subjects not ingesting any protein is generally considered a reflection of the amount of amino acids that are released by net protein degradation (degradation - synthesis) and subsequently oxidized with conversion of the amino group to urea. Studies on the effect of exercise on urea production have consistently found no significant change from the basal rate $(7,39,40)$, leading to the conclusion that the rate of net protein catabolism (degradation - synthesis) and amino acid oxidation was not changed. However, data obtained using another approach to determine whole-body protein turnover, involving the infusion of L$\left[1-{ }^{13} \mathrm{C}\right]$ leucine and the determination of leucine turnover and ${ }^{13} \mathrm{CO}_{2}$ appearance in the expired air, indicated that leucine oxidation was markedly increased during exercise $(4,5,39,40)$. Because of this discrepancy between methods, we applied both tracer methods in the same study. In addition, we also applied a third tracer, L- $\left[{ }^{2} \mathrm{H}_{5}\right]$ phenylalanine, which has been successfully applied at rest $(10,27)$, but not during exercise conditions. In contrast to most studies we used an experimental setup, which included exercise and the continuous ingestion of carbohydrate (CHO) or carbohydrate and protein supplements (CHO+PRO) as athletes always ingest carbohydrates during exercise (training or competition) of this duration and 
intensity. With leucine as tracer, protein oxidation was 2 to 3 -fold higher during exercise than in the resting or recovery period (figure 4.4). The widely used L-[1$\left.{ }^{13} \mathrm{C}\right]$ leucine model for the calculation of whole-body protein synthesis and breakdown therefore suggests that exercise inhibits protein synthesis (figure 4.3A). However, with phenylalanine used as tracer, protein oxidation, synthesis and degradation were similar at rest, during exercise and recovery (figure 4.4, 4.3A and $\mathrm{B}$, respectively). Moreover, urea production and the amount of protein oxidation calculated from it also did not increase during exercise (figure 4.6). Thus, both the phenylalanine model and urea data show that prolonged moderate intensity exercise does not lead to an imbalance between protein synthesis and degradation and subsequent oxidation of the liberated amino acids. This is in line with tracer incorporation studies $(8,30)$, which reported no change in muscle protein synthesis both during moderate endurance exercise and recovery. However, results from both the phenylalanine model and the leucine model in the present study show that whole-body protein balance is negative at rest, during exercise and during postexercise recovery when only carbohydrates are ingested (figure 4.5).

A several fold increase in leucine oxidation without changes in urea production during exercise has been previously observed $(39,40)$. Moreover, other studies also showed no effect of exercise on plasma urea concentration (26), production (7) or urinary excretion $(6,18,23)$. An explanation for the discrepancy between the leucine and urea data is that leucine metabolism during exercise is not representative of the fate of the other amino acids that are present in proteins. The stochastic leucine model, therefore, cannot be used to investigate whole-body protein metabolism during exercise. A difference in time response of leucine and urea kinetics theoretically also leads to an apparent absence of an increase in urea production during high rates of leucine oxidation. The urea pool is large and turns over with a half-life of $8-10 \mathrm{~h}(16,19,37)$. This implies that any increase in urea production due to an accelerated protein oxidation rate during exercise should have become apparent either during or following the $6 \mathrm{~h}$ exercise period. However, in the $\mathrm{CHO}$ trial we observed a gradual decrease instead of an increase in urea production over time. Such a decrease in urea production in time has previously been reported in studies at rest after an overnight fast (37). The latter can be attributed to the delayed response of the urea production following changes in protein intake $(16,37)$.

In the present study, we also investigated phenylalanine metabolism. We determined the rate of conversion (hydroxylation) of $\mathrm{L}-\left[{ }^{2} \mathrm{H}_{5}\right]$ phenylalanine to L$\left[{ }^{2} \mathrm{H}_{4}\right]$ tyrosine at rest, during exercise and during recovery. This is the first step of phenylalanine oxidation and we found that its rate did not change during exercise and/or recovery in comparison to the resting state. This is in line with findings reported by Wolfe et al. (40) using a lysine tracer. In the latter study the increase in lysine oxidation during exercise was small compared with the increase in leucine oxidation. In addition, a discrepancy existed between the $\left[{ }^{15} \mathrm{~N}\right]-$ and $\left[{ }^{13} \mathrm{C}\right]$ lysine flux data and the $\left[{ }^{13} \mathrm{C}\right]-$ and $\left[{ }^{15} \mathrm{~N}\right]$ leucine flux data, which is similar to the discrepancy between phenylalanine and leucine observed in the present study. 
One of the likely causes of the discrepancy between the lysine and/or phenylalanine tracer and the leucine tracer methods is the fact that during exercise, uptake $(1,32)$ and oxidation $(32,34,35)$ of branched chain amino acids (leucine, isoleucine and valine) are increased several fold in contracting muscle. As such, the leucine tracer does not seem to be representative of the fate of the other essential amino acids during exercise. The latter means that the stochastic leucine model of whole-body protein metabolism (20) becomes invalid during exercise and cannot be used to estimate qualitative or quantitative changes in whole-body protein synthesis and/or degradation.

Most studies measuring protein turnover during exercise were performed in the morning after an overnight fast, which does not represent every day practice in the competitive athletes. Athletes optimize carbohydrate availability before and during exercise to enhance endurance performance capacity. During subsequent recovery they ingest mixed meals or carbohydrate/protein recovery drinks. The present study demonstrates that net protein degradation does not increase during moderate intensity exercise when carbohydrate is ingested. This implies that net protein breakdown and oxidation is minimal during athletic events such as (ultra)marathons and prolonged cycling races when carbohydrate is ingested. Although protein degradation and synthesis are unaltered by exercise when $\mathrm{CHO}$ $\left(0.7 \mathrm{~g} \cdot \mathrm{kg}^{-1} \cdot \mathrm{h}^{-1}\right)$ are ingested, whole-body protein balance measured with L$\left[{ }^{2} \mathrm{H}_{5}\right]$ phenylalanine was slightly negative during exercise and during recovery in the present study. However, the imbalance between protein synthesis and degradation and the amount of protein oxidized was not larger than in the resting state (figure 4.5).

It has previously been shown that infusion or ingestion of amino acids alone or in combination with carbohydrate increases protein synthesis and reduces protein degradation both at a whole-body level and in skeletal muscle tissue under resting conditions $(12,15,22)$ and after resistance exercise $(2,3,24,28,29)$, resulting in a positive protein balance. We aimed to investigate whether the addition of protein to a carbohydrate supplement can improve whole-body protein balance during and following prolonged endurance exercise leading to a (more) positive protein balance, as previously observed in the resting state. Combined ingestion of protein and carbohydrate resulted in an increased whole-body protein synthesis rate at rest, during exercise and recovery when compared with carbohydrate supplementation only. Although protein oxidation was increased $\sim 2$ fold at rest, during exercise and recovery with the protein supplement, whole-body protein degradation decreased by $\sim 60 \%$. Thus, the present study shows that the combined ingestion of protein and carbohydrate improves net protein balance at rest, during prolonged moderate intensity exercise and subsequent recovery in elite endurance athletes. With phenylalanine and urea as tracer a positive net protein balance was achieved, whereas ingestion of only carbohydrate resulted in a negative protein balance.

The L- $\left[{ }^{2} \mathrm{H}_{5}\right]$ phenylalanine tracer method indicate that protein flux and oxidation rates are increased as expected when protein is orally ingested. In addition, coingestion of protein with carbohydrate results in a decreased rate of protein degradation and improved protein balance. The $\left[{ }^{15} \mathrm{~N}_{2}\right]$ urea tracer provides a similar 
outcome upon the effect of exercise on net protein balance as the L$\left[{ }^{2} \mathrm{H}_{5}\right]$ phenylalanine tracer. Urea production slightly increases when protein is ingested (figure 4.6). This is due to the fact that more protein is ingested than is used for protein synthesis. The excess is directly oxidized or used for gluconeogenesis and/or lipogenesis with the aminogroup being disposed as urea. The balance between protein synthesis and degradation calculated from the difference between urea production observed and the urea equivalent of the ingested amount of protein (table 4.2) indicates that there is net positive protein balance, which is quantitatively similar to the estimates made from the figures generated by the phenylalanine tracer both at rest, during exercise and during recovery. This implies that the information generated by the phenylalanine tracer and urea tracer on the effect of protein ingestion is similar in all time periods studied, while the leucine data generate a different message during exercise (positive balance at rest and during recovery and negative balance during exercise). In summary, this study shows that the L- $\left[{ }^{2} \mathrm{H}_{5}\right]$ phenylalanine, L- $\left[1-{ }^{13} \mathrm{C}\right]$ leucine and $\left[{ }^{15} \mathrm{~N}_{2}\right]$ urea tracers models reveal the same qualitative effect of the combined ingestion of protein and carbohydrate on whole-body protein balance at rest and during recovery. However, the $\mathrm{L}-\left[1-{ }^{13} \mathrm{C}\right]$ leucine model for measurements of wholebody protein turnover overestimates protein oxidation rates and underestimate protein synthesis rates during exercise. We conclude that prolonged exhaustive moderate intensity exercise does not result in increased protein degradation and/or a decrease in protein synthesis compared with resting situations in endurancetrained athletes. Whereas whole-body protein balance remains negative when only carbohydrates are ingested, co-ingestion with protein improves protein balance by increasing synthesis and decreasing breakdown, resulting in a positive net protein balance both at rest, during prolonged moderate intensity exercise and during recovery.

\section{Acknowledgements}

We gratefully acknowledge the analytic assistance of Jos Stegen and the enthusiastic support of the subjects who volunteered to participate in these studies. Anton Wagenmakers and Asker Jeukendrup are currently working at the School of Sport and Exercise Sciences, University of Birmingham, Birmingham, B15 2TT, United Kingdom. David Halliday is currently working at the Tropical Metabolism Research Unit, University of the West Indies, Mona, Kingston 7, Jamaica. 


\section{References}

1. Ahlborg G, Felig P, Hagenfeldt L, Hendler R, and Wahren J. Substrate turnover during prolonged exercise in man. Splanchnic and leg metabolism of glucose, free fatty acids, and amino acids. J Clin Invest 53: 1080-1090, 1974.

2. Biolo G, Tipton KD, Klein S, and Wolfe RR. An abundant supply of amino acids enhances the metabolic effect of exercise on muscle protein. Am J Physiol 273: E122129, 1997.

3. Borsheim E, Tipton KD, Wolf SE, and Wolfe RR. Essential amino acids and muscle protein recovery from resistance exercise. Am J Physiol Endocrinol Metab 283: E648657, 2002.

4. Bowtell JL, Leese GP, Smith K, Watt PW, Nevill A, Rooyackers O, Wagenmakers AJ, and Rennie MJ. Effect of oral glucose on leucine turnover in human subjects at rest and during exercise at two levels of dietary protein. J Physiol $525 \mathrm{Pt}$ 1: 271-281, 2000.

5. Bowtell JL, Leese GP, Smith K, Watt PW, Nevill A, Rooyackers O, Wagenmakers AJ, and Rennie MJ. Modulation of whole-body protein metabolism, during and after exercise, by variation of dietary protein. J Appl Physiol 85: 1744-1752, 1998.

6. Carraro F, Hartl WH, Stuart CA, Layman DK, Jahoor F, and Wolfe RR. Whole-body and plasma protein synthesis in exercise and recovery in human subjects. Am J Physiol 258: E821-831, 1990.

7. Carraro F, Kimbrough TD, and Wolfe RR. Urea kinetics in humans at two levels of exercise intensity. J Appl Physiol 75: 1180-1185, 1993.

8. Carraro F, Stuart CA, Hartl WH, Rosenblatt J, and Wolfe RR. Effect of exercise and recovery on muscle protein synthesis in human subjects. Am J Physiol 259: E470-476, 1990.

9. Cathcart EP. The influence of muscle work on protein metabolism. Physiol Rev 5: 225-243, 1925.

10. Clarke JT and Bier DM. The conversion of phenylalanine to tyrosine in man. Direct measurement by continuous intravenous tracer infusions of L-[ring-2H5]phenylalanine and L-[1-13C] tyrosine in the postabsorptive state. Metabolism 31: 999-1005, 1982.

11. Coggan AR, Habash DL, Mendenhall LA, Swanson SC, and Kien CL. Isotopic estimation of $\mathrm{CO} 2$ production during exercise before and after endurance training. J Appl Physiol 75: 70-75, 1993.

12. Collin-Vidal C, Cayol M, Obled C, Ziegler F, Bommelaer G, and Beaufrere B. Leucine kinetics are different during feeding with whole protein or oligopeptides. Am J Physiol 267: E907-914, 1994.

13. Decombaz J, Reinhardt P, Anantharaman K, von Glutz G, and Poortmans JR. Biochemical changes in a $100 \mathrm{~km}$ run: free amino acids, urea, and creatinine. Eur J Appl Physiol Occup Physiol 41: 61-72, 1979.

14. Fick A and Wislecenus J. On the origin of muscular power. Philos Mag 31: 485-503, 1866.

15. Fryburg DA, Jahn LA, Hill SA, Oliveras DM, and Barrett EJ. Insulin and insulin-like growth factor-I enhance human skeletal muscle protein anabolism during hyperaminoacidemia by different mechanisms. J Clin Invest 96: 1722-1729., 1995.

16. Jones EA, Craigie A, Tavill AS, Simon W, and Rosenoer VM. Urea kinetics and the direct measurement of the synthetic rate of albumin utilizing [14C]carbonate. Clin Sci 35: 553-564, 1968. 
17. Kuipers H, Verstappen FT, Keizer HA, Geurten P, and van Kranenburg G. Variability of aerobic performance in the laboratory and its physiologic correlates. Int J Sports Med 6: 197-201, 1985.

18. Lemon PW and Mullin JP. Effect of initial muscle glycogen levels on protein catabolism during exercise. J Appl Physiol 48: 624-629, 1980.

19. Matthews DE and Downey RS. Measurement of urea kinetics in humans: a validation of stable isotope tracer methods. Am J Physiol 246: E519-527, 1984.

20. Matthews DE, Motil KJ, Rohrbaugh DK, Burke JF, Young VR, and Bier DM. Measurement of leucine metabolism in man from a primed, continuous infusion of L[1-13C]leucine. Am J Physiol 238: E473-479, 1980.

21. Munro HN and Fleck A. Analysis of tissues and body fluids for nitrogenous constituents. In: Mammalian Protein Metabolism, edited by Munro HN. New York: Academic, 1969, p. 423-525.

22. Pacy PJ, Garrow JS, Ford GC, Merritt H, and Halliday D. Influence of amino acid administration on whole-body leucine kinetics and resting metabolic rate in postabsorptive normal subjects. Clin Sci (Lond) 75: 225-231, 1988.

23. Phillips SM, Atkinson SA, Tarnopolsky MA, and MacDougall JD. Gender differences in leucine kinetics and nitrogen balance in endurance athletes. J Appl Physiol 75: 21342141, 1993.

24. Rasmussen BB, Tipton KD, Miller SL, Wolf SE, and Wolfe RR. An oral essential amino acid-carbohydrate supplement enhances muscle protein anabolism after resistance exercise. J Appl Physiol 88: 386-392., 2000.

25. Rennie MJ, Edwards RH, Krywawych S, Davies CT, Halliday D, Waterlow JC, and Millward DJ. Effect of exercise on protein turnover in man. Clin Sci (Lond) 61: 627639, 1981.

26. Stein TP, Hoyt RW, Toole MO, Leskiw MJ, Schluter MD, Wolfe RR, and Hiller WD. Protein and energy metabolism during prolonged exercise in trained athletes. Int J Sports Med 10: 311-316, 1989.

27. Thompson GN, Pacy PJ, Merritt H, Ford GC, Read MA, Cheng KN, and Halliday D. Rapid measurement of whole-body and forearm protein turnover using a [2H5]phenylalanine model. Am J Physiol 256: E631-639, 1989.

28. Tipton KD, Borsheim E, Wolf SE, Sanford AP, and Wolfe RR. Acute response of net muscle protein balance reflects 24-h balance after exercise and amino acid ingestion. Am J Physiol Endocrinol Metab 284: E76-89, 2003.

29. Tipton KD, Ferrando AA, Phillips SM, Doyle D, Jr., and Wolfe RR. Post-exercise net protein synthesis in human muscle from orally administered amino acids. Am J Physiol 276: E628-634, 1999.

30. Tipton KD, Ferrando AA, Williams BD, and Wolfe RR. Muscle protein metabolism in female swimmers after a combination of resistance and endurance exercise. J Appl Physiol 81: 2034-2038, 1996.

31. van Acker BA, Hulsewe KW, Wagenmakers AJ, Soeters PB, and von Meyenfeldt MF. Glutamine appearance rate in plasma is not increased after gastrointestinal surgery in humans. J Nutr 130: 1566-1571, 2000.

32. van Hall G, MacLean DA, Saltin B, and Wagenmakers AJ. Mechanisms of activation of muscle branched-chain alpha-keto acid dehydrogenase during exercise in man. J Physiol 494: 899-905, 1996.

33. Von Liebig J. Animal chemistry or organic chemistry in its application to physiology. London: Taylor and Walton, 1842. 
34. Wagenmakers AJ, Beckers EJ, Brouns F, Kuipers H, Soeters PB, van der Vusse GJ, and Saris WH. Carbohydrate supplementation, glycogen depletion, and amino acid metabolism during exercise. Am J Physiol 260: E883-890, 1991.

35. Wagenmakers AJ, Brookes JH, Coakley JH, Reilly T, and Edwards RH. Exerciseinduced activation of the branched-chain 2-oxo acid dehydrogenase in human muscle. Eur J Appl Physiol Occup Physiol 59: 159-167, 1989.

36. Wagenmakers AJ, Rehrer NJ, Brouns F, Saris WH, and Halliday D. Breath 13CO2 background enrichment during exercise: diet-related differences between Europe and America. J Appl Physiol 74: 2353-2357, 1993.

37. Waterlow JC. The Mysteries of Nitrogen Balance. Nutr Res Rev 12: 25-54, 1999.

38. Wolfe RR. Radioactive and stable isotope tracers in biomedicine: principles and practice of kinetic analysis. New York: Wiley-Liss, 1992.

39. Wolfe RR, Goodenough RD, Wolfe MH, Royle GT, and Nadel ER. Isotopic analysis of leucine and urea metabolism in exercising humans. J Appl Physiol 52: 458-466, 1982.

40. Wolfe RR, Wolfe MH, Nadel ER, and Shaw JH. Isotopic determination of amino acidurea interactions in exercise in humans. J Appl Physiol 56: 221-229, 1984. 


\section{5}

The combined ingestion of protein and free leucine with carbohydrate increases postexercise muscle protein synthesis in vivo in male subjects

René Koopman, Anton J.M. Wagenmakers, Ralph J.F. Manders, Antoine H.G. Zorenc, Joan M.G. Senden, Marchel Gorselink, Hans A. Keizer, and Luc J.C. van Loon

Am J Physiol Endocrinol Metab (2005). 288:E645-53 


\begin{abstract}
The present study was designed to determine post-exercise muscle protein synthesis and whole-body protein balance following the combined ingestion of carbohydrate with or without protein and/or free leucine. Eight male subjects were randomly assigned to 3 trials in which they consumed drinks containing either carbohydrate $(\mathrm{CHO})$, carbohydrate and protein $(\mathrm{CHO}+\mathrm{PRO})$, or carbohydrate, protein and free leucine $(\mathrm{CHO}+\mathrm{PRO}+\mathrm{leu})$ following $45 \mathrm{~min}$ of resistance exercise. A primed, continuous infusion of $\mathrm{L}-\left[\mathrm{ring}-{ }^{13} \mathrm{C}_{6}\right]$ phenylalanine was applied, with blood samples and muscle biopsies collected to assess fractional synthetic rate (FSR) in the $\mathrm{m}$. vastus lateralis as well as whole-body protein turnover during $6 \mathrm{~h}$ of post-exercise recovery. Plasma insulin response was higher in the $\mathrm{CHO}+\mathrm{PRO}+\mathrm{leu}$ compared to the $\mathrm{CHO}$ and $\mathrm{CHO}+\mathrm{PRO}$ trials $(+240 \pm 19 \%$ and $+77 \pm 11 \%$, respectively, $\mathrm{P}<0.05)$. Whole-body protein breakdown rates were lower, and whole-body protein synthesis rates were higher in the $\mathrm{CHO}+\mathrm{PRO}$ and $\mathrm{CHO}+\mathrm{PRO}+$ leu trials compared to the $\mathrm{CHO}$ trial $(\mathrm{P}<0.05)$. Addition of leucine in the $\mathrm{CHO}+\mathrm{PRO}+$ leu trial resulted in a lower protein oxidation rate compared to the $\mathrm{CHO}+\mathrm{PRO}$ trial. Protein balance was negative during recovery in the $\mathrm{CHO}$ trial, but positive in the $\mathrm{CHO}+\mathrm{PRO}$ and $\mathrm{CHO}+\mathrm{PRO}+$ leu trials. In the $\mathrm{CHO}+\mathrm{PRO}+$ leu trial, whole-body net protein balance was significantly greater compared to values observed in the $\mathrm{CHO}+\mathrm{PRO}$ and $\mathrm{CHO}$ trials $(\mathrm{P}<0.05)$. Mixed muscle fractional synthetic rate, measured over a $6 \mathrm{~h}$ period of post-exercise recovery, was significantly greater in the $\mathrm{CHO}+\mathrm{PRO}+$ leu trial compared to the CHO trial $\left(0.095 \pm 0.006 \% \cdot \mathrm{h}^{-1}\right.$ vs. $0.061 \pm 0.008 \% \cdot \mathrm{h}^{-1}$, respectively; $\left.\mathrm{P}<0.05\right)$, with intermediate values observed in the $\mathrm{CHO}+\mathrm{PRO}$ trial $\left(0.0820 \pm 0.0104 \% \cdot \mathrm{h}^{-1}\right)$. We conclude that the co-ingestion of protein and leucine stimulates muscle protein synthesis and optimizes whole-body protein balance when compared to the intake of carbohydrate only.
\end{abstract}




\section{Introduction}

Resistance training can substantially augment skeletal muscle size and it has been shown that after resistance exercise, mixed muscle protein synthesis is stimulated for up to $48 \mathrm{~h}(12,35)$. Simultaneously, the rate of muscle protein degradation is also increased after exercise $(7,35)$. However, in the absence of food intake net muscle protein balance remains negative $(7,35,36)$. Carbohydrate supplementation in the post-exercise recovery phase has been shown to result in a decrease in urinary 3-methylhistidine and urea excretion, suggesting that protein degradation is reduced (40). However, muscle protein synthesis does not seem to be affected following carbohydrate ingestion $(10,40)$. Although carbohydrate ingestion improves net leg amino acid balance compared with water or placebo intake, the net balance remains negative (10). It has been shown using different tracer methods/models (e.g. tracer incorporation measurements in muscle, leg amino acid exchange methods or whole-body measurements) that the combined infusion or ingestion of carbohydrate and protein/amino acids is needed to increase protein synthesis rate, to reduce protein degradation, and thus to elicit a positive net protein balance under resting conditions (13, 33) and during recovery from resistance exercise $(8,11,39,43,44)$. Moreover, in a recent study $(25)$, we have shown that the combined ingestion of protein and carbohydrate leads to a positive protein balance during ultra endurance exercise and subsequent recovery. The combined ingestion of carbohydrate and protein/amino acids in the post-exercise recovery phase can stimulate protein metabolism in several ways. Besides providing amino acids as precursors for protein synthesis, combined ingestion of carbohydrate and protein/amino acids can elicit a strong insulinotropic response $(34,38,49)$.

Combined ingestion of carbohydrate with protein and/or free amino acids $(34,38$, 47-49), as well as intravenous infusion of free amino acids $(16,17)$ has been shown to further elevate plasma insulin levels. It has been speculated that such elevated insulin concentrations can stimulate the uptake of selected amino acids (6) and muscle protein synthesis rate $(6,20)$. In addition, insulin has been reported to effectively inhibit proteolysis (9, 18, 19). Nonetheless, the exact mechanisms responsible for the stimulatory effects of carbohydrate and protein/amino acid ingestion on muscle protein synthesis during recovery from resistance exercise have not yet been established in detail. For example, in animal models, free leucine has been shown to stimulate protein synthesis by an insulin-independent mechanism (2, 3). Consequently, it has been speculated that a nutritional supplement containing carbohydrate, protein and free leucine could represent an effective tool to further increase post-exercise muscle protein synthesis and/or to inhibit protein degradation.

The main aim of the present study was to investigate the effect of carbohydrate (CHO), carbohydrate and protein $(\mathrm{CHO}+\mathrm{PRO})$ as well as carbohydrate, protein and leucine $(\mathrm{CHO}+\mathrm{PRO}+\mathrm{leu})$ ingestion on the anabolic response to resistance exercise. By measuring the incorporation rate of labeled amino acids in the skeletal 
muscle protein pool, mixed muscle protein synthesis rates were directly measured during $6 \mathrm{~h}$ of recovery from strenuous resistance exercise. A primed constant infusion of $\mathrm{L}$-[ring- $\left.{ }^{13} \mathrm{C}_{6}\right]$ phenylalanine was combined with plasma and muscle tissue sampling to simultaneously measure mixed muscle fractional protein synthetic rate and whole-body protein turnover.

\section{Methods}

\section{Subjects}

8 healthy, untrained male volunteers (age: $22.3 \pm 0.9$ y; weight: $74.1 \pm 3.5 \mathrm{~kg}$; height: 1.81 $\pm 0.02 \mathrm{~m}$; BMI: $22.5 \pm 0.9 \mathrm{~kg} \cdot \mathrm{m}^{-2} ; \%$ body fat: $16.0 \pm 3 \%$, with no history of participating in any regular exercise program, were recruited for the present study. All subjects were informed on the nature and possible risks of the experimental procedures before their informed consent was obtained. The latter after approval by the Medical Ethical Committee of the Academic Hospital Maastricht, The Netherlands.

\section{Pretesting}

All subjects participated in an orientation trial to become familiarized with the exercise protocol and the equipment. Proper lifting technique was demonstrated and practiced for each of the 2 lower-limb exercises (leg press and leg extension). Thereafter maximum strength was estimated using the multiple repetitions testing procedure (29). In another session, at least $1 \mathrm{wk}$ before the first experimental trial, subjects' 1 repetition maximum (1RM) was determined (26). After warming up, the load was set at 90-95\% of the estimated 1RM, and increased after each successful lift until failure. A five-minute resting period between the subsequent attempts was allowed. A repetition was valid if the subject was able to complete the entire lift in a controlled manner without assistance. The average 1RM for the leg press was $185 \pm 9 \mathrm{~kg}$ and the mean $1 \mathrm{RM}$ for the leg extension was $106 \pm 4 \mathrm{~kg}$.

\section{Diet and activity prior to testing}

All subjects consumed a standardized meal $\left(66.1 \pm 2.7 \mathrm{~kJ} \cdot \mathrm{kg}^{-2}\right.$, consisting of 72 Energy\% (En\%) carbohydrate, $23 \mathrm{En} \%$ protein and $5 \mathrm{En} \%$ fat) the evening before the trials. All volunteers were instructed to refrain from any sort of heavy physical exercise and to keep their diet as constant as possible 3 days before the trials. In addition, subjects were asked to record their food intake for $48 \mathrm{~h}$ before the start of the first experimental trial and to consume the same diet $48 \mathrm{~h}$ before the start of the second and third test. 


\section{Experimental trials}

Each subject participated in 3 trials, separated by at least 7 days, in which recovery drinks containing either carbohydrate $(\mathrm{CHO})$, carbohydrate and protein $(\mathrm{CHO}+\mathrm{PRO})$ or carbohydrate, protein and leucine $(\mathrm{CHO}+\mathrm{PRO}+\mathrm{leu})$ were tested in a randomized and double-blind fashion. Each trial lasted $\sim 8 \mathrm{~h}$. Repeated boluses of a given test-drink were ingested following the exercise protocol to ensure a continuous supply of ample glucose and amino acids to the muscle. Plasma and muscle samples were collected during a $6 \mathrm{~h}$ post-exercise period. These trials were designed to simultaneously assess whole-body amino acid kinetics and fractional synthetic rate (FSR) of mixed muscle protein by the incorporation of L-[ring$\left.{ }^{13} \mathrm{C}_{6}\right]$ phenylalanine in the $\mathrm{m}$. vastus lateralis.

\section{Protocol}

At $8.00 \mathrm{am}$, after an overnight fast, subjects reported at the laboratory and a Teflon catheter was inserted into an antecubital vein for stable isotope infusion. A second Teflon catheter was inserted in a heated dorsal hand vein of the contralateral arm, which was placed in a hot-box $\left(60^{\circ} \mathrm{C}\right)$ for arterialized blood sampling. After collection of a resting blood sample, a single intravenous dose of L-[ring$\left.{ }^{13} \mathrm{C}_{6}\right]$ phenylalanine $\left(2 \mu \mathrm{mol} \cdot \mathrm{kg}^{-1}\right)$ was administered to prime the phenylalanine pool. Thereafter, tracer infusion was started with subjects resting in a supine position. After 75 min of infusion, a second blood sample was collected and subjects started the resistance exercise protocol. The exercise session consisted of 8 sets of 8 repetitions on the horizontal leg press machine (Technogym BV, Rotterdam, The Netherlands) and 8 sets of 8 repetitions on the leg extension machine (Technogym). Both exercises were performed at $80 \%$ of the subjects' individual 1RM with 2 min rest intervals between the sets and in total required $\sim 45$ min to complete. All subjects were verbally encouraged during the test to complete the whole protocol. At the end of the resistance exercise protocol ( $\mathrm{t}=0 \mathrm{~min})$, subjects rested supine and a arterialized blood sample from the heated hand vein as well as a muscle biopsy from the $\mathrm{m}$. vastus lateralis muscle were collected. Subjects then received an initial bolus $\left(3 \mathrm{ml} \cdot \mathrm{kg}^{-1}\right)$ of a given test drink. Repeated drinks $\left(3 \mathrm{ml} \cdot \mathrm{kg}^{-1}\right)$ were taken every $30 \mathrm{~min}$ until $\mathrm{t}=330 \mathrm{~min}$ post-exercise. Blood samples were subsequently taken from the heated hand vein at $\mathrm{t}=15,30,45,60,75,90,120,150$, $180,210,240,270,300,330$ and 360 min with an additional muscle biopsy taken at 360 min post-exercise.

\section{Muscle biopsies}

Muscle biopsies were obtained from the middle region of the $\mathrm{m}$. vastus lateralis (15 $\mathrm{cm}$ above the patella) and approximately $2 \mathrm{~cm}$ below entry through the fascia using the percutaneous needle biopsy technique (5). Muscle samples were immediately freed from blood, visible fat and connective tissue, and rapidly frozen in liquid nitrogen, and stored at $-80^{\circ} \mathrm{C}$ for measurement of the amino acid enrichment in the muscle free amino acid pool and in mixed muscle protein. 


\section{Beverages}

Subjects received a beverage volume of $3 \mathrm{ml} \cdot \mathrm{kg}^{-1}$ every 30 minutes to ensure a given dose of $0.3 \mathrm{~g}$ carbohydrate $\mathrm{kg}^{-1}(50 \%$ as glucose and $50 \%$ as maltodextrin) and $0.2 \mathrm{~g} \cdot \mathrm{kg}^{-1}$ of a protein hydrolysate every $\mathrm{h}$, with or without the addition of 0.1

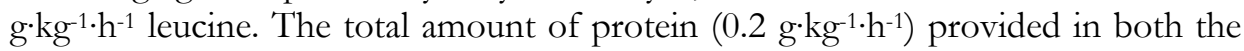
$\mathrm{CHO}+\mathrm{PRO}$ and $\mathrm{CHO}+\mathrm{PRO}+$ leu trials by far exceeded the calculated amount of protein that was estimated to provide sufficient precursor substrate to sustain maximal protein synthesis rates for at least $6 \mathrm{~h}$ (50). Repeated boluses were administered to enable a continuous ample supply of amino acids in the circulation, preventing perturbations in L-[ring- $\left.{ }^{13} \mathrm{C}_{6}\right]$ phenylalanine enrichments. The whey protein hydrolysate used in the present study contained $9.95 \%$ leucine and consequently the total amount of leucine administered in the $\mathrm{CHO}+\mathrm{PRO}$ and

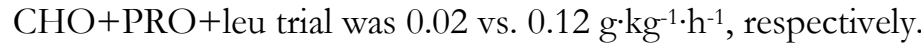

The compositions of all test drinks are listed in table 5.1. Glucose and maltodextrin were obtained from AVEBE (Veendam, The Netherlands). Whey protein hydrolysate was prepared by Numico Research (Wageningen, The Netherlands). Leucine was purchased from BUFA (Uitgeest, The Netherlands). To make the taste comparable in all trials, beverages were uniformly flavored by adding $0.2 \mathrm{~g}$ sodium-saccharinate solution (25\% w/w), $1.8 \mathrm{~g}$ citric acid solution $(50 \% \mathrm{w} / \mathrm{w})$ and $5 \mathrm{~g}$ of cream vanilla flavor (Numico Research) for each liter of beverage. Trials were performed in a randomized order, with test-drinks provided in a double-blind fashion.

Table 5.1 Composition of beverages

\begin{tabular}{lccc}
\hline Test drink & CHO & CHO+PRO & CHO+PRO+leu \\
\hline Whey protein & - & 33.3 & 33.3 \\
Leucine & - & - & 16.6 \\
Glucose & 25 & 25 & 25 \\
Maltodextrin & 25 & 25 & 25 \\
Sodium saccharinate & 0.2 & & \\
Citric acid & 1.8 & 0.2 & 0.2 \\
Cream vanilla & 5 & 1.8 & 1.8 \\
& & 5 & 5 \\
Water & up to $1.00 \mathrm{~L}$ & & \\
\hline
\end{tabular}

Values expressed in $g \cdot \mathrm{L}^{-1}$ beverage.

\section{Tracer infusion}

L-[ring- ${ }^{13} \mathrm{C}_{6}$ ]phenylalanine $(99 \%$ enriched, Cambridge Isotopes, Andover, MA, USA) was dissolved in $0.9 \%$ saline before infusion. The phenylalanine pool was 
primed with an infusion dose of $2 \mu \mathrm{mol} \cdot \mathrm{kg}^{-1}$. Thereafter, continuous intravenous infusion of the isotopes was performed using a calibrated IVAC 560 pump (San Diego, CA, USA) with an average infusion rate of $0.046 \pm 0.001 \mu \mathrm{mol} \cdot \mathrm{kg}^{-1} \cdot \mathrm{min}^{-1}$.

\section{Analysis}

Blood samples were collected in EDTA containing tubes and centrifuged at $1000 \mathrm{~g}$ and $4^{\circ} \mathrm{C}$ for $5 \mathrm{~min}$. Aliquots of plasma were frozen in liquid nitrogen and stored at $-80^{\circ} \mathrm{C}$. Insulin was analyzed by radio immunoassay (Insulin RIA kit, LINCO Research Inc., St. Charles, MO, USA). Plasma $(500 \mu \mathrm{L})$ for amino acid analysis was deproteonized on ice with $100 \mu \mathrm{L}$ of $24 \%$ (w/v) 5-sulphosalicylic acid, mixed (vortexing) and the clear supernatant was collected after centrifugation. Plasma amino acid concentrations were analyzed on an automated dedicated amino acid analyzer (LC-A10, Shimadzu Benelux, Den Bosch, The Netherlands), using an automated precolumn derivatization procedure and a ternary solvent system (15). The exact phenylalanine concentration in the infusates $\left(8.06 \pm 0.21 \mathrm{mmol} \cdot \mathrm{L}^{-1}\right)$ was measured using the same method. Plasma phenylalanine and tyrosine were derivatized to their tert-butyldimethylsilyl (TBDMS) derivatives and their ${ }^{13} \mathrm{C}$ enrichments were determined by electron ionization gas chromatography-mass spectrometry (GC-MS, Finnigan Incos XL) using selected ion monitoring of masses 336 and 342 for unlabeled and labeled phenylalanine respectively and masses 466 and 472 for unlabeled and labeled tyrosine (51).

For measurement of L-[ring- $\left.{ }^{13} \mathrm{C}_{6}\right]$ phenylalanine enrichment in the free amino acid pool and mixed muscle protein, $55 \mathrm{mg}$ of wet muscle was freeze-dried. Collagen, blood and other non-muscle fiber material were removed from the muscle fibers under a light microscope. The isolated muscle fiber mass (2-3 mg) was weighed and $2 \mathrm{ml}$ of ice-cold 2\% perchloric acid (PCA) was added. The tissue was then homogenized and centrifuged. The supernatant was collected and processed in the same manner as the plasma samples, such that intracellular free L-[ring${ }^{13} \mathrm{C}_{6}$ ] phenylalanine and L-[ring- ${ }^{13} \mathrm{C}_{6}$ ] tyrosine enrichments could be measured using their t-butyldimethylsilyl derivatives on a GCMS. The protein pellet was washed with 3 additional $2 \mathrm{ml}$ washes of $2 \%$ PCA, dried and the proteins were hydrolyzed in $6 \mathrm{M} \mathrm{HCl}$ at $120^{\circ} \mathrm{C}$ for $15-18 \mathrm{~h}$. The hydrolyzed protein fraction was dried under a nitrogen stream while heated to $120^{\circ} \mathrm{C}$, then dissolved in a $50 \%$ acetic acid solution and passed over a Dowex exchange resin (AG 50W-X8, 100-200 mesh hydrogen form, Biorad, Hercules, CA, USA) using $2 \mathrm{M} \mathrm{NH}_{4} \mathrm{OH}$. Thereafter, the eluate was dried and the purified amino acid fraction was derivatized into the $\mathrm{N}$-acetyl-methyl (NAM)-esters to determine the ${ }^{13} \mathrm{C}$-enrichment of protein bound phenylalanine enrichment using GC-IRMS (Finnigan, MAT 252).

\section{Calculations}

Infusion of L-[ring- $\left.{ }^{13} \mathrm{C}_{6}\right]$ phenylalanine with muscle and arterialized blood sampling was used to simultaneously assess whole-body amino acid kinetics and FSR of mixed muscle protein. Whole-body rates of appearance $(\mathrm{Ra})$ and disappearance 
(Rd) of phenylalanine were calculated using the non-steady state Steele equations adapted for stable isotope methodology (41).

$$
\begin{aligned}
& R_{a}=\frac{F-{ }^{\prime}\left[\left(C_{2}+\tau_{1}\right) / 2\right]\left[\left(E_{2}-z_{1}\right) /\left(t_{2}-{ }_{1}\right)\right]}{\left(E_{2}\right.}+\overline{\left.z_{1}\right) / 2} \\
& R_{d}=R_{a}-V \cdot\left(\frac{C_{2}-C_{1}}{t_{2}}-t_{1}\right)
\end{aligned}
$$

where $F$ is the infusion rate $\left(\mu \mathrm{mol} \cdot \mathrm{kg}^{-1} \cdot \mathrm{min}^{-1}\right) ; \mathrm{V}=$ distribution volume for phenylalanine $\left(125 \mathrm{ml} \cdot \mathrm{kg}^{-1}\right)(14)$; $\mathrm{C} 1$ and $\mathrm{C} 2$ are the phenylalanine concentrations $\left(\mathrm{mmol} \cdot \mathrm{L}^{-1}\right)$ in arterialized plasma at time $1(\mathrm{t} 1)$ and $2(\mathrm{t} 2)$, respectively and $\mathrm{E} 1$ and E2 are the plasma L-[ring- $\left.{ }^{13} \mathrm{C}_{6}\right]$ phenylalanine enrichments (expressed in tracertracee ratio; TTR). As whole-body Ra comprise phenylalanine rate of appearance arising from protein breakdown (B) and protein intake (I), whole-body protein breakdown can be calculated as follows.

$$
B=\mathrm{R}_{a}-
$$

As whole-body $\mathrm{Rd}$ comprise the rate of phenylalanine disappearance from the free amino acid pool in the blood due to protein synthesis (S) and oxidation, wholebody protein synthesis can be calculated as $\mathrm{Rd}$ minus oxidation. The rate of phenylalanine oxidation was calculated using the phenylalanine balance model from Thompson et al. (42). Whole-body phenylalanine oxidation (Qpt) can be determined from the conversion (hydroxylation) of L-[ring- $\left.{ }^{13} \mathrm{C}_{6}\right]$ phenylalanine to L-[ring- $\left.{ }^{13} \mathrm{C}_{6}\right]$ tyrosine, without the necessity to measure ${ }^{13} \mathrm{CO}_{2}$ enrichment in breath gasses (42). The rate of hydroxylation can be calculated using the formula,

$$
Q_{p t}=\frac{P_{t}}{P_{p}} \cdot\left(\frac{Q p^{2}}{\left(\frac{E_{p}}{E_{t}}-1\right)} \overline{\boldsymbol{F}-? p_{-}^{-}}\right.
$$

where $\mathrm{Pt} / \mathrm{Pp}(=0.73)$ is the molar ratio of fluxes of tyrosine and phenylalanine arising form protein catabolism (31); Qp equals $\mathrm{Rd}$ under the steady state conditions that we observed. Ep and Et are the L-[ring- ${ }^{13} \mathrm{C}_{6}$ ]phenylalanine and L[ring- ${ }^{13} \mathrm{C}_{6}$ ] tyrosine enrichments (expressed in Atom Percent Excess; APE). Wholebody protein synthesis was calculated using

$$
S=\gtrless_{d}-?_{p t}
$$

Fractional rate of mixed muscle protein synthesis was calculated by dividing the increment in enrichment in the product, i.e. protein-bound L-[ring${ }^{13} \mathrm{C}_{6}$ ]phenylalanine (TTR), by the enrichment of the precursor. Due to the large muscle sample size that is required to make an estimate of the enrichment in the aminoacyl-tRNA pool (generally regarded to be the true protein synthesis precursor pool) and the inherent analytical complexity of such measurements, we used plasma L-[ring- ${ }^{13} \mathrm{C}_{6}$ ]phenylalanine $\left(\mathrm{T}^{6} \mathrm{TR}\right)$ and free muscle L-[ring- $\left.{ }^{13} \mathrm{C}_{6}\right]$ phenylalanine (TTR) enrichments as surrogates to provide an estimate of the lower boundary (based on plasma precursor enrichments) and the higher boundary 
(based on intracellular muscle precursor enrichments) for the true fractional synthetic rate of mixed muscle proteins. Muscle FSR's were calculated as follows,

$$
F S R=\frac{\Delta E p \cdot 2}{E_{\text {precursor }} \cdot t} \cdot 100
$$

where $\Delta \mathrm{Ep}$ is the delta increment of protein bound L-[ring- $\left.{ }^{13} \mathrm{C}_{6}\right]$ phenylalanine during incorporation periods. Eprecursor is (I) the average plasma L-[ring${ }^{13} \mathrm{C}_{6}$ ]phenylalanine enrichment during the time period for determination of amino acid incorporation; (II) the free muscle L-[ring- $\left.{ }^{13} \mathrm{C}_{6}\right]$ phenylalanine enrichment in muscle biopsy taken at $6 \mathrm{~h}$ post-exercise; (III) the free muscle L-[ring$\left.{ }^{13} \mathrm{C}_{6}\right]$ phenylalanine enrichment in muscle biopsy taken at $6 \mathrm{~h}$ post-exercise corrected for the contribution of extra-cellular water, as previously described (50). $t$ indicates the time interval $(\mathrm{h})$ between biopsies and the factor 100 is needed to express the FSR in percent per hour $\left(\% \cdot \mathrm{h}^{-1}\right)$. The factor 2 arises because in the NAM-ester of L-[ring- $\left.{ }^{13} \mathrm{C}_{6}\right]$ phenylalanine molecule six of a total of twelve carbon atoms are labeled.

\section{Statistics}

All data are expressed as means \pm SEM. The plasma essential amino acid, insulin and glucose responses were calculated as area under the curve above pre-drink values. Statistical analysis of the data was performed using a one factor repeated measures analysis of variance (ANOVA) for non-time dependent variables. A twofactor repeated measures ANOVA with time and treatment as factors was used to compare differences between treatments over time. In case of significant difference between trials, a Tukey's post hoc test was applied to locate these differences. Statistical significance was set at $\mathrm{P}<0.05$.

\section{Results}

Plasma insulin levels increased in all trials during the first 15-30 min after initial beverage ingestion. After this strong initial increase, insulin concentrations plateaued after 3-4h of recovery. Plasma insulin concentrations in the $\mathrm{CHO}+\mathrm{PRO}$ and $\mathrm{CHO}+\mathrm{PRO}+$ leu trials increased more compared to the $\mathrm{CHO}$ trial (figure 5.1A). The insulin response, expressed as area under the curve (above baseline values) during the entire $6 \mathrm{~h}$ post-exercise period (figure $5.1 \mathrm{~B}$ ), was substantially greater in the $\mathrm{CHO}+\mathrm{PRO}+$ leu trial compared to the $\mathrm{CHO}$ and $\mathrm{CHO}+\mathrm{PRO}$ trials (12.6 \pm 1.2 vs. $3.7 \pm 0.4$ and $7.4 \pm 0.9 \mathrm{U} \cdot 6 \mathrm{~h} \cdot \mathrm{L}^{-1}$, respectively; $\mathrm{P}<0.01$, which represent a $+240 \pm 19$ and $+77 \pm 11 \%$ increase, respectively). The observed insulin response during the recovery period in $\mathrm{CHO}+\mathrm{PRO}$ trial was increased with $+98 \pm 17 \%$ compared to the $\mathrm{CHO}$ trial $(\mathrm{P}<0.05)$. Plasma glucose levels significantly increased following administration of the first beverage, after which they tended to decrease. The glucose response, expressed as area under the curve above baseline values, was significantly lower in the $\mathrm{CHO}+\mathrm{PRO}+$ leu trial compared with the $\mathrm{CHO}$ trial 
(96 \pm 62 vs. $\left.320 \pm 65 \mathrm{mmol} \cdot 6 \mathrm{~h} \cdot \mathrm{L}^{-1}, \mathrm{P}<0.05\right)$, with an intermediate value for the $\mathrm{CHO}+\mathrm{PRO}$ trial $\left(216 \pm 48 \mathrm{mmol} \cdot 6 \mathrm{~h} \cdot \mathrm{L}^{-1}\right)$.
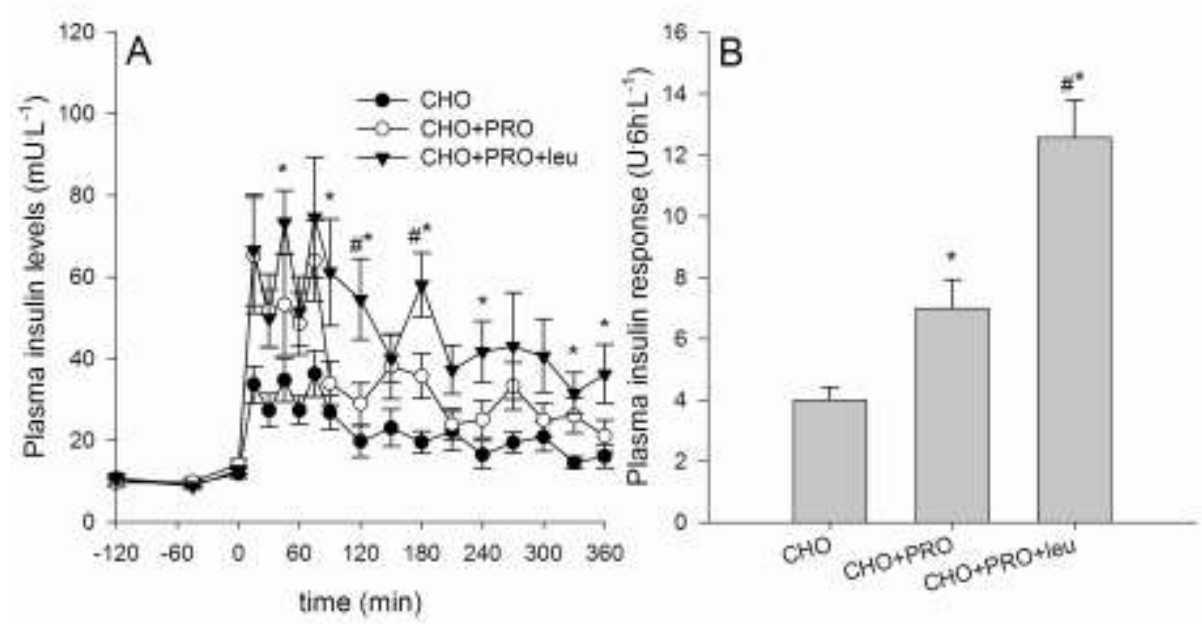

Figure 5.1 A, Plasma insulin concentration (expressed in $\mathrm{mU} \cdot \mathrm{L}^{-1}$ ); B, plasma insulin response (expressed as area

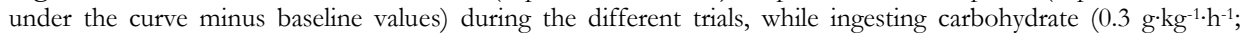

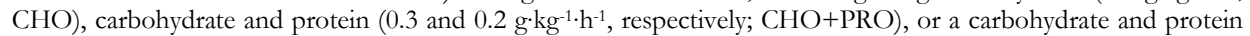

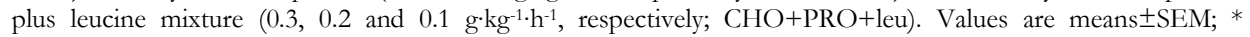
significantly different from $\mathrm{CHO}$; \# significantly different from $\mathrm{CHO}+\mathrm{PRO}$.

Plasma leucine, phenylalanine and tyrosine concentrations are reported in figure 5.2. Plasma essential amino acid (EAA) responses (area under the curve above baseline) are reported in figure 5.3. Resting plasma phenylalanine concentration averaged 53.6 $\pm 1.4 \mu \mathrm{mol} \cdot \mathrm{L}^{-1}$. After ingestion of the first bolus plasma phenylalanine concentrations increased in the $\mathrm{CHO}+\mathrm{PRO}$ and $\mathrm{CHO}+\mathrm{PRO}+$ leu trials $(\mathrm{P}<0.05)$, whereas a slight non-significant decrease was observed in the $\mathrm{CHO}$ trial during the first $2 \mathrm{~h}$ of post-exercise recovery (figure 5.2B).

The plasma phenylalanine response (figure 5.3) was negative in the CHO trial, whereas it was positive in the $\mathrm{CHO}+\mathrm{PRO}$ and $\mathrm{CHO}+\mathrm{PRO}+$ leu trials $(-2.92 \pm 1.00$ vs. $3.25 \pm 0.72$ and $1.47 \pm 0.81 \mathrm{mmol} \cdot 6 \mathrm{~h} \cdot \mathrm{L}^{-1}$, respectively; $\left.\mathrm{P}<0.01\right)$. Plasma leucine concentrations (figure $5.2 \mathrm{~A}$ ) strongly increased after ingestion of the first bolus $(\mathrm{P}<0.01)$ in the $\mathrm{CHO}+\mathrm{PRO}+\mathrm{leu}$ and $\mathrm{CHO}+\mathrm{PRO}$ trials whereas a slight decrease $(\mathrm{P}<0.05)$ was observed in the $\mathrm{CHO}$ trial during the first $2 \mathrm{~h}$ of recovery. The plasma leucine response (figure 5.3) was negative in the $\mathrm{CHO}$ trial, positive in the $\mathrm{CHO}+\mathrm{PRO}$ trial and significantly higher in the $\mathrm{CHO}+\mathrm{PRO}+\mathrm{leu}$ trial compared to both other trials $\left(-9 \pm 5,46 \pm 12\right.$ and $468 \pm 62 \mathrm{mmol} \cdot 6 \mathrm{~h} \cdot \mathrm{L}^{-1}$, respectively; $\left.\mathrm{P}<0.05\right)$. The observed plasma insulin response was strongly correlated with the observed plasma leucine concentration $(\mathrm{r}=0.77 ; \mathrm{P}<0.001)$. Basal plasma tyrosine concentrations averaged $65.3 \pm 0.8 \mu \mathrm{mol} \cdot \mathrm{L}^{-1}$ in all trials. Plasma tyrosine concentrations increased after ingestion of the first bolus in the $\mathrm{CHO}+\mathrm{PRO}$ and $\mathrm{CHO}+\mathrm{PRO}+$ leu trials 
$(\mathrm{P}<0.05)$. In the $\mathrm{CHO}$ trial the concentration decreased $(\mathrm{P}<0.05)$ during the first $2 \mathrm{~h}$ after exercise (figure 5.2C). Whereas plasma tyrosine responses were negative in the $\mathrm{CHO}$ trial, they were positive in the $\mathrm{CHO}+\mathrm{PRO}$ and $\mathrm{CHO}+\mathrm{PRO}+$ leu trials ($5.0 \pm 1.5$ vs. $11.2 \pm 2.3$ and $4.3 \pm 0.8 \mathrm{mmol} \cdot 6 \mathrm{~h} \cdot \mathrm{L}^{-1}$, respectively; $\left.\mathrm{P}<0.01\right)$.
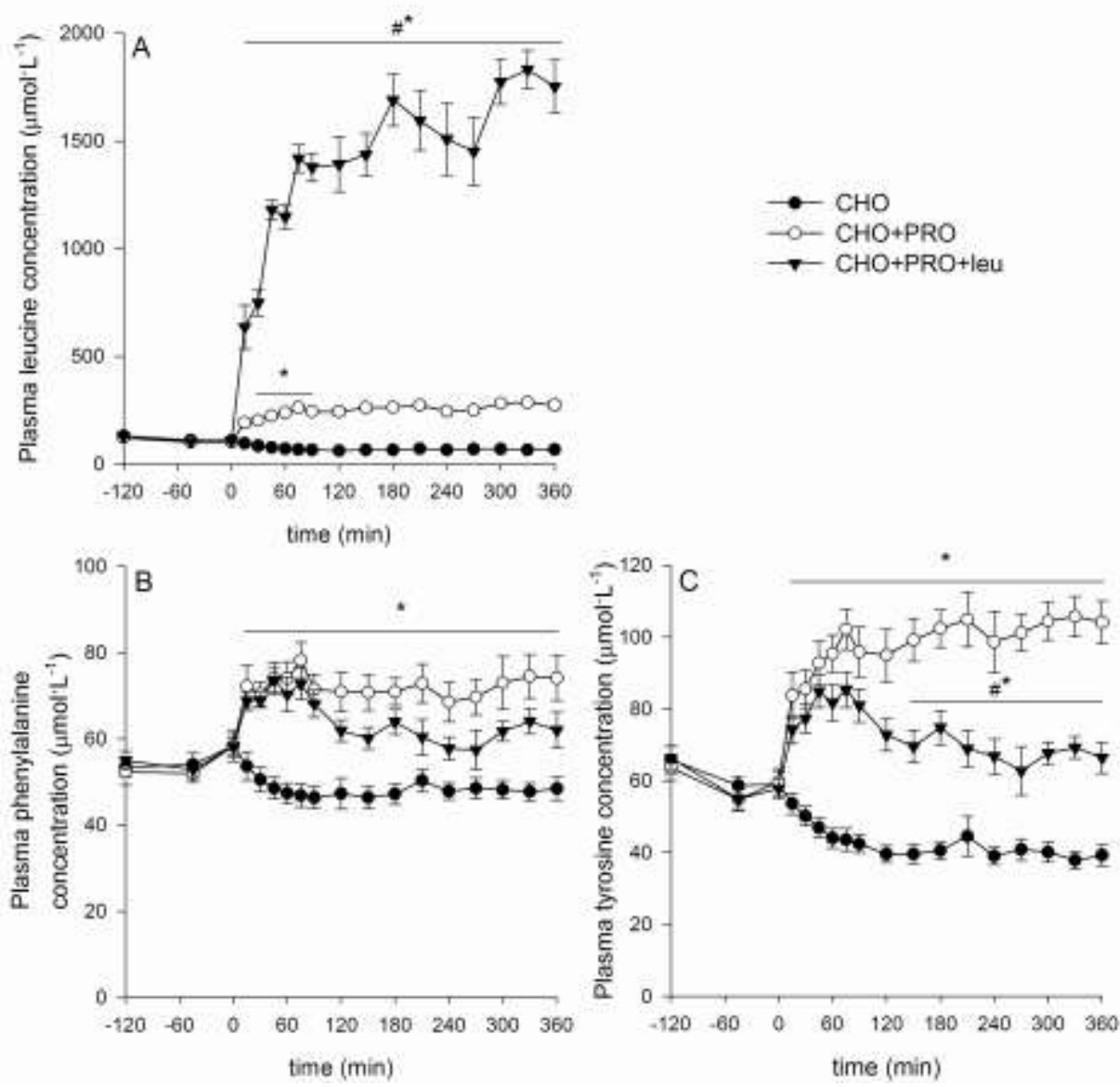

Figure 5.2 Plasma leucine (A); phenylalanine (B); plasma tyrosine $(\mathrm{C})$ concentration $\left(\mu \mathrm{mol} \cdot \mathrm{L}^{-1}\right)$, during the $\mathrm{CHO}$, $\mathrm{CHO}+\mathrm{PRO}$ and $\mathrm{CHO}+\mathrm{PRO}+$ leu trials. Values are means \pm SEM. * significantly different from $\mathrm{CHO}$; \# significantly different from $\mathrm{CHO}+\mathrm{PRO}$.

The time course of the plasma L-[ring- $\left.{ }^{13} \mathrm{C}_{6}\right]$ phenylalanine and L-[ring- $\left.{ }^{13} \mathrm{C}_{6}\right]$ tyrosine enrichments are shown in figure 5.4. Plasma L-[ring- $\left.{ }^{13} \mathrm{C}_{6}\right]$ phenylalanine enrichment increased after exercise in the $\mathrm{CHO}$ trial. In the $\mathrm{CHO}+\mathrm{PRO}$ and $\mathrm{CHO}+\mathrm{PRO}+$ leu trials, plasma $\mathrm{L}-\left[\right.$ ring $\left.-{ }^{13} \mathrm{C}_{6}\right]$ phenylalanine enrichment slightly decreased to reach plateau values at $\mathrm{t}=60 \mathrm{~min}$. Plasma $\mathrm{L}$-[ring $\left.{ }^{13} \mathrm{C}_{6}\right]$ phenylalanine enrichment was significantly greater in the $\mathrm{CHO}$ trial compared to the $\mathrm{CHO}+\mathrm{PRO}$ and $\mathrm{CHO}+\mathrm{PRO}+$ leu trials $(\mathrm{P}<0.05)$. Plasma $\mathrm{L}-\left[\right.$ ring- ${ }^{13} \mathrm{C}_{6}$ ] tyrosine enrichment 
increased after exercise in the $\mathrm{CHO}$ trial, but remained unchanged in the $\mathrm{CHO}+\mathrm{PRO}$ and $\mathrm{CHO}+\mathrm{PRO}+$ leu trials. Plasma L-[ring- $\left.{ }^{13} \mathrm{C}_{6}\right]$ tyrosine enrichment was significantly higher in the $\mathrm{CHO}$ compared to the $\mathrm{CHO}+\mathrm{PRO}$ and $\mathrm{CHO}+\mathrm{PRO}+$ leu trials $(\mathrm{P}<0.05)$. Mean plasma amino acid enrichment, plasma phenylalanine rate of appearance $(\mathrm{Ra})$ and rate of disappearance $(\mathrm{Rd})$, muscle free amino acid enrichment and the increment in muscle protein enrichment are presented in table 5.2.

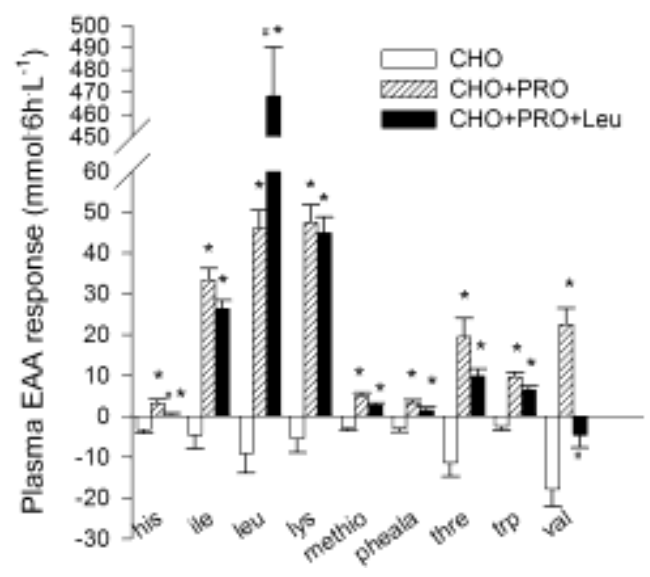

Figure 5.3 Plasma essential amino acid response (expressed as area under the curve minus baseline values) during the $\mathrm{CHO}, \mathrm{CHO}+\mathrm{PRO}$ and $\mathrm{CHO}+\mathrm{PRO}+$ leu trials. Values are means $\pm \mathrm{SEM}$; * significantly different from $\mathrm{CHO}$; \# significantly different from $\mathrm{CHO}+\mathrm{PRO}$.
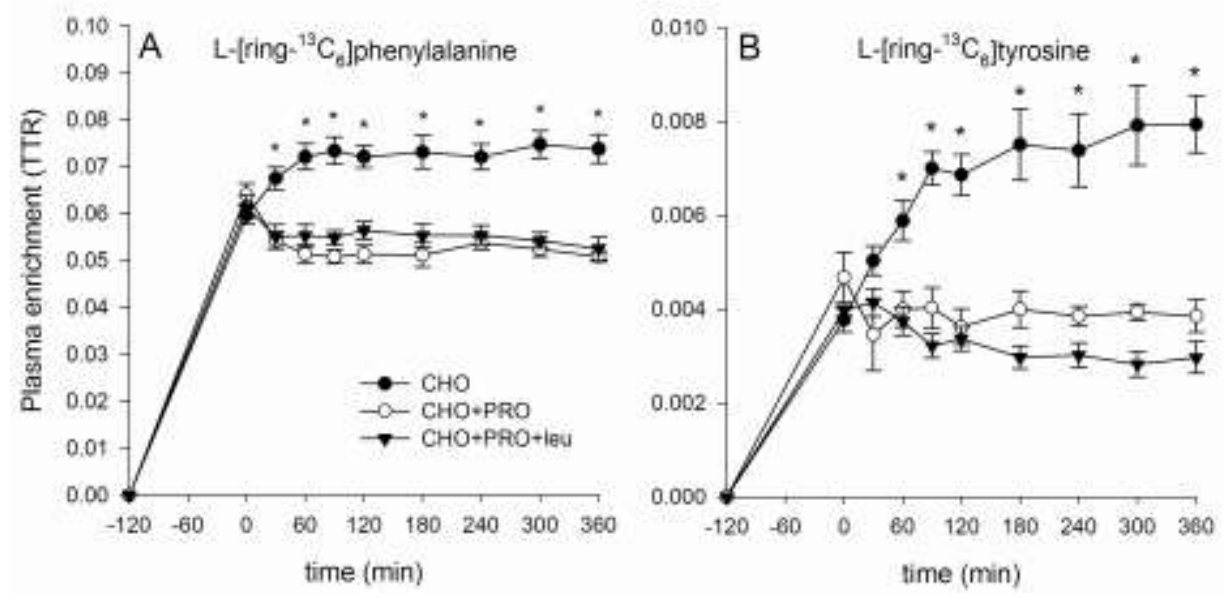

Figure 5.4 Plasma L-[ring- $\left.{ }^{13} \mathrm{C}_{6}\right]$ phenylalanine enrichment $(\mathrm{A})$ and plasma L-[ring- $\left.{ }^{13} \mathrm{C}_{6}\right]$ tyrosine enrichment $(\mathrm{B})$ during the $\mathrm{CHO}, \mathrm{CHO}+\mathrm{PRO}$ and $\mathrm{CHO}+\mathrm{PRO}+$ leu trials. Values are means $\pm \mathrm{SEM}$; $*$ significantly different from $\mathrm{CHO}+\mathrm{PRO}$ and $\mathrm{CHO}+\mathrm{PRO}+$ leu. 
Whole-body protein breakdown (figure 5.5), calculated over the $6 \mathrm{~h}$ of postexercise recovery, was lower in the $\mathrm{CHO}+\mathrm{PRO}$ and $\mathrm{CHO}+\mathrm{PRO}+$ leu trials compared to the $\mathrm{CHO}$ trial $(\mathrm{P}<0.05)$. Whole-body protein synthesis (figure 5.5), as calculated by $\mathrm{Rd}-\mathrm{Rox}$, was increased in the $\mathrm{CHO}+\mathrm{PRO}$ and $\mathrm{CHO}+\mathrm{PRO}+\mathrm{leu}$ trial compared to the $\mathrm{CHO}$ trial $(\mathrm{P}<0.05)$. The rate of post-exercise whole-body phenylalanine oxidation (figure 5.5), as calculated from the conversion of phenylalanine to tyrosine, was decreased in the $\mathrm{CHO}+\mathrm{PRO}+$ leu trial compared to the $\mathrm{CHO}+\mathrm{PRO}$ and $\mathrm{CHO}$ trials $(\mathrm{P}<0.05)$. Whole-body protein balance (figure 5.5) was negative in the $\mathrm{CHO}$ trial, whereas protein balance was positive in the $\mathrm{CHO}+\mathrm{PRO}$ and $\mathrm{CHO}+\mathrm{PRO}+$ leu trials. In addition, whole-body protein balance was higher in $\mathrm{CHO}+\mathrm{PRO}+$ leu than in $\mathrm{CHO}+\mathrm{PRO}(\mathrm{P}<0.01)$. Whole-body protein breakdown correlated with the plasma insulin and leucine responses $(\mathrm{r}=-0.670$ and $\mathrm{r}=-0.647$, respectively; $\mathrm{P}<0.01$ ). Whole-body net protein balance was positively correlated with the plasma insulin and leucine response $(r=0.678$ and $r=0.626$, respectively; $\mathrm{P}<0.01)$.

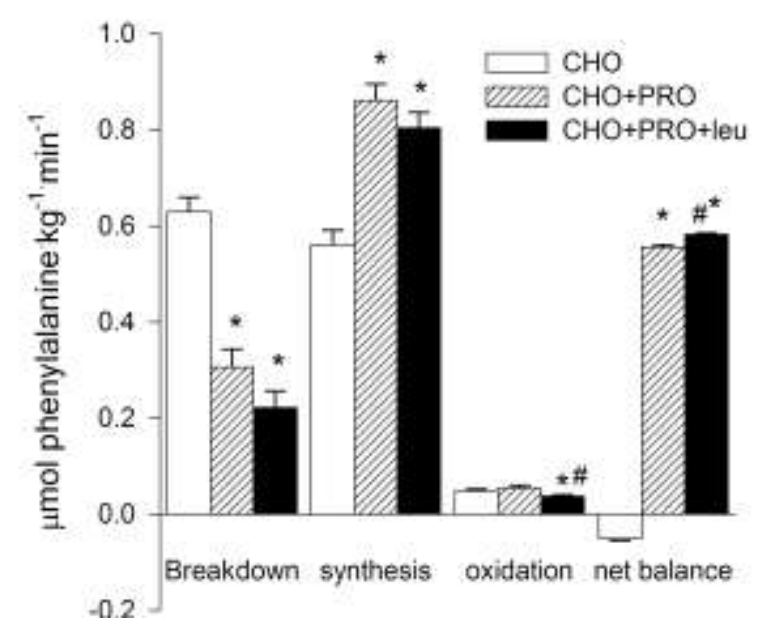

Figure 5.5 The rate of whole-body protein breakdown, synthesis, oxidation and net balance (expressed as $\mu \mathrm{mol}$ phenylalanine.kg.min-1) during the $\mathrm{CHO}, \mathrm{CHO}+\mathrm{PRO}$ and $\mathrm{CHO}+\mathrm{PRO}+$ leu trials. Values are means $+\mathrm{SEM}$; $*$ significantly different from $\mathrm{CHO}$; \# significantly different from $\mathrm{CHO}+\mathrm{PRO}$.

Mixed muscle protein fractional synthesis rates (FSR) were calculated using the precursor-product equation outlined in the methods section. FSR, with the mean plasma L-[ring- ${ }^{13} \mathrm{C}_{6}$ ] phenylalanine enrichment as precursor (figure 5.6), was significantly higher in the $\mathrm{CHO}+\mathrm{PRO}+$ leu trial compared to the $\mathrm{CHO}$ trial $\left(0.095 \pm 0.005\right.$ vs. $0.061 \pm 0.009 \% \cdot \mathrm{h}^{-1}$, respectively; $\left.\mathrm{P}<0.05\right)$, with intermediate values observed in the $\mathrm{CHO}+\mathrm{PRO}$ trial $\left(0.0820 \pm 0.0104 \% \cdot \mathrm{h}^{-1}\right)$. When the free intracellular L-[ring- $\left.{ }^{13} \mathrm{C}_{6}\right]$ phenylalanine enrichment was used as the precursor, FSR values were higher then when calculated with plasma $\mathrm{L}-\left[\mathrm{ring}{ }^{13} \mathrm{C}_{6}\right]$ phenylalanine enrichment as precursor, but revealed the same intervention effect $(\mathrm{P}=0.052)$. FSR 
values averaged $0.089 \pm 0.012,0.110 \pm 0.013$, and $0.128 \pm 0.007 \% \cdot \mathrm{h}^{-1}$ for the $\mathrm{CHO}$, $\mathrm{CHO}+\mathrm{PRO}$ and $\mathrm{CHO}+\mathrm{PRO}+$ leu trial, respectively. When these values were corrected for the contribution of extracellular water to the measured free muscle L-[ring- ${ }^{13} \mathrm{C}_{6}$ ] phenylalanine enrichment (50), FSR values averaged $0.097 \pm 0.013$, $0.117 \pm 0.014$, and $0.136 \pm 0.007 \% \cdot \mathrm{h}^{-1}$ for the $\mathrm{CHO}, \mathrm{CHO}+\mathrm{PRO}$ and $\mathrm{CHO}+\mathrm{PRO}+$ leu trial, respectively, with the same intervention effect $(\mathrm{P}=0.073)$. Significant correlations were observed between FSR and the amount of leucine ingested ( $\mathrm{r}=0.471 ; \mathrm{P}<0.05)$, phenylalanine $\mathrm{Rd}(\mathrm{r}=0.531 ; \mathrm{P}<0.01)$, whole-body protein synthesis $(\mathrm{r}=0.548 ; \mathrm{P}<0.01)$, and whole-body protein balance $(\mathrm{r}=0.507$; $\mathrm{P}<0.02)$.

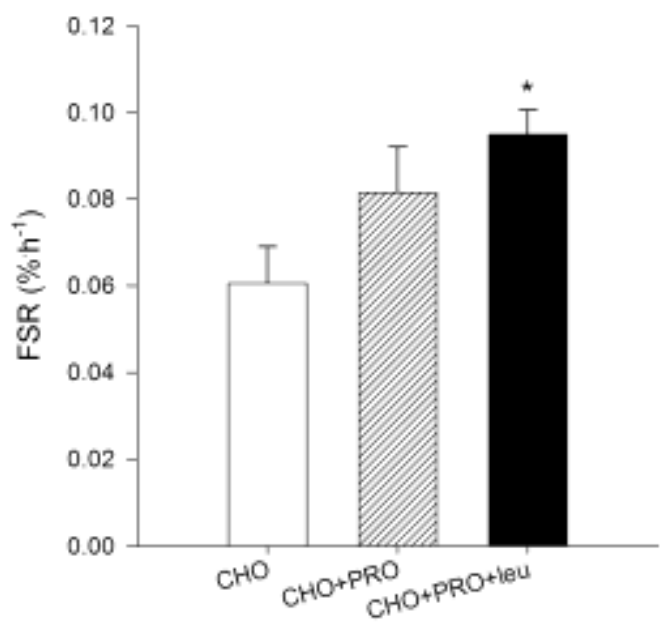

Figure 5.6 Fractional synthetic rate (FSR) of mixed muscle protein during the recovery phase from resistance exercise during the $\mathrm{CHO}, \mathrm{CHO}+\mathrm{PRO}$ and $\mathrm{CHO}+\mathrm{PRO}+$ leu trials. Values are means $\pm \mathrm{SEM}$; $*$ significantly different from $\mathrm{CHO}$.

\section{Discussion}

In the present study we simultaneously assessed whole-body protein turnover as well as the fractional synthetic rate (FSR) of mixed muscle protein by the incorporation of labeled phenylalanine in the $\mathrm{m}$. vastus lateralis after resistance exercise. The co-ingestion of leucine and protein with carbohydrate significantly increased whole-body net protein balance compared to carbohydrate intake only and the combined ingestion of carbohydrate and protein. In addition, muscle protein synthesis rates were higher when protein and free leucine were co-ingested compared to the ingestion of carbohydrate only. Ingestion of carbohydrate and protein resulted in intermediate muscle protein synthesis rates, which were not significantly different from rates observed after co-ingestion of protein and leucine and carbohydrate ingestion only. Thus, the present study shows that the combined ingestion of protein and leucine with carbohydrate stimulates protein anabolism, measured using both tracer incorporation and whole-body tracer methodology. 
It has been shown that both muscle protein synthesis $(7,35,44)$ as well as protein breakdown rates $(7,35)$ are accelerated following resistance exercise. Resistance exercise exerts its effect either via the increased local production of IGF-1 in the muscle (21) and/or other contraction induced signaling events. Although muscle protein synthesis is stimulated during the post-exercise recovery phase (35), net muscle protein balance remains negative in the absence of food intake $(7,35,36)$. It has been shown that the administration of amino acids with or without carbohydrate results in a rapid increase in muscle protein synthesis rate, whereas protein degradation rate is decreased $(8,11,39,44,45)$. This results in an improved (positive) net muscle protein balance at rest and/or during post-exercise recovery.

The combined intake of free leucine and protein with carbohydrate has been shown to increase the plasma insulin response (47-49). Increased amounts of circulating insulin have been reported to increase net muscle protein balance during conditions of hyperaminoacidemia $(18,19,22)$, which occurs primarily by inhibition of muscle protein breakdown, rather than by stimulating protein synthesis. Furthermore, leucine ingestion has been reported to stimulate muscle protein synthesis, independent of circulating plasma insulin levels, by increasing the phosphorylation (activation) of key proteins involved in the regulation of protein synthesis in rat $(1,4)$ and human skeletal muscle $(23,28)$. An insulinotropic mixture containing carbohydrate, protein and leucine could therefore likely represent an efficient nutritional intervention to optimize net muscle accretion during post-exercise recovery.

Using whole-body tracer balance methodology we observed that protein breakdown rates exceeded protein synthesis rates in the $\mathrm{CHO}$ trial, leading to a negative net protein balance (figure 5.5). The latter is in line with data from Borsheim et al. (2004) who showed that protein balance over the (leg) muscle remains negative after resistance exercise when only carbohydrate is ingested (10). However, measurements over the muscle do not necessarily account for all of the changes observed on a whole-body level. Whole-body protein breakdown rates were significantly suppressed in the $\mathrm{CHO}+\mathrm{PRO}$ and $\mathrm{CHO}+\mathrm{PRO}+\mathrm{leu}$ trials compared to the $\mathrm{CHO}$ trial, whereas protein synthesis rates were increased (figure 5.5). Co-ingestion of protein or protein and leucine with carbohydrate resulted in a $50 \pm 2 \%$ and $62 \pm 2 \%$ reduction in protein degradation, respectively, when compared to carbohydrate ingestion only. In addition, protein synthesis was $54 \pm 5 \%$ and $45 \pm 5 \%$ increased in the $\mathrm{CHO}+\mathrm{PRO}$ and $\mathrm{CHO}+\mathrm{PRO}+$ leu trials, respectively, compared to the $\mathrm{CHO}$ trial. When whole-body protein synthesis rates were expressed as a percentage of the rate of disappearance $(\mathrm{Rd})$ of phenylalanine, we found the highest values in the $\mathrm{CHO}+\mathrm{PRO}+\mathrm{leu}$ trial $(95.6 \pm 0.1 \%$ compared to $92.0 \pm 0.4 \%$ and $94.2 \pm 0.4 \%$ in the $\mathrm{CHO}$ and $\mathrm{CHO}+\mathrm{PRO}$ trials respectively; $\mathrm{P}<0.05$ ), which could be attributed to a decreased rate of phenylalanine oxidation in the $\mathrm{CHO}+\mathrm{PRO}+$ leu compared to the $\mathrm{CHO}+\mathrm{PRO}$ trial, with intermediate values found in the $\mathrm{CHO}$ trial. Such a reduction in amino acid oxidation after administration of leucine has previously been established (32). Our findings are in accordance with earlier reports $(27,30,39)$ showing that the combined ingestion of a single bolus of protein/amino acids and carbohydrate improves protein balance 
in the post-resistance exercise period. In the present study we extend on these findings by investigating whether additional leucine could further promote protein anabolism. Therefore, in both the $\mathrm{CHO}+\mathrm{PRO}$ and $\mathrm{CHO}+\mathrm{PRO}+$ leu trials we provided an ample supply of protein $\left(0.2 \mathrm{~g}^{\mathrm{kg}} \mathrm{gg}^{-1} \mathrm{~h}-1\right)$. This amount by far exceeds the amount of protein that was estimated to allow sustained maximal protein synthesis rates (50), and was selected to ensure that precursor substrate availability would not be limiting. Repeated boluses were administered, as opposed to a single bolus approach, to ensure a continuous supply of amino acids. Consequently, we show that the co-ingestion of leucine even further increases the net protein balance compared to carbohydrate and protein ingestion (figure 5.5).

Most studies have applied the (whole-body) tracer balance methodology to investigate the effect of post-exercise nutrition on protein metabolism. Unfortunately, whole-body tracer methods have some important limitations, as they do not allow the direct measurement of muscle protein synthesis rates. As such, they do not provide information on the contribution of individual tissues to protein metabolism, their response to nutritional and/or exercise intervention and do not enable the discrimination between active and inactive muscle. Therefore, we also measured the incorporation rate of labeled phenylalanine in skeletal muscle tissue after resistance exercise to determine FSR of mixed muscle protein in the active $\mathrm{m}$. vastus lateralis. We used plasma $\mathrm{L}$-[ring $\left.-{ }^{13} \mathrm{C}_{6}\right]$ phenylalanine and free muscle L-[ring- $\left.{ }^{13} \mathrm{C}_{6}\right]$ phenylalanine enrichments to provide an estimate of the lower boundary (based on plasma precursor enrichments) and the higher boundary (based on intracellular muscle precursor enrichments) for the true fractional synthetic rate of mixed muscle proteins. Both methods provided similar results. As we observed a higher variation in intracellular muscle precursor enrichment, we based the FSR values on plasma precursor enrichments. Mixed muscle FSR averaged $0.0605 \pm 0.0085 \% \cdot \mathrm{h}^{-1}$ during $6 \mathrm{~h}$ of post-exercise recovery while ingesting carbohydrate. Combined ingestion of leucine and protein with carbohydrate resulted in a significantly increased FSR compared to carbohydrate ingestion alone (figure 5.6). The combined ingestion of protein and carbohydrate without free leucine resulted in an intermediate value, and was not significantly different from the lower values in the $\mathrm{CHO}$ trial nor the higher values reported in the $\mathrm{CHO}+\mathrm{PRO}+$ leu trials (figure 5.6). Therefore our data on the muscle level also show that the combined ingestion of leucine and protein with carbohydrate can effectively stimulate muscle protein synthesis.

The presented FSR data are in line with our observations using whole-body tracer methods, showing that co-ingestion of leucine and protein with carbohydrate accelerates protein synthesis and improves net protein balance when compared to carbohydrate ingestion only. Using whole-body tracer methodology, our data indicate that the combined ingestion of leucine and protein with carbohydrate can reduce protein breakdown. The latter seems to be in line with earlier reports by Nair et al (1992), who showed that leucine infusion significantly decreases protein breakdown as well as amino acid oxidation rate. In addition, data from the same study showed a decrease in the plasma concentrations of the other essential amino acids (EAA) during leucine infusion. In the present study we also observed a 
reduced plasma EAA response in the $\mathrm{CHO}+\mathrm{PRO}+$ leu trial compared to the $\mathrm{CHO}+\mathrm{PRO}$ trial, although the same amount of EAA (with the exclusion of the supplemented leucine) was consumed. However, no differences were observed in phenylalanine $\mathrm{Rd}$ between the $\mathrm{CHO}+\mathrm{PRO}+\mathrm{leu}$ and $\mathrm{CHO}+\mathrm{PRO}$ trials. This diminished plasma EAA response following leucine supplementation could be attributed to a reduced release from the muscle, and indicating a reduced protein breakdown and/or reduced protein oxidation rate (figure 5.5).

We recently reported that co-ingestion of leucine, phenylalanine and protein with carbohydrate results in an increased plasma insulin response in the post-absorptive resting state $(46,49)$ and during recovery from endurance exercise $(47,48)$. In the present study we demonstrate that combined ingestion of leucine and protein with carbohydrate (without phenylalanine) can substantially increase the insulin response by $\sim 250 \%$ when compared to the ingestion of only carbohydrate. Circulating insulin concentrations play an important role in regulating protein metabolism. The mechanism by which insulin mediates muscle hypertrophy is still a subject of debate as some reports $(9,18,19)$ indicate that insulin infusion reduces protein breakdown while others $(6,20)$ have reported an enhanced muscle protein synthesis rate when sufficient amino acids were made available. However, in the absence of an ample supply of amino acids, insulin does not seem to stimulate muscle protein synthesis (9). In the present study, we found plasma insulin responses to be negatively correlated with whole-body protein degradation $(\mathrm{r}=-$ $0.641 ; \mathrm{P}<0.01)$, whereas whole-body protein synthesis was positively correlated with plasma insulin response $(\mathrm{r}=0.451 ; \mathrm{P}<0.05)$. Muscle protein synthesis rates (FSR) did not correlate with the plasma insulin response, whereas mixed muscle protein FSR did correlate with the amount of leucine that was ingested $(\mathrm{r}=0.471$; $\mathrm{P}<0.05)$. Whether the observed differences can be attributed to the insulin or noninsulin dependent stimulatory effects of leucine remains to be established.

The combined ingestion of leucine and protein with carbohydrate in the recovery period from resistance exercise could stimulate muscle protein synthesis in several ways. It provides amino acids as precursors for muscle protein synthesis and the added leucine further increases plasma insulin concentrations and could also directly stimulate protein synthesis. Leucine has been shown to have the potential to affect muscle protein metabolism by decreasing the rate of protein degradation (32), most likely via increases in circulating insulin, and the phosphorylation of key proteins involved in the regulation of protein synthesis $(23,28,37)$. The latter has been shown to occur even in the absence of an increase in circulating insulin concentrations. These studies indicate that leucine has the ability to function as a nutritional signaling molecule that modulates muscle protein synthesis and/or breakdown following food intake. The stimulatory effect of leucine on protein synthesis occurs at the level of translation initiation and involves signaling through mTOR $(24,37)$. This protein kinase referred to as mammalian target of rapamycin is thought to serve as a convergence point for leucine- and insulin-mediated effects on translation initiation $(24,37)$. Maximal rates of protein synthesis rates probably require both leucine and insulin signaling and the anabolic signal of resistance exercise. However, under normal in vivo conditions it is impossible to discriminate 
between the effects of leucine and insulin and resistance exercise (IGF-1 and MGF) on muscle protein synthesis as all these signals are substantially elevated in the $\mathrm{CHO}+\mathrm{PRO}+$ leu trial.

In conclusion, the combined ingestion of protein and leucine with carbohydrate improves whole-body protein balance during recovery from resistance exercise when compared to the ingestion of carbohydrate or carbohydrate with protein. The combined ingestion of both leucine and protein with carbohydrate augments post-exercise mixed muscle protein synthesis when compared to the ingestion of only carbohydrate. The present data indicate that the additional ingestion of free leucine in combination with protein and carbohydrate likely represents an effective strategy to increase muscle anabolism following resistance exercise.

\section{Acknowledgements}

We gratefully acknowledge the expert technical assistance of Annemie Gijsen, Annita Rousseau and Jos Stegen and the enthusiastic support of the subjects who volunteered to participate in these trials. This work was partly supported by a grant from Numico Research. 


\section{References}

1. Anthony JC, Anthony TG, Kimball SR, Vary TC, and Jefferson LS. Orally administered leucine stimulates protein synthesis in skeletal muscle of postabsorptive rats in association with increased eIF4F formation. J Nutr 130: 139-145, 2000.

2. Anthony JC, Anthony TG, and Layman DK. Leucine supplementation enhances skeletal muscle recovery in rats following exercise. J Nutr 129: 1102-1106, 1999.

3. Anthony JC, Lang CH, Crozier SJ, Anthony TG, MacLean DA, Kimball SR, and Jefferson LS. Contribution of insulin to the translational control of protein synthesis in skeletal muscle by leucine. Am J Physiol Endocrinol Metab 282: E1092-E1101, 2002.

4. Anthony JC, Reiter AK, Anthony TG, Crozier SJ, Lang CH, MacLean DA, Kimball SR, and Jefferson LS. Orally Administered Leucine Enhances Protein Synthesis in Skeletal Muscle of Diabetic Rats in the Absence of Increases in 4E-BP1 or S6K1 Phosphorylation. Diabetes 51: 928-936, 2002.

5. Bergstrom J, 0036-5513, Article J, and Review. Percutaneous needle biopsy of skeletal muscle in physiological and clinical research. Scand J Clin Lab Invest 35: 609-616, 1975.

6. Biolo G, Declan Fleming RY, and Wolfe RR. Physiologic hyperinsulinemia stimulates protein synthesis and enhances transport of selected amino acids in human skeletal muscle. J Clin Invest 95: 811-819, 1995.

7. Biolo G, Maggi SP, Williams BD, Tipton KD, and Wolfe RR. Increased rates of muscle protein turnover and amino acid transport after resistance exercise in humans. Am J Physiol 268: E514-520, 1995.

8. Biolo G, Tipton KD, Klein S, and Wolfe RR. An abundant supply of amino acids enhances the metabolic effect of exercise on muscle protein. Am J Physiol 273: E122129, 1997.

9. Biolo G, Williams BD, Fleming RY, and Wolfe RR. Insulin action on muscle protein kinetics and amino acid transport during recovery after resistance exercise. Diabetes 48: 949-957, 1999.

10. Borsheim E, Cree MG, Tipton KD, Elliott TA, Aarsland A, and Wolfe RR. Effect of carbohydrate intake on net muscle protein synthesis during recovery from resistance exercise. J Appl Physiol 96: 674-678, 2004.

11. Borsheim E, Tipton KD, Wolf SE, and Wolfe RR. Essential amino acids and muscle protein recovery from resistance exercise. Am J Physiol Endocrinol Metab 283: E648657, 2002.

12. Chesley A, MacDougall JD, Tarnopolsky MA, Atkinson SA, and Smith K. Changes in human muscle protein synthesis after resistance exercise. J Appl Physiol 73: 1383-1388, 1992.

13. Collin-Vidal C, Cayol M, Obled C, Ziegler F, Bommelaer G, and Beaufrere B. Leucine kinetics are different during feeding with whole protein or oligopeptides. Am J Physiol 267: E907-914, 1994.

14. Engelen MP, Deutz NE, Mostert R, Wouters EF, and Schols AM. Response of wholebody protein and urea turnover to exercise differs between patients with chronic obstructive pulmonary disease with and without emphysema. Am J Clin Nutr 77: 868874, 2003.

15. Fekkes D, van Dalen A, Edelman M, and Voskuilen A. Validation of the determination of amino acids in plasma by high-performance liquid chromatography using automated pre-column derivatization with o-phthaldialdehyde. J Chromatogr B Biomed Appl 669: 177-186, 1995. 
16. Floyd JC, Jr., Fajans SS, Conn JW, Knopf RF, and Rull J. Stimulation of insulin secretion by amino acids. J Clin Invest 45: 1487-1502, 1966.

17. Floyd JC, Jr., Fajans SS, Knopf RF, and Conn JW. Evidence that insulin release is the mechanism for experimentally induced leucine hypoglycemia in man. J Clin Endocrinol Metab 28: 266-276, 1963.

18. Fryburg DA, Jahn LA, Hill SA, Oliveras DM, and Barrett EJ. Insulin and insulin-like growth factor-I enhance human skeletal muscle protein anabolism during hyperaminoacidemia by different mechanisms. J Clin Invest 96: 1722-1729, 1995.

19. Gelfand RA and Barrett EJ. Effect of physiologic hyperinsulinemia on skeletal muscle protein synthesis and breakdown in man. J Clin Invest 80: 1-6, 1987.

20. Gore DC, Wolf SE, Sanford AP, Herndon DN, and Wolfe RR. Extremity hyperinsulinemia stimulates muscle protein synthesis in severely injured patients. Am J Physiol Endocrinol Metab 286: E529-534, 2004.

21. Hameed M, Orrell RW, Cobbold M, Goldspink G, and Harridge SD. Expression of IGF-I splice variants in young and old human skeletal muscle after high resistance exercise. J Physiol 547: 247-254, 2003.

22. Hillier TA, Fryburg DA, Jahn LA, and Barrett EJ. Extreme hyperinsulinemia unmasks insulin's effect to stimulate protein synthesis in the human forearm. Am J Physiol 274: E1067-1074, 1998.

23. Karlsson HK, Nilsson PA, Nilsson J, Chibalin AV, Zierath JR, and Blomstrand E. Branched-Chain Amino Acids Increase p70S6 Kinase Phosphorylation in Human Skeletal Muscle after Resistance Exercise. Am J Physiol Endocrinol Metab 287:1-7, 2004.

24. Kimball SR and Jefferson LS. Regulation of global and specific mRNA translation by oral administration of branched-chain amino acids. Biochem Biophys Res Commun 313: 423-427, 2004.

25. Koopman R, Pannemans DL, Jeukendrup AE, Gijsen A, Senden JMG, Halliday D, Saris WHM, van Loon LJC, and Wagenmakers AJM. The combined ingestion of protein and carbohydrate improves protein balance during ultra endurance exercise. Am J Physiol Endocrinol Metab, 287:E558-65, 2004.

26. Kraemer WJ and Fry AC. Strength Testing; Development and Evaluation of Methodology. In: Physiological Assesment of Human Fitness, edited by Maud PJ and Foster C. Leeds: Human Kinetics, 1995, p. 115-133.

27. Levenhagen DK, Carr C, Carlson MG, Maron DJ, Borel MJ, and Flakoll PJ. Postexercise protein intake enhances whole-body and leg protein accretion in humans. Med Sci Sports Exerc 34: 828-837, 2002.

28. Liu Z, Jahn LA, Long W, Fryburg DA, Wei L, and Barrett EJ. Branched chain amino acids activate messenger ribonucleic acid translation regulatory proteins in human skeletal muscle, and glucocorticoids blunt this action. J Clin Endocrinol Metab 86: 2136-2143, 2001.

29. Mayhew JL, Piper FC, and Ware JS. Anthropometric correlates with strength performance among resistance trained athletes. J Sports Med Phys Fitness 33: 159-165, 1993.

30. Miller SL, Tipton KD, Chinkes DL, Wolf SE, and Wolfe RR. Independent and Combined Effects of Amino Acids and Glucose after Resistance Exercise. Med Sci Sports Exerc 35: 449-455, 2003.

31. Munro HN and Fleck A. Analysis of tissues and body fluids for nitrogenous constituents. In: Mammalian Protein Metabolism, edited by Munro HN. New York: Academic, 1969, p. 423-525. 
32. Nair KS, Schwartz RG, and Welle S. Leucine as a regulator of whole-body and skeletal muscle protein metabolism in humans. Am J Physiol 263: E928-934, 1992.

33. Pacy PJ, Garrow JS, Ford GC, Merritt H, and Halliday D. Influence of amino acid administration on whole-body leucine kinetics and resting metabolic rate in postabsorptive normal subjects. Clin Sci (Lond) 75: 225-231, 1988.

34. Pallotta JA and Kennedy PJ. Response of plasma insulin and growth hormone to carbohydrate and protein feeding. Metabolism 17: 901-908, 1968.

35. Phillips SM, Tipton KD, Aarsland A, Wolf SE, and Wolfe RR. Mixed muscle protein synthesis and breakdown after resistance exercise in humans. Am J Physiol 273: E99107, 1997.

36. Pitkanen HT, Nykanen T, Knuutinen J, Lahti K, Keinanen O, Alen M, Komi PV, and Mero AA. Free amino acid pool and muscle protein balance after resistance exercise. Med Sci Sports Exerc 35: 784-792, 2003.

37. Proud CG. mTOR-mediated regulation of translation factors by amino acids. Biochem Biophys Res Commun 313: 429-436, 2004.

38. Rabinowitz D, Merimee TJ, Maffezzoli R, and Burgess JA. Patterns of hormonal release after glucose, protein, and glucose plus priotein. Lancet 2: 454-456, 1966.

39. Rasmussen BB, Tipton KD, Miller SL, Wolf SE, and Wolfe RR. An oral essential amino acid-carbohydrate supplement enhances muscle protein anabolism after resistance exercise. J Appl Physiol 88: 386-392, 2000.

40. Roy BD, Tarnopolsky MA, MacDougall JD, Fowles J, and Yarasheski KE. Effect of glucose supplement timing on protein metabolism after resistance training. J Appl Physiol 82: 1882-1888, 1997.

41. Steele R. Influences of glucose loading and of injected insulin on hepatic glucose output. Ann New York Acad Sci 82: 420-430, 1959.

42. Thompson GN, Pacy PJ, Merritt H, Ford GC, Read MA, Cheng KN, and Halliday D. Rapid measurement of whole-body and forearm protein turnover using a [2H5]phenylalanine model. Am J Physiol 256: E631-639, 1989.

43. Tipton KD, Borsheim E, Wolf SE, Sanford AP, and Wolfe RR. Acute response of net muscle protein balance reflects 24-h balance after exercise and amino acid ingestion. Am J Physiol Endocrinol Metab 284: E76-89, 2003.

44. Tipton KD, Ferrando AA, Phillips SM, Doyle D, Jr., and Wolfe RR. Post-exercise net protein synthesis in human muscle from orally administered amino acids. Am J Physiol 276: E628-634, 1999.

45. Tipton KD, Rasmussen BB, Miller SL, Wolf SE, Owens-Stovall SK, Petrini BE, and Wolfe RR. Timing of amino acid-carbohydrate ingestion alters anabolic response of muscle to resistance exercise. Am J Physiol Endocrinol Metab 281: E197-206, 2001.

46. van Loon LJ, Kruijshoop M, Menheere PP, Wagenmakers AJ, Saris WH, and Keizer HA. Amino acid ingestion strongly enhances insulin secretion in patients with longterm type 2 diabetes. Diabetes Care 26: 625-630, 2003.

47. van Loon LJ, Kruijshoop M, Verhagen H, Saris WH, and Wagenmakers AJ. Ingestion of protein hydrolysate and amino acid-carbohydrate mixtures increases post-exercise plasma insulin responses in men. J Nutr 130: 2508-2513, 2000.

48. van Loon LJ, Saris WH, Kruijshoop M, and Wagenmakers AJ. Maximizing postexercise muscle glycogen synthesis: carbohydrate supplementation and the application of amino acid or protein hydrolysate mixtures. Am J Clin Nutr 72: 106-111, 2000.

49. van Loon LJ, Saris WH, Verhagen H, and Wagenmakers AJ. Plasma insulin responses after ingestion of different amino acid or protein mixtures with carbohydrate. Am J Clin Nutr 72: 96-105, 2000. 
50. Wagenmakers AJ. Tracers to investigate protein and amino acid metabolism in human subjects. Proc Nutr Soc 58: 987-1000, 1999.

51. Wolfe RR. Radioactive and stable isotope tracers in biomedicine: principles and practice of kinetic analysis. New York: Wiley-Liss, 1992. 



\section{6}

Co-ingestion of protein and leucine stimulates muscle protein synthesis rates to the same extent in young and elderly men

René Koopman, Lex Verdijk, Ralph J.F. Manders, Annemie P. Gijsen, Marchel Gorselink, Evelien Pijpers, Anton J.M. Wagenmakers, and Luc J.C. van Loon

Am J Clin Nutr (submitted, 2005) 


\begin{abstract}
The progressive loss of skeletal muscle mass with aging is attributed to a disruption in the regulation of skeletal muscle protein turnover. We investigated the response to the ingestion of carbohydrate with or without protein and free leucine following simulated activities of daily living (ADL) on whole-body protein balance and mixed muscle protein synthesis rates. Eight elderly (75 \pm 1 y) and eight young $(20 \pm 1$ y) lean men were randomly assigned to 2 cross-over experiments in which they consumed either carbohydrate $(\mathrm{CHO})$ or carbohydrate, protein and free leucine $(\mathrm{CHO}+\mathrm{PRO}+\mathrm{leu})$ after performing $30 \mathrm{~min}$ of standardized ADL activities. Primed, continuous infusions with L-[ring- $\left.{ }^{13} \mathrm{C}_{6}\right]$ phenylalanine and L-[ring${ }^{2} \mathrm{H}_{2}$ ] tyrosine were applied, and blood and muscle samples were collected to assess whole-body protein turnover as well as protein fractional synthetic rate (FSR) in the vastus lateralis muscle over a $6 \mathrm{~h}$ period. Whole-body phenylalanine and tyrosine flux were significantly higher in the young versus the elderly $(\mathrm{P}<0.01)$. Protein balance was negative in the $\mathrm{CHO}$, but positive in the $\mathrm{CHO}+\mathrm{PRO}+$ leu experiment in both groups. Mixed muscle protein synthesis rates (FSR) were significantly lower in the elderly compared with the young subjects $(\mathrm{P}<0.05)$. FSR values were significantly greater in the $\mathrm{CHO}+\mathrm{PRO}+$ leu compared with the $\mathrm{CHO}$ experiment in both the young $\left(0.082 \pm 0.005 \% \cdot \mathrm{h}^{-1}\right.$ vs. $0.060 \pm 0.005 \% \cdot \mathrm{h}^{-1}$, respectively; $\mathrm{P}<0.01)$, and elderly subjects $\left(0.072 \pm 0.006 \% \cdot \mathrm{h}^{-1}\right.$ vs. $0.043 \pm 0.003$ $\% \cdot \mathrm{h}^{-1}$, respectively; $\left.\mathrm{P}<0.01\right)$. Co-ingestion of protein and leucine with carbohydrate following ADL activities improves whole-body protein balance and increases muscle protein synthesis rates to the same extent in lean, young and elderly men.
\end{abstract}




\section{Introduction}

Aging is associated with a slow progressive loss of skeletal muscle mass, which is also called sarcopenia (1). Sarcopenia is generally accompanied by a reduction in strength, the loss of functional capacity and an increased risk of developing chronic metabolic diseases like obesity, type 2 diabetes and osteoporosis. Sarcopenia is facilitated by a combination of factors, which include a sedentary lifestyle and a less than optimal diet (2). The age-related changes in skeletal muscle mass are attributed to a disruption in the regulation of skeletal muscle protein turnover (3), which results in a chronic imbalance between muscle protein synthesis and breakdown rates. It has been reported that basal protein synthesis rates are either similar (4-7), or reduced (8-14) in the elderly compared with young adults. Furthermore, muscle protein breakdown rates tend to be greater in the elderly, resulting in a gradual loss of skeletal muscle mass (6).

Protein turnover in skeletal muscle tissue is highly responsive to nutrient intake in healthy, young individuals (15). In contrast, the anabolic effect of food intake on muscle protein synthesis seems to be substantially blunted in the elderly $(5,16-18)$. The latter has been proposed to represent a key-factor in the etiology of sarcopenia. In addition to food intake, physical activity can also effectively modulate protein metabolism, as it stimulates both protein synthesis and breakdown (19). However, in the absence of food intake net muscle protein balance will remain negative under these conditions $(19,20)$, leading to net muscle protein loss. Carbohydrate ingestion effectively reduces the activity-induced stimulation of muscle protein degradation, but does not affect protein synthesis $(21,22)$. As a consequence, the protein balance will remain negative $(21,22)$ unless protein and/or amino acids are co-administered (23-25). Interestingly, supplementation with leucine has been proposed as an effective strategy to reduce muscle protein breakdown and to further stimulate muscle protein synthesis $(24$, 26-29). The latter could be attributed to the potential of leucine to stimulate protein anabolism by activating the mRNA translational machinery through the mammalian target of rapamycin (mTOR) in an insulin-dependent and independent manner (30-32). As a result, it has been suggested that the co-ingestion of a mixture of protein and additional free leucine with carbohydrate, could represent an effective strategy to augment muscle protein synthesis and/or to inhibit protein degradation (24).

Under normal living conditions, ADL activities in the morning or afternoon are generally followed by food intake. As such, it is important to determine the combined effects of food intake and physical activity on skeletal muscle protein balance, when studying the proposed changes in skeletal muscle protein metabolism with aging. In the present study, we investigated the differential effects of carbohydrate and carbohydrate with protein and free leucine ingestion on skeletal muscle protein synthesis rates following simulated ADL type activity in young $(\sim 20$ y) and elderly $(\sim 75$ y) lean men. Infusions of L-[ring${ }^{13} \mathrm{C}_{6}$ ]phenylalanine and $\mathrm{L}$-[ring- ${ }^{2} \mathrm{H}_{2}$ ] tyrosine were combined with plasma and 
skeletal muscle tissue sampling to simultaneously measure whole-body protein turnover as well as mixed muscle protein fractional synthetic rates in vivo in men.

\section{Methods}

\section{Subjects}

Eight healthy, elderly men (75 \pm 1 y) and eight weight-matched, young controls $(20 \pm 1 \mathrm{y})$, with no history of participating in any regular exercise training program, were selected to participate in the present study. Subjects' characteristics are shown in table 6.1. All subjects were informed about the nature and risks of the experimental procedure before their written informed consent to participate was obtained. This study was approved by the local Medical Ethical Committee.

Table 6.1 Subjects' characteristics

\begin{tabular}{|c|c|c|}
\hline & Young $(n=8)$ & Elderly $(n=8)$ \\
\hline Age (yrs) & $20 \pm 1$ & $75 \pm 1.2 *$ \\
\hline Weight (kg) & $73.7 \pm 3.2$ & $75.5 \pm 2.1$ \\
\hline Height (m) & $1.81 \pm 0.03$ & $1.72 \pm 0.01 *$ \\
\hline $\mathrm{BMI}\left(\mathrm{kg} \cdot \mathrm{m}^{-2}\right)$ & $22.5 \pm 1.1$ & $25.7 \pm 0.8 *$ \\
\hline Leg volume $(\mathrm{L})$ & $9.43 \pm 0.39$ & $8.23 \pm 0.32 *$ \\
\hline $\mathrm{HbA}_{1 \mathrm{C}}(\%)$ & $5.03 \pm 0.17$ & $5.71 \pm 0.11 *$ \\
\hline Basal glucose $\left(\mathrm{mmol} \cdot \mathrm{L}^{-1}\right)$ & $5.26 \pm 0.12$ & $5.51 \pm 0.10$ \\
\hline Basal insulin $\left(\mathrm{mU} \cdot \mathrm{L}^{-1}\right)$ & $11.15 \pm 0.75$ & $10.15 \pm 0.85$ \\
\hline HOMA-(IR) & $2.61 \pm 0.19$ & $2.48 \pm 0.20$ \\
\hline 1RM leg press (kg) & $203.8 \pm 7.4$ & $151.3 \pm 7.6 *$ \\
\hline 1RM leg press $\left(\mathrm{kg} \cdot \mathrm{BW}^{-1}\right)$ & $2.80 \pm 0.17$ & $2.00 \pm 0.06 *$ \\
\hline 1RM leg extension $(\mathrm{kg})$ & $107.5 \pm 3.8$ & $78.1 \pm 4.3 *$ \\
\hline 1RM leg extension $\left(\mathrm{kg} \cdot \mathrm{BW}^{-1}\right)$ & $1.48 \pm 0.09$ & $1.03 \pm 0.04 *$ \\
\hline
\end{tabular}

Values are expressed as means \pm SEM. HOMA-IR, Homeostasis model assessment of insulin resistance (22); 1RM, one-repetition maximum. * Significantly different from young, $\mathrm{P}<0.05$.

\section{Pretesting}

Before selection in the study, all volunteers were subjected to an oral glucose tolerance test $(33,34)$. Leg volume was determined as described previously (35), after which all subjects participated in an orientation trial to become familiarized with the physical activity protocol and the equipment. Proper lifting technique was demonstrated and practiced for each of the 2 lower-limb exercises (leg press and leg extension). Subsequently, maximal strength (one-repetition maximum, 1RM) was estimated using the multiple repetitions testing procedure (36).

\section{Diet and activity prior to testing}

All subjects consumed a standardized meal $\left(64.1 \pm 2.0 \mathrm{~kJ} \cdot \mathrm{kg}^{-1}\right.$ body weight, consisting of $65 \mathrm{Energy} \%(\mathrm{En} \%)$ carbohydrate, $15 \mathrm{En} \%$ protein and $20 \mathrm{En} \%$ fat) the evening before the trials. All volunteers were instructed to refrain from any 
sort of heavy physical exercise and to keep their diet as constant as possible $3 \mathrm{~d}$ before the trials. In addition, subjects were asked to record their food intake for $48 \mathrm{~h}$ before the start of the first experimental trial and to consume the same diet $48 \mathrm{~h}$ before the start of the second trial.

\section{Experimental trials}

Each subject participated in 2 experiments, separated by $7 \mathrm{~d}$, in which drinks containing carbohydrate $(\mathrm{CHO})$ or carbohydrate, protein and leucine $(\mathrm{CHO}+\mathrm{PRO}+\mathrm{leu})$ were administered in a randomized and double-blind fashion. Each experiment lasted $\sim 8 \mathrm{~h}$. Repeated boluses of a given test-drink were ingested following the physical activity protocol to ensure a continuous supply of glucose and amino acids. Plasma and muscle samples were collected during a $6 \mathrm{~h}$ period. These experiments were designed to simultaneously assess whole-body amino acid kinetics and FSR of mixed muscle protein by the incorporation of L-[ring${ }^{13} \mathrm{C}_{6}$ ]phenylalanine in the mixed protein of muscle biopsies collected from the vastus lateralis muscle.

\section{Protocol}

At $8.00 \mathrm{am}$, after an overnight fast, subjects arrived at the laboratory by car or public transportation and a Teflon catheter was inserted into an antecubital vein for stable isotope infusion. A second Teflon catheter was inserted in a heated dorsal hand vein of the contra-lateral arm, placed in a hot-box $\left(60^{\circ} \mathrm{C}\right)$, for arterialized blood sampling. After basal blood sample collection, a single intravenous dose of $\mathrm{L}$-[ring- $\left.{ }^{13} \mathrm{C}_{6}\right]$ phenylalanine $\left(2 \mu \mathrm{mol} \cdot \mathrm{kg}^{-1}\right)$ and $\mathrm{L}$-[ring${ }^{2} \mathrm{H}_{2}$ ]tyrosine $\left(0.775 \mu \mathrm{mol} \cdot \mathrm{kg}^{-1}\right)$ was administered to prime the phenylalanine and tyrosine pool. Thereafter, tracer infusion (average infusion rate (IR) of $0.049 \pm 0.001 \mu \mathrm{mol} \cdot \mathrm{kg}^{-1} \cdot \mathrm{min}^{-1}$ for $\mathrm{L}-\left[\right.$ ring- $\left.{ }^{13} \mathrm{C}_{6}\right]$ phenylalanine and $0.019 \pm 0.001$ $\mu \mathrm{mol} \cdot \mathrm{kg}^{-1} \cdot \mathrm{min}^{-1}$ for $\mathrm{L}$-[ring-2 $\left.\mathrm{H}_{2}\right]$ tyrosine) was started and subjects rested in a supine position for $1 \mathrm{~h}$, before engaging in the standardized physical activity protocol. The protocol was designed to simulate $30 \mathrm{~min}$ of moderate intensity physical activity (for example garden tasks as lawn mowing) as has been recommended by several public health authorities $(37,38)$. The energy consumption during such an activity pattern is estimated to be $\sim 650 \mathrm{~kJ} \cdot 30 \mathrm{~min}^{-1}$ (39), and was simulated by combining low-intensity cycling and light resistancetype exercise. After 5 min of self-paced cycling, subjects performed 6 sets of 10 repetitions on the horizontal leg press machine (Technogym BV, Rotterdam, The Netherlands) and 6 sets of 10 repetitions on the leg extension machine (Technogym BV). The first 2 sets of both resistance exercises were performed at $40 \%$ of the subjects' 1 RM. Sets $3-4$, and 5-6 were performed at $55 \%$ and $75 \%$ of 1RM, respectively, with 2 min rest intervals between sets. As such, the young and elderly, lean men performed exercise at the same relative intensity. At the end of the exercise protocol $(\mathrm{t}=0 \mathrm{~min})$, subjects rested supine and an arterialized blood sample and a muscle biopsy from the vastus lateralis muscle were collected. 
Subjects then received an initial bolus $\left(1.33 \mathrm{ml} \cdot \mathrm{kg}^{-1}\right)$ of a given test drink. Repeated boluses $\left(1.33 \mathrm{ml} \cdot \mathrm{kg}^{-1}\right)$ were ingested every $30 \mathrm{~min}$ until $\mathrm{t}=330 \mathrm{~min}$. Arterialized blood samples were collected at $\mathrm{t}=15,30,45,60,75,90,120,150,180,210,240$, $270,300,330$ and 360 min with a second muscle biopsy taken at $t=360$ min from the contralateral limb.

Table 6.2 Beverage composition

\begin{tabular}{lcc}
\hline Test drink & CHO & CHO+PRO+leu \\
\hline Whey protein & - & 60 \\
Leucine & - & 10 \\
Glucose & 92 & 92 \\
Maltodextrin & 92 & 92 \\
Sodium saccharinate & & \\
Citric acid & 0.2 & 0.2 \\
Cream vanilla & 1.8 & 1.8 \\
& 5 & 5 \\
Water & up to $1.00 \mathrm{~L}$ & \\
\hline
\end{tabular}

Values expressed in $\mathrm{g} \cdot \mathrm{L}^{-1}$ beverage.

\section{Beverages}

Subjects received a beverage volume of $1.33 \mathrm{ml} \cdot \mathrm{kg}^{-1}$ every 30 min to ensure a given dose of $0.49 \mathrm{~g}$ carbohydrate $\mathrm{kg}^{-1}$ ( $50 \%$ as glucose and $50 \%$ as maltodextrin) with or without the addition of $0.16 \mathrm{~g}^{\cdot} \mathrm{kg}^{-1}$ of a whey protein hydrolysate and $0.03 \mathrm{~g} \cdot \mathrm{kg}^{-1}$ leucine every h. The total amount of protein provided in the $\mathrm{CHO}+\mathrm{PRO}+$ leu experiment by far exceeds the calculated amount of protein needed to provide sufficient precursor substrate to sustain maximal protein synthesis rates for at least $6 \mathrm{~h}$ (40). Repeated boluses were administered to enable a continuous supply of amino acids in the circulation, preventing perturbations in L-[ring$\left.{ }^{13} \mathrm{C}_{6}\right]$ phenylalanine and $\mathrm{L}$-[ring- ${ }^{2} \mathrm{H}_{2}$ ]tyrosine enrichments. The whey protein hydrolysate $(68.8 \%$ protein) contained $10.3 \%$ leucine and consequently the total amount of leucine administered in the $\mathrm{CHO}$ and $\mathrm{CHO}+\mathrm{PRO}+$ leu experiment was

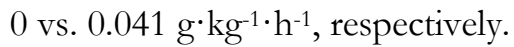

The compositions of all test drinks are listed in table 6.2. Glucose and maltodextrin were obtained from AVEBE (Veendam, The Netherlands). Whey protein hydrolysate was prepared by DSM Food Specialties (Delft, The Netherlands). Leucine was purchased from BUFA (Uitgeest, The Netherlands). To make the taste comparable in all experiments, beverages were uniformly flavored by adding $0.2 \mathrm{~g}$ sodium-saccharinate solution $(25 \% \mathrm{w} / \mathrm{w}), 1.8 \mathrm{~g}$ citric acid solution $(50 \%$ $\mathrm{w} / \mathrm{w}$ ) and $5 \mathrm{~g}$ of cream vanilla flavor (Numico Research, Wageningen, The 
Netherlands) for each liter of beverage. Experiments were performed in a randomized order, with test-drinks provided in a double-blind fashion.

\section{Analysis}

Blood samples were collected in EDTA containing tubes and centrifuged at $1000 \mathrm{~g}$ and $4^{\circ} \mathrm{C}$ for $5 \mathrm{~min}$. Aliquots of plasma were frozen in liquid nitrogen and stored at $-80^{\circ} \mathrm{C}$. Plasma glucose (Uni Kit III, 07367204, Roche, Basel, Switzerland) concentrations were analyzed with the COBAS-FARA semi-automatic analyzer (Roche). Insulin was analyzed by radio immunoassay (Insulin RIA kit, LINCO Research Inc., St. Charles, MO, USA). Plasma $(500 \mu \mathrm{L})$ for amino acid analyses was deproteinized on ice with $100 \mu \mathrm{L}$ of $24 \%$ (w/v) 5 -sulphosalicylic acid, mixed and the clear supernatant was collected after centrifugation. Plasma amino acid concentrations were analyzed on an automated dedicated amino acid analyzer (LCA10, Shimadzu Benelux, Den Bosch, The Netherlands), using an automated precolumn derivatization procedure and a ternary solvent system (14). The exact phenylalanine and tyrosine concentrations in the infusates (4.442 \pm 0.005 and $1.762 \pm 0.003 \mathrm{mmol} \cdot \mathrm{L}^{-1}$, respectively) were measured using the same method. Plasma phenylalanine and tyrosine were derivatized to their tert-butyldimethylsilyl (TBDMS) derivatives and their ${ }^{13} \mathrm{C}$ and/or ${ }^{2} \mathrm{H}$ enrichments were determined by electron ionization gas chromatography-mass spectrometry (GC-MS, Agilent 6890N GC/5973N MSD Little Falls, USA) using selected ion monitoring of masses 336 and 342 for unlabeled and labeled phenylalanine respectively and masses 466, 468 and 472 for unlabeled and labeled tyrosine (46).

For measurement of $\mathrm{L}$-[ring- ${ }^{13} \mathrm{C}_{6}$ ]phenylalanine enrichment in the free amino acid pool and mixed muscle protein, $55 \mathrm{mg}$ of wet muscle was freeze-dried. Collagen, blood and other non-muscle fiber material were removed from the muscle fibers under a light microscope. The isolated muscle fiber mass $(2-3 \mathrm{mg})$ was weighed and 8 volumes ( $8 \mathrm{x}$ dry weight of isolated muscle fibers $\mathrm{x}$ wet/dry ratio) of ice-cold $2 \%$ perchloric acid (PCA) were added. The tissue was then homogenized and centrifuged. The supernatant was collected and processed in the same manner as the plasma samples, such that intracellular free L-[ring- $\left.{ }^{13} \mathrm{C}_{6}\right]$ phenylalanine, L-[ring${ }^{2} \mathrm{H}_{2}$ ] tyrosine and L-[ring- ${ }^{13} \mathrm{C}_{6}$ ] tyrosine enrichments could be measured using their $\mathrm{t}$ butyldimethylsilyl derivatives on a GCMS. The free amino acid concentration in the supernatant was measured using an HPLC technique, after precolumn derivatization with o-phthaldialdehyde (35). The protein pellet was washed with 3 additional $1.5 \mathrm{ml}$ washes of $2 \%$ PCA, dried and the proteins were hydrolyzed in $6 \mathrm{M} \mathrm{HCl}$ at $120^{\circ} \mathrm{C}$ for $15-18 \mathrm{~h}$. The hydrolyzed protein fraction was dried under a nitrogen stream while heated to $120^{\circ} \mathrm{C}$, then dissolved in a $50 \%$ acetic acid solution, and passed over a Dowex exchange resin (AG 50W-X8, 100-200 mesh hydrogen form, Biorad, Hercules, CA, USA) using 2M NH4OH. Thereafter, the eluate was dried and the purified amino acid fraction was derivatized into the $\mathrm{N}$ acetyl-methyl (NAM)-esters to determine the ${ }^{13} \mathrm{C}$-enrichment of protein bound phenylalanine enrichment using GC-IRMS (Finnigan, MAT 252). 


\section{Calculations}

Infusion of L-[ring- $\left.{ }^{-13} \mathrm{C}_{6}\right]$ phenylalanine and $\mathrm{L}$-[ring- $\left.{ }^{2} \mathrm{H}_{2}\right]$ tyrosine with muscle and arterialized blood sampling was used to simultaneously assess whole-body amino acid kinetics and fractional synthetic rate (FSR) of mixed muscle protein. Wholebody kinetics for phenylalanine and tyrosine were calculated using the equations described by Thompson et al. (34) and Short et al. (32). Briefly, phenylalanine and tyrosine turnover (flux, Q) was measured from the isotope dilution at isotopic steady state:

$$
Q=i \cdot\left(\frac{E i}{E p}-1\right)
$$

where $\mathrm{i}$ is the isotope infusion rate $\left(\mu \mathrm{mol} \cdot \mathrm{kg}\right.$ body weight $\left.\mathrm{t}^{-1} \cdot \mathrm{h}^{-1}\right)$ and Ei and Ep correspond to the enrichments of infusate and plasma amino acids, respectively. At isotopic steady state, protein flux $(\mathrm{Q})$ equals the sum of protein synthesis $(\mathrm{S})$ and oxidation $(\mathrm{O})$ as well as the sum of the rate of appearance of meal protein from the gut (I) and protein breakdown (B), whole-body protein synthesis rate was calculated as flux minus oxidation.

$$
\begin{aligned}
& Q=5+\mathcal{J}=3+ \\
& S=Q-O
\end{aligned}
$$

At isotopic steady state, whole-body phenylalanine oxidation can be determined from the conversion (hydroxylation) of L-[ring- $\left.{ }^{13} \mathrm{C}_{6}\right]$ phenylalanine to L-[ring${ }^{13} \mathrm{C}_{6}$ ] tyrosine. The rate of hydroxylation (Qpt) was calculated (32) using the formula,

$$
Q_{p t}=Q_{t} \cdot \frac{E_{t}}{E_{p}} \cdot \frac{Q_{p}}{\left(,-Q_{p}\right)}
$$

where Qt and Qp are the flux rates for L-[ring- $\left.{ }^{2} \mathrm{H}_{2}\right]$ tyrosine and labeled phenylalanine, respectively. Et and Ep are the L-[ring- $\left.{ }^{-13} \mathrm{C}_{6}\right]$ tyrosine and L-[ring$\left.{ }^{13} \mathrm{C}_{6}\right]$ phenylalanine enrichments in plasma, respectively and ip is the infusion rate of the phenylalanine tracer.

Fractional rate of mixed muscle protein synthesis (FSR) was calculated by dividing the increment in enrichment in the product, i.e. protein-bound L-[ring$\left.{ }^{13} \mathrm{C}_{6}\right]$ phenylalanine, by the enrichment of the precursor. Plasma L-[ring$\left.{ }^{13} \mathrm{C}_{6}\right]$ phenylalanine and free muscle L-[ring- $\left.{ }^{13} \mathrm{C}_{6}\right]$ phenylalanine enrichments were used to provide an estimate of the lower boundary (based on plasma precursor enrichments) and the higher boundary (based on intracellular muscle precursor enrichments) for the true fractional synthetic rate of mixed muscle proteins. Muscle FSR's were calculated as follows (20):

$$
F S R=\frac{\Delta E p \cdot 2}{E_{\text {precursor }} \cdot t} \cdot 100
$$


Where $\Delta \mathrm{Ep}$ is the delta increment of protein bound $\mathrm{L}-\left[\mathrm{ring}-{ }^{13} \mathrm{C}_{6}\right]$ phenylalanine during incorporation periods. $\mathrm{E}_{\text {precursor }}$ is (I) the average plasma L-[ring${ }^{13} \mathrm{C}_{6}$ ]phenylalanine enrichment during the time period for determination of amino acid incorporation; (II) the free muscle L-[ring- $\left.{ }^{13} \mathrm{C}_{6}\right]$ phenylalanine enrichment in muscle biopsy taken at $6 \mathrm{~h}$ post-exercise; (III) the free muscle L-[ring${ }^{13} \mathrm{C}_{6}$ ]phenylalanine enrichment in muscle biopsy taken at $6 \mathrm{~h}$ post-exercise corrected for the contribution of extra-cellular water, as previously described (41). $t$ indicates the time interval $(\mathrm{h})$ between biopsies and the factor 100 is needed to express the FSR in percent per hour $\left(\% \cdot \mathrm{h}^{-1}\right)$. The factor 2 arises because in the NAM-ester of L-[ring- ${ }^{13} \mathrm{C}_{6}$ ]phenylalanine molecule 6 of a total of 12 carbon atoms are labeled.

\section{Statistics}

All data are expressed as means_SEM. The plasma essential amino acid, insulin and glucose responses were calculated as area under the curve above baseline values. A three-factor repeated measures ANOVA with age-group, time and treatment as factors was used to compare differences between treatments over time between groups. For non-time dependent variables, a two-factor ANOVA with age-group and treatment as factors was used to compare differences in treatment effects between groups. In case of significant difference between experiments, a Scheffé post-hoc test was applied to locate these differences. Statistical significance was set at $\mathrm{P}<0.05$. All calculations were performed using StatView 5.0 (SAS Institute inc., Cary, NC, USA).

\section{Results}

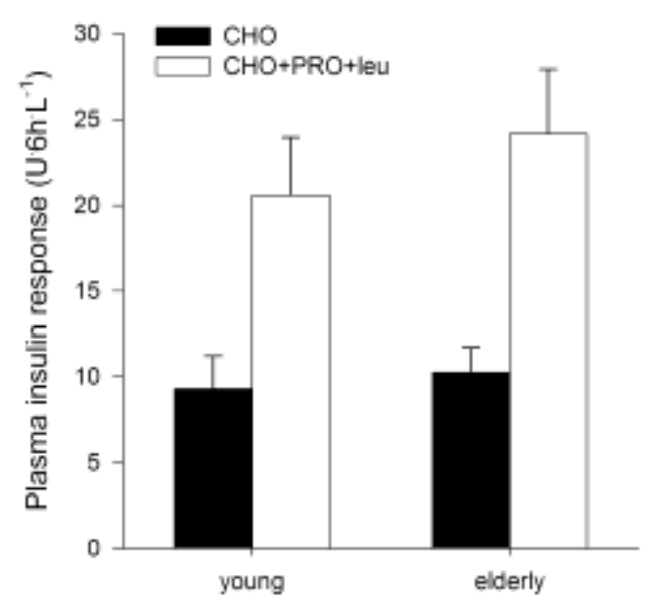

Figure 6.1 Plasma insulin response (expressed as area under the curve minus baseline values) in lean young $(\mathrm{n}=8)$ and elderly $(\mathrm{n}=8)$ men while ingesting carbohydrate $\left(0.49 \mathrm{~g}^{\cdot \mathrm{kg}^{-1}} \cdot \mathrm{h}^{-1} ; \mathrm{CHO}\right)$, or carbohydrate with protein and leucine $\left(0.49,0.16\right.$ and $0.1 \mathrm{~g} \cdot \mathrm{kg}^{-1} \cdot \mathrm{h}^{-1}$, respectively; $\left.\mathrm{CHO}+\mathrm{PRO}+\mathrm{leu}\right)$. Values are means $\pm \mathrm{SEM}$. Data were analyzed with ANOVA (age-group $\mathrm{x}$ treatment): age-group effect, $\mathrm{P}=0.423$; treatment effect, $\mathrm{P}<0.001$; interaction of agegroup and treatment, $\mathrm{P}=0.636$. 


\section{Plasma analyses}

The insulin response, expressed as area under the curve above baseline values (AUC) during the entire $6 \mathrm{~h}$ post-exercise period is shown in figure 6.1. The glucose response (AUC), was significantly lower in the young subjects compared with the elderly (estimated marginal means: $587 \pm 42$ vs. $869 \pm 39 \mathrm{mmol} \cdot 6 \mathrm{~h} \cdot \mathrm{L}^{-1}$, respectively, $\mathrm{P}<0.01)$.

Plasma leucine, phenylalanine and tyrosine concentrations over time are reported in figure 6.2. Basal ( $\mathrm{t}=-120 \mathrm{~min})$ plasma leucine concentrations were significantly lower in the elderly compared with the young $\left(99.0 \pm 3.8\right.$ vs. $119.7 \pm 2.7 \mu \mathrm{mol} \cdot \mathrm{L}^{-1}$, respectively, $\mathrm{P}<0.05)$. No differences were observed between the young and elderly in basal ( $\mathrm{t}=-120 \mathrm{~min}$ ) plasma phenylalanine and tyrosine concentrations. The plasma leucine response (AUC) was negative in the $\mathrm{CHO}$ and positive in the $\mathrm{CHO}+\mathrm{PRO}+$ leu experiment (estimated marginal means: $-13.9 \pm 2.9$ vs. 137.2 \pm 2.9 $\mathrm{mmol} \cdot 6 \mathrm{~h} \cdot \mathrm{L}^{-1}$, respectively, $\mathrm{P}<0.01$. The observed plasma insulin responses were positively correlated with the observed plasma leucine concentration $(r=0.675$, $\mathrm{P}<0.001)$. The plasma phenylalanine response (AUC) was negative in the $\mathrm{CHO}$, whereas it was positive in the $\mathrm{CHO}+\mathrm{PRO}+$ leu experiment (estimated marginal means: $-3.24 \pm 0.34$ vs. $1.87 \pm 0.34 \mathrm{mmol} \cdot 6 \mathrm{~h} \cdot \mathrm{L}^{-1}$, respectively; $\left.\mathrm{P}<0.01\right)$. Plasma tyrosine responses (AUC) were negative in the $\mathrm{CHO}$ and positive in the $\mathrm{CHO}+\mathrm{PRO}+$ leu experiment in the young $\left(-5.8 \pm 0.5\right.$ vs. $3.1 \pm 0.6 \mathrm{mmol} \cdot 6 \mathrm{~h} \cdot \mathrm{L}^{-1}$, respectively; $\mathrm{P}<0.01)$ and elderly $\left(-5.6 \pm 0.3\right.$ vs. $5.7 \pm 0.8 \mathrm{mmol} \cdot 6 \mathrm{~h} \cdot \mathrm{L}^{-1}$, respectively; $\mathrm{P}<0.01)$. The plasma tyrosine response in the $\mathrm{CHO}+\mathrm{PRO}+$ leu experiment was significantly greater in the elderly compared with the young $(\mathrm{P}<0.05)$. The plasma essential amino acid (EAA) response (area under the curve above baseline, with the exception of the supplemented leucine) was negative in the $\mathrm{CHO}$ and positive in the $\mathrm{CHO}+\mathrm{PRO}+$ leu experiment in the young $(-67.8 \pm 3.7 \mathrm{vs} .61 .6 \pm 4.9 \mathrm{mmol} \cdot 6 \mathrm{~h} \cdot \mathrm{L}$ 1 , respectively, $\mathrm{P}<0.01)$ and in the elderly $\left(-57.1 \pm 5.0\right.$ vs. $74.1 \pm 8.1 \mathrm{mmol} \cdot 6 \mathrm{~h} \cdot \mathrm{L}^{-1}$, respectively, $\mathrm{P}<0.01)$, with no differences between the young and elderly.

The time course of the plasma L-[ring- $\left.{ }^{13} \mathrm{C}_{6}\right]$ phenylalanine, L- $\left[\mathrm{ring}_{-}{ }^{2} \mathrm{H}_{2}\right]$ tyrosine and L-[ring- ${ }^{13} \mathrm{C}_{6}$ ] tyrosine enrichments are shown in figure 6.3. Plasma L-[ring${ }^{13} \mathrm{C}_{6}$ ]phenylalanine and $\mathrm{L}$-[ring- ${ }^{2} \mathrm{H}_{2}$ ]tyrosine enrichments increased in the $\mathrm{CHO}$ experiment in both the young and elderly. In the $\mathrm{CHO}+\mathrm{PRO}+$ leu experiment, plasma L-[ring- $\left.{ }^{13} \mathrm{C}_{6}\right]$ phenylalanine and L-[ring- ${ }^{2} \mathrm{H}_{2}$ ]tyrosine enrichments did not change. Plasma L-[ring- $\left.{ }^{13} \mathrm{C}_{6}\right]$ phenylalanine and $\mathrm{L}-\left[\right.$ ring- $\left.{ }^{2} \mathrm{H}_{2}\right]$ tyrosine enrichments were significantly greater in the $\mathrm{CHO}$ compared with the $\mathrm{CHO}+\mathrm{PRO}+$ leu experiment $(\mathrm{P}<0.05)$. Plasma L-[ring- $\left.{ }^{13} \mathrm{C}_{6}\right]$ phenylalanine and L- $\left[\right.$ ring- $\left.{ }^{2} \mathrm{H}_{2}\right]$ tyrosine enrichments were significantly higher in the elderly in the CHO and $\mathrm{CHO}+\mathrm{PRO}+$ leu experiments compared with the young subjects $(\mathrm{P}<0.05)$. Plasma $\mathrm{L}-\left[\right.$ ring- ${ }^{13} \mathrm{C}_{6}$ ] tyrosine enrichment increased in the $\mathrm{CHO}$, but remained unchanged in the $\mathrm{CHO}+\mathrm{PRO}+$ leu experiment in the young and the elderly subjects. Plasma $\mathrm{L}-\left[\right.$ ring- ${ }^{13} \mathrm{C}_{6}$ ] tyrosine enrichment was significantly higher in the $\mathrm{CHO}$ compared with the $\mathrm{CHO}+\mathrm{PRO}+$ leu experiment $(\mathrm{P}<0.05)$. 

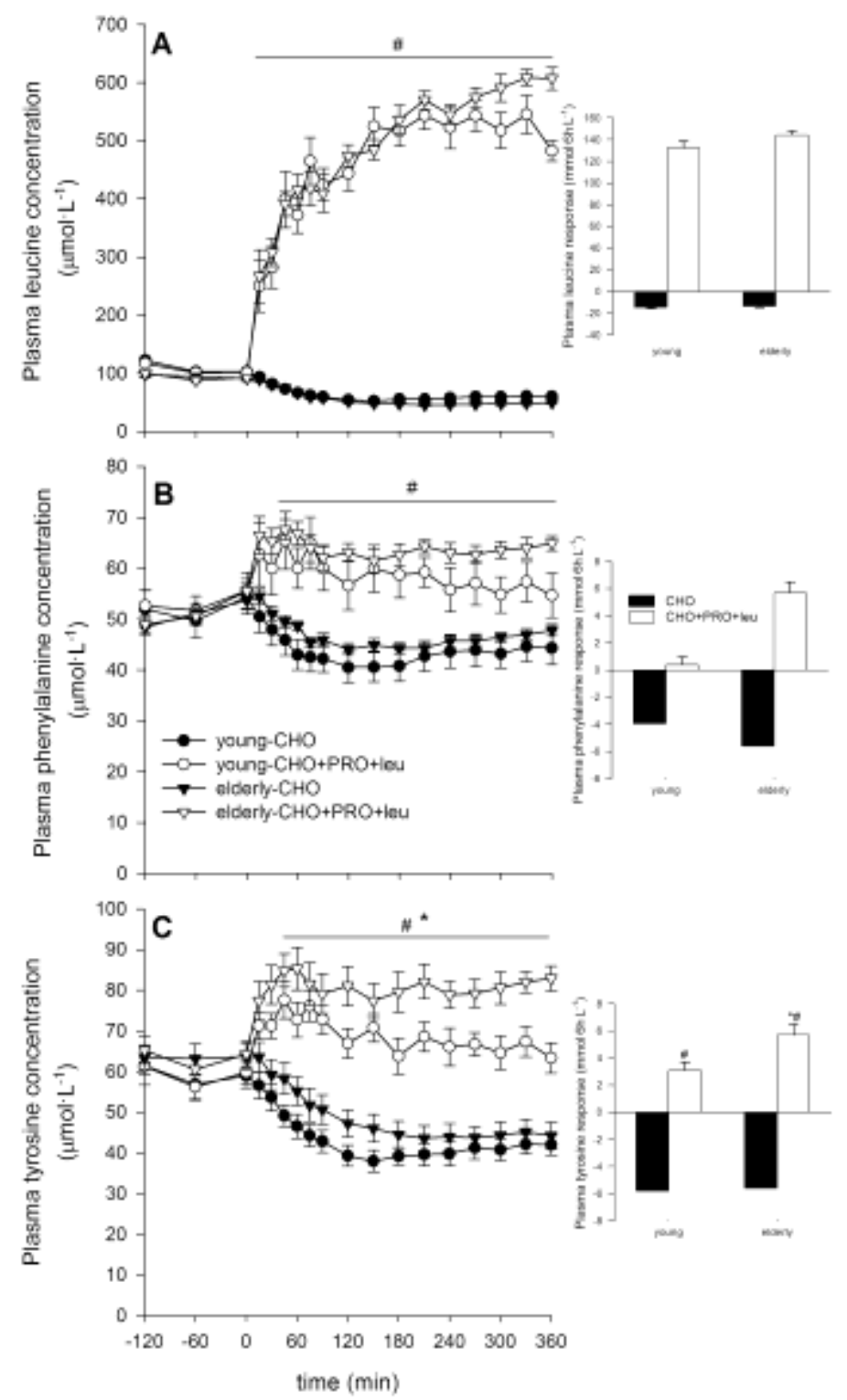

Figure 6.2 Plasma leucine (A), phenylalanine (B), and tyrosine $(C)$ concentrations $\left(\mu m o l . L^{-1}\right)$ and responses, expressed as area under the curve (AUC) above baseline, during the $\mathrm{CHO}$ and $\mathrm{CHO}+\mathrm{PRO}+$ leu experiments in lean young $(n=8)$ and elderly $(n=8)$ men. Values are means \pm SEM. AUC data were analyzed with a two-factor ANOVA (age-group x treatment). Plasma leucine response: age-group effect, $\mathrm{P}=0.10$; treatment effect, $\mathrm{P}<0.001$; interaction of age-group and treatment, $\mathrm{P}=0.186$. Plasma phenylalanine response: age-group effect, $\mathrm{P}<0.05$; treatment effect, $\mathrm{P}<0.001$; interaction of age-group and treatment, $\mathrm{P}=0.596$; Plasma tyrosine response: age-group effect, $\mathrm{P}<0.05$; treatment effect, $\mathrm{P}<0.001$; interaction of age-group and treatment, $\mathrm{P}<0.05$; \# significantly different from $\mathrm{CHO}$ experiment (Scheffé's test, $\mathrm{P}<0.05$ ); * significantly different compared to the young within the $\mathrm{CHO}+\mathrm{PRO}+$ leu experiment (Scheffé's test, $\mathrm{P}<0.05)$. 

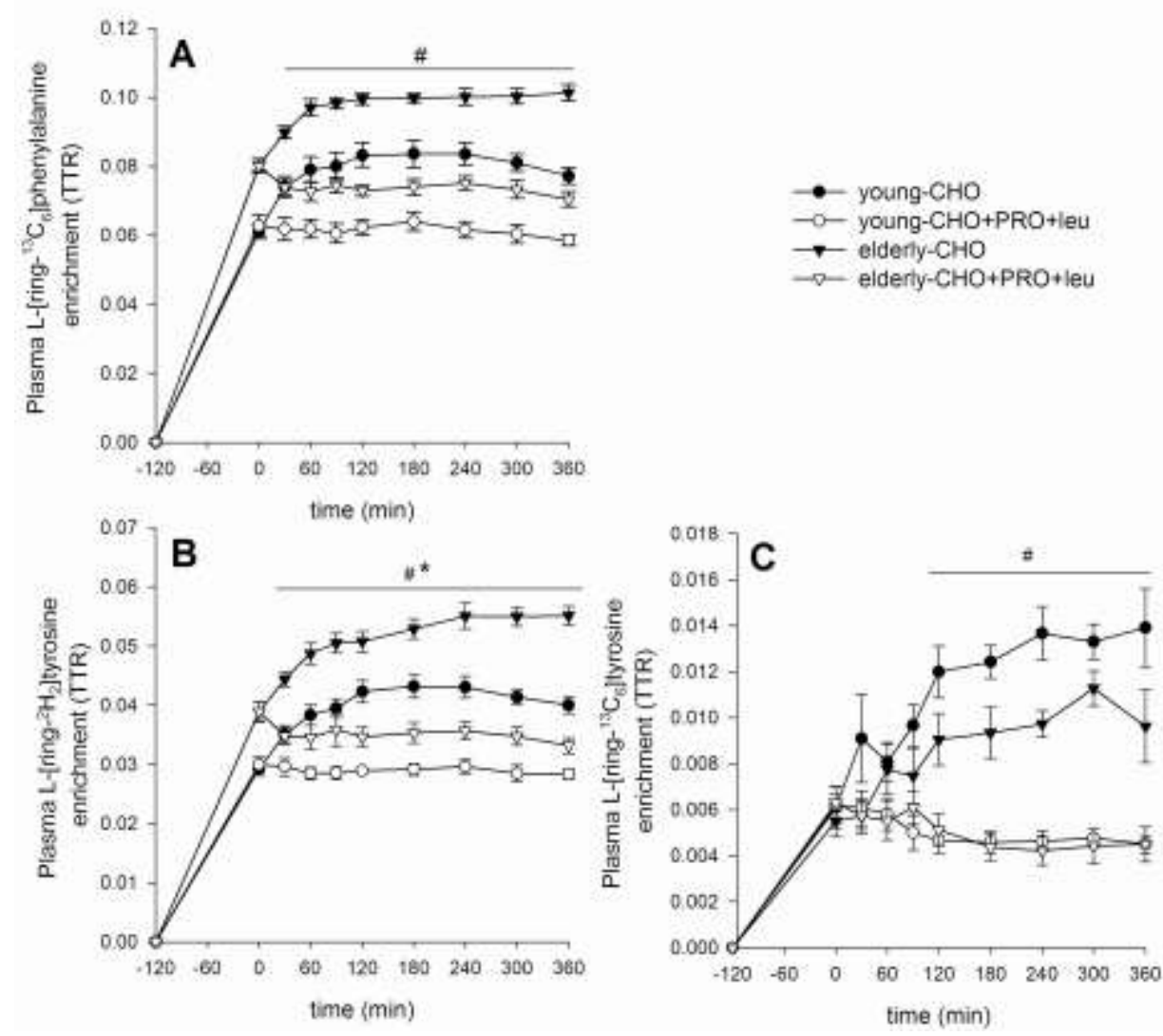

Figure 6.3 Plasma L-[ring- $\left.{ }^{13} \mathrm{C}_{6}\right]$ phenylalanine (A), L-[ring- $\left.{ }^{2} \mathrm{H}_{2}\right]$ tyrosine $(\mathrm{B})$, and L-[ring- $\left.{ }^{13} \mathrm{C}_{6}\right]$ tyrosine enrichment (TTR) (C) during the $\mathrm{CHO}$ and $\mathrm{CHO}+\mathrm{PRO}+$ leu experiments in lean young $(\mathrm{n}=8)$ and elderly $(\mathrm{n}=8)$ men. Values are means \pm SEM. Data were analyzed with ANOVA repeated measures (age-group $\mathrm{x}$ treatment $\mathrm{x}$ time). Plasma L[ring- ${ }^{13} \mathrm{C}_{6}$ ] phenylalanine enrichment: age-group effect, $\mathrm{P}<0.001$; treatment effect, $\mathrm{P}<0.001$; time effect, $\mathrm{P}<0.001$; interaction of age-group and treatment, $\mathrm{P}=0.191$; interaction of age-group and time, $\mathrm{P}<0.001$; interaction of treatment and time, $\mathrm{P}<0.001$; interaction of age-group, treatment and time, $\mathrm{P}=0.339$. Plasma $\mathrm{L}$ - $\left[\mathrm{ring}_{-}{ }^{2} \mathrm{H}_{2}\right]$ tyrosine $_{\text {ine }}$ enrichment: age-group effect, $\mathrm{P}<0.001$; treatment effect, $\mathrm{P}<0.001$; time effect, $\mathrm{P}<0.001$; interaction of age-group and treatment, $\mathrm{P}=0.081$; interaction of age-group and time, $\mathrm{P}<0.001$; interaction of treatment and time, $\mathrm{P}<0.001$; interaction of age-group, treatment and time, $\mathrm{P}<0.001$. Plasma L-[ring- ${ }^{13} \mathrm{C}_{6}$ ]tyrosine enrichment: age-group effect, $\mathrm{P}=0.053$; treatment effect, $\mathrm{P}<0.001$; time effect, $\mathrm{P}<0.001$; interaction of age-group and treatment, $\mathrm{P}=0.053$; interaction of age-group and time, $\mathrm{P}=0.415$; interaction of treatment and time, $\mathrm{P}<0.001$; interaction of age-group, treatment and time, $\mathrm{P}=0.478$. * significant differences between young and elderly (Scheffé's test, $\mathrm{P}<0.05$ ); \# significantly different between treatments (Scheffé's test, $\mathrm{P}<0.05$ ).

\section{Muscle analysis}

No differences in free leucine and tyrosine concentrations in the muscle biopsies taken at $\mathrm{t}=0 \mathrm{~min}$ were observed between the young and elderly. Muscle free phenylalanine concentrations were lower in the elderly compared with the young ( $77 \pm 7$ vs. $160 \pm 32 \mu \mathrm{mol} \cdot \mathrm{L}^{-1}$, respectively, $\mathrm{P}<0.05$ ). At $\mathrm{t}=360 \mathrm{~min}$ muscle leucine concentrations were significantly higher during the $\mathrm{CHO}+\mathrm{PRO}+\mathrm{leu}$ trial compared with the $\mathrm{CHO}$ trial in the young $\left(322 \pm 35\right.$ vs. $83 \pm 11 \mu \mathrm{mol} \cdot \mathrm{L}^{-1}$, 
respectively, $\mathrm{P}<0.05)$ and elderly $\left(232 \pm 38\right.$ vs. $103 \pm 10 \mu \mathrm{mol} \cdot \mathrm{L}^{-1}$, respectively, $\mathrm{P}<0.05)$. Muscle free tyrosine concentrations were significantly higher in the $\mathrm{CHO}+\mathrm{PRO}+$ leu trial when compared with the $\mathrm{CHO}$ trial in the young only $(44 \pm 4$ vs. $57 \pm 4 \mu \mathrm{mol} \cdot \mathrm{L}^{-1}$, respectively, $\left.\mathrm{P}<0.05\right)$. No differences were observed in muscle free phenylalanine concentrations between trials and between the young and elderly at $\mathrm{t}=360 \mathrm{~min}$.

Table 6.3 Plasma and muscle tracer enrichments in young and elderly lean men

\begin{tabular}{|c|c|c|c|c|}
\hline & & \multicolumn{2}{|c|}{ Experiment } & \multirow{2}{*}{$\begin{array}{c}\text { P values } \\
\text { Age/treatment/interaction }\end{array}$} \\
\hline & & $\mathrm{CHO}$ & $\mathrm{CHO}+\mathrm{PRO}+\mathrm{leu}$ & \\
\hline \multicolumn{5}{|c|}{ Plasma AA enrichment } \\
\hline \multicolumn{4}{|c|}{ L-[ring- $\left.{ }^{13} \mathrm{C}_{6}\right]$ phenylalanine } & \multirow{3}{*}{$<0.001 /<0.001 / 0.109$} \\
\hline & Young & $0.0817 \pm 0.0012$ & $0.0614 \pm 0.0009$ & \\
\hline & Elderly & $0.1002 \pm 0.0003$ & $0.0731 \pm 0.0008$ & \\
\hline \multirow{3}{*}{$\mathrm{L}$-[ring- ${ }^{2} \mathrm{H}_{2}$ ] tyrosine } & & & & \multirow[t]{3}{*}{$<0.001 /<0.001 / 0.214$} \\
\hline & Young & $0.0420 \pm 0.0006$ & $0.0289 \pm 0.0002$ & \\
\hline & Elderly & $0.0524 \pm 0.0013$ & $0.0347 \pm 0.0004$ & \\
\hline \multirow[t]{3}{*}{$\mathrm{L}$-[ring $\left.-{ }^{13} \mathrm{C}_{6}\right]$ tyrosine } & & & & \multirow[t]{3}{*}{$<0.01 /<0.01 /<0.05$} \\
\hline & Young & $0.0131 \pm 0.0004$ & $0.0046 \pm 0.0001 *$ & \\
\hline & Elderly & $\begin{array}{l}0.0098 \pm 0.0004 \\
\#\end{array}$ & $0.0045 \pm 0.0002 *$ & \\
\hline \multicolumn{5}{|c|}{ Muscle AA enrichment } \\
\hline \multicolumn{4}{|c|}{ L-[ring- ${ }^{13} \mathrm{C}_{6}$ ] phenylalanine } & \multirow[t]{3}{*}{$<0.001 /<0.001 / 0.573$} \\
\hline & Young & $0.0556 \pm 0.0010$ & $0.0429 \pm 0.0020$ & \\
\hline & Elderly & $0.0639 \pm 0.0036$ & $0.0537 \pm 0.0013$ & \\
\hline \multirow[t]{3}{*}{$\mathrm{L}$-[ring- ${ }^{2} \mathrm{H}_{2}$ ] tyrosine } & & & & \multirow[t]{3}{*}{$0.105 /<0.050 /<0.050$} \\
\hline & Young & $0.0226 \pm 0.0026$ & $0.0218 \pm 0.0014$ & \\
\hline & Elderly & $\begin{array}{l}0.0297 \pm 0.0016 \\
\#\end{array}$ & $0.0209 \pm 0.0010^{*}$ & \\
\hline \multirow[t]{3}{*}{ L-[ring- $\left.{ }^{13} \mathrm{C}_{6}\right]$ tyrosine } & & & & \multirow[t]{3}{*}{$0.858 / 0.070 /<0.05$} \\
\hline & Young & $0.0214 \pm 0.0024$ & $0.0153 \pm 0.0043$ & \\
\hline & Elderly & $0.0214 \pm 0.0020$ & $0.0163 \pm 0.0021$ & \\
\hline \multirow{2}{*}{\multicolumn{4}{|c|}{$\begin{array}{l}\Delta \text { enrichment muscle } \\
\text { protein }\end{array}$}} & \multirow{4}{*}{$0.398 / 0.149 / 0.442$} \\
\hline & & & & \\
\hline & Young & $0.0556 \pm 0.0010$ & $0.0429 \pm 0.0020$ & \\
\hline & Elderly & $0.0639 \pm 0.0036$ & $0.0537 \pm 0.0013$ & \\
\hline
\end{tabular}

Values are means \pm SEM. $\mathrm{n}=8$ elderly and 8 young persons. $\mathrm{CHO}$, carbohydrate; $\mathrm{CHO}+\mathrm{PRO}+$ leu, carbohydrate, protein and leucine; enrichments are expressed as tracer/tracee ratio (TTR). Data were analyzed with ANOVA (age $x$ treatment). Mean plasma amino acid (AA) enrichments during the last $4 \mathrm{~h}$ of recovery. Muscle free amino acid enrichments in the $6 \mathrm{~h}$ post-exercise biopsy. Increments in muscle protein enrichment from 0 to $6 \mathrm{~h}$ following ADL. * Significantly different from CHO experiment (Scheffé's test, P < 0.05). \# Significantly different from values observed in the young (Scheffé's test, $\mathrm{P}<0.05)$.

Mean plasma amino acid enrichment during the last $4 \mathrm{~h}$ of recovery, muscle free amino acid enrichment in the $6 \mathrm{~h}$ post-exercise biopsy and the increment in muscle protein enrichment are presented in table 6.3. Free L-[ring- $\left.{ }^{13} \mathrm{C}_{6}\right]$ phenylalanine enrichments in the $6 \mathrm{~h}$ post-exercise biopsy were significantly higher in the elderly compared with the young in both trials $(\mathrm{P}<0.05)$, while $\mathrm{L}$ - $\left[\right.$ ring- $\left.{ }^{2} \mathrm{H}_{2}\right]$ tyrosine enrichments were higher in the elderly in the $\mathrm{CHO}$ trial only $(\mathrm{P}<0.05)$. No 
differences in muscle free L-[ring- $\left.{ }^{13} \mathrm{C}_{6}\right]$ tyrosine enrichments were observed between the young and elderly in the $\mathrm{CHO}$ and $\mathrm{CHO}+\mathrm{PRO}+\mathrm{leu}$ trials and between trials. Free $\mathrm{L}-\left[\right.$ ring- $\left.{ }^{13} \mathrm{C}_{6}\right]$ phenylalanine enrichments in the $6 \mathrm{~h}$ post-exercise biopsy were significantly higher in the $\mathrm{CHO}$ trial compared with the $\mathrm{CHO}+\mathrm{PRO}+$ leu in both the young and elderly $(\mathrm{P}<0.05)$, while L-[ring${ }^{2} \mathrm{H}_{2}$ ]tyrosine enrichments were lower in the $\mathrm{CHO}+\mathrm{PRO}+$ leu trial in the elderly only $(\mathrm{P}<0.05)$. No differences were observed in the increase in protein-bound L[ring ${ }^{13} \mathrm{C}_{6}$ ] phenylalanine enrichment during the $\mathrm{CHO}$ and $\mathrm{CHO}+\mathrm{PRO}+$ leu trials between the young and elderly.

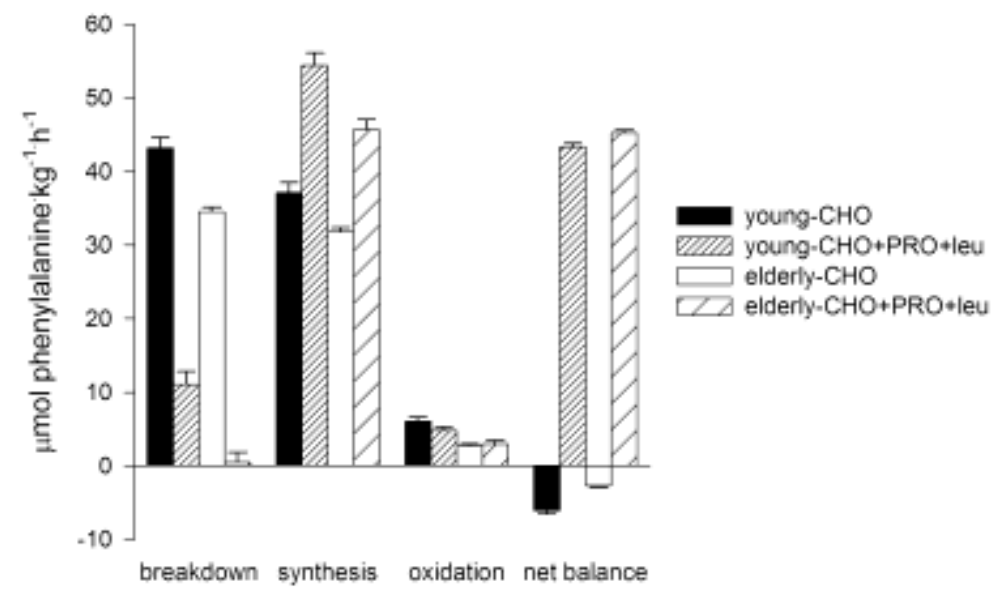

Figure 6.4 The rate of whole-body protein breakdown, synthesis, oxidation and net protein balance (expressed as $\mu \mathrm{mol}$ phenylalanine $\left.\cdot \mathrm{kg} \cdot \mathrm{h}^{-1}\right)$ during the $\mathrm{CHO}$ and $\mathrm{CHO}+\mathrm{PRO}+$ leu experiments in lean young $(\mathrm{n}=8)$ and elderly $(n=8)$ men. Values are means+SEM. Data were analyzed with ANOVA (age-group x treatment). Breakdown: agegroup effect, $\mathrm{P}<0.001$; treatment effect, $\mathrm{P}<0.001$; interaction of age-group and treatment, $\mathrm{P}=0.483$. Synthesis: age-group effect, $\mathrm{P}<0.001$; treatment effect, $\mathrm{P}<0.001$; interaction of age-group and treatment, $\mathrm{P}=0.202$. Oxidation: age-group effect, $\mathrm{P}<0.001$; treatment effect, $\mathrm{P}=0.225$; interaction of age-group and treatment, $\mathrm{P}=0.092$. Net balance: age-group effect, $\mathrm{P}<0.001$; treatment effect, $\mathrm{P}<0.001$; interaction of age-group and treatment, $\mathrm{P}=0.092$.

\section{Whole-body protein metabolism}

Both phenylalanine and tyrosine fluxes were higher in the $\mathrm{CHO}+\mathrm{PRO}+\mathrm{leu}$ trial compared with the $\mathrm{CHO}$ trial in the young $(59.2 \pm 1.8$ vs. $43.2 \pm 1.5 \mu \mathrm{mol}$ phenylalanine $\mathrm{kg}^{-1} \cdot \mathrm{h}^{-1}$, respectively, $\left.\mathrm{P}<0.01\right)$ and elderly subjects $(48.7 \pm 1.35$ vs. $34.6 \pm 0.6 \mu \mathrm{mol}$ phenylalanine $\cdot \mathrm{kg}^{-1} \cdot \mathrm{h}^{-1}$, respectively, $\left.\mathrm{P}<0.01\right)$. Phenylalanine and tyrosine fluxes in the $\mathrm{CHO}$ trial were $20-25 \%$ higher in the young compared with the elderly subjects $(\mathrm{P}<0.01)$. In the $\mathrm{CHO}+\mathrm{PRO}+$ leu trial, phenylalanine and tyrosine fluxes were $30-40 \%$ higher in the young compared with the elderly subjects $(\mathrm{P}<0.01)$. Whole-body protein breakdown (figure 6.4), calculated over the $6 \mathrm{~h}$ of post-exercise recovery, was lower in the $\mathrm{CHO}+\mathrm{PRO}+$ leu trial compared with the $\mathrm{CHO}$ trial $(\mathrm{P}<0.05)$ in the young and elderly. Whole-body protein synthesis (figure 6.4), as calculated by Qp-Qpt, was increased in the $\mathrm{CHO}+\mathrm{PRO}+$ 
leu trial compared with the $\mathrm{CHO}$ trial $(\mathrm{P}<0.01)$ in both groups. The rate of postexercise whole-body phenylalanine oxidation (figure 6.4), as calculated from the conversion of phenylalanine to tyrosine, was decreased in the $\mathrm{CHO}+\mathrm{PRO}+\mathrm{leu}$ trial compared with the CHO trial $(\mathrm{P}<0.05)$ in the young but not in the elderly. Whole-body protein balance (figure 6.4) was negative in the $\mathrm{CHO}$ trial, whereas protein balance was positive in the $\mathrm{CHO}+\mathrm{PRO}+$ leu trial in the young and elderly. Protein breakdown, synthesis and oxidation rates were higher in the young compared with the elderly $(\mathrm{P}<0.05)$. Protein synthesis efficiency (whole-body protein synthesis as a percentage from phenylalanine flux) was significantly higher in the elderly compared with the young subjects in the $\mathrm{CHO}$ trial $(\mathrm{P}<0.01)$, but not in the $\mathrm{CHO}+\mathrm{PRO}+$ leu trial $(\mathrm{P}=0.10)$. Protein synthesis efficiency was increased in the $\mathrm{CHO}+\mathrm{PRO}+$ leu trial compared with the $\mathrm{CHO}$ trial in the young $(91.9 \pm 0.7 \mathrm{vs}$. $86.0 \pm 1.1 \%$, respectively, $\mathrm{P}<0.01$ ), but not in the elderly subjects.

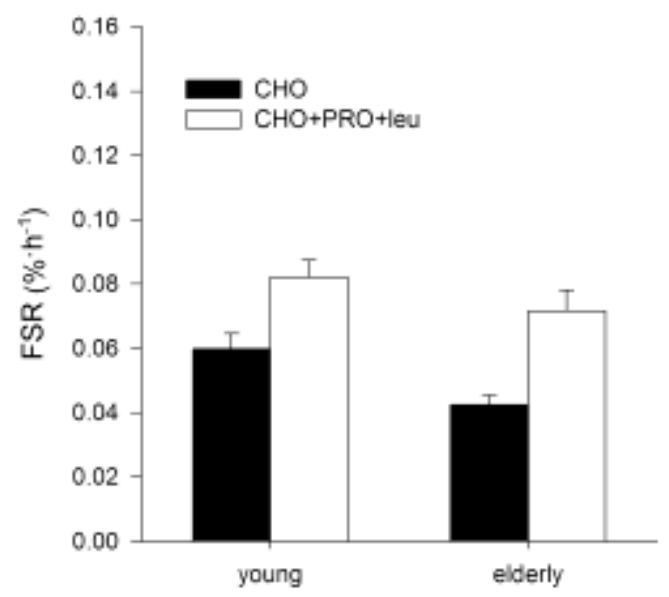

Figure 6.5 Fractional synthetic rate (FSR) of mixed muscle protein following the ingestion of carbohydrate $(\mathrm{CHO})$ or carbohydrate with protein and leucine $(\mathrm{CHO}+\mathrm{PRO}+\mathrm{leu})$ in lean young $(\mathrm{n}=8)$ and elderly $(\mathrm{n}=8)$ men using plasma phenylalanine enrichment as a precursor. Values are means \pm SEM. Data were analyzed with ANOVA (age-group $\mathrm{x}$ treatment). Age-group effect, $\mathrm{P}<0.05$; treatment effect, $\mathrm{P}<0.001$; interaction of agegroup and treatment, $\mathrm{P}=0.583$.

\section{Mixed muscle protein synthesis rates}

Mixed muscle protein fractional synthesis rates (FSR), with the mean plasma L[ring- $\left.{ }^{13} \mathrm{C}_{6}\right]$ phenylalanine enrichment as precursor (figure 6.5), was significantly higher in the $\mathrm{CHO}+\mathrm{PRO}+$ leu trial compared with the $\mathrm{CHO}$ trial in the young $\left(0.082 \pm 0.005 \% \cdot \mathrm{h}^{-1}\right.$ vs. $0.060 \pm 0.005 \% \cdot \mathrm{h}^{-1}$, respectively; $\left.\mathrm{P}<0.01\right)$, and in the elderly $\left(0.072 \pm 0.006 \% \cdot \mathrm{h}^{-1}\right.$ vs. $0.043 \pm 0.003 \% \cdot \mathrm{h}^{-1}$, respectively; $\left.\mathrm{P}<0.01\right)$. The observed FSR values in the elderly subjects were significantly lower than those in the young $(\mathrm{P}<0.05)$. Net differences in the mixed muscle protein synthesis rates between trials were not different between young and elderly subjects $\left(0.022 \pm 0.007 \% \cdot \mathrm{h}^{-1} \mathrm{vs}\right.$. 
$0.029 \pm 0.004 \% \cdot \mathrm{h}^{-1}$, respectively; NS). When the free intracellular L-[ring${ }^{13} \mathrm{C}_{6}$ ]phenylalanine enrichment was used as the precursor, FSR values were higher, but revealed the same intervention effect. FSR values in the young subjects averaged $0.088 \pm 0.008$ and $0.124 \pm 0.011 \% \cdot \mathrm{h}^{-1}$ for the $\mathrm{CHO}$ and $\mathrm{CHO}+\mathrm{PRO}+\mathrm{leu}$ trial, respectively $(\mathrm{P}<0.05)$. In the elderly, FSR values averaged $0.068 \pm 0.005$ and $0.097 \pm 0.008 \% \cdot \mathrm{h}^{-1}$ for the $\mathrm{CHO}$ and $\mathrm{CHO}+\mathrm{PRO}+$ leu trial respectively $(\mathrm{P}<0.01)$. When these values were corrected for the contribution of extra-cellular water to the measured free muscle L-[ring- $\left.{ }^{13} \mathrm{C}_{6}\right]$ phenylalanine enrichment (41), FSR values averaged $0.095 \pm 0.009$ and $0.135 \pm 0.014 \% \cdot \mathrm{h}^{-1}$ for the $\mathrm{CHO}$ and $\mathrm{CHO}+\mathrm{PRO}+\mathrm{leu}$ trial, respectively $(\mathrm{P}<0.05)$. In the elderly, FSR values averaged $0.076 \pm 0.007$ and $0.102 \pm 0.008 \% \cdot \mathrm{h}^{-1}$ for the $\mathrm{CHO}$ and $\mathrm{CHO}+\mathrm{PRO}+$ leu trial respectively $(\mathrm{P}<0.01)$.

\section{Discussion}

In the present study, we assessed whole-body protein turnover and determined mixed muscle protein synthesis rates by measuring the incorporation of labeled phenylalanine in the vastus lateralis muscle following the ingestion of carbohydrate with or without protein and free leucine in young and elderly men. Co-ingestion of protein and leucine is shown to improve whole-body protein balance in both the young and elderly when compared with the ingestion of carbohydrate only. Direct measurement of mixed muscle protein synthesis rates reveals that protein synthesis rates are lower in the elderly compared with the young when ingesting only carbohydrate. However, co-ingestion of protein and leucine substantially increases muscle protein synthesis rates to the same extent in both young and elderly men.

It has been reported that basal muscle protein synthesis rates are similar $(25,38-40)$ or reduced in the elderly $(6,16,30,42,43,48,49)$, while protein degradation rates are increased (40). In addition, there are indications that the stimulating effect of food intake on muscle protein synthesis is blunted in the elderly $(38,44,45)$. Besides food intake, physical activity can also effectively modulate protein metabolism. Under normal living conditions, activities of daily living (ADL) are generally followed by food intake. Therefore, determining the combined effects of food intake and physical activity on skeletal muscle protein metabolism is of crucial importance when investigating the proposed changes in skeletal muscle protein metabolism with aging. In the present study, we investigated the anabolic response to carbohydrate $(\mathrm{CHO})$ ingestion following simulated ADL type activities in vivo in young $(\sim 20$ y) and elderly men $(\sim 75$ y). Consequently, we show that muscle protein synthesis rates are significantly lower in the elderly $(\sim 75$ y) compared with the young $(\sim 20$ y) under such conditions. The observed mixed muscle FSR values following ADL activities were $\sim 30 \%$ lower in the elderly compared with the young subjects (figure 6.5), which would represent a $\sim 5 \%$ decline per decade. These observations are in line with previous reports showing muscle protein synthesis rates to be $20-30 \%$ lower in elderly humans (60-84 yrs) than in young adults in a basal, fasted state $(16,33,44)$. Our findings on the muscle level are in line with our observations using the whole-body tracer methods showing whole-body phenylalanine and tyrosine turnover to be $20-25 \%$ lower in the elderly compared 
with the young. Thus, on a whole-body level, protein synthesis, oxidation and breakdown are reduced in the elderly compared with the young subjects. In accordance to our earlier findings (20), we observed that whole-body net protein balance remains negative when only carbohydrate is ingested. To our knowledge we are the first to show that muscle protein synthesis is reduced in the elderly in practical daily living conditions in which ADL activities are followed by ingestion of carbohydrate only.

Administration of amino acids with or without carbohydrate results in a rapid increase in muscle protein synthesis in young adults, whereas protein degradation rates are being reduced $(10,11,20,24,25,29)$. The latter can be attributed to the role of amino acids as precursors for protein synthesis (47), the potential of amino acids to stimulate insulin secretion (36) and the proposed property of amino acids, and leucine in particular, to stimulate protein synthesis by activating the mRNA translational machinery through the mTOR-pathway (19). The latter has been reported for leucine administration in vivo in rodents (3-5). Therefore, a mixture containing carbohydrate, protein and additional free leucine could therefore likely represents an effective nutritional intervention to optimize net muscle accretion. Recently, we showed that the combined ingestion of protein and free leucine augments skeletal muscle protein synthesis rates in healthy young adults following intense resistance exercise when compared with the ingestion of carbohydrate only (20). In the present study, we aimed to investigate whether the proposed anabolic response to the combined ingestion of protein and leucine would also be present in the elderly when compared with the ingestion of carbohydrate only, and we questioned whether this response is of a similar or lower magnitude in the elderly. In accordance to our earlier findings (20), we observed that whole-body protein breakdown rates were significantly suppressed following co-ingestion of leucine and protein with carbohydrate, whereas protein synthesis rates were increased (figure 6.4). Co-ingestion of protein and leucine with carbohydrate resulted in a $47 \pm 3 \%$ and $44 \pm 4 \%$ increase in whole-body protein synthesis in the young and elderly, respectively, when compared with the ingestion of carbohydrate only. As a result, whole-body protein net-balance became positive in the $\mathrm{CHO}+\mathrm{PRO}+\mathrm{leu}$ trial, which verifies that protein/amino acid ingestion is necessary for net muscle anabolism to occur. The co-ingestion of protein and leucine with carbohydrate increased FSR compared with carbohydrate ingestion only (figure 6.5). The net differences in the mixed muscle protein synthesis rates between the $\mathrm{CHO}$ and $\mathrm{CHO}+\mathrm{PRO}+$ leu trials did not differ between the young and elderly subjects. As such, our data imply that the combined ingestion of protein and leucine with carbohydrate can stimulate muscle protein synthesis to the same extent in young and elderly men. This would be in line with more recent observations, showing a similar response of muscle protein turnover to an amino acid load in healthy elderly and younger adults $(25,37,39)$. However, our FSR data seem to be in contrast with data presented by Volpi et al (38), who showed that the response of muscle protein synthesis to the combined ingestion of amino acids and glucose is impaired in the elderly. The latter could be related to the blunted insulin response in the elderly compared with the young controls that were reported by Volpi et al 
(38). In contrast, we observed similar plasma insulin responses in the young and elderly volunteers following the co-ingestion of protein and leucine with carbohydrate. The observed differences might be attributed to the property of leucine to stimulate insulin secretion (36) and/or mRNA translation (3). In this study, we investigated the potential differences in the capacity to stimulate muscle protein synthesis in the young and elderly following the ingestion of a theoretically optimal anabolic nutritional intervention. The latter shows that these properties are as effective in the young as in the elderly.

In conclusion, co-ingestion of protein and leucine improves whole-body protein balance when compared with the ingestion of carbohydrate only in young and elderly men. Mixed muscle protein synthesis is reduced in the elderly under conditions where ADL activities are followed by food ingestion. However, coingestion of protein with leucine substantially increases mixed muscle protein synthesis rates to the same extent in the young and the elderly, thereby improving whole-body protein balance.

\section{Acknowledgements}

We gratefully acknowledge the expert technical assistance of Joan Senden, Hanne Vandereyt and Jos Stegen and the enthusiastic support of the subjects who volunteered to participate in these trials. This work was partly supported by a grant from Numico Research. 


\section{References}

1. American College of Sports Medicine Position Stand. The recommended quantity and quality of exercise for developing and maintaining cardiorespiratory and muscular fitness, and flexibility in healthy adults. Med Sci Sports Exerc 30: 975-991, 1998.

2. Alberti KG and Zimmet PZ. Definition, diagnosis and classification of diabetes mellitus and its complications. Part 1: diagnosis and classification of diabetes mellitus provisional report of a WHO consultation. Diabet Med 15: 539-553, 1998.

3. Anthony JC, Anthony TG, Kimball SR, Vary TC, and Jefferson LS. Orally administered leucine stimulates protein synthesis in skeletal muscle of postabsorptive rats in association with increased eIF4F formation. J Nutr 130: 139-145, 2000.

4. Anthony JC, Anthony TG, and Layman DK. Leucine supplementation enhances skeletal muscle recovery in rats following exercise. J Nutr 129: 1102-1106., 1999.

5. Anthony JC, Reiter AK, Anthony TG, Crozier SJ, Lang CH, MacLean DA, Kimball SR, and Jefferson LS. Orally Administered Leucine Enhances Protein Synthesis in Skeletal Muscle of Diabetic Rats in the Absence of Increases in 4E-BP1 or S6K1 Phosphorylation. Diabetes 51: 928-936, 2002.

6. Balagopal P, Ljungqvist $\mathrm{O}$, and Nair KS. Skeletal muscle myosin heavy-chain synthesis rate in healthy humans. Am J Physiol 272: E45-50, 1997.

7. Balagopal P, Rooyackers OE, Adey DB, Ades PA, and Nair KS. Effects of aging on in vivo synthesis of skeletal muscle myosin heavy-chain and sarcoplasmic protein in humans. Am J Physiol 273: E790-800, 1997.

8. Biolo G, Maggi SP, Williams BD, Tipton KD, and Wolfe RR. Increased rates of muscle protein turnover and amino acid transport after resistance exercise in humans. Am J Physiol 268: E514-520, 1995.

9. Borsheim E, Cree MG, Tipton KD, Elliott TA, Aarsland A, and Wolfe RR. Effect of carbohydrate intake on net muscle protein synthesis during recovery from resistance exercise. J Appl Physiol 96: 674-678, 2004.

10. Borsheim E, Tipton KD, Wolf SE, and Wolfe RR. Essential amino acids and muscle protein recovery from resistance exercise. Am J Physiol Endocrinol Metab 283: E648657, 2002.

11. Collin-Vidal C, Cayol M, Obled C, Ziegler F, Bommelaer G, and Beaufrere B. Leucine kinetics are different during feeding with whole protein or oligopeptides. Am J Physiol 267: E907-914, 1994.

12. Evans WJ. Protein nutrition, exercise and aging. J Am Coll Nutr 23: 601S-609S, 2004.

13. Evans WJ. What is sarcopenia? J Gerontol A Biol Sci Med Sci 50 Spec No: 5-8, 1995.

14. Fekkes D, van Dalen A, Edelman $M$, and Voskuilen A. Validation of the determination of amino acids in plasma by high-performance liquid chromatography using automated pre-column derivatization with o-phthaldialdehyde. J Chromatogr B Biomed Appl 669: 177-186, 1995.

15. Gunn SM, Brooks AG, Withers RT, Gore CJ, Owen N, Booth ML, and Bauman AE. Determining energy expenditure during some household and garden tasks. Med Sci Sports Exerc 34: 895-902, 2002.

16. Hasten DL, Pak-Loduca J, Obert KA, and Yarasheski KE. Resistance exercise acutely increases MHC and mixed muscle protein synthesis rates in 78-84 and 23-32 yr olds. Am J Physiol Endocrinol Metab 278: E620-626, 2000.

17. Jones PR and Pearson J. Anthropometric determination of leg fat and muscle plus bone volumes in young male and female adults. J Physiol 204: 63P-66P, 1969. 
18. Karlsson HK, Nilsson PA, Nilsson J, Chibalin AV, Zierath JR, and Blomstrand E. Branched-Chain Amino Acids Increase p70S6 Kinase Phosphorylation in Human Skeletal Muscle after Resistance Exercise. Am J Physiol Endocrinol Metab 287: E1-7, 2004.

19. Kimball SR and Jefferson LS. Regulation of global and specific mRNA translation by oral administration of branched-chain amino acids. Biochem Biophys Res Commun 313: 423-427, 2004.

20. Koopman R, Wagenmakers AJ, Manders RJ, Zorenc AH, Senden JM, Gorselink M, Keizer HA, and van Loon LJ. Combined ingestion of protein and free leucine with carbohydrate increases post-exercise muscle protein synthesis in vivo in male subjects. Am J Physiol Endocrinol Metab 288: E645-653, 2005.

21. Liu Z, Jahn LA, Long W, Fryburg DA, Wei L, and Barrett EJ. Branched chain amino acids activate messenger ribonucleic acid translation regulatory proteins in human skeletal muscle, and glucocorticoids blunt this action. J Clin Endocrinol Metab 86: 2136-2143, 2001.

22. Matthews DR, Hosker JP, Rudenski AS, Naylor BA, Treacher DF, and Turner RC. Homeostasis model assessment: insulin resistance and beta-cell function from fasting plasma glucose and insulin concentrations in man. Diabetologia 28: 412-419, 1985.

23. Mayhew JL, Piper FC, and Ware JS. Anthropometric correlates with strength performance among resistance trained athletes. J Sports Med Phys Fitness 33: 159-165, 1993.

24. Pacy PJ, Garrow JS, Ford GC, Merritt H, and Halliday D. Influence of amino acid administration on whole-body leucine kinetics and resting metabolic rate in postabsorptive normal subjects. Clin Sci (Lond) 75: 225-231, 1988.

25. Paddon-Jones D, Sheffield-Moore M, Zhang XJ, Volpi E, Wolf SE, Aarsland A, Ferrando AA, and Wolfe RR. Amino acid ingestion improves muscle protein synthesis in the young and elderly. Am J Physiol Endocrinol Metab 286: E321-328, 2004.

26. Pate RR, Pratt M, Blair SN, Haskell WL, Macera CA, Bouchard C, Buchner D, Ettinger W, Heath GW, King AC, and et al. Physical activity and public health. A recommendation from the Centers for Disease Control and Prevention and the American College of Sports Medicine. Jama 273: 402-407, 1995.

27. Phillips SM, Tipton KD, Aarsland A, Wolf SE, and Wolfe RR. Mixed muscle protein synthesis and breakdown after resistance exercise in humans. Am J Physiol 273: E99107, 1997.

28. Proud CG. mTOR-mediated regulation of translation factors by amino acids. Biochem Biophys Res Commun 313: 429-436, 2004.

29. Rasmussen BB, Tipton KD, Miller SL, Wolf SE, and Wolfe RR. An oral essential amino acid-carbohydrate supplement enhances muscle protein anabolism after resistance exercise. J Appl Physiol 88: 386-392, 2000.

30. Rooyackers OE, Adey DB, Ades PA, and Nair KS. Effect of age on in vivo rates of mitochondrial protein synthesis in human skeletal muscle. Proc Natl Acad Sci USA 93: 15364-15369, 1996.

31. Roy BD, Tarnopolsky MA, MacDougall JD, Fowles J, and Yarasheski KE. Effect of glucose supplement timing on protein metabolism after resistance training. J Appl Physiol 82: 1882-1888, 1997.

32. Short KR, Meek SE, Moller N, Ekberg K, and Nair KS. Whole-body protein kinetics using Phe and Tyr tracers: an evaluation of the accuracy of approximated flux values. Am J Physiol 276: E1194-1200, 1999. 
33. Short KR, Vittone JL, Bigelow ML, Proctor DN, and Nair KS. Age and aerobic exercise training effects on whole-body and muscle protein metabolism. Am J Physiol Endocrinol Metab 286: E92-101, 2004.

34. Thompson GN, Pacy PJ, Merritt H, Ford GC, Read MA, Cheng KN, and Halliday D. Rapid measurement of whole-body and forearm protein turnover using a [2H5]phenylalanine model. Am J Physiol 256: E631-639, 1989.

35. van Eijk HM, Rooyakkers DR, and Deutz NE. Rapid routine determination of amino acids in plasma by high-performance liquid chromatography with a 2-3 microns Spherisorb ODS II column. J Chromatogr 620: 143-148, 1993.

36. van Loon LJ, Saris WH, Verhagen $H$, and Wagenmakers AJ. Plasma insulin responses after ingestion of different amino acid or protein mixtures with carbohydrate. Am J Clin Nutr 72: 96-105, 2000.

37. Volpi E, Ferrando AA, Yeckel CW, Tipton KD, and Wolfe RR. Exogenous amino acids stimulate net muscle protein synthesis in the elderly. J Clin Invest 101: 2000 2007, 1998.

38. Volpi E, Mittendorfer B, Rasmussen BB, and Wolfe RR. The response of muscle protein anabolism to combined hyperaminoacidemia and glucose-induced hyperinsulinemia is impaired in the elderly. J Clin Endocrinol Metab 85: 4481-4490, 2000.

39. Volpi E, Mittendorfer B, Wolf SE, and Wolfe RR. Oral amino acids stimulate muscle protein anabolism in the elderly despite higher first-pass splanchnic extraction. Am J Physiol 277: E513-520, 1999.

40. Volpi E, Sheffield-Moore M, Rasmussen BB, and Wolfe RR. Basal muscle amino acid kinetics and protein synthesis in healthy young and older men. Jama 286: 1206-1212, 2001.

41. Wagenmakers AJ. Tracers to investigate protein and amino acid metabolism in human subjects. Proc Nutr Soc 58: 987-1000, 1999.

42. Welle S, Thornton C, Jozefowicz R, and Statt M. Myofibrillar protein synthesis in young and old men. Am J Physiol 264: E693-698, 1993.

43. Welle S, Thornton C, and Statt M. Myofibrillar protein synthesis in young and old human subjects after three months of resistance training. Am J Physiol 268: E422-427, 1995.

44. Welle S, Thornton C, Statt M, and McHenry B. Postprandial myofibrillar and wholebody protein synthesis in young and old human subjects. Am J Physiol 267: E599-604, 1994.

45. Welle $\mathrm{S}$ and Thornton CA. High-protein meals do not enhance myofibrillar synthesis after resistance exercise in 62- to 75-yr-old men and women. Am J Physiol 274: E677683, 1998.

46. Wolfe RR. Radioactive and stable isotope tracers in biomedicine: principles and practice of kinetic analysis. New York: Wiley-Liss, 1992.

47. Wolfe RR. Regulation of muscle protein by amino acids. J Nutr 132: 3219S-3224S, 2002.

48. Yarasheski KE, Welle S, and Sreekumaran Nair K. Muscle protein synthesis in younger and older men. Jama 287: 317-318, 2002.

49. Yarasheski KE, Zachwieja JJ, and Bier DM. Acute effects of resistance exercise on muscle protein synthesis rate in young and elderly men and women. Am J Physiol 265: E210-214, 1993. 

The increase in S6K1 phosphorylation in human skeletal muscle following resistance exercise occurs mainly in type II muscle fibers

René Koopman, Antoine H.G. Zorenc, Rudy J.J. Gransier, David Cameron-Smith, and Luc J.C. van Loon

Am J Physiol Endocrinol Metab (in press, 2006) 


\begin{abstract}
To investigate the in vivo effects of resistance exercise on translational control in human skeletal muscle, we determined the phosphorylation of AMP activated kinase (AMPK), eukaryotic initiation factor 4E-binding protein (4E-BP1), p70/p85-S6 protein kinase (S6K1) and ribosomal S6 protein (S6). Furthermore, we investigated whether changes in the phosphorylation of S6K1 are muscle fiber-type specific. Eight male subjects performed a single high-intensity resistance exercise session. Muscle biopsies were collected before, immediately after exercise, and following 30 and $120 \mathrm{~min}$ of post-exercise recovery. The phosphorylation status of AMPK, 4E-BP1, S6K1 and S6 was determined by western blotting with phosphospecific and pan antibodies. To determine fiber-type specific changes in the phosphorylation status of S6K1, immunofluorescence microscopy was applied. AMPK phosphorylation was increased $\sim 3$ fold immediately following resistance exercise, while 4E-BP1 phosphorylation was reduced to $27 \pm 6 \%$ of pre-exercise values. Phosphorylation of S6K1 at $\mathrm{Thr}^{421} / \mathrm{Ser}^{424}$ was increased 2-2.5 fold during recovery, but did not induce a significant change in S6 phosphorylation. Phosphorylation of S6K1 was more pronounced in the type II vs. type I muscle fibers. Before exercise, phosphorylated S6K1 was predominantly located in the nuclei. After $2 \mathrm{~h}$ of post-exercise recovery, phospho-S6K1 was primarily located in the cytosol of type II muscle fibers. We conclude that resistance exercise effectively increases the phosphorylation of S6K1 on $\mathrm{Thr}^{421} / \mathrm{Ser}^{424}$, which is not associated with a substantial increase in S6 phosphorylation in a fasted state.
\end{abstract}




\section{Introduction}

Skeletal muscle protein turnover has been shown to be stimulated after an acute bout of resistance exercise $(8,26)$. The process of mRNA translation initiation forms an important regulatory site in the overall control of muscle protein synthesis (5). Recent evidence suggests that the phosphatidylinositol 3-kinase (PI3K) signaling pathway plays a key role in this process $(18,28)$. The activity of the signaling cascade controlling muscle protein synthesis is largely determined by the phosphorylation of the mammalian target of rapamycin (mTOR) and its subsequent activation of the $\mathrm{p} 70 / \mathrm{p} 85 \mathrm{~S} 6$ protein kinase (S6K1) and the eukaryotic initiation factor 4E-binding protein (4E-BP1) (18).

Both S6K1 and 4E-BP1 can modulate translation initiation, and control the binding of mRNA to the $40 \mathrm{~S}$ ribosomal subunit (18). 4E-BP1 can bind to the initiation factor eIF4E, thereby acting as a translational repressor preventing the formation of the eIF4F scaffolding complex, which is necessary for efficient binding of the $40 \mathrm{~S}$ ribosomal subunit to mRNA $(1,14)$. Activation of the mTOR pathway results in 4E-BP1 hyperphosphorylation and a subsequent dissociation of the 4E-BP1·eIF4E complex, allowing it to participate in the translation initiation process. Another mechanism regulating the binding of mRNA to the $40 \mathrm{~S}$ ribosomal subunit involves the phosphorylation of ribosomal protein S6, which is controlled by the activity of S6K1 (1). S6K1 consist of two isoforms: a $70-\mathrm{kDa}$ cytoplasmic isoform (p70-S6K) and an $85-\mathrm{kDa}$ nuclear isoform (p85-S6K) (21). The activation of both S6K1 isoforms has been shown to phosphorylate S6 on the $40 \mathrm{~S}$ subunit in close proximity of the eIFs and mRNA (21). Phosphorylation of S6 is thought to alter the interaction of the protein with these components, thereby promoting mRNA translation (7). Interestingly, in rodents the phosphorylation status of S6K1 following resistance exercise has been reported as an excellent marker for the long-term increase in skeletal muscle mass (2).

It has been speculated that the anabolic response to resistance exercise is muscle fiber-type specific. In accordance, it has been shown that human soleus as opposed to vastus lateralis muscle is less responsive to resistance exercise (32). In rats, the phosphorylation of protein kinase B (PKB or Akt), mTOR and S6K1 following resistance exercise has been reported to be more pronounced in muscle tissue containing a greater proportion type II muscle fibers $(2,25,28)$, as opposed to those muscle groups containing more type I fibers (25). Moreover, by applying immuno-histochemistry in rat tibialis muscle, it was recently shown that mTOR phosphorylation is selectively increased in type IIa fibers for up to several $\mathrm{h}$ after resistance exercise (25). Data on the activation of the translation initiation machinery in human skeletal muscle remain scarce $(9,16)$. Information on the potential muscle fiber-type specific changes in the phosphorylation status of proteins involved in translation initiation response to exercise in humans is still lacking.

Both S6K1 and mTOR have been reported to be localized in the cytosol (36). However, recent studies have reported these proteins to be localized both in the 
cytosol as well as in the nuclei of human embryonic kidneys (HEK) 293 cells (17). The latter implies that sub-cellular localization of mTOR and/or S6K1 could play a functional role. In HEK 293 cells, nuclear import of mTOR has been shown to enhance 4E-BP1 phosphorylation and S6K1 activation, whereas nuclear export of mTOR attenuated the phosphorylation/activation, suggesting that both activation of S6K1 and phosphorylation of 4E-BP1 require nuclear mTOR (17). Similar nuclear transport has also been reported for S6K1 (17). These observations suggest that the intracellular cytosolic and/or nuclear localization of these key regulatory proteins represent a level of control in the regulation of skeletal muscle protein synthesis. So far, the sub-cellular localization of S6K1 and the subsequent changes that occur in response to resistance exercise have not been studied in human muscle.

The purpose of the present study was to investigate the mode of activation of the mRNA translation initiation machinery downstream of mTOR in skeletal muscle tissue following a single bout of resistance exercise in vivo in humans. Besides measuring the phosphorylation state of S6K1, 4E-BP1 and S6, we aimed to investigate whether changes in S6K1 phosphorylation are specific for muscle fibertype and/or sub-cellular localization.

\section{Methods}

\section{Subjects}

Eight healthy male volunteers with no history of participating in any regular exercise program were recruited to participate in the present study. Subjects' characteristics are shown in table 7.1. All subjects were informed on the nature and possible risks of the experimental procedures, before their written informed consent was obtained. This study was approved by the Medical Ethical Committee of the Academic Hospital Maastricht.

Table 7.1 Subjects' characteristics

\begin{tabular}{lc}
\hline & Mean \pm SEM \\
\hline Age (yrs) & $22.5 \pm 0.9$ \\
Weight $(\mathrm{kg})$ & $74.9 \pm 2.8$ \\
Height $(\mathrm{m})$ & $1.80 \pm 0.01$ \\
BMI $\left(\mathrm{kg} \cdot \mathrm{m}^{-2}\right)$ & $23.3 \pm 0.7$ \\
$\%$ bodyfat $(\%)$ & $17.8 \pm 2.4$ \\
Fat free mass $(\mathrm{kg})$ & $61.3 \pm 2.1$ \\
Fat mass $(\mathrm{kg})$ & $13.6 \pm 2.1$ \\
HbA1C $(\%)$ & $5.3 \pm 0.1$ \\
1RM leg press $(\mathrm{kg})$ & $198 \pm 7$ \\
1RM leg extension $(\mathrm{kg})$ & $105 \pm 3$ \\
\hline
\end{tabular}

Values are expressed as means \pm SEM. 


\section{Pretesting}

Body composition was assessed using the hydrostatic weighing method in the morning following an overnight fast. Residual lung volume was measured by the helium-dilution technique using a spirometer (Volugraph 2000, Mijnhart, Bunnik, The Netherlands). Body weight was measured with a digital balance with an accuracy of $0.001 \mathrm{~kg}$ (E1200, August Sauter GmbH, Albstadt, Germany). Body fat percentage was calculated using Siri's equation (30). Fat free mass (FFM) was calculated by subtracting fat mass from total body mass.

To familiarize subjects with the resistance exercise protocol and the equipment, a familiarization trial was performed. Proper lifting technique was demonstrated and practiced for each of the 2 lower-limb exercises (leg press and leg extension) and for the 3 upper-body exercises (chest press, shoulder press and lat-pulldown). Thereafter, maximum strength was estimated using the multiple repetitions testing procedure (22).

In an additional exercise session, at least 1 week before the experimental trial, the subjects' 1 repetition maximum (1RM) was determined (20). After warming up, the load was set at $90-95 \%$ of the estimated 1RM, and increased after each successful lift until failure. A $5 \mathrm{~min}$ resting period between subsequent attempts was allowed. A repetition was valid if the subject was able to complete the entire lift in a controlled manner without assistance.

\section{Standardization diet and activity prior to testing}

All subjects received a strict standardization diet for 2 days prior to the resistance exercise test trial, which was performed in the morning after an overnight fast. Subjects were provided with a pre-weighed amount of food products, beverages, and instant meals and were allowed to drink water ad libitum. Subjects were instructed to take all main meals (breakfast, lunch, and dinner) and between-meal snacks at predetermined time intervals during each day. The standardization diet provided $0.15 \mathrm{MJ} \cdot \mathrm{kg}^{-1} \cdot \mathrm{day}^{-1}$ containing $15 \mathrm{Energy} \%(\mathrm{En} \%)$ of protein, $30 \mathrm{En} \%$ of fat and $55 \mathrm{En} \%$ of carbohydrate. All volunteers were instructed to refrain from any sort of heavy physical exercise during the 2 days prior to the test-trial.

\section{Experimental trial}

The day of the test, subjects arrived at the laboratory by car or public transportation at $8.00 \mathrm{am}$, following an overnight fast. After $30 \mathrm{~min}$ of supine rest, a basal blood sample was collected and a muscle biopsy was taken from the vastus lateralis muscle. Thereafter, subjects performed a 5 min low-intensity warm-up on a cycle-ergometer, followed by 3 sets of 10 repetitions on 3 resistance exercise machines targeting upper-body muscle groups (chestpress, shoulderpress and latpulldown, Jimsa Benelux BV, Rotterdam, The Netherlands). The latter were included to provide a whole-body warm-up to reduce the risk of injury. Thereafter, subjects performed 8 sets of 10 repetitions on the horizontal leg press machine (Technogym BV, Rotterdam, The Netherlands) and 8 sets of 10 repetitions on the 
leg extension machine (Technogym). Both exercises were performed at $75 \%$ of the individual $1 \mathrm{RM}$ with $2 \mathrm{~min}$ rest intervals between sets and required $\sim 45 \mathrm{~min}$ to complete. All subjects were verbally encouraged during the exercise session to complete the entire protocol. Immediately after cessation of exercise, a second muscle biopsy sample was taken, after which the subjects rested supine for $2 \mathrm{~h}$. After $30 \mathrm{~min}$ and $2 \mathrm{~h}$ of post-exercise recovery, additional muscle biopsies were taken.

\section{Muscle biopsies}

Muscle biopsy samples were collected from both legs. The first two biopsies were taken from the same incision in one leg; the last two were taken from the same incision in the contra-lateral leg. When biopsy samples were taken from the same incision, the first sample was taken from a different region (distal of the incision, with the needle pointing inwards) than the second (proximal with the needle pointing outwards). Muscle biopsies were obtained from the middle region of the $\mathrm{m}$. vastus lateralis $(15 \mathrm{~cm}$ above the patella) and approximately $3 \mathrm{~cm}$ below entry through the fascia using the percutaneous needle biopsy technique (3).

Muscle samples were freed from any visible non-muscle material and rapidly frozen in liquid nitrogen. Muscle samples $(\sim 40 \mathrm{mg})$ for Western blotting analyses were freeze-dried and collagen, blood and other non-muscle fiber material were removed from the muscle fibers under a light microscope. The isolated muscle fiber mass $(6-10 \mathrm{mg})$ was weighed and 8 volumes $(8 \mathrm{x}$ dry weight of isolated muscle fibers $\mathrm{x}$ wet/dry ratio) of ice-cold buffer $\left(20 \mathrm{mmol} \cdot \mathrm{L}^{-1}\right.$ HEPES (pH 7.4), 100 $\mathrm{mmol} \cdot \mathrm{L}^{-1} \mathrm{KCl}, 50 \mathrm{mmol} \cdot \mathrm{L}^{-1}$ beta-glycerophosphate, $\mathrm{mmol} \cdot \mathrm{L}^{-1} \mathrm{NaF}, 1 \mathrm{mmol} \cdot \mathrm{L}^{-1}$ dithiothreitol, $0.5 \mathrm{mmol} \cdot \mathrm{L}^{-1} \mathrm{Na}_{3} \mathrm{VO}_{4}, 0.2 \mathrm{mmol} \cdot \mathrm{L}^{-1}$ EDTA, $0.1 \mathrm{mmol} \cdot \mathrm{L}^{-1} \mathrm{PMSF}$ and $1 \mathrm{mmol} \cdot \mathrm{L}^{-1}$ benzamidine) was added (4). The tissue was then homogenized, after which homogenates were centrifuged for $5 \mathrm{~min}$ at $1000 \mathrm{~g}$ and at $4^{\circ} \mathrm{C}$. Thereafter, the supernatant was centrifuged at $10000 \mathrm{~g}$ at $4^{\circ} \mathrm{C}$ for $10 \mathrm{~min}$, resolved in SDS-buffer and boiled for 5 minutes at $100^{\circ} \mathrm{C}$.

About $20 \mathrm{mg}$ of each muscle sample were frozen in liquid nitrogen-cooled isopentane and embedded in Tissue-Tek for immunohistochemical analysis (Sakura Finetek, Zoeterwoude, The Netherlands).

\section{Muscle sample analysis}

\section{Antibodies}

Polyclonal primary phospho-specific antibodies (anti-phospho S6K1 $\left(\mathrm{Thr}^{221}\right.$ /Ser ${ }^{424}$ ), anti-phospho S6 ( $\mathrm{Ser}^{235 / 230)}$, anti-phospho 4E-BP1 $\left(\mathrm{Thr}^{37}\right)$ and antiphospho AMPK $\alpha_{1,2}\left(\mathrm{Thr}^{172}\right)$ and anti-S6K1, anti-S6, anti-4E-BP1 and antiAMPK $\alpha_{1,2}$ were purchased from Cell Signaling Technologies (Beverly, MA, USA). Anti-caveolin-3 was from BD biosciences (San Jose, CA USA) and the monoclonal antibody raised against adult human slow myosin heavy chain (or A4.951) was from Developmental Studies Hybridoma Bank, developed by Dr. Blau. Appropriate secondary conjugated antibodies (GARIgGAlexa555 and 
GAMIgG1Alexa488) were purchased from Molecular Probes (Leiden, The Netherlands).

\section{Western blotting}

Equal amounts of protein (40 $\mu \mathrm{g} / \mathrm{lane})$ were run on either 10\% (S6K1 and S6) or $12 \%$ (AMPK and 4E-BP1) SDS-polyacrylamide gels (200 V, mini protein 3 cell, Biorad, Hercules, CA) and proteins were transferred ( $2 \mathrm{~h} 250 \mathrm{~mA}$, Criterion blotter, Biorad, Hercules, CA) to $0.45 \mathrm{~mm}$ nitrocellulose membranes. After Ponceau $\mathrm{S}$ staining and de-staining, membranes were blocked in 5\% Non Fat Dry Milk Powder (NFDM) (Biorad, Hercules, CA) in Tris buffered saline containing 0.1\% Tween-20 (TBS-T) for 1h. Thereafter, a 1:1000 dilution of the primary (phospho) specific antibody (all from Cell Signaling Technology) in 5\% NFDM/TBS-T was added and incubated overnight at $4^{\circ} \mathrm{C}$ on a shaker. After washing the membranes 4 times $5 \mathrm{~min}$ in $15 \mathrm{ml} 5 \% \mathrm{NFDM} / \mathrm{TBS}-\mathrm{T}$, the membranes were incubated with a 1:10 000 dilution of the horseradish peroxidase-conjugated secondary antibody (Pierce) in 5\% NFDM/TBS-T. Thereafter, the membranes were washed in $25 \mathrm{ml}$ of TBS-T for 5, 15, 5 and 5 min. Light sensitive film (CL-Xposure; Pierce) was used to detect immunoreactive bands using chemiluminescent substrate (SuperSignal CL; Pierce). Autoradiographic film was scanned densitometrically and quantification was performed using the program Quantity One version 4.2.1. (Biorad). Alpha actin was used to standardize for the amount of protein loaded. Phosphorylation of AMPK, 4E-BP1, S6K1 and S6 was expressed relative to the total amount of each protein. Data was analyzed as the \% change in phosphorylation state from pre-exercise values for each subject.

\section{Immunobistochemistry}

Multiple serial sections $(5 \mu \mathrm{m})$ from biopsy samples collected before, immediately after, 30 and 120 min after exercise were thaw-mounted together on uncoated, precleaned glass slides for each subject, carefully aligned for cross-sectional analysis. Sections were fixed for $5 \mathrm{~min}$ in methanol, followed by $1 \mathrm{~min}$ in acetone. Slides were then incubated overnight at $4{ }^{\circ} \mathrm{C}$ with anti-caveolin-3 and anti-phospho S6K1 antibodies (1:200 and 1:50 in PBS, respectively). Slides were rinsed for 3x 5 min with PBS and then incubated for 45 min with appropriate secondary antibodies diluted together with $5 \mu \mathrm{g} \cdot \mathrm{ml}^{-1}$ 4',6-Diamidino-2-phenylindole (DAPI; to visualize nuclei) in PBS. After several washes with PBS, stained sections were embedded in Mowiol ${ }^{\circledR}$ and covered with a coverslip. All muscle cross-sections were stained and prepared within a single batch using the same antibody-preparation to minimize variability in staining efficiency. Serial sections were stained for slow MHC with the monoclonal A4.951 antibody to determine the proportion and cross-sectional area of type I and II muscle fibers, which was measured as previously described (33).

After 24h, glass slides were examined using a Nikon E800 fluorescence microscope (Uvikon, Bunnik, The Netherlands) coupled to a Basler A113 C progressive scan color CCD camera, with a Bayer color filter. Epifluorescence signal was recorded using a Texas red excitation filter $(540-580 \mathrm{~nm})$ for S6K1, a 
fluorescein isothiocyanate (FITC) excitation filter (465-495 nm) for caveolin-3, and a 4',6-diamidino-2-phenylindole (DAPI) UV excitation filter $(340-380 \mathrm{~nm})$ for the nuclei.

Digitally captured images (240x magnification) with five fields-of-view per muscle cross-section (12 \pm 1 fibers per field-of-view), were processed and analyzed using Lucia 4.81 software (Nikon, Düsseldorf, Germany). The phospho-S6K1 specific fluorescence signal was quantified for each muscle fiber, resulting in a total of $60 \pm 2$ muscle fibers analyzed for each muscle cross-section ( $32 \pm 2$ type I and $27 \pm 2$ type II muscle fibers) and for each muscle nuclei, resulting in a total of $117 \pm 7$ muscle fiber nuclei analyzed for each muscle cross-section ( $58 \pm 5$ nuclei of type I and $59 \pm 5$ nuclei of type II muscle fibers). Muscle nuclei were selected based on the DAPI staining. An intensity threshold representing minimal intensity values corresponding to nuclear phospho-S6K1 was set manually and uniformly used for all images. Phospho-S6K1 content of muscle nuclei was expressed as the percentage of the nuclear area that was stained. Intracellular phospho-S6K1 content was expressed as mean staining intensity.

\section{Statistics}

All data are expressed as means \pm SEM. Analyses of variance (ANOVA) for repeated measures were applied to determine differences in phosphorylation status in the protein of interest over time. In case of a significant F-ratio, a Scheffé posthoc test was applied to locate the differences. AMPK phosphorylation status before and after exercise were compared using a paired t-test. Statistical significance was set at $\mathrm{P}<0.05$.

\section{Results}

\section{Resistance exercise}

Mean 1 repetition maximum (1RM) measured during the pre-test was $198 \pm 7 \mathrm{~kg}$ on the horizontal leg press and $105 \pm 3 \mathrm{~kg}$ on the leg extension exercise. Therefore, average weight lifted during the resistance exercise was set at $148 \pm 5$ and $79 \pm 3 \mathrm{~kg}$ for the leg press and leg extension respectively. All subjects completed 8 sets with 10 repetitions on the leg press. One subject was unable to finish 10 repetitions during the $6^{\text {th }}$ set, after which resistance was reduced to $65 \%$ of the individual 1RM. All subjects completed 8 sets of 10 repetitions on the leg extension machine.

\section{Western blotting results}

Western blotting with phospho-specific antibodies showed that AMPK phosphorylation was increased 3 -fold following resistance exercise $(\mathrm{P}<0.05)$. $\mathrm{Thr}^{172}$ phosphorylation of AMPK assessed with western blotting is shown in figure 7.1. $\mathrm{Thr}^{37}$ phosphorylation of 4E-BP1 assessed with western blotting is presented in figure 7.2. 4E-BP1 phosphorylation was reduced immediately after resistance 
exercise $(\mathrm{P}<0.05)$, after which they returned to baseline values after $30 \mathrm{~min}$ of recovery. After $120 \mathrm{~min}$ of post-exercise recovery, 4E-BP1 phosphorylation was significantly reduced compared to resting values $(\mathrm{P}<0.05)$.

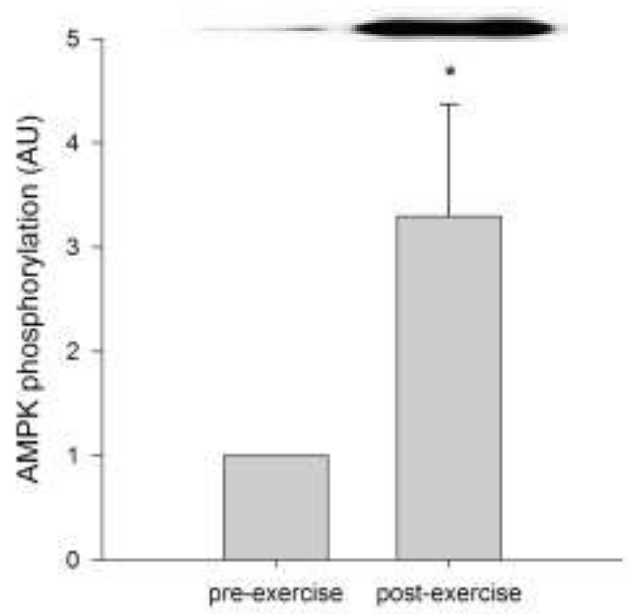

Figure 7.1 AMPK phosphorylation at $\mathrm{Thr}^{172}$ in vastus lateralis muscle at rest, immediately post-exercise and after 30 and $120 \mathrm{~min}$ of post-exercise recovery. Representative immunoblots are shown (top). Values are means+SEM; * significantly different from resting values.

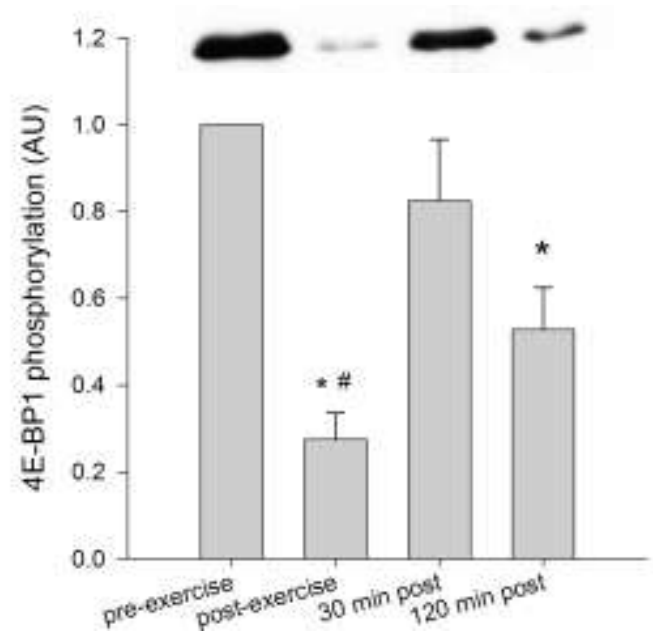

Figure 7.2 4E-BP1 phosphorylation at $\mathrm{Thr}^{37}$ in vastus lateralis muscle at rest, immediately post-exercise and after 30 and 120 min of post-exercise recovery. Representative immunoblots are shown (top). Values are means+SEM; * significantly different from resting values; \# significantly different from values observed after 30 min of postexercise recovery. 
$\mathrm{Thr}^{421} / \mathrm{Ser}^{424}$ phosphorylation of S6K1 assessed with western blotting is shown in figure 7.3. Following resistance exercise, S6K1 phosphorylation was increased and was significantly higher 30 min post-exercise compared to basal resting values $(\mathrm{P}<0.05)$. Ser $235 / 236$ phosphorylation of $\mathrm{S} 6$ assessed with western blotting is presented in figure 7.4. No significant differences in S6 phosphorylation were observed following exercise.

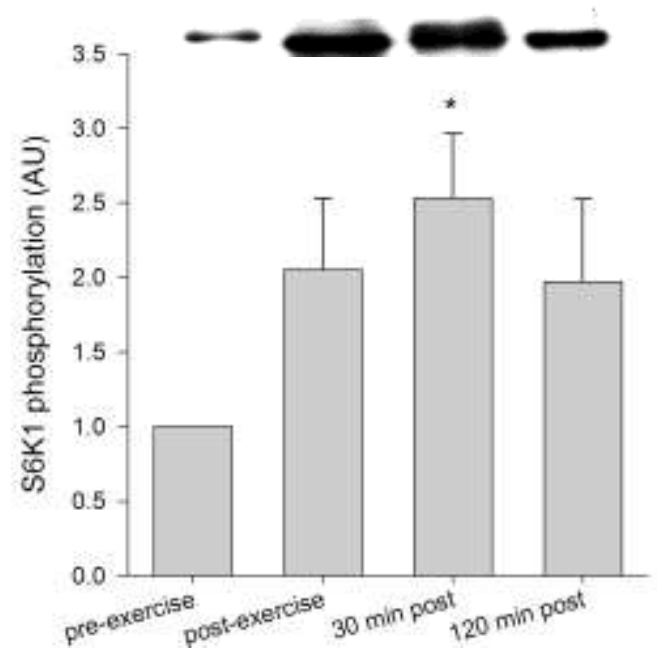

Figure 7.3 S6K1 phosphorylation at $\mathrm{Thr}^{421} / \mathrm{Ser}^{424}$ in vastus lateralis muscle at rest, immediately post-exercise and after 30 and $120 \mathrm{~min}$ of post-exercise recovery. Representative immunoblots are shown (top). Values are means + SEM; * significantly different from resting values. $(\mathrm{P}<0.05)$.

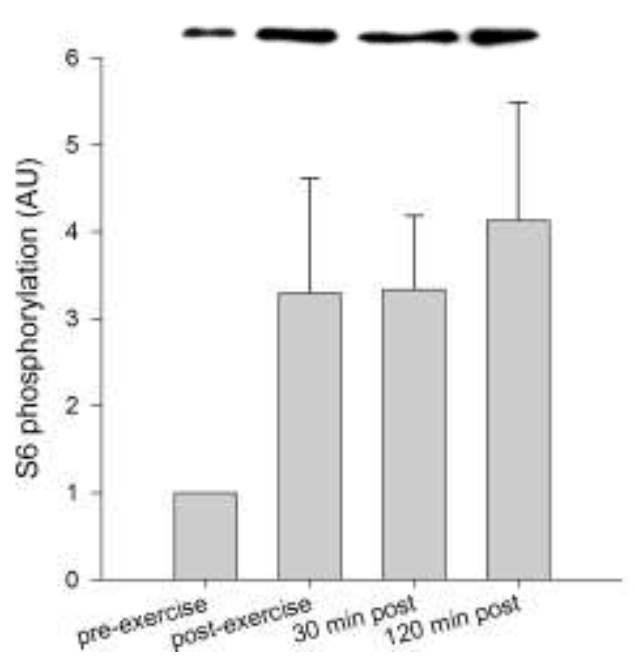

Figure 7.4 S6 phosphorylation at $\mathrm{Ser}^{235 / 236}$ in vastus lateralis muscle at rest, immediately post-exercise and after 30 and 120 min of post-exercise recovery. Representative immunoblots are shown (top). Values are means+SEM. No differences were observed over time. 

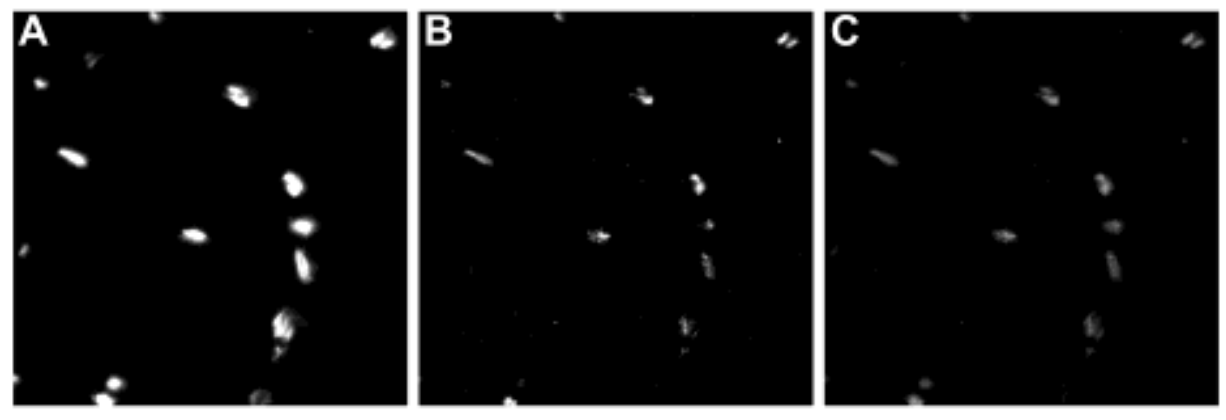

Figure 7.5 Immunofluorescent images (360x magnification) of muscle nuclei (A) and S6K1 (Thr $\left.{ }^{421} / \mathrm{Ser}^{424}\right)(\mathrm{B})$ in the pre-exercise muscle biopsies showing nuclear localization of phospho-S6K1 (C). The nuclei were stained using DAPI.

\section{Immunohistological analyses}

Western blotting with phospho-specific antibodies showed that $\mathrm{Thr}^{421} / \mathrm{Ser}^{424}$ phosphorylation of S6K1 was increased following resistance exercise and was significantly higher $30 \mathrm{~min}$ post-exercise compared to the observed resting values. Using immuno-histochemical techniques we were able to quantify changes in localization and phosphorylation of S6K1 in a fiber-type specific manner. To determine the cellular localization of S6K1 in muscle fibers, we used immunofluorescence staining of the muscle membrane, nuclei and S6K1 ( $\left.\mathrm{Thr}^{421} / \mathrm{Ser}^{424}\right)$. As presented in figure 7.5, staining for phospho-specific S6K1 in the pre-exercise muscle biopsies shows a predominant localization of phospho-S6K1 in the nuclei. However, after $2 \mathrm{~h}$ of post-exercise recovery we show a marked increase in phosphorylated S6K1 present in the cytosol (figure 7.6). In figure 7.6, images of representative cross-sections of vastus lateralis muscle obtained before and 120 min after exercise with sections stained for phospho-S6K1 are presented. Phosphorylation of S6K1 was increased following resistance exercise in both the type I and type II fibers (figure 7.7; P<0.05). However phosphorylation of S6K1 increased to a greater extent in the type II fibers compared to the type I fibers (figure 7.7; $\mathrm{P}<0.05$ ). At $30 \mathrm{~min}$ after the resistance exercise session nuclear phospho-S6K1 content was increased in the type II fibers only $(\mathrm{P}<0.05)$.

On average, muscle samples taken from the vastus lateralis muscle consisted for $53 \pm 2 \%$ of type I and $47 \pm 3 \%$ of type II muscle fibers. Type II muscle fibers had a significantly greater cross sectional area compared to the type I fibers $(5243 \pm 331$ vs. $\left.4668 \pm 240 \mu \mathrm{m}^{2}, \mathrm{P}<0.05\right)$. No differences between fiber-types were observed in average number of myonuclei per muscle fiber cross-section $(2.1 \pm 0.3$ vs. $2.3 \pm 0.2$ nuclei per fiber for type I and II muscle fibers, respectively; NS). In addition, nuclei area did not differ between type I and II muscle fiber $(31.8 \pm 0.9$ vs. $31.7 \pm 1.0$ $\mu \mathrm{m}^{2}$, respectively). 

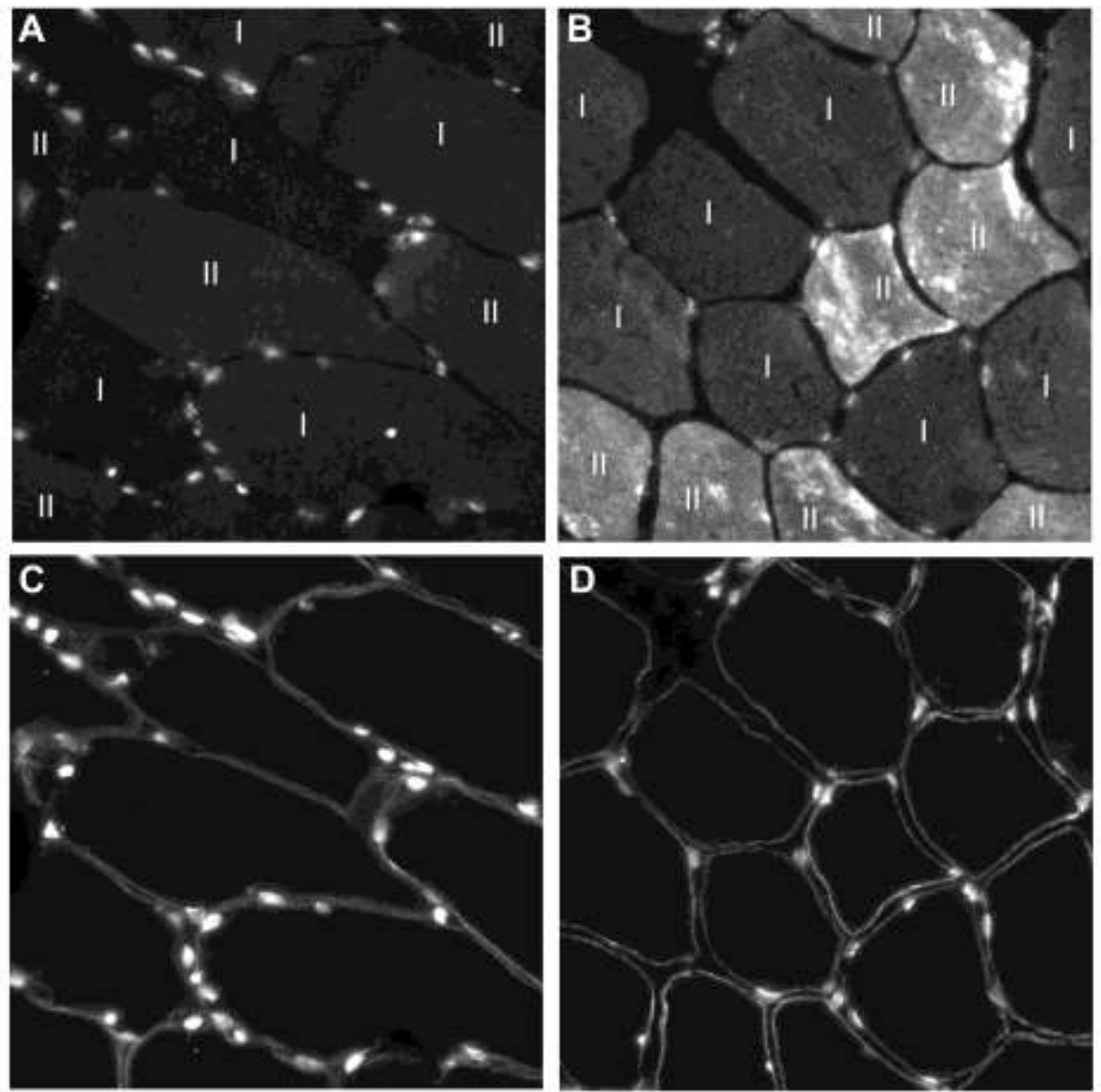

Figure 7.6 Images (240x magnification) of representative cross-sections of vastus lateralis muscle showing primarily nuclear localization of phospho-S6K1 in muscle samples obtain before exercise (A). Phospho-S6K1 is primarily located in the cytosol of type II muscle fibers after $2 \mathrm{~h}$ of post-exercise recovery (B). Staining for caveolin-3 and nuclei are shown in panel C and D (showing the cell membranes in green and nuclei in blue). The muscle fibers are labeled as type I and type II.

\section{Discussion}

In the present study, we show that a single bout of resistance exercise leads to the phosphorylation of S6K1 in human skeletal muscle in a fiber-type-dependent manner, with the most pronounced phosphorylation being observed in the type II muscle fibers. The phosphorylation of S6K1 observed following exercise was not accompanied by a substantial activation of S6K1. The latter could, in part, be attributed to the observed immediate exercise induced increase in AMPK phosphorylation, which has been shown to induce reductions in 4E-BP1 phosphorylation and S6K1 activation (4). 

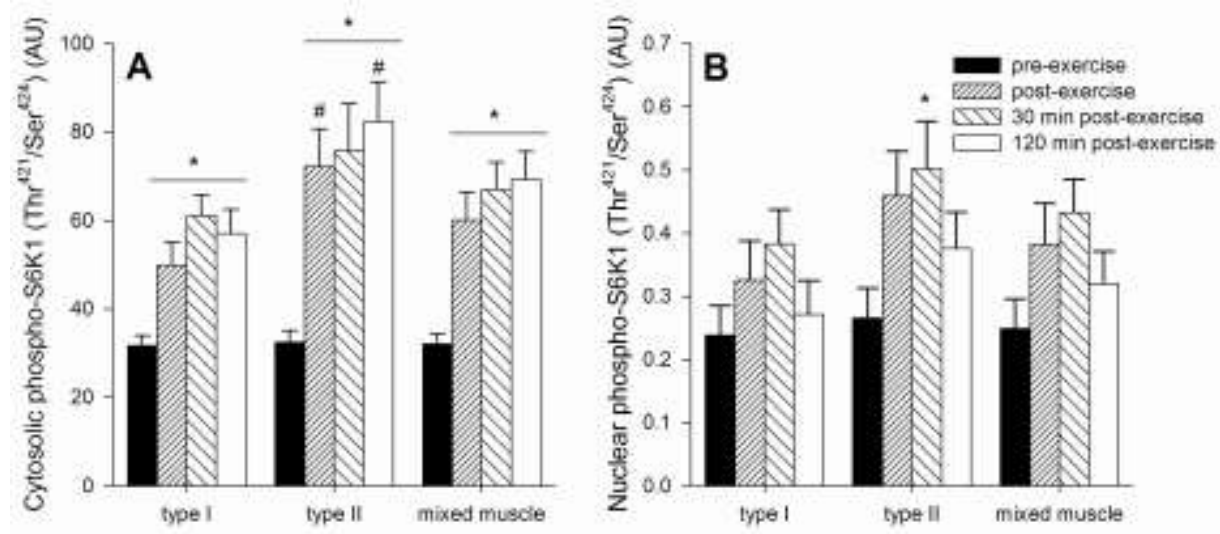

Figure 7.7 The effect of resistance exercise on the phosphorylation status of S6K1 in the cytosol (A) and nuclei (B). Mean fiber-type-specific intramyocellular phospho-S6K1 (expressed as staining intensity) and mean fibertype-specific nuclear phospho-p70/p85-S6K (expressed as \% area stained) before, immediately after exercise and following 30 and $120 \mathrm{~min}$ of post-exercise recovery as determined by fluorescence microscopy on stained muscle cross-sections. Data provided are means+SEM. * significantly different from pre-exercise values $(\mathrm{P}<0.05)$; \# significantly different from values observed in type I fibers $(\mathrm{P}<0.05)$.

Though the metabolic response to resistance exercise has not been studied extensively, it has been shown that muscle lactate concentrations quickly increase up to $\sim 17 \mathrm{mmol} \cdot \mathrm{kg}^{-1}$ wet muscle weight, during a single session of resistance exercise training in vivo in humans $(12,31)$. Furthermore, we observed that skeletal muscle fiber glycogen content declines substantially in both type I and II muscle fibers following resistance type exercise tasks (19). In line with these findings, we observed a marked increase in the phosphorylation of AMP-activated protein kinase (AMPK) in the present study (figure 7.1). This indicates that resistance exercise leads to a reduction in the energy status of the muscle fiber, thereby stimulating the phosphorylation of skeletal muscle AMPK. As far as we know, this is the first study to report an increase in AMPK phosphorylation following resistance type exercise activities. In accordance, earlier studies have reported that high-intensity endurance exercise $(6,37)$ but not low or moderate intensity exercise $(6,34)$ augments AMPK activation. The latter requires AMPK phosphorylation on $\mathrm{Thr}^{172}$ by an AMPK kinase. The major AMPK kinase in skeletal muscle is LKB1 (29). In addition, AMPK phosphorylation has been associated with the concomitant decline in muscle glycogen content, as AMPK has been suggested to have a glycogen-binding domain (29), which would explain the observation that AMPK is activated to a greater extent when muscle glycogen concentrations are low (37). Though AMPK is generally regarded as a main energy sensor in the cell, being responsible for the regulation of skeletal muscle glucose and fatty acid uptake and oxidation $(18,27)$, it was recently proposed that the AMP-activated protein kinase might also play an important role in the regulation of muscle protein synthesis and/or degradation $(4,7)$. 
Bolster and co-workers (4) were the first to show that AMPK activation in skeletal muscle tissue, by 5 -aminoimidazole-4-caroxamide 1- $\beta$-D-ribonucleoside (AICAR) administration in rats, reduces protein synthesis rates. The latter was associated with a reduced phosphorylation state of mTOR at $\mathrm{Ser}^{2448}$, S6K1 at $\mathrm{Thr}^{389}$ and 4EBP1 at $\mathrm{Thr}^{37}$ (4). More recently, it was proposed that activation of AMPK results in mTOR phosphorylation at $\mathrm{Thr}^{2446}(7)$, which decreases mTOR phosphorylation at Ser2448, thereby diminishing the ability of insulin (and other growth factors) to phosphorylate S6K1 (7). These observations are indicative of the presence of another metabolic master switch mechanism in which AMPK plays a key role by integrating signals associated with the energy state of the cell and growth factors associated with protein translation.

The present study shows that a single session of high-intensity resistance exercise in vivo in humans significantly increases AMPK phosphorylation and reduces the phosphorylation status of 4E-BP1 in skeletal muscle tissue immediately after cessation of exercise (figure 7.2). The exercise bout did not significantly increase S6 phosphorylation (figure 7.4), indicating that S6K1 activity was not substantially increased. The latter is in close agreement with observations in vitro in $\mathrm{H} 2 \mathrm{~K}$ myotubes (7) and in vivo in rats (4) showing AMPK phosphorylation to suppress S6K1 activity. The kinase activity of S6K1 is controlled by a series of phosphorylation steps at several Ser/Thr residues $(11,35)$. Phosphorylation of S6K1 in the carboxy terminal auto-inhibitory domain (at Ser ${ }^{411}, \mathrm{Ser}^{418}, \mathrm{Thr}^{421}$ and Ser ${ }^{424}$ ) results in a conformational change in the protein allowing the phosphorylation of $\mathrm{Ser}^{404}$, $\mathrm{Thr}^{389}$ in the linker domain and $\mathrm{Thr}^{229}$ in the catalytic domains, which activates the kinase $(27,35)$. Consequently, the ribosomal protein S6 on the 40S subunit is phosphorylated, which is thought to alter the interaction of the protein with the eIFs and the mRNA (7).

In the present study, we show that a single session of high-intensity resistance exercise was not sufficient to fully activate S6K1. The exercise effect of S6K1 was likely to be limited to $\mathrm{Thr}^{421} / \mathrm{Ser}^{424}$, as we did not observe a significant increase in the phosphorylation of S6. The extracellular signal-regulated kinase-1/2 (ERK $1 / 2)$ has been suggested to play an important role in phosphorylation of S6K1 on $\mathrm{Thr}^{421} / \mathrm{Ser}^{424}$. In accordance $\mathrm{ERK}_{1 / 2}$ phosphorylation has been shown to be substantially increased immediately following exercise $(16,24)$. Our observations are in agreement with data reported by Karlsson et al. (16), showing that a single session of resistance exercise (4 sets, 10 repetitions of leg extension) does not fully activate S6K1. However, they showed that post-exercise ingestion of branched chain amino acids has a striking effect on S6K1, which was evident by site-specific phosphorylation at $\mathrm{Thr}^{389}$ (16). These data indicate that intake of an ample amount of protein/amino acids is needed to fully activate skeletal muscle translation initiation. In contrast to these and our observations, there are some studies in rodents that have reported an increase in S6K1 activity in response to either isometric or eccentric contractions $(2,15,23)$. The apparent contradictory findings are attributed to the fact that maximal muscle contraction was induced through electrical stimulation of the nerve at $100 \mathrm{~Hz}$. The latter results in the recruitment of all motor units (including all fast and slow twitch fibers), which is quite different 
from voluntary muscle contraction in vivo (13). Therefore, in the present study we also aimed to study muscle fiber-type specific effects of resistance exercise on S6K1 phosphorylation.

Using immuno-histochemical techniques, we were able to quantify changes in phosphorylation of S6K1 at $\mathrm{Thr}^{421} / \mathrm{Ser}^{424}$ in a fiber-type specific manner. Phosphorylation of S6K1 was increased following resistance exercise in both the type I and type II fibers (figure 7.6). However, phosphorylation of S6K1 increased to a greater extent in the type II fibers compared to the type I fibers $(\mathrm{P}<0.05)$. In accordance, the phosphorylation of PKB (or Akt), mTOR and S6K1 following resistance exercise in rats has been reported to be more pronounced in muscle groups containing a greater proportion type II vs. type I muscle fibers (e.g. m. tibialis anterior vs. $\mathrm{m}$. soleus) $(2,25,28)$. Moreover, by the application of immunohistochemistry in rat $\mathrm{m}$. tibialis anterior, it has recently been shown that mTOR phosphorylation is selectively increased in type IIa fibers several hours after a bout of resistance exercise (25). These observations are most likely due to specificity in muscle fiber-type recruitment. Interestingly, we have recently shown that a single session of resistance exercise results in a substantial reduction in muscle fiber glycogen content. Moreover, these changes are fiber-type specific and are closely related to fiber-type oxidative capacity. As such, net changes in muscle fiber glycogen content were more pronounced in type II fibers compared to type I muscle fibers, which can be attributed to the greater recruitment of these fibers during high-intensity resistance exercise (13). One could, therefore, speculate that AMPK phosphorylation will increase to a greater extent in these fibers, phosphorylating mTOR on $\mathrm{Thr}^{2446}$, thereby decreasing the capacity of the kinase to phosphorylate S6K1 at $\mathrm{Thr}^{389}$. This could explain why we did not observe a substantial increase in $\mathrm{S} 6$ phosphorylation during the $2 \mathrm{~h}$ of post-exercise-recovery, while phosphorylation of S6K1 on $\mathrm{Thr}^{421} / \mathrm{Ser}^{424}$ was increased.

The localization of proteins involved in the regulation of translation initiation is thought to play an important role in the modulation of protein synthesis (17). Proteins like mTOR and S6K1 have been reported to be localized both in the cytosol as well as in the nuclei of human embryonic kidneys (HEK) 293 cells (17). Interestingly, it has been demonstrated that in vitro nuclear import of mTOR enhances 4E-BP1 phosphorylation and S6K1 activation, whereas nuclear export of mTOR attenuated the phosphorylation/activation, suggesting that both activation of S6K1 and phosphorylation of 4E-BP1 require nuclear mTOR (17). Similar nuclear transport has also been reported for S6K1 (17). In the light of these observations, the present study also examined the sub-cellular location of S6K1, using immuno-fluorescence staining of the muscle membrane, nuclei and S6K1 $\left(\mathrm{Thr}^{421} / \mathrm{Ser}^{424}\right)$. In the pre-exercise muscle biopsies we show a predominant nuclear localization of phospho-S6K1 (figure 7.5, 7.6 A/C), while following the resistance exercise session, phosphorylated S6K1 is primarily located in the cytosol (figure 7.6 $\mathrm{B} / \mathrm{D})$, especially in type II fibers. Interestingly, we show that 30 min after cessation of exercise nuclear phospho-S6K1 content was increased in the type II fibers. The latter could imply that the nucleus plays a key role in the activation of S6K1 and/or that S6K1 functions as a transcription factor. However, as the antibody 
that was used recognizes both p70 and p85-S6K, we cannot differentiate between nuclear import of S6K1 and phosphorylation of p85-S6K, the latter of which is known for its unique nuclear localization $(10,21)$. More research is warranted to determine the role of sub-cellular location of S6K1 and its potential regulatory role.

We conclude that a single bout of resistance exercise in vivo in humans activates skeletal muscle AMPK, resulting in a decrease in the phosphorylation state of 4EBP1. During recovery S6K1 phosphorylation is increased, and showed to be fibertype specific, indicating that the signaling response to S6K1 is muscle fiber-type specific. However, in the absence of food intake, the phosphorylation status of S6K1 on $\mathrm{Thr}^{421} / \mathrm{Ser}^{424}$ is not accompanied by a substantial increase in the phosphorylation of S6 under fasting conditions. As such, in the absence of food intake, exercise does not fully activate the translation initiation process in skeletal muscle tissue.

\section{Acknowledgements}

We gratefully acknowledge the enthusiastic support of the subjects who volunteered to participate in these trials. The monoclonal antibody A4.951 developed by Dr. Blau was obtained from the Developmental Studies Hybridoma Bank developed under the auspices of the NICHD and maintained by the University of Iowa, Department of Biological Science, Iowa City, IA 52242, USA. 


\section{References}

1. Anthony JC, Anthony TG, Kimball SR, and Jefferson LS. Signaling pathways involved in translational control of protein synthesis in skeletal muscle by leucine. J Nutr 131: 856S-860S, 2001.

2. Baar K and Esser K. Phosphorylation of p70(S6k) correlates with increased skeletal muscle mass following resistance exercise. Am J Physiol 276: C120-127, 1999.

3. Bergstrom J. Percutaneous needle biopsy of skeletal muscle in physiological and clinical research. Scand J Clin Lab Invest 35: 609-616, 1975.

4. Bolster DR, Crozier SJ, Kimball SR, and Jefferson LS. AMP-activated protein kinase suppresses protein synthesis in rat skeletal muscle through downregulated mTOR signaling. J Biol Chem 277: 23977-23980, 2002.

5. Bolster DR, Kimball SR, and Jefferson LS. Translational control mechanisms modulate skeletal muscle gene expression during hypertrophy. Exerc Sport Sci Rev 31: 111-116, 2003.

6. Chen ZP, Stephens TJ, Murthy S, Canny BJ, Hargreaves M, Witters LA, Kemp BE, and McConell GK. Effect of exercise intensity on skeletal muscle AMPK signaling in humans. Diabetes 52: 2205-2212, 2003.

7. Cheng SW, Fryer LG, Carling D, and Shepherd PR. Thr2446 is a novel mammalian target of rapamycin (mTOR) phosphorylation site regulated by nutrient status. J Biol Chem 279: 15719-15722, 2004.

8. Chesley A, MacDougall JD, Tarnopolsky MA, Atkinson SA, and Smith K. Changes in human muscle protein synthesis after resistance exercise. J Appl Physiol 73: 1383-1388, 1992.

9. Cuthbertson D, Smith K, Babraj J, Leese G, Waddell T, Atherton P, Wackerhage H, Taylor PM, and Rennie MJ. Anabolic signaling deficits underlie amino acid resistance of wasting, aging muscle. Faseb J 19: 422-424, 2005.

10. Dennis PB, Pullen N, Kozma SC, and Thomas G. The principal rapamycin-sensitive p70(s6k) phosphorylation sites, T-229 and T-389, are differentially regulated by rapamycin-insensitive kinase kinases. Mol Cell Biol 16: 6242-6251, 1996.

11. Dufner A and Thomas G. Ribosomal S6 kinase signaling and the control of translation. Exp Cell Res 253: 100-109, 1999.

12. Essen-Gustavsson B and Tesch PA. Glycogen and triglyceride utilization in relation to muscle metabolic characteristics in men performing heavy-resistance exercise. Eur J Appl Physiol Occup Physiol 61: 5-10, 1990.

13. Fry AC. The role of resistance exercise intensity on muscle fibre adaptations. Sports Med 34: 663-679, 2004.

14. Gingras AC, Raught B, and Sonenberg N. eIF4 initiation factors: effectors of mRNA recruitment to ribosomes and regulators of translation. Annu Rev Biochem 68: 913 963, 1999.

15. Haddad F and Adams GR. Selected contribution: acute cellular and molecular responses to resistance exercise. J Appl Physiol 93: 394-403, 2002.

16. Karlsson HK, Nilsson PA, Nilsson J, Chibalin AV, Zierath JR, and Blomstrand E. Branched-Chain Amino Acids Increase p70S6 Kinase Phosphorylation in Human Skeletal Muscle after Resistance Exercise. Am J Physiol Endocrinol Metab, 2004.

17. Kim JE and Chen J. Cytoplasmic-nuclear shuttling of FKBP12-rapamycin-associated protein is involved in rapamycin-sensitive signaling and translation initiation. Proc Natl Acad Sci U S A 97: 14340-14345, 2000. 
18. Kimball SR, Farrell PA, and Jefferson LS. Invited Review: Role of insulin in translational control of protein synthesis in skeletal muscle by amino acids or exercise. J Appl Physiol 93: 1168-1180, 2002.

19. Koopman R, Manders RJ, Jonkers RA, Hul GB, Kuipers H, and van Loon LJ. Intramyocellular lipid and glycogen content are reduced following resistance exercise in untrained healthy males. Eur J Appl Physiol 96: 525-534, 2006.

20. Kraemer WJ and Fry AC. Strength Testing; Development and Evaluation of Methodology. In: Physiological Assesment of Human Fitness, edited by Maud PJ and Foster C. Leeds: Human Kinetics, 1995, p. 115-133.

21. Laser M, Kasi VS, Hamawaki M, Cooper Gt, Kerr CM, and Kuppuswamy D. Differential activation of p70 and p85 S6 kinase isoforms during cardiac hypertrophy in the adult mammal. J Biol Chem 273: 24610-24619, 1998.

22. Mayhew JL, Prinster JL, Ware JS, Zimmer DL, Arabas JR, and Bemben MG. Muscular endurance repetitions to predict bench press strength in men of different training levels. J Sports Med Phys Fitness 35: 108-113, 1995.

23. Nader GA and Esser KA. Intracellular signaling specificity in skeletal muscle in response to different modes of exercise. J Appl Physiol 90: 1936-1942, 2001.

24. Parkington JD, LeBrasseur NK, Siebert AP, and Fielding RA. Contraction-mediated mTOR, p70S6k, and ERK1/2 phosphorylation in aged skeletal muscle. J Appl Physiol 97: 243-248, 2004.

25. Parkington JD, Siebert AP, LeBrasseur NK, and Fielding RA. Differential activation of mTOR signaling by contractile activity in skeletal muscle. Am J Physiol Regul Integr Comp Physiol 285: R1086-1090, 2003.

26. Phillips SM, Tipton KD, Aarsland A, Wolf SE, and Wolfe RR. Mixed muscle protein synthesis and breakdown after resistance exercise in humans. Am J Physiol 273: E99107, 1997.

27. Pullen $\mathrm{N}$ and Thomas G. The modular phosphorylation and activation of p70s6k. FEBS Lett 410: 78-82, 1997.

28. Sakamoto K, Aschenbach WG, Hirshman MF, and Goodyear LJ. Akt signaling in skeletal muscle: regulation by exercise and passive stretch. Am J Physiol Endocrinol Metab 285: E1081-1088, 2003.

29. Sakamoto K, Goransson O, Hardie DG, and Alessi DR. Activity of LKB1 and AMPK-related kinases in skeletal muscle: effects of contraction, phenformin, and AICAR. Am J Physiol Endocrinol Metab 287: E310-317, 2004.

30. Siri WE. The gross composition of the body. Adv Biol Med Physiol 4: 238-280, 1956.

31. Tesch PA, Colliander EB, and Kaiser P. Muscle metabolism during intense, heavyresistance exercise. Eur J Appl Physiol Occup Physiol 55: 362-366, 1986.

32. Trappe TA, Raue U, and Tesch PA. Human soleus muscle protein synthesis following resistance exercise. Acta Physiol Scand 182: 189-196, 2004.

33. van Loon LJ, Koopman R, Manders R, van der Weegen W, van Kranenburg GP, and Keizer HA. Intramyocellular lipid content in type 2 diabetes patients compared with overweight sedentary men and highly trained endurance athletes. Am J Physiol Endocrinol Metab 287: E558-565, 2004.

34. van Loon LJ, Thomason-Hughes M, Constantin-Teodosiu D, Koopman R, Greenhaff PL, Hardie DG, Keizer HA, Saris WH, and Wagenmakers AJ. Inhibition of adipose tissue lipolysis increases intramuscular lipid and glycogen use in vivo in humans. Am J Physiol Endocrinol Metab 289: E482-493, 2005.

35. Weng QP, Kozlowski M, Belham C, Zhang A, Comb MJ, and Avruch J. Regulation of the p70 S6 kinase by phosphorylation in vivo. Analysis using site-specific antiphosphopeptide antibodies. J Biol Chem 273: 16621-16629, 1998. 
36. Withers DJ, Ouwens DM, Nave BT, van der Zon GC, Alarcon CM, Cardenas ME, Heitman J, Maassen JA, and Shepherd PR. Expression, enzyme activity, and subcellular localization of mammalian target of rapamycin in insulin-responsive cells. Biochem Biophys Res Commun 241: 704-709, 1997.

37. Wojtaszewski JF, MacDonald C, Nielsen JN, Hellsten Y, Hardie DG, Kemp BE, Kiens B, and Richter EA. Regulation of 5'AMP-activated protein kinase activity and substrate utilization in exercising human skeletal muscle. Am J Physiol Endocrinol Metab 284: E813-822, 2003. 



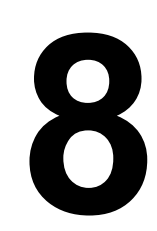

General Discussion 
Skeletal muscle plays a central role in the regulation of whole-body glucose metabolism. By virtue of its mass, skeletal muscle is the primary tissue responsible for insulin-dependent glucose clearance, accounting for up to $80 \%$ of whole-body glucose uptake after meal ingestion. In addition, the total amount of muscle mass is also one of the main determinants of basal metabolic rate (BMR). Aging is accompanied with a substantial loss of muscle mass, which consequently leads to muscle weakness and major disabilities in every day life. The latter is accompanied by a reduction in BMR, the loss of functional capacity and an increased likelihood of developing chronic metabolic diseases like obesity, type 2 diabetes and osteoporosis.

Various interventions have been proposed to reduce or reverse the loss of muscle mass and function. It has been suggested that physical activity (i.e. resistance exercise) and nutritional interventions (i.e. protein, amino acids) could represent effective strategies to reduce, or counteract the loss of muscle tissue that occurs with aging and disease. In this thesis we focus on the beneficial effects of resistance exercise and the potential of dietary supplementation with carbohydrate, protein and/or specific amino acids to enhance muscle protein anabolism. In chapter 2 we first show that resistance exercise is as powerful as endurance exercise in enhancing post-exercise insulin sensitivity. Both the amount of lipid and glycogen stored in muscle have been shown to play a role in the exercise induced increase in muscle insulin sensitivity. We, therefore, have investigated the use of intramuscular lipid and glycogen stores during resistance exercise in chapter 3. In chapter 4-6 the use of insulinotropic protein/amino acid mixtures to accelerate post-exercise (total muscle) protein synthesis has been investigated. In chapter 7, we looked at changes in the phosphorylation of 4E-BP1 and S6K1 following resistance exercise to get a better understanding of the upregulation of the molecular signaling mechanisms that control muscle protein synthesis.

In this final chapter, we will elaborate on some of the reported findings by discussing their significance and clinical relevance in the elderly population. In addition, we will discuss specific methodological issues that need to be considered in future studies. In the last paragraph, important aims for future research will be defined.

\section{Resistance exercise and insulin sensitivity}

Most exercise intervention programs solely use endurance exercise because of its acute enhancing effect on insulin stimulated glucose clearance. Interestingly, we have shown that a single bout of resistance exercise also improves whole-body insulin sensitivity by $\sim 15 \%$ when measured $24 \mathrm{~h}$ after cessation of exercise (chapter 2 ). This seems to be of a similar magnitude as the $\sim 20 \%$ improvement that has been reported following an acute ( $\sim 60 \mathrm{~min})$ bout of endurance exercise $(51,59)$. As such, there should be no restriction in combining the benefits of both types of exercise in future lifestyle intervention programs. This could be of significant importance in frail and/or type 2 diabetic elderly, who are often in such a physical 
state that generally does not allow them to perform endurance exercise. In that case, it would be helpful to first gain muscle strength and mass through resistance training.

The mechanisms by which resistance exercise stimulates insulin sensitivity have not yet been fully elucidated. It seems likely to assume that resistance exercise is followed by an attenuated muscle GLUT-4 translocation (78) and/or elevated GLUT-4 expression (45). Factors thought to play a major regulatory role in this process include AMPK activation $(26,28,35,101), \mathrm{Ca}^{2+} /$ calmodulin-dependent kinases $(108,109)$, muscle glycogen content and subsequent activation of glycogen synthase activity $(11,23,29,55,59,102,103)$. Prolonged moderate intensity endurance exercise does not seem to increase AMPK phosphorylation $(20,90)$ and does not affect signaling through the insulin signaling pathway (102). The latter is evidenced by unchanged phosphorylation of insulin receptor tyrosine kinase, Akt and GSK-3 (102). It is therefore thought that activation of $\mathrm{Ca}^{2+} /$ calmodulindependent kinases $(22,68)$ and the reduction in muscle glycogen content and subsequent activation of glycogen synthase are the main regulatory factors that modulate glucose uptake following endurance exercise (55). Interestingly, in contrast to moderate intensity endurance exercise, resistance exercise has been reported to lead to an increase in AMPK phosphorylation (chapter 7) and to activate signaling through the PI-3 kinase/mTOR pathway (36). Prolonged (1624h) activation of PI-3 kinase, and several downstream effectors like S6K1 (36, 46), 4E-BP1 (46) and S6 (46) have been reported in rat skeletal muscle following resistance exercise (36). The reported activation of the PI-3 kinase/mTOR pathway is likely to play an important role in the augmented glucose uptake and protein synthesis rates following resistance exercise. Increased Akt signaling has been shown to inhibit GSK3, which leads to the activation of glycogen synthase and to GLUT4 translocation (71). In addition, resistance exercise can also substantially reduce muscle glycogen content (chapter $3,(24,77)$ ). This implies that resistance exercise has the ability to enhance muscle insulin sensitivity via several other potential mechanisms and might therefore represent a more powerful means to increase the blood glucose clearance capacity when compared to endurance exercise (18).

In contrast to endurance exercise, information on the metabolic demands imposed upon by resistance exercise (i.e. muscle glycogen and IMTG utilization) is scarce. Early reports suggested that the energy needs during resistance exercise are provided with only a minimal activation of glycogenolysis or lipolysis (39). In chapter 3 we, therefore, investigated fiber-type specific changes in skeletal muscle glycogen and lipid content following resistance exercise and subsequent recovery using histological techniques. The use of (immuno)histochemistry on skeletal muscle cross-sections prepared from muscle biopsy samples represent an effective strategy to assess fiber-type specific changes in intramyocellular lipid and/or glycogen content, without the methodological limitations generally associated with biochemical extraction analyses on skeletal muscle samples, like the contamination of skeletal muscle tissue with extramyocellular fat (37). In 2001, we introduced an optimized lipid staining protocol, permitting automated quantification of 
intramyocellular lipid depositions in skeletal muscle sections together with immuno-localization of other myocellular elements by fluorescence microscopy. Lipid droplets were detected in skeletal muscle by oil red O (ORO) staining, which was modified to diminish background staining, to prevent crystallization of ORO and to optimize lipid retention in cryosections (43). Since then we have implemented this method in several studies to investigate the effects of exercise and dietary interventions on muscle fiber-type specific lipid content $(85,87,89$, 90). Moreover, we recently reported a good correlation between IMTG content as determined by ${ }^{1} \mathrm{H}$-magnetic resonance spectroscopy (MRS) and fluorescence microscopy (86). The conventional periodic acid-Schiff reagent (PAS) reaction to stain for muscle glycogen content has been optimized in a similar manner as the oil red $\mathrm{O}$ staining (74). Strong correlations between data on (mixed-muscle) glycogen content obtained by the use of both biochemical and histochemical methods have recently been reported (74). These observations indicate that semi-quantitative microscopy on PAS or ORO-stained muscle cross-sections represent valid methods to determine fiber-type-specific changes in muscle glycogen and lipid content and can be used to create insight in differences between fuel storage between the different muscle fiber-types and, as such, in their subsequent role in skeletal muscle metabolism.

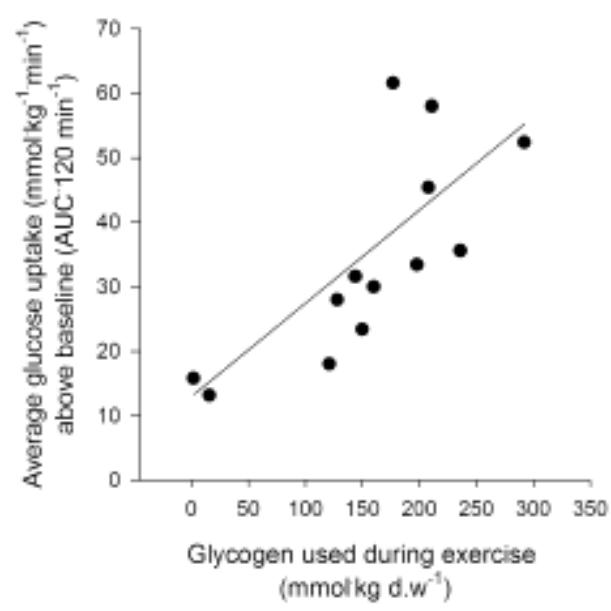

Figure 8.1 Correlation between the degree of glycogen depletion and the insulin-stimulated glucose uptake in thigh muscles of healthy men. Adapted from Richter et al. (66).

The applied methodology clearly shows that mixed muscle glycogen content is substantially decreased following resistance exercise, which is in line with previous studies applying biochemical analysis on mixed muscle tissue $(24,77)$. We extend on the earlier findings by showing that these changes in muscle glycogen content are fiber-type specific, and more pronounced in type IIx fibers when compared to type I muscle fibers. This is in contrast to observations following endurance 
exercise, where glycogen stores are primarily reduced in type I fibers (unpublished observations, L. van Loon \& R. Koopman). This apparent difference may be the result of the high rate of ATP production per second necessary to sustain the high power output during resistance exercise in type II fibers. Due to the observed low mitochondrial content in type IIx fibers, they must rely for the greater part on anaerobic glycogenolysis for ATP generation.

The exercise-induced reduction in skeletal muscle glycogen content has been associated with an increase in insulin sensitivity $(11,59,102,103)$ as shown in figure 8.1. In fact, skeletal muscle glucose uptake and glycogen synthase activity have been shown to strongly depend on muscle glycogen availability $(56,104)$. Interestingly, not only muscle substrate utilization has been shown to be fiber-type specific. AMPK activation, induced by AICAR, increases glucose uptake in rat fast-twitch muscle (109), but not in slow twitch soleus muscle (108). There are also indications that the activation of the insulin signaling cascade following resistance exercise is fiber-type specific. In chapter 7, we show that S6K1 phosphorylation following resistance exercise in humans is more pronounced in type II, compared to type I muscle fibers. In addition, the phosphorylation of PKB (or Akt), mTOR and S6K1 following resistance exercise in rats has been reported to be more pronounced in muscle tissue containing a greater proportion of type II muscle fibers $(5,58,70)$, as opposed to those muscle groups containing more type I fibers (58). Moreover, by applying immunohistochemistry in rat tibialis muscle, it was recently shown that mTOR phosphorylation is selectively increased in type IIa fibers for up to several $\mathrm{h}$ after resistance exercise (58). This selective activation of the signaling through mTOR in fast-twitch muscle fibers may in part explain why endurance exercise, in contrast to resistance exercise, does not affect signaling through the insulin signaling pathway.

We have recently demonstrated a substantial $(\sim 60 \%)$ net reduction in type I muscle fiber lipid content following $2 \mathrm{~h}$ of moderate intensity endurance exercise $(86,90)$. Moreover, it has been reported that it takes $\sim 48 \mathrm{~h}$ to fully replenish the IMTG stores following a $3 \mathrm{~h}$ endurance exercise bout (89). Interestingly, in chapter 3 we report a net decline $(\sim 27 \%)$ in IMTG content following resistance exercise in type I muscle fibers. Nevertheless, this effect was only temporary and not evident after $2 \mathrm{~h}$ of post-exercise recovery. The absence of a prolonged net reduction in skeletal muscle lipid content implies that the reported stimulating effects of resistance exercise on whole-body insulin sensitivity are unlikely to be attributed to a reduction in intramuscular lipid content. However, it has been suggested that not IMTG content per se, but fatty acid intermediates like fatty acyl-CoA, ceramides and/or diacylglycerol modulate skeletal muscle insulin signaling. Increased intracellular concentrations of such fatty acid intermediates have been shown to increase PKC activation and enhance serine phosphorylation of the insulin receptor substrate-1 (IRS-1). The latter reduces its tyrosine phosphorylation, thereby suppressing PI-3 kinase activity, leading to a reduced GLUT-4 translocation to the sarcolemma. It could be speculated that acute changes in muscle fatty acyl-CoA, ceramides and diacylglycerol concentrations following resistance exercise are (partly) responsible for the observed effects of resistance 
training on skeletal muscle insulin sensitivity $(84,85)$. However, more research is warranted to address the proposed relationship between exercise, fatty acid intermediates and skeletal muscle insulin sensitivity.

\section{Nutritional interventions to promote muscle protein synthesis}

Endurance athletes optimize carbohydrate availability before, during and after prolonged endurance exercise to replenish muscle and liver glycogen stores and, as such, to optimize endurance performance capacity. In addition, it has been suggested that the ingestion of carbohydrate reduces protein degradation (69). In line with these findings, we demonstrate in chapter 4 that net protein degradation does not increase during moderate intensity endurance exercise when carbohydrate is ingested. This implies that net protein breakdown and oxidation is of minor magnitude during endurance type activities, like (ultra)marathons and prolonged cycling races. However, when only carbohydrate is ingested during and after exercise, whole-body protein balance remains slightly negative during exercise and subsequent recovery (42). The latter indicates that the ingestion of protein/amino acids is needed to obtain a positive net protein balance. In accordance, we show that the combined ingestion of protein and carbohydrate improves net protein balance at rest, during prolonged moderate intensity exercise and subsequent recovery in elite endurance athletes. The latter may well play an important role in the facilitation of specific muscle adaptation following endurance exercise training. Specific muscle adaptation includes the increased expression of proteins instrumental in the processes involved in the mobilization and oxidation of endogenous fat and carbohydrate stores.

\section{Optimizing protein metabolism following resistance exercise}

In contrast to endurance exercise, resistance exercise training can result in profound increases in skeletal muscle mass and strength $(25,67,99)$. Interestingly, after a single session of resistance exercise, both muscle protein synthesis and degradation rates are strongly elevated (60). As a result, net muscle protein balance will remain negative in the absence of food intake. The latter implies that skeletal muscle hypertrophy can only occur under conditions where food is ingested during the early phases of post-exercise recovery. Therefore, the combined ingestion of protein and carbohydrate represents an effective strategy to promote net muscle protein accretion, as it can stimulate protein metabolism in several ways. Besides providing amino acids as precursors for protein synthesis, combined ingestion of carbohydrate and protein/amino acids has been shown to elevate plasma insulin levels $(41,46,63,65,66)$, which could further augment protein anabolism $(6,10$, $27,31,32)$. Interestingly, a growing body of evidence indicates that amino acids can also function as potent nutritional signaling molecules, with an active regulatory function in muscle protein metabolism. It has been suggested that all essential amino acids (EAA) are responsible for the amino acid induced stimulation of muscle protein synthesis (92). Their presence stimulates protein synthesis, most 
likely through stimulation of multiple steps in the mRNA translation process $(3,4)$. The branched-chain amino acids (30), and leucine in particular $(3,4)$, seem to have the highest potential to promote protein anabolism, by decreasing the rate of protein degradation and increasing muscle protein synthesis rates (54). The latter could partly be attributed to the insulinotropic potential of leucine, and the subsequent phosphorylation of key regulatory proteins that modulate protein synthesis $(38,48,62)$. However, the anabolic effects of leucine have also been reported in the absence of elevated insulin concentrations. As such, leucine seems to be able to stimulate skeletal muscle protein synthesis through both insulindependent as well as insulin-independent mechanisms (3), which involve signaling through the mammalian target of rapamycin or mTOR (41). Despite many speculations and promising results from recent animal studies, there is hardly any evidence showing leucine supplementation to improve protein balance in vivo in humans.

Therefore, in chapter 5 and 6 we have investigated the potential of co-ingestion of leucine and protein with carbohydrate following resistance exercise or activities of daily living (ADL) to stimulate protein anabolism. Co-ingestion of leucine resulted in lower whole-body protein breakdown and oxidation rates and increased protein synthesis. The latter could partly be attributed to the higher plasma insulin concentrations following leucine co-ingestion. In line with previous studies $(47,52$, 64), we showed that net protein balance can be improved by the ingestion of protein and carbohydrate in the post-exercise/ADL period. Moreover, in chapter 5 we have shown that the co-ingestion of leucine and protein with carbohydrate following resistance exercise resulted in higher muscle protein synthesis rates, compared to the ingestion of carbohydrate only. In addition, a greater whole-body protein balance was observed when compared to the ingestion of carbohydrate only and carbohydrate with protein (44). Nonetheless, muscle protein synthesis rates were similar with and without leucine when added to protein and carbohydrate. Although this study does not clearly demonstrate that leucine stimulates muscle protein synthesis in vivo in humans following resistance exercise, it demonstrates that protein anabolism following resistance exercise can be augmented with the ingestion of the leucine, protein and carbohydrate mixture. As there is an overwhelming interest in the effects of leucine on muscle protein metabolism, numerous studies have been performed to investigate the pathways involved in (amino acid induced) protein synthesis and degradation. With the identification of leucine as a potent nutritional signaling molecule, most studies have focused on the effects of leucine to modulate these signaling events. However, it would be naive to assume that the regulatory role of leucine in protein metabolism is unique. Even though leucine seems to be most effective in stimulating protein anabolism (17), we hypothesize that most essential amino acids are likely to play a regulatory role in protein metabolism and that these are likely to be mutually synergistic in stimulating protein anabolism. Future research should define the most important essential amino acids with such a regulatory potential. 


\section{Optimizing protein anabolism in the elderly}

Aging is associated with the progressive decline in skeletal muscle mass and function. The age-related changes in skeletal muscle mass are attributed to a disturbance in the regulation of muscle protein turnover, which results in a chronic imbalance between muscle protein synthesis and degradation. In chapter 6, we investigated the anabolic response to carbohydrate $(\mathrm{CHO})$ ingestion following simulated ADL type activities in vivo in young $(\sim 20 \mathrm{y})$ and elderly men $(\sim 75 \mathrm{y})$. Consequently, we show that muscle protein synthesis rates are significantly lower in the elderly $(\sim 75 \mathrm{y})$ compared with the young $(\sim 20 \mathrm{y})$ under such conditions. The observed mixed muscle fractional synthetic rate (FSR) values following ADL activities were $\sim 30 \%$ lower in the elderly compared with the young subjects. These observations are similar to previous reports showing muscle protein synthesis rates to be $20-30 \%$ lower in elderly humans (60-84 yrs) than in young adults in a basal, fasted state $(34,75,100)$. Our findings on the muscle level are in line with our observations using the whole-body tracer methods showing whole-body phenylalanine and tyrosine turnover to be $20-25 \%$ lower in the elderly compared with the young. Thus, on a whole-body level, protein synthesis, oxidation and breakdown are reduced in the elderly compared with the young subjects. The reduction in whole-body protein turnover may indicate that tissue remodeling is impaired in the elderly. Muscle tissue remodeling, which involves the up- and/or down-regulation of specific sets of proteins $(72,73)$, is necessary to optimize muscle function for a new type of activity. The lower protein turnover rate in the elderly could indicate that the adaptive response to training is impaired. Consequently, it would be interesting to investigate whether there are differences in the specific sets of proteins that are up and/or down-regulated after exercise in young and elderly humans.

In accordance to our earlier findings (44), we observed that whole-body net protein balance remains negative when only carbohydrate is ingested. To our knowledge we are the first to show that muscle protein synthesis is reduced in the elderly under practical daily living conditions in which ADL activities are followed by ingestion of carbohydrate only. Interestingly, co-ingestion of protein and leucine stimulates muscle protein synthesis rates to the same extent in young and elderly men (chapter 6). This is in line with more recent observations, showing a similar response of muscle protein turnover to an amino acid load in healthy elderly and younger adults $(57,91,94)$. However, our FSR data seem to be quite the opposite from data presented by Volpi et al (93), who showed that the response of muscle protein synthesis to the combined ingestion of amino acids and glucose is impaired in the elderly. The latter could be related to the blunted insulin response in the elderly compared with the young controls that were reported by Volpi et al (93). In contrast, we excluded subjects with impaired insulin sensitivity/glucose tolerance and we observed similar plasma insulin responses in the young and elderly volunteers following the co-ingestion of protein and leucine with carbohydrate. The observed differences might be attributed to the property of leucine to stimulate insulin secretion (88) and/or mRNA translation (2). In this study, we investigated the potential differences in the capacity to stimulate muscle 
protein synthesis in the young and elderly following the ingestion of a theoretically optimal anabolic nutritional intervention strategy. The latter shows that the response to the intervention is of a similar magnitude in the young and elderly. However, our study does not demonstrate that leucine stimulates muscle protein synthesis in vivo in elderly humans. Whether additional leucine ingestion is more effective in promoting muscle anabolism than protein and carbohydrate only remains to be established in the elderly population. The latter will be addressed in one of our future studies.

\section{Amino acids tracer considerations}

Stable isotope amino acid tracers are widely used to study protein metabolism (96). With the continuous intravenous infusion of these tracers, and repeated sampling from the plasma pool, whole-body amino acid kinetics can be determined (i.e. the rate of appearance $(\mathrm{Ra})$ and the rate of disappearance $(\mathrm{Rd})$ of the amino acid of interest). In this model amino acid Rd from the blood compartment equals the rate of oxidation + protein synthesis, whereas amino acid Ra equals the rate of protein breakdown + the rate of appearance of amino acids from dietary protein from the gut (105).

The use of the (whole-body) tracer balance methodology to investigate the effect of post-exercise nutrition on protein metabolism has some important limitations as it is based on a few important assumptions. Two important assumptions include: 1) tissue amino acid pool size and enrichment are constant and 2) the amino acid tracer used is representative for the metabolism of the other amino acids. The first assumption indicates that the whole-body method (or any other compartmental analyses) is only valid when a steady state is present in the concentration and enrichment of the tracer amino acid in the plasma and muscle pool. However, after the oral ingestion of amino acids, it has been shown that amino acid concentrations increase substantially in the muscle free amino acid pool (15). The latter indicates that a significant portion of the plasma amino acid $\mathrm{Rd}$ results in muscle amino acid pool extension. This results in an overestimation of whole-body protein synthesis rates. Consequently, methods were introduced to measure tissue or protein-specific synthesis rates. In chapter 5 and 6 , we have measured tracer incorporation in muscle protein as a means to directly measure mixed muscle protein synthesis rates.

The second assumption indicates that the whole-body method can only provide useful information upon whole-body protein turnover, when the applied amino acid tracer is a valid representative for the metabolic fate of all other amino acids. In early amino acid tracer studies, leucine was generally applied as a tracer $(49,53$, $65,76,100,106,107)$. However, in chapter 4 we stress that care should be taken with the use of the leucine tracer to study protein metabolism during exercise. Leucine metabolism during exercise is not generally representative of the fate of the other amino acids that are present in proteins. During exercise, uptake $(1,82)$ and oxidation $(82,97,98)$ of branched chain amino acids (leucine, isoleucine and valine) increase several fold in contracting muscle. The latter means that the 
stochastic leucine model of whole-body protein metabolism (50) becomes invalid during exercise and cannot be used to estimate qualitative or quantitative changes in whole-body protein synthesis and/or degradation. Therefore, more recent studies from our $(42,44)$ and other laboratories $(12,60,64,80,95)$ have used phenylalanine as a tracer to study protein metabolism. It has been shown that phenylalanine is not oxidized in rat skeletal muscle (19), which would mean that all phenylalanine that enters the muscle is used for muscle protein synthesis (7). This is one of the other basic assumptions of the three compartment model as proposed by Biolo et al (7). Interestingly, in chapters 5 and 6 we provide data that tend to proof this assumption wrong. In these chapters we infused labeled phenylalanine and measured phenylalanine and tyrosine enrichment in plasma and free muscle amino acid pool. Consequently, we observed $\sim 60 \%$ higher tyrosine enrichments in the free muscle amino acid pool compared to values observed in plasma. This seems to suggest that phenylalanine is converted to tyrosine in skeletal muscle. The latter is in line with observations by van Hall et al. (83), showing that during one-legged exercise, tyrosine is released from the muscle in larger amounts than its relative occurrence in muscle protein and phenylalanine in smaller amounts. These and our findings may have major implications for the published data to date, as most tracer models are based on the assumption that phenylalanine is not broken down in the muscle. Consequently, these studies are likely overestimating muscle protein synthesis, and care should be taken with the interpretation of these data. The latter will be investigated in detail in future studies.

\section{Regulation of protein synthesis: effects of exercise and nutrition}

It has been shown that both muscle protein synthesis $(8,60,79)$ as well as protein breakdown rates $(8,60)$ are accelerated following resistance exercise. Resistance exercise exerts its effect either via the increased local production of muscle specific IGF-1 or MGF (33) and/or other contraction induced signaling events. These factors can increase signaling of the PI-3 kinase/mTOR pathway resulting in an increase in muscle protein synthesis rates and glucose uptake. However, food intake is an essential factor to fully stimulate the activity of this signaling pathway. Although muscle protein synthesis is stimulated during the post-exercise recovery phase (60), net muscle protein balance remains negative in the absence of food intake $(8,60,61)$. It has been shown that the administration of protein/amino acids with carbohydrate results in a rapid increase in muscle protein synthesis rates (chapter 5 and 6), whereas (whole-body) protein degradation rates are decreased ( 9 , $15,64,79,81)$.

Recent evidence suggests that the phosphatidylisositol 3-kinase (PI3-K) signaling pathway plays a key role in the integration of contraction mediated signaling (for example MGF) and signaling from nutritional factors $(40,70)$. The activity of the signaling cascade controlling muscle protein synthesis is largely determined by the phosphorylation of the mammalian target of rapamycin (mTOR) and its subsequent activation of the $70-\mathrm{kDa} \mathrm{S} 6$ protein kinase $(\mathrm{p} 70-\mathrm{S} 6 \mathrm{~K})$ and the 
eukaryotic initiation factor 4E-binding protein (4E-BP1) (40). In chapter 7, we report a marked increase in the phosphorylation of AMP-activated protein kinase (AMPK), indicating that resistance exercise leads to a reduction in the energy status of the muscle fiber, thereby stimulating the phosphorylation of skeletal muscle AMPK. AMPK activation in skeletal muscle tissue has been associated with a reduced phosphorylation state of mTOR at Ser ${ }^{2448}$, p70-S6K at $\mathrm{Thr}^{389}$ and 4E-BP1 at $\mathrm{Thr}^{37}$ (13). More recently, it was proposed that activation of AMPK results in m'TOR phosphorylation at $\operatorname{Thr}^{2446}(21)$, which decreases mTOR phosphorylation at $\operatorname{Ser}^{2448}$ (figure 8.2), thereby diminishing the ability of insulin (and other growth factors) to phosphorylate p70-S6K (21) during exercise. These observations are indicative of the presence of a metabolic switch mechanism in which AMPK plays a key role by integrating signals associated with the energy state of the cell and growth factors associated with protein translation.

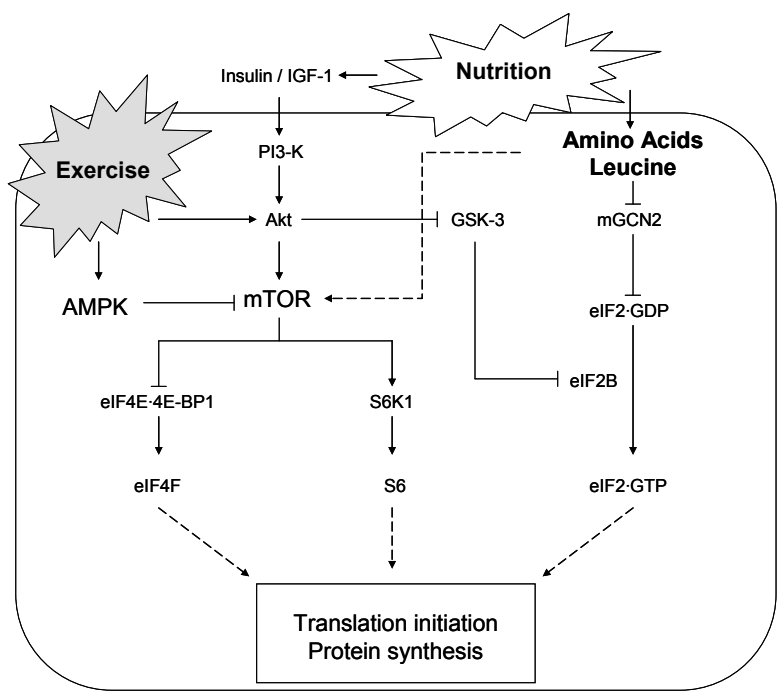

Figure 8.2 The integration of signals from exercise and nutritional factors. PI3-K, phosphatidylinositol-3 kinase; Akt, protein kinase B; AMPK AMP-activated kinase; mTOR, mammalian target of rapamycin protein kinase; eIF4E, eukaryotic initiation factor 4E; 4E-BP1, eIF4E binding protein 1; S6K1; p70/p85 ribosomal protein S6 protein kinase; eIF4F, eukaryotic initiation factor 4F; S6, ribosomal protein S6; GSK-3, glycogen synthase kinase 3; eIF2B, eukaryotic initiation factor $2 \mathrm{~B}$; eIF2.GDP, inactive eukaryotic initiation factor 2; eIF2.GTP, activated eukaryotic initiation factor 2 .

Chapter 7 shows that a single session of high-intensity resistance exercise in vivo in humans significantly increases AMPK phosphorylation and reduces the phosphorylation status of 4E-BP1 in skeletal muscle tissue immediately after cessation of exercise. The exercise bout did not substantially increase S6 phosphorylation, indicating that $\mathrm{p} 70-\mathrm{S} 6 \mathrm{~K}$ activity was not increased to a large extent. Similar results were reported following resistance exercise in rats (14), and 
S6K1 phosphorylation at $\mathrm{Thr}^{389}$ was shown to be unchanged. Our observations are also in agreement with data reported by Karlsson et al. (38), showing that a single session of resistance exercise (4 sets, 10 repetitions of leg extension) does not fully activate p70-S6K. However, they showed that post-exercise ingestion of branched chain amino acids has a striking effect on p70-S6K, which was evident by sitespecific phosphorylation at $\mathrm{Thr}^{389}$ (38). These data indicate that intake of an ample amount of amino acids is essential to activate skeletal muscle translation initiation. Though translation initiation is likely to represent a main regulatory factor in modulating muscle protein synthesis, Proud and colleagues $(16,63)$ have shown that also the translation elongation process is under regulatory control by nutrients and hormones. The latter suggests that the anabolic response to exercise and/or nutrient intake can be controlled at various different levels (i.e. mRNA translation initiation, elongation, termination and post-translational modification). The relationship between activation of the molecular signaling pathways and in vivo muscle protein synthesis rates in response to exercise and nutrition clearly remains to be assessed in vivo in human studies.

In chapter 5 and 6 we investigated the effect of post-exercise intake of carbohydrate, protein and free leucine and showed that muscle protein synthesis rates were substantially increased when leucine was co-ingested with protein and carbohydrate when compared with the ingestion of carbohydrate only. Although these studies do not demonstrate that leucine specifically stimulates muscle protein synthesis in vivo in humans following resistance exercise/ADL activities, it demonstrates that protein anabolism following resistance exercise can be augmented with the ingestion of a leucine, protein and carbohydrate mixture. Studies in rats have increased the understanding of the mechanisms of nutritional regulation of protein synthesis at the molecular level and indicate that leucine ingestion could stimulate muscle anabolism in several ways, as it can further increase plasma insulin concentrations and also directly stimulate protein synthesis in an insulin independent manner. The stimulatory effect of leucine on protein synthesis occurs at the level of translation initiation and involves signaling through mTOR (41, 62), and subsequent phosphorylation and activation of 4E-BP1, S6K1 and ribosomal protein S6 (figure 8.2). The protein kinase mTOR is thought to serve as a convergence point for leucine- and insulin-mediated effects on translation initiation $(41,62)$. Furthermore, leucine has been shown to have the potential to affect muscle protein metabolism by decreasing the rate of protein degradation (54), most likely via an increase in circulating insulin (38, 48, 62). However, not only leucine has the potential to stimulate muscle protein synthesis, as intramuscular and plasma essential amino acid availability has been shown to play an important regulatory role in protein anabolism $(12,92)$. In addition to increased signaling through mTOR, an increase in essential amino acid availability results in a decreased phosphorylation of the eukaryotic initiation factor 2 (eIF2). The phosphorylation of the eIF2 ( $\alpha$-subunit) is mediated by the mammalian ortholog of the yeast general control nonderepressing kinase 2 (mGCN2), which responds to changes in (essential) amino acid availability. Decrease in phosphorylation of $\mathrm{eIF} 2 \alpha$ leads to the dissociation and activation of the eukaryotic 
initiation factor 2B (eIF2B), thereby increasing the translation of most mRNAs (Fig 2).

Data provided in chapters 4-6 in this thesis, show that the combination of exercise and nutrition can effectively stimulate (muscle) protein synthesis. There is an increasing body of evidence showing that the PI3-Kinase signaling pathway is likely to play a key role in the integration of contraction mediated signaling and signaling from nutritional factors. Most of the research has been performed using in vitro and in vivo animal models. In these models, exercise or electrical stimulation have been shown to increase signaling through the PI3-kinase/mTOR pathway resulting in increases in protein synthesis and glucose uptake. In addition to exercise, ingestion of amino acids, and leucine in particular, has been shown to effectively increase mTOR phosphorylation and the activation of translation. For now, there is no human data available to assess the proposed stimulating effects of leucine on skeletal muscle protein synthesis.

\section{General conclusions}

In this thesis, we focused on the beneficial effects of resistance exercise and the potential of dietary supplementation with carbohydrate, protein and leucine to enhance muscle protein anabolism. Resistance exercise was shown to be as powerful as endurance exercise in enhancing post-exercise insulin sensitivity. In addition, we reported that a single resistance exercise session substantially reduced intramyocellular glycogen content in a muscle fiber-type specific manner. The latter suggests that the acute improvements in whole-body insulin sensitivity following resistance exercise could, at least partly, be attributed to the net reduction in skeletal muscle glycogen content. Additionally, we showed that immediately after resistance exercise AMPK phosphorylation is increased. This could be the initial trigger to increase glucose uptake and to simultaneously inhibit mRNA translation initiation (and thus protein synthesis). Although S6K1 phosphorylation was increased in a muscle fiber-type specific manner following resistance exercise, the phosphorylation of S6 was not substantially increased under fasting conditions.

As such, in the absence of food intake, exercise does not fully activate the translation initiation process in skeletal muscle tissue. Therefore, the combined ingestion of protein and carbohydrate has been suggested as a more effective strategy to promote net muscle protein accretion, as it can stimulate protein metabolism by providing amino acids as precursors for protein synthesis and further elevate plasma insulin levels and reduce protein breakdown. We showed that prolonged exhaustive moderate intensity endurance exercise does not result in increased protein degradation and/or a decrease in protein synthesis compared with resting situations when carbohydrates are ingested. However, protein intake is necessary to increase protein synthesis and further decrease protein breakdown, resulting in a positive net protein balance.

Amino acids have more metabolic roles than to merely serve as building blocks for proteins. They function as potent nutritional signaling molecules, and have an 
active regulatory role in modulating muscle protein metabolism. The branchedchain amino acid leucine seems to have the potential to promote protein anabolism. Despite many speculations and promising results from recent animal studies, there is hardly any evidence showing leucine supplementation to improve protein balance in vivo in humans. Therefore, we investigated the effect of postexercise intake of leucine and showed that muscle protein synthesis rates were substantially increased when leucine was co-ingested with protein and carbohydrate compared with the ingestion of carbohydrate only.

These observations have lead to the hypothesis that physical activity followed by the ingestion of leucine with protein and carbohydrate could represent an effective strategy to reduce or counteract the loss of muscle tissue that occurs with aging. Consequently, we demonstrated that co-ingestion of protein and leucine with carbohydrate improves whole-body protein balance when compared with the ingestion of carbohydrate only in young and elderly men. Mixed muscle protein synthesis was shown to be reduced in the elderly when only carbohydrate was ingested. However, co-ingestion of protein and leucine substantially increases mixed muscle protein synthesis rates to the same level in the young and elderly, thereby improving whole-body protein balance. The present data indicate that the combined ingestion of carbohydrate, protein and leucine represents an effective strategy to increase muscle anabolism following resistance exercise or ADL activities in young and elderly humans.

\section{Future research}

The studies described in this thesis provide novel information on the beneficial effects of resistance exercise and the use of dietary supplements containing carbohydrate, protein and/or leucine as means to optimize post-exercise muscle protein anabolism in vivo in humans. However, there are many questions that still need to be addressed in future research:

* Is the combined ingestion of leucine and protein with carbohydrate more effective in stimulating protein synthesis compared to carbohydrate and protein ingestion only?

* Is phenylalanine converted to tyrosine in human skeletal muscle?

* Which proteins are synthesized at a higher rate following exercise and are there differences in the specific sets of proteins that are synthesized after resistance and endurance exercise as well as between young and elderly humans?

* What is the effect of protein ingestion following exercise on the specific sets of proteins that are synthesized and are there differences between young and elderly humans?

* Do different types of proteins differ in ability to stimulate muscle protein anabolism?

* What is the relationship between the activation of intracellular signaling and in vivo muscle protein synthesis? 
* What signaling pathways that regulate muscle protein synthesis are impaired in the elderly?

* What is the time course of activation of the key kinases leading to protein anabolism and remodeling and does the activation window depend on the timing of nutrient intake and composition? 


\section{References}

1. Ahlborg G, Felig P, Hagenfeldt L, Hendler R, and Wahren J. Substrate turnover during prolonged exercise in man. Splanchnic and leg metabolism of glucose, free fatty acids, and amino acids. J Clin Invest 53: 1080-1090, 1974.

2. Anthony JC, Anthony TG, Kimball SR, Vary TC, and Jefferson LS. Orally administered leucine stimulates protein synthesis in skeletal muscle of postabsorptive rats in association with increased eIF4F formation. J Nutr 130: 139-145, 2000.

3. Anthony JC, Reiter AK, Anthony TG, Crozier SJ, Lang CH, MacLean DA, Kimball SR, and Jefferson LS. Orally Administered Leucine Enhances Protein Synthesis in Skeletal Muscle of Diabetic Rats in the Absence of Increases in 4E-BP1 or S6K1 Phosphorylation. Diabetes 51: 928-936, 2002.

4. Anthony JC, Yoshizawa F, Anthony TG, Vary TC, Jefferson LS, and Kimball SR. Leucine stimulates translation initiation in skeletal muscle of postabsorptive rats via a rapamycin-sensitive pathway. J Nutr 130: 2413-2419, 2000.

5. Baar K and Esser K. Phosphorylation of p70(S6k) correlates with increased skeletal muscle mass following resistance exercise. Am J Physiol 276: C120-127, 1999.

6. Biolo G, Declan Fleming RY, and Wolfe RR. Physiologic hyperinsulinemia stimulates protein synthesis and enhances transport of selected amino acids in human skeletal muscle. J Clin Invest 95: 811-819, 1995.

7. Biolo G, Fleming RY, Maggi SP, and Wolfe RR. Transmembrane transport and intracellular kinetics of amino acids in human skeletal muscle. Am J Physiol 268: E7584, 1995.

8. Biolo G, Maggi SP, Williams BD, Tipton KD, and Wolfe RR. Increased rates of muscle protein turnover and amino acid transport after resistance exercise in humans. Am J Physiol 268: E514-520, 1995.

9. Biolo G, Tipton KD, Klein S, and Wolfe RR. An abundant supply of amino acids enhances the metabolic effect of exercise on muscle protein. Am J Physiol 273: E122129, 1997.

10. Biolo G, Williams BD, Fleming RY, and Wolfe RR. Insulin action on muscle protein kinetics and amino acid transport during recovery after resistance exercise. Diabetes 48: 949-957, 1999.

11. Bogardus C, Thuillez P, Ravussin E, Vasquez B, Narimiga M, and Azhar S. Effect of muscle glycogen depletion on in vivo insulin action in man. J Clin Invest 72: 1605-1610, 1983.

12. Bohe J, Low A, Wolfe RR, and Rennie MJ. Human muscle protein synthesis is modulated by extracellular, not intramuscular amino acid availability: a dose-response study. J Physiol 552: 315-324, 2003.

13. Bolster DR, Crozier SJ, Kimball SR, and Jefferson LS. AMP-activated protein kinase suppresses protein synthesis in rat skeletal muscle through downregulated mTOR signaling. J Biol Chem 277: 23977-23980, 2002.

14. Bolster DR, Kubica N, Crozier SJ, Williamson DL, Farrell PA, Kimball SR, and Jefferson LS. Immediate response of mammalian target of rapamycin (mTOR)mediated signalling following acute resistance exercise in rat skeletal muscle. J Physiol 553: 213-220, 2003.

15. Borsheim E, Tipton KD, Wolf SE, and Wolfe RR. Essential amino acids and muscle protein recovery from resistance exercise. Am J Physiol Endocrinol Metab 283: E648657, 2002. 
16. Browne GJ and Proud CG. Regulation of peptide-chain elongation in mammalian cells. Eur J Biochem 269: 5360-5368, 2002.

17. Buse MG and Reid SS. Leucine. A possible regulator of protein turnover in muscle. J Clin Invest 56: 1250-1261, 1975.

18. Cauza E, Hanusch-Enserer U, Strasser B, Ludvik B, Metz-Schimmerl S, Pacini G, Wagner O, Georg P, Prager R, Kostner K, Dunky A, and Haber P. The relative benefits of endurance and strength training on the metabolic factors and muscle function of people with type 2 diabetes mellitus. Arch Phys Med Rehabil 86: 1527$1533,2005$.

19. Chang TW and Goldberg AL. The origin of alanine produced in skeletal muscle. J Biol Chem 253: 3677-3684, 1978.

20. Chen ZP, Stephens TJ, Murthy S, Canny BJ, Hargreaves M, Witters LA, Kemp BE, and McConell GK. Effect of exercise intensity on skeletal muscle AMPK signaling in humans. Diabetes 52: 2205-2212, 2003.

21. Cheng SW, Fryer LG, Carling D, and Shepherd PR. Thr2446 is a novel mammalian target of rapamycin (mTOR) phosphorylation site regulated by nutrient status. J Biol Chem 279: 15719-15722, 2004.

22. Chin ER. Role of $\mathrm{Ca} 2+/$ calmodulin-dependent kinases in skeletal muscle plasticity. J Appl Physiol 99: 414-423, 2005.

23. Derave W, Hansen BF, Lund S, Kristiansen S, and Richter EA. Muscle glycogen content affects insulin-stimulated glucose transport and protein kinase B activity. Am J Physiol Endocrinol Metab 279: E947-955, 2000.

24. Essen-Gustavsson B and Tesch PA. Glycogen and triglyceride utilization in relation to muscle metabolic characteristics in men performing heavy-resistance exercise. Eur J Appl Physiol Occup Physiol 61: 5-10, 1990.

25. Farrell PA, Fedele MJ, Hernandez J, Fluckey JD, Miller JL, 3rd, Lang CH, Vary TC, Kimball SR, and Jefferson LS. Hypertrophy of skeletal muscle in diabetic rats in response to chronic resistance exercise. J Appl Physiol 87: 1075-1082, 1999.

26. Fisher JS, Gao J, Han DH, Holloszy JO, and Nolte LA. Activation of AMP kinase enhances sensitivity of muscle glucose transport to insulin. Am J Physiol Endocrinol Metab 282: E18-23, 2002.

27. Fryburg DA, Jahn LA, Hill SA, Oliveras DM, and Barrett EJ. Insulin and insulin-like growth factor-I enhance human skeletal muscle protein anabolism during hyperaminoacidemia by different mechanisms. J Clin Invest 96: 1722-1729, 1995.

28. Fryer LG, Foufelle F, Barnes K, Baldwin SA, Woods A, and Carling D. Characterization of the role of the AMP-activated protein kinase in the stimulation of glucose transport in skeletal muscle cells. Biochem J 363: 167-174, 2002.

29. Garcia-Roves PM, Han DH, Song Z, Jones TE, Hucker KA, and Holloszy JO. Prevention of glycogen supercompensation prolongs the increase in muscle GLUT4 after exercise. Am J Physiol Endocrinol Metab 285: E729-736, 2003.

30. Garlick PJ and Grant I. Amino acid infusion increases the sensitivity of muscle protein synthesis in vivo to insulin. Effect of branched-chain amino acids. Biochem J 254: 579584, 1988.

31. Gelfand RA and Barrett EJ. Effect of physiologic hyperinsulinemia on skeletal muscle protein synthesis and breakdown in man. J Clin Invest 80: 1-6, 1987.

32. Gore DC, Wolf SE, Sanford AP, Herndon DN, and Wolfe RR. Extremity hyperinsulinemia stimulates muscle protein synthesis in severely injured patients. Am J Physiol Endocrinol Metab 286: E529-534, 2004. 
33. Hameed M, Orrell RW, Cobbold M, Goldspink G, and Harridge SD. Expression of IGF-I splice variants in young and old human skeletal muscle after high resistance exercise. J Physiol 547: 247-254, 2003.

34. Hasten DL, Pak-Loduca J, Obert KA, and Yarasheski KE. Resistance exercise acutely increases MHC and mixed muscle protein synthesis rates in 78-84 and 23-32 yr olds. Am J Physiol Endocrinol Metab 278: E620-626, 2000.

35. Hayashi T, Hirshman MF, Fujii N, Habinowski SA, Witters LA, and Goodyear LJ. Metabolic stress and altered glucose transport: activation of AMP-activated protein kinase as a unifying coupling mechanism. Diabetes 49: 527-531, 2000.

36. Hernandez JM, Fedele MJ, and Farrell PA. Time course evaluation of protein synthesis and glucose uptake after acute resistance exercise in rats. J Appl Physiol 88: 1142-1149, 2000.

37. Howald H, Boesch C, Kreis R, Matter S, Billeter R, Essen-Gustavsson B, and Hoppeler H. Content of intramyocellular lipids derived by electron microscopy, biochemical assays, and (1)H-MR spectroscopy. J Appl Physiol 92: 2264-2272, 2002.

38. Karlsson HK, Nilsson PA, Nilsson J, Chibalin AV, Zierath JR, and Blomstrand E. Branched-Chain Amino Acids Increase p70S6 Kinase Phosphorylation in Human Skeletal Muscle after Resistance Exercise. Am J Physiol Endocrinol Metab 287:E1-7, 2004.

39. Keul J, Haralambie G, Bruder M, and Gottstein HJ. The effect of weight lifting exercise on heart rate and metabolism in experienced weight lifters. Med Sci Sports 10: 13-15, 1978.

40. Kimball SR, Farrell PA, and Jefferson LS. Invited Review: Role of insulin in translational control of protein synthesis in skeletal muscle by amino acids or exercise. J Appl Physiol 93: 1168-1180, 2002.

41. Kimball SR and Jefferson LS. Regulation of global and specific mRNA translation by oral administration of branched-chain amino acids. Biochem Biophys Res Commun 313: 423-427, 2004.

42. Koopman R, Pannemans DL, Jeukendrup AE, Gijsen A, Senden JMG, Halliday D, Saris WHM, van Loon LJC, and Wagenmakers AJM. The combined ingestion of protein and carbohydrate improves protein balance during ultra endurance exercise. Am J Physiol Endocrinol Metab 287: E712-720, 2004.

43. Koopman R, Schaart G, and Hesselink MK. Optimisation of oil red O staining permits combination with immunofluorescence and automated quantification of lipids. Histochem Cell Biol 116: 63-68, 2001.

44. Koopman R, Wagenmakers AJ, Manders RJ, Zorenc AH, Senden JM, Gorselink M, Keizer HA, and van Loon LJ. Combined ingestion of protein and free leucine with carbohydrate increases post-exercise muscle protein synthesis in vivo in male subjects. Am J Physiol Endocrinol Metab 288: E645-653, 2005.

45. Kraniou Y, Cameron-Smith D, Misso M, Collier G, and Hargreaves M. Effects of exercise on GLUT-4 and glycogenin gene expression in human skeletal muscle. J Appl Physiol 88: 794-796, 2000.

46. Kubica N, Bolster DR, Farrell PA, Kimball SR, and Jefferson LS. Resistance exercise increases muscle protein synthesis and translation of eukaryotic initiation factor 2Bepsilon mRNA in a mammalian target of rapamycin-dependent manner. $\mathrm{J}$ Biol Chem 280: 7570-7580, 2005.

47. Levenhagen DK, Carr C, Carlson MG, Maron DJ, Borel MJ, and Flakoll PJ. Postexercise protein intake enhances whole-body and leg protein accretion in humans. Med Sci Sports Exerc 34: 828-837, 2002. 
48. Liu Z, Jahn LA, Long W, Fryburg DA, Wei L, and Barrett EJ. Branched chain amino acids activate messenger ribonucleic acid translation regulatory proteins in human skeletal muscle, and glucocorticoids blunt this action. J Clin Endocrinol Metab 86: 2136-2143, 2001.

49. Matthews DE, Motil KJ, Rohrbaugh DK, Burke JF, Young VR, and Bier DM. Measurement of leucine metabolism in man from a primed, continuous infusion of L[1-3C]leucine. Am J Physiol 238: E473-479, 1980.

50. Matthews DE, Motil KJ, Rohrbaugh DK, Burke JF, Young VR, and Bier DM. Measurement of leucine metabolism in man from a primed, continuous infusion of L[1-13C]leucine. Am J Physiol 238: E473-479, 1980.

51. Mikines KJ, Sonne B, Farrell PA, Tronier B, and Galbo H. Effect of physical exercise on sensitivity and responsiveness to insulin in humans. Am J Physiol 254: E248-259, 1988.

52. Miller SL, Tipton KD, Chinkes DL, Wolf SE, and Wolfe RR. Independent and Combined Effects of Amino Acids and Glucose after Resistance Exercise. Med Sci Sports Exerc 35: 449-455, 2003.

53. Nair KS, Halliday D, and Griggs RC. Leucine incorporation into mixed skeletal muscle protein in humans. Am J Physiol 254: E208-213, 1988.

54. Nair KS, Schwartz RG, and Welle S. Leucine as a regulator of whole-body and skeletal muscle protein metabolism in humans. Am J Physiol 263: E928-934, 1992.

55. Nielsen JN, Derave W, Kristiansen S, Ralston E, Ploug T, and Richter EA. Glycogen synthase localization and activity in rat skeletal muscle is strongly dependent on glycogen content. J Physiol 531: 757-769, 2001.

56. Nielsen JN and Richter EA. Regulation of glycogen synthase in skeletal muscle during exercise. Acta Physiol Scand 178: 309-319, 2003.

57. Paddon-Jones D, Sheffield-Moore M, Zhang XJ, Volpi E, Wolf SE, Aarsland A, Ferrando AA, and Wolfe RR. Amino acid ingestion improves muscle protein synthesis in the young and elderly. Am J Physiol Endocrinol Metab 286: E321-328, 2004.

58. Parkington JD, Siebert AP, LeBrasseur NK, and Fielding RA. Differential activation of mTOR signaling by contractile activity in skeletal muscle. Am J Physiol Regul Integr Comp Physiol 285: R1086-1090, 2003.

59. Perseghin G, Price TB, Petersen KF, Roden M, Cline GW, Gerow K, Rothman DL, and Shulman GI. Increased glucose transport-phosphorylation and muscle glycogen synthesis after exercise training in insulin-resistant subjects. N Engl J Med 335: 13571362, 1996.

60. Phillips SM, Tipton KD, Aarsland A, Wolf SE, and Wolfe RR. Mixed muscle protein synthesis and breakdown after resistance exercise in humans. Am J Physiol 273: E99107, 1997.

61. Pitkanen HT, Nykanen T, Knuutinen J, Lahti K, Keinanen O, Alen M, Komi PV, and Mero AA. Free amino acid pool and muscle protein balance after resistance exercise. Med Sci Sports Exerc 35: 784-792, 2003.

62. Proud CG. mTOR-mediated regulation of translation factors by amino acids. Biochem Biophys Res Commun 313: 429-436, 2004.

63. Proud CG. Regulation of mammalian translation factors by nutrients. Eur J Biochem 269: 5338-5349, 2002.

64. Rasmussen BB, Tipton KD, Miller SL, Wolf SE, and Wolfe RR. An oral essential amino acid-carbohydrate supplement enhances muscle protein anabolism after resistance exercise. J Appl Physiol 88: 386-392, 2000. 
65. Rennie MJ, Edwards RH, Krywawych S, Davies CT, Halliday D, Waterlow JC, and Millward DJ. Effect of exercise on protein turnover in man. Clin Sci (Lond) 61: 627639, 1981.

66. Richter EA, Derave W, and Wojtaszewski JF. Glucose, exercise and insulin: emerging concepts. J Physiol 535: 313-322, 2001.

67. Roman WJ, Fleckenstein J, Stray-Gundersen J, Alway SE, Peshock R, and Gonyea WJ. Adaptations in the elbow flexors of elderly males after heavy-resistance training. J Appl Physiol 74: 750-754, 1993.

68. Rose AJ and Hargreaves M. Exercise increases Ca2+-calmodulin-dependent protein kinase II activity in human skeletal muscle. J Physiol 553: 303-309, 2003.

69. Roy BD, Tarnopolsky MA, MacDougall JD, Fowles J, and Yarasheski KE. Effect of glucose supplement timing on protein metabolism after resistance training. J Appl Physiol 82: 1882-1888, 1997.

70. Sakamoto K, Aschenbach WG, Hirshman MF, and Goodyear LJ. Akt signaling in skeletal muscle: regulation by exercise and passive stretch. Am J Physiol Endocrinol Metab 285: E1081-1088, 2003.

71. Sakamoto $\mathrm{K}$ and Goodyear LJ. Invited review: intracellular signaling in contracting skeletal muscle. J Appl Physiol 93: 369-383, 2002.

72. Salmons $S$ and Henriksson J. The adaptive response of skeletal muscle to increased use. Muscle Nerve 4: 94-105, 1981.

73. Salmons $S$ and Vrbova G. The influence of activity on some contractile characteristics of mammalian fast and slow muscles. J Physiol 201: 535-549, 1969.

74. Schaart G, Hesselink RP, Keizer HA, Van Kranenburg G, Drost MR, and Hesselink MK. A modified PAS stain combined with immunofluorescence for quantitative analyses of glycogen in muscle sections. Histochem Cell Biol 122: 161-169, 2004.

75. Short KR, Vittone JL, Bigelow ML, Proctor DN, and Nair KS. Age and aerobic exercise training effects on whole-body and muscle protein metabolism. Am J Physiol Endocrinol Metab 286: E92-101, 2004.

76. Tarnopolsky MA, Atkinson SA, MacDougall JD, Senor BB, Lemon PW, and Schwarcz H. Whole-body leucine metabolism during and after resistance exercise in fed humans. Med Sci Sports Exerc 23: 326-333, 1991.

77. Tesch PA, Colliander EB, and Kaiser P. Muscle metabolism during intense, heavyresistance exercise. Eur J Appl Physiol Occup Physiol 55: 362-366, 1986.

78. Thorell A, Hirshman MF, Nygren J, Jorfeldt L, Wojtaszewski JF, Dufresne SD, Horton ES, Ljungqvist O, and Goodyear LJ. Exercise and insulin cause GLUT-4 translocation in human skeletal muscle. Am J Physiol 277: E733-741, 1999.

79. Tipton KD, Ferrando AA, Phillips SM, Doyle D, Jr, and Wolfe RR. Post-exercise net protein synthesis in human muscle from orally administered amino acids. Am J Physiol 276: E628-634, 1999.

80. Tipton KD, Ferrando AA, Williams BD, and Wolfe RR. Muscle protein metabolism in female swimmers after a combination of resistance and endurance exercise. J Appl Physiol 81: 2034-2038, 1996.

81. Tipton KD, Rasmussen BB, Miller SL, Wolf SE, Owens-Stovall SK, Petrini BE, and Wolfe RR. Timing of amino acid-carbohydrate ingestion alters anabolic response of muscle to resistance exercise. Am J Physiol Endocrinol Metab 281: E197-206, 2001.

82. van Hall G, MacLean DA, Saltin B, and Wagenmakers AJ. Mechanisms of activation of muscle branched-chain alpha-keto acid dehydrogenase during exercise in man. $\mathrm{J}$ Physiol 494: 899-905, 1996. 
83. Van Hall G, Saltin B, and Wagenmakers AJ. Muscle protein degradation and amino acid metabolism during prolonged knee-extensor exercise in humans. Clin Sci (Lond) 97: 557-567, 1999.

84. van Loon LJ and Goodpaster BH. Increased intramuscular lipid storage in the insulinresistant and endurance-trained state. Pflugers Arch, 2005.

85. van Loon LJ, Koopman R, Manders R, van der Weegen W, van Kranenburg GP, and Keizer HA. Intramyocellular lipid content in type 2 diabetes patients compared with overweight sedentary men and highly trained endurance athletes. Am J Physiol Endocrinol Metab 287: E558-565, 2004.

86. van Loon LJ, Koopman R, Stegen JH, Wagenmakers AJ, Keizer HA, and Saris WH. Intramyocellular lipids form an important substrate source during moderate intensity exercise in endurance-trained males in a fasted state. J Physiol 553: 611-625, 2003.

87. van Loon LJ, Manders RJ, Koopman R, Kaastra B, Stegen JH, Gijsen AP, Saris WH, and Keizer HA. Inhibition of adipose tissue lipolysis increases intramuscular lipid use in type 2 diabetic patients. Diabetologia, 2005.

88. van Loon LJ, Saris WH, Verhagen H, and Wagenmakers AJ. Plasma insulin responses after ingestion of different amino acid or protein mixtures with carbohydrate. Am J Clin Nutr 72: 96-105, 2000.

89. Van Loon LJ, Schrauwen-Hinderling VB, Koopman R, Wagenmakers AJ, Hesselink MK, Schaart G, Kooi ME, and Saris WH. Influence of prolonged endurance cycling and recovery diet on intramuscular triglyceride content in trained males. Am J Physiol Endocrinol Metab 285: E804-811, 2003.

90. van Loon LJ, Thomason-Hughes M, Constantin-Teodosiu D, Koopman R, Greenhaff PL, Hardie DG, Keizer HA, Saris WH, and Wagenmakers AJ. Inhibition of adipose tissue lipolysis increases intramuscular lipid and glycogen use in vivo in humans. Am J Physiol Endocrinol Metab 289: E482-493, 2005.

91. Volpi E, Ferrando AA, Yeckel CW, Tipton KD, and Wolfe RR. Exogenous amino acids stimulate net muscle protein synthesis in the elderly. J Clin Invest 101: 20002007, 1998.

92. Volpi E, Kobayashi H, Sheffield-Moore M, Mittendorfer B, and Wolfe RR. Essential amino acids are primarily responsible for the amino acid stimulation of muscle protein anabolism in healthy elderly adults. Am J Clin Nutr 78: 250-258, 2003.

93. Volpi E, Mittendorfer B, Rasmussen BB, and Wolfe RR. The response of muscle protein anabolism to combined hyperaminoacidemia and glucose-induced hyperinsulinemia is impaired in the elderly. J Clin Endocrinol Metab 85: 4481-4490, 2000.

94. Volpi E, Mittendorfer B, Wolf SE, and Wolfe RR. Oral amino acids stimulate muscle protein anabolism in the elderly despite higher first-pass splanchnic extraction. Am J Physiol 277: E513-520, 1999.

95. Volpi E, Sheffield-Moore M, Rasmussen BB, and Wolfe RR. Basal muscle amino acid kinetics and protein synthesis in healthy young and older men. Jama 286: 1206-1212, 2001.

96. Wagenmakers AJ. Tracers to investigate protein and amino acid metabolism in human subjects. Proc Nutr Soc 58: 987-1000, 1999.

97. Wagenmakers AJ, Beckers EJ, Brouns F, Kuipers H, Soeters PB, van der Vusse GJ, and Saris WH. Carbohydrate supplementation, glycogen depletion, and amino acid metabolism during exercise. Am J Physiol 260: E883-890, 1991.

98. Wagenmakers AJ, Brookes JH, Coakley JH, Reilly T, and Edwards RH. Exerciseinduced activation of the branched-chain 2-oxo acid dehydrogenase in human muscle. Eur J Appl Physiol Occup Physiol 59: 159-167, 1989. 
99. Welle S, Thornton C, and Statt M. Myofibrillar protein synthesis in young and old human subjects after three months of resistance training. Am J Physiol 268: E422-427, 1995.

100. Welle S, Thornton C, Statt M, and McHenry B. Postprandial myofibrillar and wholebody protein synthesis in young and old human subjects. Am J Physiol 267: E599-604, 1994.

101.Winder WW. Energy-sensing and signaling by AMP-activated protein kinase in skeletal muscle. J Appl Physiol 91: 1017-1028, 2001.

102. Wojtaszewski JF, Hansen BF, Gade, Kiens B, Markuns JF, Goodyear LJ, and Richter EA. Insulin signaling and insulin sensitivity after exercise in human skeletal muscle. Diabetes 49: 325-331, 2000.

103. Wojtaszewski JF, Hansen BF, Kiens B, and Richter EA. Insulin signaling in human skeletal muscle: time course and effect of exercise. Diabetes 46: 1775-1781, 1997.

104. Wojtaszewski JF, Jorgensen SB, Frosig C, MacDonald C, Birk JB, and Richter EA. Insulin signalling: effects of prior exercise. Acta Physiol Scand 178: 321-328, 2003.

105. Wolfe RR. Radioactive and stable isotope tracers in biomedicine: principles and practice of kinetic analysis. New York: Wiley-Liss, 1992.

106. Wolfe RR, Goodenough RD, Wolfe MH, Royle GT, and Nadel ER. Isotopic analysis of leucine and urea metabolism in exercising humans. J Appl Physiol 52: 458-466, 1982.

107. Wolfe RR, Wolfe MH, Nadel ER, and Shaw JH. Isotopic determination of amino acidurea interactions in exercise in humans. J Appl Physiol 56: 221-229, 1984.

108. Wright DC, Geiger PC, Holloszy JO, and Han DH. Contraction- and hypoxiastimulated glucose transport is mediated by a Ca2+-dependent mechanism in slowtwitch rat soleus muscle. Am J Physiol Endocrinol Metab 288: E1062-1066, 2005.

109. Wright DC, Hucker KA, Holloszy JO, and Han DH. Ca2+ and AMPK both mediate stimulation of glucose transport by muscle contractions. Diabetes 53: 330-335, 2004. 
Summary 
Skeletal muscle is one of the major organs involved in metabolism. Aging and chronic metabolic diseases, like type 2 diabetes, are generally associated with a significant loss of skeletal muscle mass. Muscle wasting eventually leads to muscle weakness and major disabilities in day-to-day life. Therefore, various interventions have been proposed to reduce or reverse the loss of muscle mass and function. Most attention so far was paid to endurance type of exercise. In this thesis we focus on the beneficial effects of resistance exercise and the proposed importance of the ingestion of carbohydrate, protein and/or specific amino acids as a means to augment muscle protein anabolism.

In chapter 2, we report that a single resistance exercise session can improve whole-body insulin sensitivity by as much as $15 \%$ when measured $24 \mathrm{~h}$ after cessation of exercise. The latter tends to be of a similar magnitude as the $\sim 20 \%$ improvement that has been reported in literature following an acute $(\sim 60 \mathrm{~min})$ bout of endurance exercise. The presented data indicate that there should be no restriction in combining the benefits of both types of exercise in future lifestyle intervention programs. The greater whole-body insulin sensitivity following endurance exercise has been associated with the reduction of muscle substrate sources following exercise. However, information on the metabolic demands of resistance exercise is scarce. In chapter $\mathbf{3}$, it is shown that mixed muscle glycogen content is substantially decreased following a single resistance exercise session. These changes in muscle glycogen are shown to be fiber-type specific, and tend to be more pronounced in type IIx muscle fibers compared to type I muscle fibers. Furthermore, intramyocellular lipid content is reduced in the type I muscle fibers only and returns to baseline values within $2 \mathrm{~h}$ of post-exercise recovery. The absence of a prolonged net reduction in skeletal muscle lipid content implies that the reported stimulating effects of resistance exercise on whole-body insulin sensitivity is unlikely to be attributed to a temporary reduction in intramyocellular lipid content.

In chapters 4, 5 and 6 the effects of exercise or activities of daily living and nutrition on protein metabolism are evaluated. In these studies, continuous infusions of labeled amino acids are applied to measure their rate of appearance and/or disappearance in blood. With this method we can estimate protein breakdown, synthesis, oxidation and net-balance on a whole-body level. In chapters $\mathbf{5}$ and $\mathbf{6}$ we also measure the rate of incorporation of a labeled amino acid into skeletal muscle protein to directly assess mixed muscle protein synthesis rates. In chapter 4, different tracer methods are compared with the intention to assess whole-body protein turnover, during and following $6 \mathrm{~h}$ of prolonged endurance exercise when carbohydrate or carbohydrate and protein are ingested. Discrepancies are shown when applying $\left[{ }^{2} \mathrm{H}_{5}\right]$ phenylalanine and/or $\left[{ }^{15} \mathrm{~N}\right]$ urea and the $\left[1-{ }^{13} \mathrm{C}\right]$ leucine tracer methods during exercise. These discrepancies are likely attributed to the fact that during exercise the uptake and oxidation of leucine is increased several fold. Therefore, leucine is likely not representative of the fate of the other essential amino acids during exercise. With phenylalanine and urea as tracers it is demonstrated that net protein degradation does not increase during moderate intensity exercise when carbohydrate is ingested. However, under these 
conditions, protein net balance remains negative. The combined ingestion of carbohydrate and protein is shown to improve net protein balance at rest, during exercise and post-exercise recovery.

In chapters 5 and $\mathbf{6}$ the effects of amino acid and/or protein (hydrolysate) ingestion on muscle protein synthesis are investigated. The combined ingestion of carbohydrate, protein and leucine stimulates protein anabolism in several ways. It provides amino acids as precursors for protein synthesis and elicits a strong insulinotropic response. In addition, in animal models, leucine has been shown to stimulate protein synthesis by an insulin-independent mechanism. In chapter 5, it

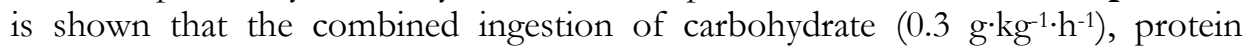

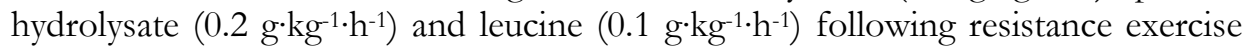
substantially augments the plasma insulin response. The combined ingestion of this mixture reduces whole-body protein breakdown and oxidation rates and increases protein synthesis rates. The net protein balance is negative when only carbohydrate is ingested, positive with carbohydrate and protein and improves further following the combined ingestion of carbohydrate, protein and leucine. In addition, muscle protein synthesis rates are shown to be significantly higher when carbohydrate, protein and leucine are ingested. These data suggest that the additional ingestion of free leucine in combination with protein and carbohydrate likely represents an effective strategy to increase muscle protein anabolism following resistance exercise.

The progressive loss of skeletal muscle mass with aging, or sarcopenia, is partly attributed to a disruption in the regulation of skeletal muscle protein turnover. The anabolic effect of food intake on muscle protein synthesis seems to be blunted in the elderly. The latter has been proposed to play a key-role in the etiology of sarcopenia. In chapter $\mathbf{6}$, potential differences in the response to the ingestion of

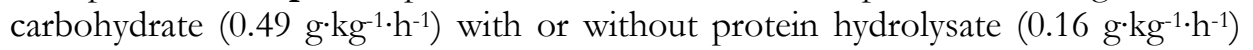
and free leucine $\left(0.03 \mathrm{~g} \cdot \mathrm{kg}^{-1} \cdot \mathrm{h}^{-1}\right)$ following simulated activities of daily living (ADL) on whole-body protein balance and mixed muscle protein synthesis rates are investigated in both young and elderly men. Whole-body phenylalanine and tyrosine fluxes are shown to be significantly higher in the young versus the elderly, indicative of a slower protein turnover rate in the elderly. Protein balance is shown to be negative when only carbohydrate is ingested, but positive when both protein and leucine are co-ingested in both groups. Muscle protein synthesis rates are shown to be substantially lower in elderly compared with young adults when only carbohydrates are ingested. Combined ingestion of protein hydrolysate and leucine with carbohydrate increases muscle protein synthesis rates and improves net protein balance to the same extent in young and elderly men. These data indicate that the anabolic properties of this nutritional intervention are equally effective in young and elderly men.

The rate of muscle protein synthesis is regulated in part by the process of mRNA translation initiation. The latter has been shown to be regulated by the posphatidylinositol 3 kinase signaling pathway, with major regulatory roles for the mammalian target of rapamycin (mTOR), S6 protein kinase 1 (S6K1) and the eukaryotic initiation factor 4E-binding protein (4E-BP1). In chapter 7, the effects 
of a single session of resistance exercise on the phosphorylation status of several proteins involved in the regulation of muscle protein synthesis are assessed. In addition, it is observed that changes in the phosphorylation status are muscle fibertype specific. Resistance exercise results in a strong activation of AMP activated kinase (AMPK), while 4E-BP1 phosphorylation is reduced, suggesting that translation initiation is blunted immediately following resistance exercise. During recovery, S6K1 phosphorylation increases but this is shown to occur predominantly in the fast twitch type II muscle fibers. The observation that S6 phosphorylation does not substantially change when subjects remain fasted implies that the ingestion of protein/amino acids is essential to fully activate the translational machinery.

In the final chapter, the significance and clinical relevance of the acquired data are discussed and important aims for future research are defined. In addition, specific methodological issues that need to be considered in future studies are also mentioned.

In summary, resistance exercise reduces muscle glycogen stores in a fiber-type specific manner, which could partly be responsible for the observed increase in insulin sensitivity following exercise. Although resistance exercise increases S6K1 phosphorylation in a fiber-type specific manner, S6 phosphorylation does not increase under fasting conditions. The latter indicates that food intake following exercise is needed to fully activate mRNA translation initiation and muscle protein synthesis. In contrast to common belief, endurance exercise does not increase protein degradation and oxidation when only carbohydrates are ingestion. However, the intake of protein/amino acids is necessary to attain a net positive protein balance. Amino acids do not only serve as building blocks for de novo protein synthesis. Amino acids, and leucine in particular, seem to be able to function as signaling molecules with an important regulatory role in muscle protein metabolism. The combined intake of leucine and protein hydrolysates with carbohydrate following resistance exercise can effectively stimulate muscle protein synthesis. These observations have lead to the hypothesis that physical activity followed by the ingestion of leucine with protein hydrolysate and carbohydrate could represent an effective strategy to reduce or counteract the loss of muscle tissue that occurs with aging. Co-ingestion of protein hydrolysate and leucine substantially increases mixed muscle protein synthesis rates to the same level in the young and elderly, thereby improving whole-body protein balance. The present data indicate that the combined ingestion of carbohydrate, protein and leucine represents an effective strategy to increase muscle protein anabolism following resistance exercise or ADL activities in young and elderly humans. 
Samenvatting 
De skeletspier is één van de belangrijkste organen die betrokken is bij de regulatie van het metabolisme. Veroudering en chronische metabole ziekten zoals diabetes zijn geassocieerd met een sterk verlies aan spiermassa. Dit heeft tot gevolg dat spierkracht en uithoudingsvermogen afneemt, waardoor de functionele capaciteit van de patiënt achteruit gaat. Om deze afname van de spiermassa tegen te gaan zijn verschillende interventies voorgesteld. Tot nu toe is er vooral aandacht geweest van de effecten van duurtrainingen. In dit proefschrift wordt aandacht besteed aan de voordelen van het uitvoeren van krachttraining en de mogelijkheden van de gecombineerde inname van koolhydraten, eiwithydrolysaten en leucine om de spieraanwas te stimuleren.

In hoofdstuk 2 wordt aangetoond dat de insuline gevoeligheid, 24 uur na één enkele krachttraining met ongeveer 15\% kan worden verbeterd. Dit is vergelijkbaar met de resultaten die gerapporteerd worden na het uitvoeren van één enkele duurtraining. De uitkomsten van deze studie geven dus aan dat er geen beperking behoeft te bestaan in het implementeren van beide vormen van inspanning in toekomstige interventieprogramma's. De verbeterde insuline gevoeligheid na inspanning wordt vaak geassocieerd met het gebruik van substraatvoorraden in de spier tijdens inspanning. Echter, er is eigenlijk nauwelijks iets bekend over hoeveel van die voorraden tijdens krachttraining gebruik wordt. In hoofdstuk 3 wordt aangetoond dat de spierglycogeen voorraad sterk gedaald is na een krachttrainingssessie. De verlaging in glycogeen voorraad blijkt daarnaast spiervezelspecifiek te zijn. De daling is namelijk groter in de snelle type IIx vezels in vergelijking met de langzamere type I vezels. Verder daalt ook de vetvoorraad in de spiervezels. Dit gebeurt echter selectief in de langzame vezels (type I) en 2 uur na inspanning is de vetvoorraad alweer angevuld tot basale hoeveelheden. Het feit dat de vetvoorraden in de spier na krachttraining niet verlaagd worden voor langere tijd, geeft aan dat de gerapporteerde toename in insuline gevoeligheid na dit soort inspanning niet kan worden toegeschreven aan een daling in vetvoorraden in de spier.

In de hoofdstukken 4, 5 en 6 zijn de effecten van fysieke inspanning en voedingsinterventies op het eiwitmetabolisme bestudeerd. In deze studies worden proefpersonen geïnfuseerd met gelabelde aminozuren. Op de wijze kan bepaald worden hoe snel aminozuren in het bloed verschijnen en hoe snel ze in weefsels verdwijnen. Met behulp van deze techniek kan op heel lichaamsniveau de eiwitaanmaak, afbraak, oxidatie en de netto balans uitgerekend worden. In hoofdstuk $\mathbf{5}$ en $\mathbf{6}$ is ook nog gemeten hoe snel het gelabelde aminozuur wordt ingebouwd in spierweefsel om op die manier de snelheid te kunnen bepalen waarmee spiereiwit wordt aangemaakt.

In hoofdstuk 4 worden verschillende gelabelde aminozuren (tracers) gebruikt om het eiwitmetabolisme voor, tijdens en na een 6 uur lange duurtraining in kaart te kunnen brengen terwijl de proefpersonen continue koolhydraten of koolhydraten en eiwitten innamen. Er bestaan duidelijke verschillen in de uitkomsten die verkregen zijn met de $\left[{ }^{2} \mathrm{H}_{5}\right]$ phenylalanine en $\left[{ }^{15} \mathrm{~N}\right]$ ureum tracer vergeleken met de $\left[1-{ }^{13}\right.$ C]leucine tracer tijdens inspanning. Dit verschil wordt waarschijnlijk veroorzaakt door het feit dat de leucine opname en oxidatie tijdens inspanning 
sterk verhoogd wordt, terwijl dat met andere aminozuren niet gebeurd. Hierdoor is leucine niet representatief voor het lot van de andere essentiële aminozuren tijdens inspanning. Met de phenylalanine en ureum tracers is aangetoond dat tijdens ultra lange duurinspanning de eiwitafbraak en oxidatie niet verhoogd is wanneer koolhydraten worden ingenomen gedurende de inspanning. Echter onder deze condities is de netto eiwitbalans negatief. Uit deze studie blijkt dat de inname van een koolhydraat en eiwitmengsel ervoor zorgt dat de netto eiwitbalans sterk positief wordt.

In de hoofdstukken $\mathbf{5}$ en $\mathbf{6}$ wordt het effect van de inname van eiwit/aminozuren op de spiereiwitsynthese bepaald. Deze inname van een mengsel met koolhydraten, eiwithydrolysaten en leucine kan op verschillende manieren de eiwitaanmaak stimuleren. Het levert bouwstenen (aminozuren) voor de aanmaak van eiwit en kan de insuline afgifte door de alvleesklier sterk verhogen. Verder blijkt uit dierenonderzoek dat het essentiële aminozuur leucine de unieke eigenschap heeft om direct de eiwitsynthese te stimuleren via een insuline onafhankelijk mechanisme. In hoofdstuk 5 wordt aangetoond dat de gecombineerde inname van koolhydraten $(0.3 \mathrm{~g} / \mathrm{kg} / \mathrm{u})$, eiwit $(0.2 \mathrm{~g} / \mathrm{kg} / \mathrm{u})$ en leucine $(0.1 \mathrm{~g} / \mathrm{kg} / \mathrm{u})$ na een krachttraining leidt tot een sterke stijging in de plasma insuline concentratie, wanneer deze wordt vergeleken met de inname van koolhydraat met of zonder eiwit. De eiwitafbraak en oxidatie wordt verlaagd terwijl de eiwitaanmaak wordt verhoogd na de inname van de koolhydraat, eiwit en leucine drank. De netto eiwitbalans op heel lichaamsniveau is negatief wanneer alleen koolhydraten worden ingenomen, positief wanneer eiwithydrolysaat aan de drank wordt toegevoegd en nog verder verhoogd wanneer ook leucine wordt toegevoegd. De spiereiwitsynthese is significant hoger wanneer koolhydraat, eiwithydrolysaat en leucine wordt ingenomen vergeleken met de inname van koolhydraten alleen. Deze data lijkt te suggereren dat de inname van eiwithydrolysaat en leucine met koolhydraten een effectieve strategie is om de spiereiwitaanmaak te verhogen na krachttraining.

Het verlies van spiermassa dat optreedt naarmate men ouder wordt, ook wel sarcopenie genoemd, wordt gedeeltelijk veroorzaakt door een verstoorde regulatie van de spiereiwitsynthese en afbraak. Bijvoorbeeld, het stimulerende effect van voedselinname op de spiereiwitsynthese lijkt bij ouderen verminderd te zijn. Dit wordt gezien als een van de belangrijkste factoren in de etiologie van sarcopenie. In hoofdstuk $\mathbf{6}$ wordt gekeken of er verschillen zijn in eiwit balans en spiereiwitsynthese na normale dagelijkse activiteiten met de inname van koolhydraten $(0.49 \mathrm{~g} / \mathrm{kg} / \mathrm{u})$ met of zonder eiwithydrolysaat $(0.16 \mathrm{~g} / \mathrm{kg} / \mathrm{u})$ en vrije leucine $(0.03 \mathrm{~g} / \mathrm{kg} / \mathrm{u})$ tussen oudere $( \pm 75$ jaar $)$ en jongere $( \pm 21$ jaar $)$ mensen. De flux van phenylalanine en tyrosine blijkt lager te zijn in de ouderen wat impliceert dat de eiwitturnover (aanmaak en afbraak) lager is in de oudere proefpersonen. Wanneer alleen koolhydraten worden ingenomen is de eiwitbalans op heellichaamsniveau negatief, terwijl hij positief is na de inname van leucine en eiwit met koolhydraten. De spiereiwitsynthese is significant lager in de oudere personen in vergelijking met de jongeren. De gecombineerde inname van eiwit en leucine met koolhydraten verhoogt de eiwitsynthese snelheid in zowel de jongeren als de 
ouderen. Sterker nog, de spiereiwitaanmaak wordt net zo sterk gestimuleerd door de inname van deze drank in de ouderen als in de jongeren. Dit betekent dat de anabole capaciteit van deze voedingsinterventie net zo groot is in ouderen als in jongeren.

De snelheid van spiereiwitaanmaak wordt gereguleerd door een proces genaamd translatie initiatie dat ervoor zorgt dat begonnen kan worden met het aflezen van mRNA en daarna eiwit gevormd kan worden. Dit proces wordt gereguleerd door de phophatidylinositol-3 kinase signaalcascade. De belangrijkste enzymen/kinases in deze keten zijn de proteïne kinase mTOR, S6 proteïne kinase 1 (S6K1) en eukaryotische initiatie factor 4E-bindingsproteïne (4E-BP1). In hoofdstuk 7 wordt het effect van één enkele krachttraining op de fosforylatiestatus van verschillende eiwitten gemeten die betrokken zijn in de regulatie van de spiereiwitsynthese snelheid. Het blijkt dat veranderingen in fosforylatie van S6K1 spiervezeltype afhankelijk zijn. Deze fosforylatie treedt vooral op in snelle type II spiervezels. De krachttraining resulteert in een sterke activering van de AMP geactiveerde kinase (AMPK), terwijl 4E-BP1 fosforylatie verlaagd is. Dit impliceert dat direct na inspanning translatie initiatie geremd is. Gedurende het herstel neemt de mate van S6K1 fosforylatie toe, terwijl de fosforylatie van S6 niet verandert wanneer proefpersonen nuchter blijven. Deze data suggereert dat de inname van voldoende eiwitten nodig is om de translatie initiatie optimaal te laten verlopen.

In het laatste hoofdstuk wordt het belang van de behaalde onderzoeksresultaten besproken en hun klinische relevantie voor de oudere populatie bediscussieerd. Verder worden belangrijke doelen voor toekomstig onderzoek gedefinieerd. Ook worden specifieke methodologische problemen waarmee rekening moet worden gehouden in toekomstig onderzoek aangehaald.

Samenvattend, krachttraining leidt tot een spiervezelspecifieke verlaging van de glycogeenvoorraad in de spier, wat gedeeltelijk verantwoordelijk is voor de verhoogde insuline gevoeligheid na inspanning. Hoewel krachttraining de fosforylatie van S6K1 verhoogt op een spiervezelspecifieke manier, blijft de fosforylatie van S6 onveranderd wanneer men gevast blijft. Dit geeft aan dat de inname van voedsel na het sporten essentieel is om de mRNA translatie initiatie en de aanmaak van spiereiwit volledig te activeren. Hoewel over het algemeen gedacht wordt dat duurtraining leidt tot een toegenomen eiwit afbraak en oxidatie, blijkt dit niet het geval te zijn wanneer koolhydraten worden ingenomen. Om een positieve netto eiwitbalans te verkrijgen moet men naast koolhydraten echter ook eiwitten/aminozuren innemen. Aminozuren vormen niet alleen de bouwstenen voor nieuwe eiwitten, ze kunnen ook functioneren als signaal moleculen die een belangrijke regulerende rol in het eiwitmetabolisme kunnen spelen. Dit geldt vooral voor het aminozuur leucine. De gecombineerde inname van leucine, eiwithydrolysaat en koolhydraten na een krachttraining blijkt effectief in het stimuleren van de spiereiwitsynthese. Deze observatie heeft tot de hypothese geleid dat fysieke activiteit gevolgd door de inname van leucine, eiwit en koolhydraten een effectieve strategie kan zijn om het verlies van spiermassa bij ouderen te verminderen of te voorkomen. Het blijkt dat de gecombineerde inname van 
leucine, eiwit en koolhydraten de spiereiwit-aanmaak in jongeren en ouderen in dezelfde mate stimuleert, wat leidt tot een verbeterde netto eiwit balans. Deze data geven aan dat de gecombineerde inname van leucine, eiwit en koolhydraten een effectieve strategie is om de spiereiwit-aanmaak te stimuleren in de eerste uren na een krachttraining of in de periode na een verhoogd dagelijkse activiteiten patroon in jonge en oudere mensen. 

Dankwoord 
Als allerlaatste schrijf ik nu dit dankwoord. Dit kleine stukje tekst zal waarschijnlijk toch het meest gelezen deel van dit proefschrift worden. Om een beetje op gang te komen zal ik maar beginnen met een enorm cliché: "Een proefschrift schrijven $\mathrm{kun} / \mathrm{kan} / \mathrm{ken}$ je niet alleen". Daarom wil ik iedereen bedanken die in de afgelopen jaren een bijdrage heeft geleverd. Een aantal mensen wil ik hierbij in het bijzonder benadrukken.

Allereerst wil ik natuurlijk Luc, mijn co-promotor, en Ton en Wim, mijn promotoren, bedanken. Luc, een betere begeleider dan jij kan een AIO zich niet wensen. Door jou is het voor mij mogelijk geweest om de afgelopen 4 jaar het maximale uit mezelf te halen. Door jou heb ik geleerd dat grenzen er zijn om overwonnen te worden (op naar de 170). Het uitgebreid met jou bediscussiëren van data en artikelopzetten heeft het schrijven voor mij een stuk makkelijker gemaakt. De zaken die me het meest bij zijn gebleven zijn natuurlijk allereerst, de tick dat ik voor, tijdens en na een testdag de neiging heb om alles 4 keer te controleren. Verder zijn de bemoedigende woorden: when does the hurting stop??? of natuurlijk at least things can't get any worse... gedenkwaardig. Het ziet er gelukkig naar uit dat we als team voorlopig nog even door kunnen blijven gaan. Ton, dank je voor het feit dat je mij de mogelijkheid hebt gegeven om AIO te worden. De vele uren met uitleg over de aminozuur-tracermethodologie zullen me bijblijven. Ik vond het jammer dat je naar B'ham vertrok, maar dit geeft natuurlijk wel de mogelijkheid voor extra buitenlandse reisjes! Wim, dankzij jou heb ik de studie uit 1996 kunnen opschrijven. Verder was je veelal op de achtergrond, maar je wist me te motiveren wanneer dat nodig was. Ik heb wel het idee dat we elkaar in de toekomst nog wel eens in een vergaderzaal zullen tegenkomen.

Further, I would like to thank all members of the reviewing committee, Arie Nieuwenhuijzen Kruseman, Yves Boirie, Arie Kies, Annemie Schols en Coen Stehouwer for their critical evaluation of my thesis. Kevin Tipton and Harm Kuipers, thank you for accepting the invitation to be part of the corona during my thesis defense.

Onder de bezielende begeleiding van Luc werk ik natuurlijk samen met verschillende werkpaarden uit de $\mathrm{M}^{3}$-groep (in wisselende samenstelling): Lex, Richard (macro-man), Joan, Antoine, Bart, Milou, Trent, Maurice, Hanneke en Stephan. Natuurlijk ook mijn 2 paranimfen Ralph en Kristof; dank jullie wel dat jullie mijn paranimfen willen zijn. Ralph, een betere collega en koffieleut kan een mens zich niet wensen, jouw levensmotto: it never hurts to help... Bedankt voor je hulp de afgelopen jaren! Kristof, al jaren zijn wij kamergenoten en wij hebben in de afgelopen tijd al veel kamergenoten versleten (Erwin, Kaatje, Hanneke, Githa en Anneke). In die tijd was je altijd het luisterende oor als er weer eens iets aan de hand was. Verder hebben mijn stagiaires Tjieu, Rudy, Marcel en Nico natuurlijk veel werk uit handen genomen waardoor ik me op het schrijven kon storten, jongens bedankt!!! Niet direct $\mathrm{M}^{3}$, maar Erik en Harm, dank jullie wel voor jullie support.

Zonder proefpersonen begin je als onderzoeker vrij weinig, of eigenlijk niks! Dus mannen, dank jullie wel dat ik bij jullie zoveel bloed en spierbiopten heb mogen verzamelen! In veel van mijn studies heb ik gebruik gemaakt van stabiele isotopen. 
Zonder de dames van het SIRC (Annemie, Anita, Hanne, Mia) en de mannen in de apotheek van het AZM (Eugene en Wil) waren de analyses/studies niet zo van de grond gekomen. Gert, bedankt voor de wijze lessen (samen met Matthijs) omtrent het Fingerspitzengefühl dat nodig is bij het uitvoeren van histochemische bepalingen. Jos en Wendy bedankt voor jullie inzet bij mijn verschillende studies qua analyses en Gabby voor het zetten van infusen. Ik heb ze eigenlijk nog nooit in een dankwoord terug zien komen, maar de mannen van de centrale sterilisatie/spoel-ruimte verdienen een bedankje voor het kunnen bijbenen van de snelheid waarmee ik in de afgelopen jaren bioptnaalden gebruikt heb.

Arie, Marian en Luc van DSM Food Specialties en Marchel en Ardy van Numico Research, bedankt voor onze (vaak urenlange) discussies over het project. Jullie hebben me een goede kijk gegeven over hoe mooi, maar soms ook hoe moeilijk het kan zijn om in de industrie te werken.

Samenwerkingen met andere labs zijn ook belangrijk en moeten daarom ook niet vergeten worden: Stephan en Thorsten (the Germans), Dominique en Dr Dendale (Hasselt), Hidde en Frits (AMC), Asker, Kevin, Chris and Carl (Birmingham), Olav (Stockholm) and David (Melbourne).

Yves and Stephane, I am looking forward to spend some time in ClermontFerrand next year.

Vrienden die collega's worden en andersom: Joost en Joris, buiten het werk, komen we elkaar vooral in de sportschool tegen waar jullie de sfeer altijd was losser weten te kriigen (ik weet niet of dit de prestaties altijd ten goede komt). Gijs, we zijn ongeveer gelijk begonnen aan het AIO-avontuur en zijn ook ongeveer gelijk klaar. Ik ben er dan ook trots op dat ik een kleine week na mijn eigen promotie, als paranimf achter je mag staan! Niels, trainingsbeest, bedankt voor alle fietstrainingstips, maar ik zal wel nooit een geweldige coureur worden. Dank ook aan alle overige collega's van Humane Biologie en Bewegingswetenschappen die het werken de afgelopen jaren aangenaam hebben gemaakt.

Bryan, mijn trainingsmaat, dank je voor je luisterend oor en voor het helpen bij alle laatste herhalingen zodat ik er nog net eentje extra kan doen.

Mijn familie, schoonfamilie en vrienden van boven de rivieren verdienen ook een bedankje. Pa en ma (of beter Kees en Elly), bedankt voor het feit dat jullie me hebben gestimuleerd te gaan studeren en voor getoonde steun en interesse gedurende de studie en het promoveertraject. Zie hier het resultaat! Monique en Marcel (en natuurlijk Ilan), onverwacht word ik toch ook nog een docent... Nico en Mariet, dank jullie wel voor Anouk en samen met Joyce en Guy voor de gezelligheid (en biertjes) de laatste jaren. Jaco, Wendy, Willem en Jacqueline, we zien elkaar te weinig, maar we zijn al jaren bezig om daar verandering in te brengen...

Tenslotte blijft er natuurlijk nog één persoon over, Anouk!!! Ik blijf het geweldig vinden je mijn vrouw te mogen noemen. Aan jou heb ik heel veel te danken. Je staat altijd voor me klaar en je geeft me de ruimte en tijd om uit te zoeken waar ik nu uiteindelijk naar toe wil. Mijn eeuwige dank voor al je liefde en geduld en ik hoop in de toekomst nog veel dingen met jou te mogen delen. 

Curriculum Vitae 
René Koopman was born on February 9th 1979 in Rotterdam, the Netherlands. In 1997, he completed his pre-university education at the Rijks Scholengemeenschap in Middelharnis. He started his study Health Sciences at Maastricht University in 1997. He graduated in the field of Movement Sciences in 2001 after an internship with Prof. Wagenmakers and Dr. van Loon at Maastricht University, after which he worked as a research assistant at the Department of Human Biology, Maastricht University. During this period he acquired practical experience with the use of (immuno)histochemical analyses.

In Februari 2002, he started as a $\mathrm{PhD}$ student at the department of Human Biology at Maastricht University. In 2005, he was awarded by the Nutrition Interest Group of the American College of Sports Medicine with the international research award for his work on nutritional interventions to promote post-exercise protein synthesis. In 2005 he was awarded with an International Training Fellowship Grant from the Nutricia Research Foundation to visit the Human Nutrition Laboratory (CRNH/INRA) in Clermont-Ferrand, France. There he will have the opportunity to acquire expertise in the use and application of molecular biology techniques and measurement of protein synthesis rates in different muscle protein fractions.

René Koopman is now appointed as a staff member at the Department of Movement Sciences. He continues his work on the stimulation of protein anabolism in the young and elderly by nutrition. Changes in protein metabolism are investigated on a whole-body, tissue and cellular level, with skeletal muscle as the main tissue of interest using a combination of stable isotope methodology, immuno-histochemistry and molecular biology methods. 
List of publications 
Koopman R, Schaart G and Hesselink MK. Optimisation of oil red O staining permits combination with immunofluorescence and automated quantification of lipids. Histochem Cell Biol (2001). 116(1): 63-8.

van Loon LJ, Koopman R, Stegen JH, Wagenmakers AJ, Keizer HA and Saris WH. Intramyocellular lipids form an important substrate source during moderate intensity exercise in endurance-trained males in a fasted state. J Physiol (2003). 553(Pt 2): 611-25.

Schrauwen-Hinderling VB, van Loon LJ, Koopman R, Nicolay K, Saris WH and Kooi ME. Intramyocellular lipid content is increased after exercise in nonexercising human skeletal muscle. J Appl Physiol (2003). 95(6): 2328-32.

van Loon LJ, Schrauwen-Hinderling VB, Koopman R, Wagenmakers AJ, Hesselink MK, Schaart G, Kooi ME and Saris WH. Influence of prolonged endurance cycling and recovery diet on intramuscular triglyceride content in trained males. Am J Physiol Endocrinol Metab (2003). 285(4): E804-11.

van Loon LJ, Koopman R, Schrauwen P, Stegen J and Wagenmakers AJ. The use of the [1,2-13C]acetate recovery factor in metabolic research. Eur J Appl Physiol (2003). 89(3-4): 377-83.

Koopman R, Pannemans DL, Jeukendrup AE, Gijsen AP, Senden JM, Halliday D, Saris WH, van Loon LJ and Wagenmakers AJ. Combined ingestion of protein and carbohydrate improves protein balance during ultra-endurance exercise. Am J Physiol Endocrinol Metab (2004). 287(4): E712-20.

van Loon LJ, Koopman R, Manders R, van der Weegen W, van Kranenburg GP and Keizer HA. Intramyocellular lipid content in type 2 diabetes patients compared with overweight sedentary men and highly trained endurance athletes. Am J Physiol Endocrinol Metab (2004). 287(3): E558-65.

Manders RJ, Wagenmakers AJ, Koopman R, Zorenc AH, Menheere PP, Schaper NC, Saris WH and van Loon LJ. Co-ingestion of a protein hydrolysate and amino acid mixture with carbohydrate improves plasma glucose disposal in patients with type 2 diabetes. Am J Clin Nutr (2005). 82(1): 76-83.

van Loon LJ, Thomason-Hughes M, Constantin-Teodosiu D, Koopman R, Greenhaff PL, Hardie DG, Keizer HA, Saris WH and Wagenmakers AJ. Inhibition of adipose tissue lipolysis increases intramuscular lipid and glycogen use in vivo in humans. Am J Physiol Endocrinol Metab (2005). 289(3): E482-93.

Koopman R, Manders RJ, Zorenc AH, Hul GB, Kuipers H, Keizer HA and van Loon LJ. A single session of resistance exercise enhances insulin sensitivity for at least 24h in healthy men. Eur J Appl Physiol (2005). 94(1-2): 180-7. 
Punyadeera C, Zorenc AH, Koopman R, McAinch AJ, Smit E, Manders R, Keizer HA, Cameron-Smith D and van Loon LJ. The effects of exercise and adipose tissue lipolysis on plasma adiponectin concentration and adiponectin receptor expression in human skeletal muscle. Eur J Endocrinol (2005). 152(3): 427-36.

Koopman R, Wagenmakers AJ, Manders RJ, Zorenc AH, Senden JM, Gorselink M, Keizer HA and van Loon LJ. Combined ingestion of protein and free leucine with carbohydrate increases post-exercise muscle protein synthesis in vivo in male subjects. Am J Physiol Endocrinol Metab (2005). 288(4): E645-53.

van Loon LJ, Manders RJ, Koopman R, Kaastra B, Stegen JH, Gijsen AP, Saris $\mathrm{WH}$ and Keizer HA. Inhibition of adipose tissue lipolysis increases intramuscular lipid use in type 2 diabetic patients. Diabetologia (2005). 48(10): 2097-107.

Koopman R, Manders RJ, Jonkers RA, Hul GB, Kuipers H and van Loon LJ. Intramyocellular lipid and glycogen content are reduced following resistance exercise in healthy males. Eur J Appl Physiol (2006). 96(5): 525-34.

Koopman R, Zorenc AH, Gransier R, Jonkers RA, Pelsers MA and van Loon LJ. The increase in p70-S6K phosphorylation immediately after resistance exercise is muscle fiber-type specific. Am J Physiol Endocrinol Metab (in press, 2006).

Manders RJ, Koopman R, Sluijsmans WE, van den Berg R, Verbeek K, Saris WH, Wagenmakers AJ and van Loon LJ. Co-ingestion of a protein hydrolysate with or without additional leucine reduces post-pracdial blood glucose excursions in type 2 diabetic men. J Nutr (in press, 2006).

Koopman R, Verdijk L, Manders RJ, Gijsen AP, Gorselink M, Pijpers E, Wagenmakers AJ and van Loon LJ. Co-ingestion of protein and leucine stimulates muscle protein synthesis rates to the same extent in young and elderly men. Am J Clin Nutr (submitted, 2005). 